UNIVERSIDADE DE SÃO PAULO

FACULDADE DE FILOSOFIA, LETRAS E CIÊNCIAS HUMANAS

DEPARTAMENTO DE SOCIOLOGIA

PROGRAMA DE PÓS-GRADUAÇÃO EM SOCIOLOGIA

\title{
WATARU KIKUCHI
}

Relações Hierárquicas do Japão Contemporâneo: um estudo da consciência de hierarquia na sociedade japonesa

Versão Revisada

São Paulo

2012 


\section{UNIVERSIDADE DE SÃO PAULO \\ FACULDADE DE FILOSOFIA, LETRAS E CIÊNCIAS HUMANAS \\ DEPARTAMENTO DE SOCIOLOGIA \\ PROGRAMA DE PÓS-GRADUAÇÃO EM SOCIOLOGIA}

Relações Hierárquicas do Japão Contemporâneo: um estudo da consciência de hierarquia na sociedade japonesa

Versão Revisada

Wataru Kikuchi

Tese apresentada ao Programa de Pós-Graduação em Sociologia, do Departamento de Sociologia da Faculdade de Filosofia, Letras e Ciências Humanas da Universidade de São Paulo, para obtenção do título de doutor em Sociologia.

Orientador: Prof. Dr. Mario Antonio Eufrásio

São Paulo

2012 


\section{Apresentação}

Esta tese foi desenvolvida no Programa de Pós-Graduação em Sociologia da Faculdade de Filosofia, Letras e Ciências Humanas da Universidade de São Paulo, com o objetivo de obtenção do título de doutor, sob orientação do Prof. Dr. Mario Antonio Eufrásio, no quadriênio 2008-2012. 
KEYWORDS: Japanese society; hierarchy; social structure; stratification; senpai and kohai.

ABSTRACT: The subject of this work is the hierarchic aspects in contemporary Japanese society. Starting from the contributions of classic authors like Ruth Benedict and Nakane Chie, this thesis aims at providing a description and an analysis of Japanese social relations. The approach is based on structuration theory, laying mainly on the conception of discursive consciousness. For such a purpose, the Japanese family, the school, the enterprise, the relation senpai-kohai ("senior-junior"), as relations with the concepts of social class and stratification are focused. The conclusion is that the relation senpai-kohai is the major reference and also that the family have lost its importance to the definition of hierarchy in Japan society.

PALAVRAS-CHAVE: Sociedade japonesa; hierarquia; estrutura social; estratificação; senpai e kohai.

RESUMO: O tema deste trabalho é a hierarquia na sociedade japonesa contemporânea. Partindo de contribuições de autores clássicos como Ruth Benedict e Nakane Chie, a presente tese pretende fornecer uma descrição e análise das relações sociais japonesas. A análise é embasada na teoria da estruturação, principalmente na concepção de consciência discursiva. Para tanto, a família, a escola, as empresas japonesas, a relação senpai-kohai ("veterano-novato"), assim como relações com a classe social e a estratificação são enfocadas. A conclusão é a de que a relação senpai-kohai é a principal referência, e também que a família tem perdido a importância para definição da hierarquia na sociedade Japonesa. 


\section{Agradecimentos}

Embora escrever uma tese seja, na essência, uma tarefa de responsabilidade individual, uma batalha solitária nesse sentido, ela não pode ser concretizada sem o apoio de inúmeras pessoas, e se quiser fazer justiça homenageando a todos numa lista, extensa será esta. E se tentar privilegiar alguns numa versão limitada, provavelmente cometerei a injustiça de deixar de citar alguns nomes. Mesmo correndo esse risco, devo registrar meus sinceros agradecimentos aos que seguem.

Em primeiro lugar, ao meu orientador prof. Mario Antonio Eufrásio, pela acolhida no Programa de Pós-Graduação em Sociologia, e pela sempre solícita e atenciosa orientação ao longo de quatro anos, acrescentando que sempre tive toda liberdade no encaminhamento da pesquisa, nas decisões a tomar e na escolha do rumo a seguir, de modo que eventuais faltas e desvios são de total responsabilidade minha. Se consegui concluir o trabalho no meio de idas e vindas, desaparecimentos momentâneos e de falta de notícias, devo à sua paciência e generosidade.

Aos professores Sedi Hirano e Tae Suzuki, pelos apontamentos feitos na banca de qualificação, que serviram para corrigir e reorientar a pesquisa, de modo que o produto final talvez tenha pouco vestígio daquele projeto. Entretanto, se fui certeiro no novo rumo, somente o tempo dirá. Devo agradecer também aos professores do Programa de Pós-Graduação em Sociologia, de quem tive a experiência ímpar de ser aluno e receber os ensinamentos.

Registro também minhas saudações aos colegas da Área de Língua e Literatura Japonesa do Departamento de Letras Orientais da FFLCH. Aos professores Junko Ota e Koichi Mori, respectivamente ex-diretora e atual diretor do Centro de Estudos 
Japoneses da USP, que sempre me apoiaram na condição de executivos dessa renomada instituição de pesquisa. Às professoras Eliza, Leiko, Lica, Madalena, Nana e Neide. Se consegui colocar um ponto final na minha tese, conciliando a elaboração dela ao longo desses quatro anos com a atividade docente de oito horas semanais, às vezes doze, e ainda com a organização da revista científica da área, a coordenação dos cursos do Centro de Línguas, o projeto de instalação da Sala Multimídia na Casa de Cultura Japonesa, a publicação de um livro sobre gramática da língua japonesa e atividades afins, algumas delas concomitantemente e outras em momentos diferentes, devo à compreensão e colaboração deles, em vários momentos deste quadriênio.

Aos professores Toshitada Kitsukawa, Makoto Kuno e Mariko Kuno, e ao Sr. Yoshitake Obata, por me possibilitarem empreender a pesquisa no Japão, abrindo várias portas e me proporcionarem comodidades que somente quem tem coração gentil e generoso pode realizar.

Aos informantes japoneses, que se prontificaram a atender e colaborar com a pesquisa, muitas vezes dentro de uma rotina massacrante que é a vida social japonesa.

Por fim, devo registrar meus agradecimentos à Fundação Japão, pela concessão da bolsa para Pesquisadores sobre o Japão - categoria doutorando, e à Universidade de Kanagawa, que por intermédio das instituições Centro de Pesquisa de Materiais Nãoescritos e Programa de Pesquisa de Materiais Históricos e Étnicos, me concedeu uma bolsa e acolhida no Japão.

Sou grato a todos e, como de praxe, é desnecessário afirmar que a limitação do meu trabalho se deve à incapacidade de não ter conseguido atender às expectativas de acima citados, e ainda de outros que, de forma direta ou indireta, contribuíram para a concretização desta tese. 


\section{ÍNDICE}

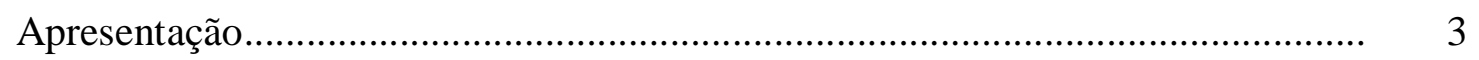

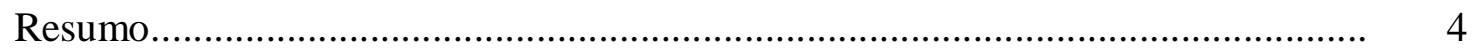

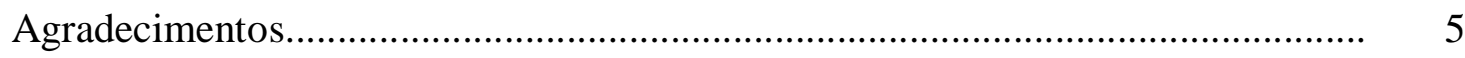

Capítulo1-Introdução e Proposição do Tema.............................................................. 11

1.1- O estudo da hierarquia social da sociedade japonesa e suas justificativas... 11

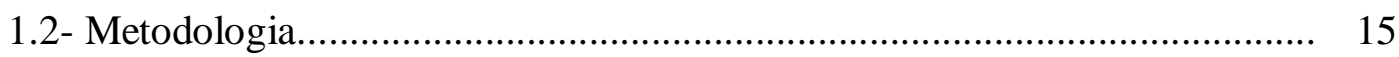

1.2.1- Pesquisa de campo........................................................ 15

1.3- Estruturação do trabalho........................................................................ 16

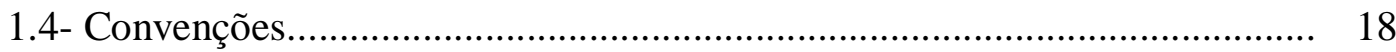

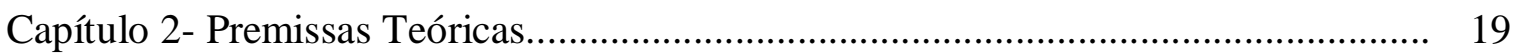

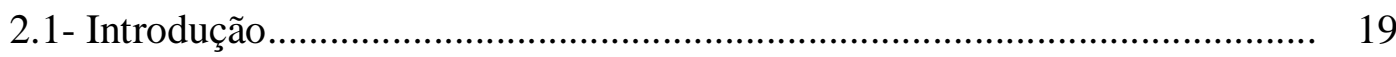

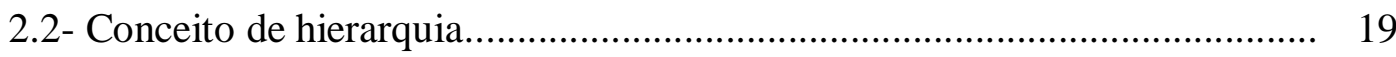

2.3- A hierarquia na sociedade japonesa: debates e teorias............................ 22

2.3.1- Ruth Benedict: "O Crisântemo e a Espada"................................. 22

2.3.2- Nakane Chie: sociedade vertical............................................ 27

2.4- Síntese e conclusão do capítulo......................................................... 35

2.4.1- Legado dos clássicos............................................................ 35

2.4.2- Agência e Estrutura.............................................................. 36

Capítulo 3-Tradição da Hierarquia na Sociedade Japonesa: um breve histórico............ 40

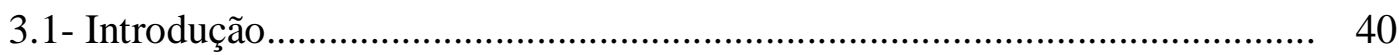

3.2- O surgimento das aldeias e conflitos armados...................................... 44

3.3- Confederação de comunidades: Kuni.................................................. 46

3.4- Estado de Yamato.................................................................................. 49 
3.5- Transmissão do budismo e a Reforma de Taika........................................... 54

3.6- Ritsuryôkokka - Estado legista........................................................... 59

3.7- Regência e tomada do poder pela nobreza................................................. 62

3.8- Ascensão dos guerreiros - bushi .......................................................... 63

3.9- Domínio e estabelecimento da sociedade dos guerreiros.......................... 67

3.10- Daimiôs de guerra e Período Edo (1603 a 1868) ....................................... 71

3.11- Fim da era dos samurais e o advento da modernidade .......................... 76

3.12- Consolidação do Estado moderno e envolvimento nas guerras................ 78

3.13- Considerações finais do capítulo............................................................ 80

Capítulo 4- O Imperador e a Hierarquia Social: de deus mitológico à simbologia.......... 85

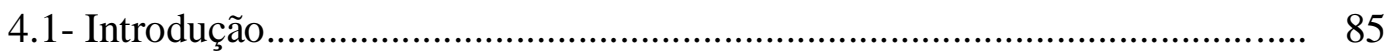

4.2- A origem mítica e a tradição religiosa................................................... 86

4.3- Era Antiga: Estado imperial centralizado............................................ 89

4.4- Período feudal: legitimidade dos governos............................................. 89

4.5- O imperador e a modernização do Japão.................................................... 91

4.6- O caráter simbólico e a polêmica sobre a responsabilidade na guerra......... 92

4.7- O Imperador e a hierarquia: análise do resultado da pesquisa.................. 93

4.8- Considerações finais do capítulo.......................................................... 96

Capítulo 5-Classe Social, Estratificação e Hierarquia................................................... 98

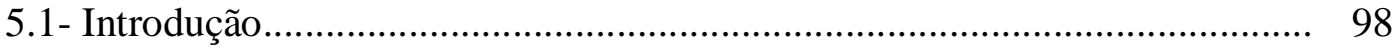

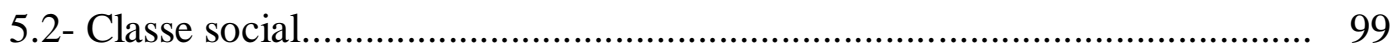

5.2.1- Visão clássica de classe social: tradições marxista e weberiana... 100 
5.2.1.1- Karl Marx e tradição marxista..................................................... 100

5.2.1.2- Max Weber e tradição weberiana.............................................. 103

5.2.2- Visão conciliadora de classe social: alguns destaques................. 104

5.2. 3- Teoria de classe social na Sociologia japonesa....................... 106

5.2.3.1- Histórico............................................................................ 106

5.2.3.2- Shakai kaikŷ̂: um conceito controverso................................ 109

5.3- Estratificação social....................................................................... 112

5.3.1- Estratificação social: conceito ............................................ 110

5.3.2- Shakai kaisô: estratificação e classe social................................ 115

5.4- Tendência ao centro da "identificação da posição social"......................... 116

5.5- Estratificação, classe social e hierarquia.................................................. 119

5.6- Considerações finais do capítulo.......................................................... 122

Capítulo 6-Família, Escola e Empresa................................................................... 126

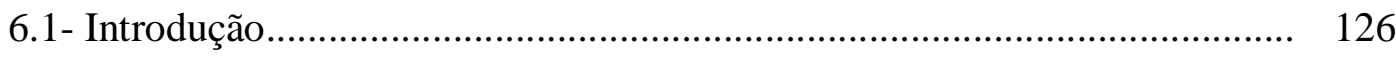

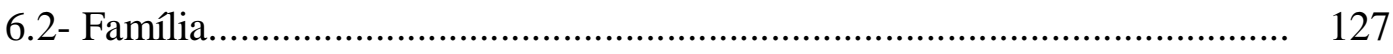

6.2.1- Período até a Segunda Guerra Mundial: predominância de ie, "família tradicional" ............................................................................... 129

6.2.2- Período pós Segunda Guerra Mundial: novo modelo de família..... 134

6.2.3- Análise do resultado da pesquisa de campo................................ 137

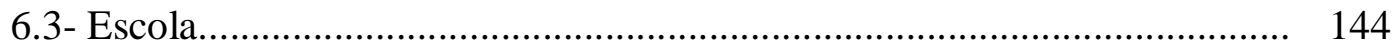

6.3.1- Um breve histórico da escola no Japão........................................... 145

6.3.1.1- Escola do Império Japonês.......................................................... 147

6.3.1.2- Nova educação no pós-guerra................................................. 149 
6.3.2- A escola e a consciência hierárquica............................................... 150

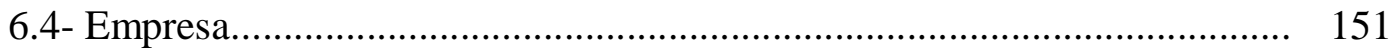

6.4.1- Década de 1960 a 80: expansão econômica e peculiaridades da empresa japonesa........................................................................ 152

6.4.1.1 - "Contratação vitalícia”, idade e tempo de serviço......................... 153

6.4.1.2- A empresa como "família" ......................................................... 154

6.4.2- Alteração na relação de trabalho: década de 1990 a dias atuais...... 155

6.4.3- Empresa e consciência hierárquica................................................. 158

6.4.4- Considerações finais................................................................ 160

Capítulo 7- Dimensão Temporal: idade e ordem de ingresso no meio.......................... 165

7.1- Introdução.................................................................................... 165

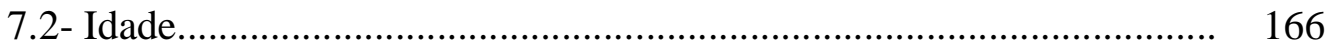

7.3- Ordem de ingresso no meio.............................................................. 168

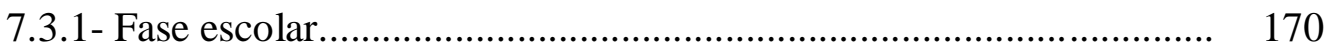

7.3.2- Local de trabalho.................................................................. 173

7.4- Considerações finais do capítulo....................................................... 176

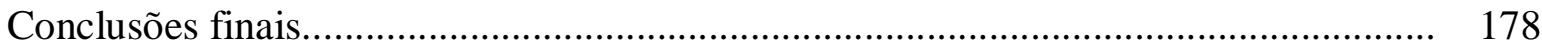

Bibliografia de Referência....................................................................................... 187

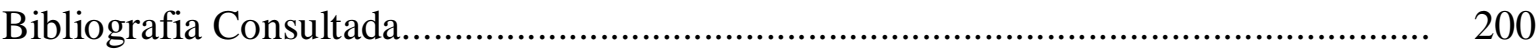

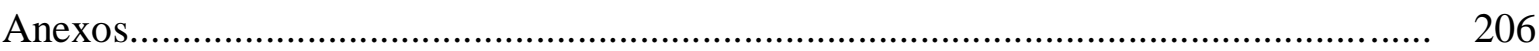

Descrição da pesquisa de campo.......................................................... 207

Perfil dos informantes...................................................................... 208

Respostas do questionário.................................................................. 211

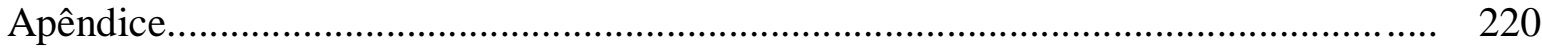

Mapa do Japão............................................................................... 221 


\section{Capítulo 1}

\section{Introdução e proposição do tema}

1.1- O estudo da hierarquia social da sociedade japonesa e suas justificativas

O objetivo do presente trabalho é analisar e procurar compreender a hierarquia social do Japão contemporâneo, com foco na consciência hierárquica do setor médio ${ }^{1}$ da sociedade. Várias razões podem ser elencadas como justificativa para esta empreitada, e duas serão aqui destacadas.

Em primeiro lugar, é possível apontar para uma justificativa histórica e sociocultural, no sentido mais amplo possível do termo. É sabido que o Brasil comporta a maior comunidade de japoneses fora do Japão ${ }^{2}$, que expressa vínculos históricos, políticos, econômicos e culturais entre os dois países, a despeito de estarem situados em pontos opostos mais distantes do planeta. Embora, do ponto de vista econômico, a relação nipo-brasileira tenha demonstrado fases mais exuberantes nas décadas de 60 e 70 do século passado, e essa relação tenha entrado em relativo declínio nas décadas de 80 e 90 com a crise e estagnação econômica desse período ${ }^{3}$, há uma tendência atual de revigoramento dos laços comerciais e econômicos.

Do ponto de vista cultural, a última década teve vários momentos de "onda da cultura japonesa", trazendo à tona diversos aspectos como culinária, esportes, artes

\footnotetext{
${ }^{1} \mathrm{O}$ significado desse termo no presente trabalho será esclarecido nos capítulos 2 e 5.

${ }^{2}$ Cerca de 1,3 milhões, incluindo os nativos que se estabeleceram de forma permanente e descendentes.

${ }^{3}$ A década de 1980 foi, para o Brasil, período de hiperinflação, problema este que começou a ser debelado pelo Plano Real introduzido em 1994. Em contraste ao Brasil, o Japão teve uma década de 1980
} 
marciais, literatura, mangá, animê e cosplay. A comemoração do Centenário da Imigração Japonesa ao Brasil, em 2008, veio coroar esse movimento, despertando mais interesses e potencializando o efeito propagador da cultura japonesa.

Como que naturalmente, todo esse destaque dado a tudo que é nipônico enfocou também o aspecto social, a peculiaridade das relações sociais e as idiossincrasias presentes na interação entre os japoneses.

No caderno especial "100 anos de Imigração Japonesa", o jornal Folha de S. Paulo ressaltou, entre outras características, a observância das regras sociais e o respeito aos idosos como valores herdados pelos nipo-brasileiros, que têm "origem histórica, social e cultural dos imigrantes" 4 .

Em uma das veiculações correntes sobre as curiosidades do país do sol nascente, o programa televisivo Jornal da Globo destacou, na reportagem do correspondente em Tóquio, a hierarquia social, principalmente a observação da relação "veteranos" e "novatos", como característica da sociedade japonesa".

Dessa forma, é possível afirmar que ao destacar a peculiaridade das relações sociais dos nipônicos, os meios de comunicação de massa, pela sua natureza, tendem a mostrá-la como diferente, exótico, isso quando não se quer dizer que são explicitamente indecifráveis, em muitos casos. Há um silêncio ilustrativo sobre o porquê dessas peculiaridades, isto quando não apelam para o clichê "tradição", sem muito esclarecer sobre seu conteúdo.

Por outro lado, não seria exagero afirmar que a referida efervescência da cultura japonesa verificada nos anos recentes parece não ter alterado a visão que perdura no imaginário dos brasileiros no que se refere à sociedade japonesa, principalmente no

gloriosa, até o estouro da bolha imobiliária e financeira em 1991, de cujas consequências não se recuperou completamente. Atualmente, no Japão, fala-se de "duas décadas perdidas".

${ }^{4}$ Edição de 18 de junho de 2008. 
tocante às relações sociais. De fato, isso vem de longa data e pode ser constatado em diversas publicações e divulgações da mídia recentes, como os poucos exemplos seguintes podem demonstrar.

Na publicação Os Japoneses, que faz parte da coleção que tem como objetivo apresentar os principais povos e civilizações do mundo, a sociedade japonesa é caracterizada pelo predomínio da hierarquia, como "resquícios do passado feudal" (Sakurai, 2007: 265).

Mais recentemente, o jornal Folha de S. Paulo classificou o Japão como um dos países do Extremo Oriente, onde "apesar de democracias, são tão rígidos na hierarquia" e "cada indivíduo tem um papel bastante claro a desempenhar com seus superiores ou com subordinados" 6 .

Certamente, as peculiaridades encontradas nas diversas manifestações culturais nipônicas têm como fundamento a sua visão de mundo, o ideal do relacionamento interpessoal, o desejável e o indesejável das diversas interações cotidianas, enfim, a sua idiossincrasia. Se, por um lado, há uma demanda maior pela informação e pelo conhecimento da cultura japonesa no seio da sociedade brasileira, há, por outro, a necessidade crescente de melhor compreender as suas vicissitudes, e de uma compreensão das suas relações interpessoais. Mais ainda, se essa compreensão ocorrer desprovida de mitos e estereótipos, seria, certamente, uma das condições para o seu êxito. Aliás, essa tarefa não tem sido fácil, nem para os próprios japoneses, aparentemente.

Em segundo lugar, há uma justificativa que poderia ser denominada acadêmica ou de ampliação do conhecimento. As pesquisas sobre as relações interpessoais da sociedade japonesa, principalmente no que se refere à hierarquia social, são incipientes,

\footnotetext{
${ }^{5}$ Edição de 17 de novembro de 2010.
} 
restritas a poucos estudos, que serão apresentados no capítulo correspondente. Em outras linhas de análise, nos anos 80 e início dos 90 do século passado, predominaram obras de abordagem economicista, tentando analisar e compreender o êxito econômico japonês ${ }^{7}$. No Brasil, é notória a escassez de trabalhos a respeito da sociedade japonesa, publicados ou não ${ }^{8}$.

Outro aspecto que se refere à ampliação do conhecimento, no ensino do idioma japonês, sendo a língua um dos componentes primordiais da cultura, há fatores socioculturais que estão por trás do seu emprego e que devem ser ensinados para os aprendizes. Esses fatores são de peso relevante na transmissão da língua japonesa, mas de um modo geral, carecem de fundamento teórico, sendo tratados como pressupostos e apenas apresentados descritivamente.

Se observarmos como essa questão é tratada no Brasil, torna-se ainda mais problemática, pois muitas vezes fica dependente da experiência pessoal do professor ou de relatos vagos que são colocados genericamente. Em muitos casos, isso acaba deturpando o conhecimento sobre a sociedade japonesa, pois, se cada professor se vale apenas de suas experiências, que são restritas, múltiplas serão as "imagens" do Japão que são transmitidas aos aprendizes ${ }^{9}$. Uma das possíveis causas que potencializam esse problema está o fato de que há poucos trabalhos, produções e publicações sobre a sociedade japonesa. No Brasil, nem ao menos um livro de história do Japão, com nível desejável de conteúdo, existe. Como consequência, essa situação acarreta uma dificuldade maior para melhor compreensão e divulgação da cultura japonesa.

\footnotetext{
${ }^{6}$ Edição de 08 de maio de 2011, caderno mercado, p. B5.

${ }^{7}$ Nessa linha de análise, destacam-se Vogel (2001) e Johnson (1982).

${ }^{8}$ Destacam-se Uehara (2001) e Hirata (1993).

${ }^{9}$ É possível ainda citar a diferença entre gerações, que possuem visões diferentes do Japão, embora esse aspecto esteja ultimamente mitigado pela transição: os mais antigos transmitiam a imagem do Japão anterior à guerra, uma versão idealizada do Japão perfeito, em grande parte contaminada pela propaganda ideológica da fase militar japonesa.
} 
O presente trabalho não possui nenhuma pretensão de solucionar todos os problemas acima elencados, que são históricos e crônicos, mas pretende oferecer uma pequena contribuição para a compreensão da sociedade japonesa, ao enfocar o fator da hierarquia social, considerado o cerne da interação entre os japoneses, como será discutido no segundo capítulo e estudado ao longo do trabalho.

\section{2- Metodologia}

A metodologia empregada para a consecução do presente trabalho é indutiva, com o procedimento de leitura analítica da bibliografia para o estabelecimento do referencial teórico e como fonte de dados e informações, e uma pesquisa de campo realizada na forma de entrevistas e de aplicação de questionários, como será detalhada a seguir.

\subsection{1- A pesquisa de campo}

Como será explanado no capítulo seguinte, de acordo com o referencial teórico, estabeleceu-se que o objetivo da pesquisa de campo seria verificar a consciência dos japoneses no que se refere à hierarquia social, nos quesitos: família (casal, filhos, irmãos), trabalho (relação com o superior, subordinados, desempenho profissional), renda, escolaridade, status social, gênero, relação "veteranos" e "novatos", idade e hierarquia no imaginário social. Diante do amplo gama de assuntos a tratar, que poderiam, cada um, constituir um tema de pesquisa, decidiu-se por tratar de todos, mesmo correndo o risco de ser superficial em alguns aspectos. Contribuiu também para 
essa decisão a disposição de verificar quais desses quesitos, certamente todos vinculados com a hierarquia social, teriam maior peso na constituição da consciência hierárquica dos nipônicos.

A pesquisa foi realizada em pouco mais de três meses, durante uma permanência de cerca de quatro meses no Japão, de meados de julho a novembro de 2011.

Foi estabelecido como prerrequisito para informantes: homens e mulheres de 20 a $69 \operatorname{anos}^{10}$, residentes na região metropolitana, que tenha ocupação ou alguma experiência profissional.

Com o apoio e a colaboração das prefeituras, da seção internacional do governo das províncias e dos centros comunitários das cidades, foram realizadas entrevistas e aplicação de questionários, desde que os interessados preenchessem o prerrequisito acima. Foram coletados dados de 81 informantes $^{11}$, de todas as regiões do Japão, incluindo a ilha de Okinawa, no sul do arquipélago.

Uma descrição mais detalhada da pesquisa será feita no Anexo do presente trabalho.

1.3- A estruturação do trabalho

Este trabalho foi estruturado em sete capítulos, acompanhados de conclusões finais, bibliografia, anexos e apêndice. Os sete capítulos que constituem o núcleo do trabalho foram elaborados e organizados de uma forma que permita fazer a exposição

\footnotetext{
${ }^{10}$ Padrão adotado na pesquisa SSM (Social Structure and Mobility), que será apresentado com detalhes no capítulo 5.

${ }^{11} \mathrm{O}$ que corresponde a $77,9 \%$ do total de tentativas. Houve 15 questionários inválidos, sendo um incompleto e os demais devolvidos em branco, e 8 não devolvidos, o que corresponde a 14,4\% e 7,7\%, respectivamente.
} 
ordenada da discussão, por si complexa e passível de divagações de diversas naturezas, uma vez que o tema envolve múltiplos aspectos da história da sociedade japonesa.

Em seguida, apresenta-se uma síntese dos capítulos:

Capítulo 2 -Premissas teóricas: neste capítulo será apresentado o referencial teórico do trabalho, ou seja, uma síntese das principais discussões teóricas, a começar pelo conceito de hierarquia social;

Capítulo 3 - A Tradição da Hierarquia na Sociedade Japonesa: um breve histórico: será um capítulo de retrospectiva histórica, em que os principais acontecimentos da história do Japão serão sintetizados, destacando-se aqueles relevantes para o estabelecimento da hierarquia social e a visão dos japoneses sobre o assunto;

Capítulo 4 -O Imperador e a Hierarquia Social: de deus mitológico à simbologia: na extensão do capítulo precedente, será dado um enfoque particular à figura do imperador, analisando sucintamente os aspectos mitológico, religioso e político, e enfocando principalmente a fase do pós-guerra, o processo da transição do líder político ao simbólico, importante para se compreender o entendimento da hierarquia pelos japoneses. Será feita uma análise sobre a relação do imperador e a consciência hierárquica, verificada na pesquisa;

Capítulo 5- Classe social, Estratificação e Hierarquia: discutem-se inicialmente os conceitos de "classe social" e de "estratificação social", tradicionais da Sociologia, para posteriormente verificá-los no contexto da sociedade nipônica, e a validade da análise que os relaciona com a hierarquia social, na sociedade japonesa contemporânea;

Capítulo 6 - Família, escola e empresa: este capítulo será destinado a analisar a produção e reprodução da noção da hierarquia na sociedade japonesa e como isso se apresenta nas principais instituições sociais, dentro de suas peculiaridades; 
Capítulo 7 - Dimensão temporal: idade e ordem de ingresso no meio: este capítulo se destina a estudar o fator da relação "senpai" e "kôhai", ou "veterano" e "novato", posições estas que são estabelecidas ou pela idade ou a partir da ordem de ingresso em determinado ambiente.

\section{4- Convenções}

A transliteração das palavras da língua japonesa ao alfabeto do português seguiu basicamente o sistema Hepburn, comumente adotado, com algumas adaptações destinadas a sanar dificuldades comuns encontrados pelo leitor brasileiro: os sons longos serão sinalizados com o acento circunflexo: assim, por exemplo, será grafado nihon rettô (arquipélago japonês) e não nihon retto. Entretanto, essa regra não será aplicada nos nomes próprios, uma vez que há grafia consolidada sem o emprego do acento.

Os nomes próprios, como o nome dos autores japoneses, será grafado obedecendo a ordem empregada no Japão, ou seja, primeiro o sobrenome, seguido do nome que seria, no Brasil, o prenome ou nome de batismo. Por exemplo, teríamos Nakane Chie que, no Brasil, seria Chie Nakane. 


\section{Capítulo 2}

\section{Premissas teóricas}

\section{1- Introdução}

O objetivo deste capítulo é apresentar de forma sucinta o referencial teórico que norteará o presente estudo.

Para tanto, inicialmente, será feita uma discussão sobre o conceito de hierarquia social e, em seguida, serão apresentados os principais debates e modelos teóricos sobre a hierarquia na sociedade japonesa, por meio da revisão bibliográfica crítica de principais trabalhos sobre o assunto. Por fim, será discutida a relação ação-estrutura, elucidando a diretriz que orientará a análise, por meio da teoria da estruturação.

A contribuição teórica de outros autores para questões pontuais, não menos importante para a análise, será apresentada e discutida em cada capítulo.

\section{2- $\mathrm{O}$ conceito de hierarquia}

A hierarquia é um conceito que está pressuposto, mesmo que muitas vezes não citado nominalmente, nos estudos sobre a estrutura social ${ }^{12}$, mas nem sempre definido claramente. Nas publicações que têm como objetivo apresentar os principais conceitos

\footnotetext{
12 Em um caso raro de menção explícita, Lebaron define a estrutura social como "fenômenos de hierarquização multiforme entre os grupos sociais" (2010: 67).
} 
da Sociologia e áreas afins, este termo quase é ignorado ${ }^{13}$. Um dos poucos a definir a hierarquia no Dicionário de Sociologia: guia prático da linguagem sociológica, Johnson assim define:

“Hierarquia é um sistema social no qual o poder é distribuído entre diferentes camadas, pouca ambiguidade havendo sobre quem tem autoridade sobre quem. Quanto mais hierárquico um sistema, maior o número de camadas e, de modo geral, maior a distância entre o topo e a base.

Hierarquia é um conceito importante porque descreve mudanças históricas profundas no papel do poder na vida social e como ela é organizada. À medida que as sociedades tornam-se mais complexas, por exemplo, e mais focalizadas em controle e dominação como fins em si mesmos, o poder transforma-se cada vez mais na capacidade de controlar eventos, recursos e pessoas, organizando-se em forma hierárquica. Esse fato pode ser identificado em virtualmente todas as áreas da vida social, da política e economia à religião e educação” (1997: 124).

Nessa definição, chama atenção, em primeiro lugar, a compreensão de que a hierarquia é um "sistema social". Como é sabido, um sistema pressupõe uma estruturação de partes interdependentes que, no seu conjunto, formam uma totalidade ${ }^{14}$. Essa totalidade não é mero agrupamento de estruturas que a compõem, é a dinâmica entre elas, em que uma é definida em função de outras partes, que forma o sistema. Para

${ }^{13}$ Cf. Dortier (2010); Lebaron (2010); Edgar \& Sedgwick (2003); Outhwaite \& Bottomore (1996); Bobbio et al. (1992). Nenhuma dessas publicações traz o conceito de hierarquia.

${ }^{14}$ Cf. Johnson, op. cit., 209. Ainda, os sistemas são "complexos de elementos e relações, separados por fronteiras dos seus respectivos meios ambientes, os quais são sempre mais complexos que os próprios sistemas" (HALL, A. D. e FAGEN, R. E. Definition of systems. In: BUCKLEY, W.(org.) Modern System Research for the Behavioral Scientist. Chicago: 1968, apud Outhwaite; Bottomore (1996)). Na perspectiva funcionalista ou estrutural-funcionalista, a teoria dos sistemas remete a autores como Luhmann (2009) e, antes dele, Parsons (1966). 
Outhwaite e Bottomore, os sistemas sociais "podem ser interações, organizações ou sociedades inteiras" e "os sistemas sociais coordenam ações" (1996: 692). Essas várias concepções que sugerem instâncias diferentes de sistemas sociais ficam claras na definição de Giddens, na qual a sociedade é considerada um sistema social e, ao mesmo tempo, constituída por múltiplos sistemas sociais:

“Todas as sociedades são sistemas sociais e, ao mesmo tempo, constituídas pela interseção de múltiplos sistemas sociais. Estes podem ser totalmente "internos" às sociedades ou transpor as linhas divisórias entre o "interior" e o "exterior", formando uma diversidade de possíveis modos de conexão entre totalidades sociais e sistemas intersociais. (...) Em suma, as "sociedades" são, pois, sistemas sociais que "se destacam" em baixo-relevo de um fundo constituído por toda uma série de outras relações sistêmicas, nas quais elas estão inseridas.” (1989: 134-5).

Em segundo lugar, merece destaque que a hierarquia se estabelece entre diferentes "camadas" e, então, há que se observar a estruturação na qual essas camadas são dispostas, ou colocadas de forma escalonada, dentro do referido sistema.

Por fim, a hierarquia está ligada à distribuição de poder, este definido por Weber como "toda probabilidade de impor a própria vontade numa relação social" e que se refere à dominação, "a probabilidade de encontrar obediência a uma ordem de determinado conteúdo, entre determinadas pessoas indicáveis" (2000: 33). É sobejamente conhecido que Weber classificou a dominação em tradicional, carismática e legal (op.cit.: 139 e ss.). 
Antes de prosseguir, convém verificar como a questão da hierarquia é tratada nas obras clássicas e contemporâneas do gênero, nos estudos sobre a sociedade japonesa.

2.3- A hierarquia na sociedade japonesa: debates e teorias

Na bibliografia sobre a sociedade japonesa, a discussão sobre a hierarquia pode ser localizada em autores como Ruth Benedict, também considerada precursora dos Estudos Japoneses do pós-guerra, e Nakane Chie, conhecida pela tese da sociedade vertical japonesa. Os demais autores se apresentaram complementando essas teses ou se posicionando de forma crítica, como será verificado adiante.

\subsection{1- Ruth Benedict: "O Crisântemo e a Espada”}

Um dos clássicos do estudo da sociedade japonesa, "O Crisântemo e a Espada" de Ruth Benedict consistiu, inicialmente, em um trabalho para compreender o Japão, o inimigo que os americanos estavam enfrentando na Segunda Guerra Mundial. Era necessário conhecer a idiossincrasia dos japoneses para melhor combatê-los. A sua tese principal é a de que o principal padrão de cultura ${ }^{15}$ dos japoneses é o temor da vergonha ${ }^{16}$. Entretanto, o que deve ser aqui destacado são as referências sobre a hierarquia como um dos principais princípios de organização da sociedade japonesa.

\footnotetext{
${ }^{15}$ Termo-chave da tese de Benedict, que considera que o comportamento dos indivíduos é moldado segundo padrões culturais da sociedade à qual pertencem (cf. Padrões de Cultura, s.d).

${ }^{16}$ Benedict assim caracteriza a vergonha entre os japoneses: "A vergonha, dizem eles [os japoneses], é a raiz da virtude. Quem é sensível a ela cumprirá todas as regras de boa conduta. "Um homem que conhece a vergonha" é por vezes traduzido por "virtuoso" ou "honrado". A vergonha ocupa o mesmo lugar de
} 
Benedict considera que a ordem e a hierarquia constituem os principais valores que formam a visão do mundo dos japoneses e que regem a sua sociedade, em contraposição aos de liberdade e igualdade, sobre os quais se fundaram a nação americana. No início do capítulo intitulado "Assumindo a posição devida", Benedict assim descreve a importância da hierarquia no seio da sociedade japonesa:

“Qualquer tentativa de entender os japoneses deverá começar com a sua versão do que significa "assumir a posição devida". A sua confiança na ordem e na hierarquia e a nossa fé na liberdade e na igualdade situam-se a pólos de distância, sendo difícil para nós atribuir à hierarquia seu valor devido como mecanismo social. A confiança japonesa na hierarquia é básica, dentro da sua noção global da relação do homem com o seu semelhante, da relação do homem para com o Estado, sendo que somente através da descrição de algumas de suas instituições nacionais como a família, o Estado, vida religiosa e econômica, é que nos será possível entender a sua visão do mundo" (1972:43).

Em seguida, Benedict contrasta o valor da hierarquia dos nipônicos com o da igualdade, principal e fundamental desde que “os Estados Unidos começaram a ser uma nação":

autoridade na ética japonesa que uma "consciência limpa", "estar bem com Deus" e a abstenção de pecado têm na ética ocidental" (1972: 190). Ou ainda, sobre a sua importância no cotidiano, assim afirma: "A primazia da vergonha na vida japonesa significa, como em qualquer tribo ou país onde a vergonha seja profundamente sentida, que cada um aguarda o julgamento de seus atos por parte do público. Será apenas questão de fantasiarem qual vai ser o veredicto, o fato é que se orientam com relação ao mesmo" (ibid.). Não é de se surpreender que "O Crisântemo e a Espada" tenha sido combatido, sobretudo, nesse aspecto. Entre outros, Sakuta (1967) demonstrou a limitação do conceito de vergonha proposto por Benedict; Inoue (1977) propõe uma nova tipologia de vergonha. Sobre outras críticas a Benedict, cf. Kawashima, 1950 e Tsuda, 1988. 
“A igualdade é o maior e mais moral fundamento das esperanças americanas por um mundo melhor. Significa para nós libertação da tirania, da interferência e das imposições indesejáveis. Significa igualdade perante a lei e o direito de melhorar a condição de cada um na vida. É a base dos direitos do homem conforme estão organizados no mundo que conhecemos. Defendemos a virtude da igualdade mesmo quando a desrespeitamos, ao mesmo tempo que combatemos a hierarquia com virtuosa indignação" (op.cit.: 45).

Para Benedict, a noção de hierarquia entre os japoneses é fruto do processo histórico e faz parte da tradição:

“A desigualdade tem sido durante séculos a regra de sua vida organizada, justamente naqueles pontos onde é mais previsível e aceita. Conduta assente com hierarquia é tão natural para eles como respirar. Não se trata, contudo, de um simples autoritarismo ocidental. Tanto os que exercem controle, como os que estão sob o controle dos outros, agem em conformidade com uma tradição diferente da nossa (...)" (op.cit.: 46).

Sendo histórico e tradicional, a concepção de hierarquia está arraigada, segundo Benedict, em todos os aspectos da vida social, seja nos cumprimentos, na linguagem, na mesura, na conduta diária:

“O Japão, com toda a sua recente ocidentalização, é ainda uma sociedade aristocrática. Cada cumprimento, cada contato deve indicar a espécie e grau de 
distância social entre os homens. Cada vez que um homem diz para outro “Coma" ou "Sente-se", usa palavras diferentes, conforme esteja se dirigindo familiarmente a alguém ou falando com um inferior ou superior. Existe um "você" diferente que deve ser usado em cada caso e os verbos têm radicais diferentes. Os japoneses têm, em outras palavras, o que se chama uma "linguagem de respeito", tal qual muitos outros povos do Pacífico, companhada de mesuras e genuflexões apropriadas. Todo esse procedimento é governado por regras e convenções meticulosas; não é apenas necessário saber a quem é feita a mesura, como também a sua freqüência. Uma mesura correta e apropriada para um anfitrião seria considerada como um insulto por outro em relação ligeiramente diversa com o convidado. E as mesuras classificam-se de várias maneiras, desde ajoelhar abaixando a testa até as mãos espalmadas no solo até o mero inclinar da cabeça e dos ombros. É preciso aprender, e bem cedo, como harmonizar a reverência com cada caso particular" (op.cit.: 47).

Sendo a concepção de hierarquia presente no cotidiano, Benedict credita à família o papel de incutir esse valor, como principal instituição de formação de indivíduos observadores da hierarquia. Segundo essa autora, posteriormente, esse valor adquirido na família é estendido e aplicado na sociedade:

"No Japão, é precisamente na família que são aprendidas e meticulosamente observadas as regras de respeito. Enquanto a mãe ainda leva o bebê preso às costas, empurra-lhe a cabeça para baixo com a mão e suas primeiras lições c onsistem na observância de um procedimento respeitoso com relação ao pai ou ao irmão mais velho. A esposa inclina-se diante do marido; a criança, diante do 
pai; os irmãos mais jovens, diante dos mais velhos e a irmã, diante de todos os irmãos, qualquer que seja sua idade. Não se trata de um gesto vazio. Aquele que se inclina reconhece o direito do outro de interferir em assuntos sobre os quais ele próprio preferiria decidir e o que recebe a saudação assume, por seu turno, certas responsabilidades relativas à sua posição. A hierarquia baseada no sexo, geração e primogenitura constitui parte da vida familiar" (op.cit.: 48).

"Todo japonês primeiro adquire o hábito da hierarquia no seio da família e posteriormente os aplica nos campos mais vastos da vida econômica e do governo" (op.cit. :53) .

Benedict afirma que a "posição devida" de cada um é determinada por algumas variáveis e outros fatores como classe, sexo, idade, laços de família e "relações anteriores", sendo que podem ser cumulativos ou excludentes mutuamente:

"Não se trata apenas de diferenças de classe que devem ser reconhecidas constantemente pela conduta apropriada, embora isto também seja importante. Sexo e idade, laços de família e relações anteriores, tudo passa a fazer parte dos cálculos necessários. Em ocasiões diferentes, até mesmo entre duas mesmas pessoas são requeridos graus diferentes de respeito: um civil poderá ser conhecido de um outro e não cumprimentá-lo, porém, estando de uniforme militar, seu amigo em trajes civis há de saudá-lo. A observância da hierarquia é uma arte que requer a ponderação de inumeráveis fatores, alguns dos quais, segundo cada caso particular, poderão ser anulados mutuamente, enquanto outros podem tornar-se até cumulativos" (op.cit. :47). 
Assim, nesse primeiro momento, é necessário destacar o legado da Benedict no que se refere à centralidade da hierarquia como valor e princípio que rege a sociedade japonesa, e sua incidência sobre os diversos componentes da vida social, como classe, sexo, idade, família e "relações anteriores", embora não esteja claro o que este último significa, na sua obra.

2.3.2- Nakane Chie: sociedade vertical

A hierarquia constitui um dos componentes essenciais do modelo de sociedade vertical ou relação vertical da sociedade japonesa desenvolvido por Nakane Chie, em três trabalhos publicados nas décadas de 60 e 70, do século passado $(1967 ; 1972 ; 1978)$.

Nakane postula que há dois tipos de formas de organização das relações sociais de um determinado grupo, ou dois modos pelos quais um indivíduo participa do grupo social.

O primeiro tipo de organização ocorre segundo alguns atributos dos participantes ou pelo contrato estabelecido entre as partes, e pressupõe relações iguais entre si. Nakane representa essa relação usando o diagrama abaixo (1967: 117):

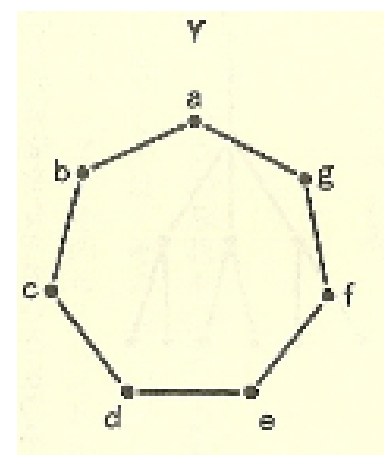


Nesse diagrama, os pontos identificados pelas letras do alfabeto representam os indivíduos que participam do grupo. Nota-se que os indivíduos estão ligados entre si, na relação de igualdade, e a posição é intercambiável, ou seja, a troca entre "a" e "d" ou "b" e "e", por exemplo, não altera a estruturação geral do grupo. Entretanto, a inclusão de um novo indivíduo, suponha-se " $h$ ", afeta todo o grupo. Em alguns grupos, essa inclusão precisa ser aprovada por todos ou pela maioria, mas de um modo geral, há um regulamento (estatuto, leis etc.), que estipula os prerrequisitos e condições dessa participação, e o contrato que rege a observância desse regulamento. Pode haver hierarquias ou diferenças na forma de participação, de direitos e deveres, mas todos são iguais perante o regulamento, no seu cumprimento. Nakane considera que esse tipo de organização é próprio das sociedades ocidentais, notadamente a americana.

Em contraposição a esse tipo de organização, em que predomina a relação horizontal, Nakane afirma que o modelo que melhor explica a organização da sociedade japonesa é o modelo vertical, no qual os indivíduos participam do grupo em relação de desigualdade. Utilizando-se dos mesmos pontos para representar os indivíduos, essa organização vertical é assim representada pelo diagrama (ibid):

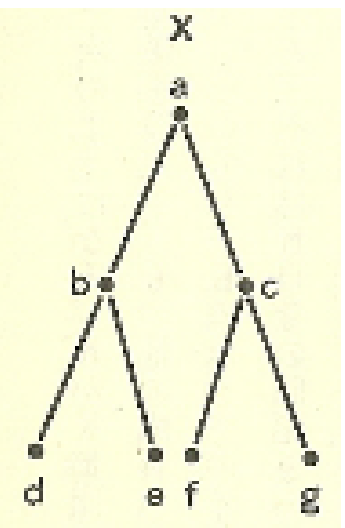

Chama a atenção nesse diagrama, em primeiro lugar, a existência de um indivíduo que ocupa o topo da organização, no caso o "a", no vértice. Toda a 
organização do grupo é centrada nele, de modo que uma eventualidade como a sua morte ou desligamento pode afetar toda a estrutura, podendo a organização esfacelar-se.

Se se analisar a relação do ponto de vista do indivíduo "d", por exemplo, observa-se que:

a) ele não possui acesso direto a "a", a não ser por meio do "b";

b) a relação com "e" inexiste ou, se existir, é tênue; em todo caso, não supera a ligação com "b";

c) muito mais distantes estão os indivíduos "c", "f" e "g".

O que ocorreria, se um indivíduo "h" fosse se incluir nessa relação? Nakane considera que, na organização vertical, os indivíduos ingressam no grupo sob tutela ou na condição de subordinado de algum indivíduo que já ocupa uma posição na relação (1967: 121). Isto não quer dizer que não haja regulamentos ou contratos que possam reger o funcionamento do grupo em que a organização é vertical. Significa que, embora formalmente seus direitos sejam assegurados, o indivíduo que ingressa nesse tipo de organização tem menor margem de autonomia e "liberdade" do que no outro, sendo enquadrado na estrutura de organização já pronta, com seu devido lugar estabelecido. Nas diversas relações que o indivíduo estabelece no grupo, uma prevalece sobre as outras: a ligação com o superior imediato.

Representando essa inclusão no diagrama acima, o "h" ingressaria abaixo de “d”, “e”, “f” ou "g”. Assim, de acordo com a relação que possui com o "tutor" e o tempo de ingresso, o indivíduo " $\mathrm{h}$ " ingressa em posição desigual, hierarquicamente inferior. Dessa forma, um grupo se expande criando ramificações na base, no sentido vertical. Algumas prováveis formas de ampliação do grupo são assim representadas por Nakane (1967: 118): 

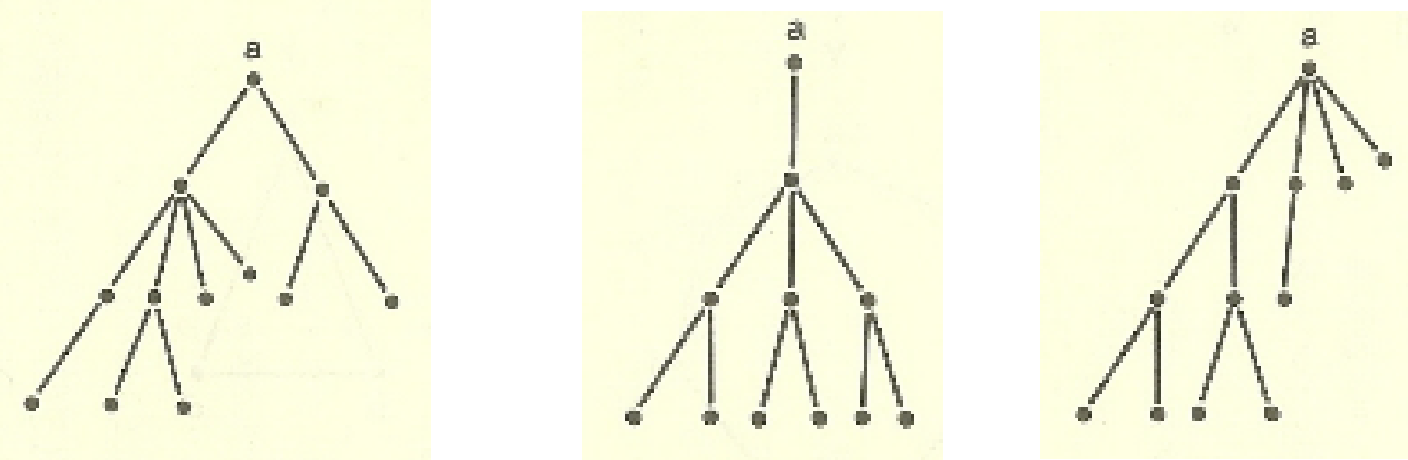

Esse diagrama representa, também, outro postulado de Nakane sobre a participação do indivíduo numa coletividade maior: o indivíduo participa de um grande grupo na condição de membro de um grupo menor $^{17}$ :

“(...) é possível afirmar que, na sociedade japonesa, a participação do indivíduo no grupo sempre se limita ao caso de pequenos grupos, e que somente através deles participa de grandes grupos. Dependendo do grupo, eventualmente, é possível verificar casos em que ocorre a participação direta do indivíduo em um grande grupo, mas de um modo geral, esses grupos são aqueles que não possuem muita importância para sua vida (como um clube de afinidades comuns ou de hobby). Mesmo nesses grandes grupos, há um pequeno grupo no núcleo e os demais são os chamados associados ou participantes gerais, nem todos que formam o grande grupo participam ativamente e tem direito à palavra nas mesmas condições. É possível afirmar que na sociedade japonesa não existem

\footnotetext{
${ }^{17}$ Quando afirma "pequeno grupo", Nakane considera um grupo formado por 5 a 7 pessoas como modelo ideal (1978: 24), embora considere que acima de duas pessoas configure uma unidade analítica (1978: 18). Mills define pequenos grupos como "unidades compostas de duas ou mais pessoas que entram em contato para determinado objetivo, e que consideram significativo o contato", mencionando famílias, comissões de diretores, grupos de construção, grupo de caçadores, comissões de comunidades, grupos de dança cerimonial, clubes de atletismo como exemplos (1970: 12).
} 
grandes grupos com alta funcionalidade em que os indivíduos participam diretamente em igualdade de atributos" ${ }^{18}$ (1978: 35).

Nesse contexto, para Nakane, a hierarquia, como princípio da estruturação da sociedade japonesa ${ }^{19}$, prevalece em todas as relações sociais:

“(...) mesmo entre aqueles que fazem parte do mesmo grupo e que possuem os mesmos atributos, influenciados pela dinâmica "vertical", por algum meio são estabelecidas as “diferenças” e, essas ressaltadas, é definida uma hierarquia que, diga-se, se apresenta surpreendentemente minuciosa" (1967: 72).

É possível afirmar que a análise de Nakane tem como característica a ênfase na localidade, seja a comunidade local, seja a entidade ou corporação onde o indivíduo se emprega, sendo que a menor unidade de análise é o pequeno grupo formado por superior imediato e os colegas, alguns mais "veteranos", outros "iguais" e ainda outros mais "novatos". É esse grupo formado por colegas e superiores do local de trabalho que constitui o prototípico $b a^{20}$, segundo Nakane.

\footnotetext{
${ }^{18}$ Tradução livre nossa, assim como as demais traduções dos trechos do trabalho de Nakane, citados neste capítulo.

${ }^{19}$ Como apontam Sugimoto e Mouer (1982), entre os autores japoneses, Nakane não foi pioneira ao destacar a hierarquia da sociedade japonesa. Embora em nenhum momento Nakane faça menção a respeito, segundo esses autores, ela teria se inspirado no estudo de Aruga (1943), especificamente na descrição da relação denominada "oyabun-kobun" (lit. "status de pai" e "status de filho"), verificada na zona rural japonesa, em que se estabelecia entre os camponeses um simulacro da relação de subordinação e mandonismo verificada nas famílias, na relação entre o pai e os demais familiares, nos moldes da dominação patriarcal (1982: 53). Na década seguinte, o termo "oyabun-kobun" foi empregado para designar a relação hierárquica entre o superior e o subordinado, não somente de dominação, mas também de comprometimento recíproco e envolvimento emocional. Por exemplo, Abegglen o emprega para designar a relação entre os trabalhadores jovens e os velhos, entre o superior e o subordinado, verificada nas empresas japonesas, e o caracteriza como relação informal de caráter paternalista (1984: 90). Atualmente, o termo é empregado para designar principalmente a relação entre o chefe e os membros de quadrilhas, máfia e afins ("cabecilha" e "lacaio").

${ }^{20}$ Para autora, o local de trabalho constitui, assim como as comunidades e entidades de bairro, o que denomina $b a$, literalmente lugar, local, espaço, ambiente. Trata-se de um quadro de referência (frame, cf.
} 
Nakane centraliza sua análise principalmente no local de trabalho, pois considera que, no Japão, as pessoas passam muito tempo nesse local, ou em outras palavras, o trabalho ocupa parcela considerável da vida do indivíduo, quando não exige seu envolvimento total ${ }^{21}$. O mecanismo que atua para que isso ocorra é o de fazer com que o indivíduo se identifique emocionalmente com o trabalho, através da ênfase da coletividade, da união e do espírito de grupo, da valorização do "nós" contra "outros" que não fazem parte do mesmo grupo. Em muitas empresas, esse processo pode ocorrer também por meio de envolvimento dos familiares dos funcionários (participação na festa do ano novo, viagem conjunta dos funcionários com os familiares, confraternização no final do ano, etc.).

Dessa forma, o local de trabalho consiste na principal referência do indivíduo: o indivíduo se autorrefere e classifica os interlocutores (exceto familiares, pessoas íntimas e colegas de trabalho), estabelecendo a si e aos demais certo status, pelo pertencimento a organização (empresas, entidades profissionais), e não pelos atributos ou qualidades pessoais que cada um possui. Assim, ao invés de se apresentarem como "repórter" ou “engenheiro", apresentam-se como "sendo do canal A", "sou da empresa S",22 (1967: $30)$.

Nakane, 1984: 1), que se caracteriza pela condição de pertencimento dos membros, contrapondo-se a atributos (shikaku) natos ou adquiridos, como sexo, idade, origem familiar, escolaridade, profissão, posição social, posses etc. (1967:26). Porém, a validade desse conceito é controversa (Hamaguchi, 2003: 36).

${ }^{21}$ Em 1991, encerrando um estágio e prestes a retornar para o Brasil, fui à empresa onde fazia estágio em 3 de janeiro (no Japão, ainda feriado de Ano Novo) para resolver algumas pendências e, para minha surpresa, lá encontrei a maioria dos funcionários. Diante da minha surpresa, disseram que "se sentia mais à vontade na empresa do que em casa", "os familiares estranhavam a minha presença em casa", "ficava mais à vontade com os colegas" etc. Embora tenham ocorrido mudanças significativas nas duas décadas passadas desde então, o grau de envolvimento e de comprometimento dos japoneses com a empresa onde trabalha é ainda grande. Na visita que fiz ao Japão em setembro de 2010, uma amiga contou que trabalhou em todos os feriados nacionais daquele ano. A questão da dedicação à empresa será retomada no capítulo 6.

22 Seria oportuno acrescentar que, nessas ocasiões, até o nome é irrelevante, demonstrando que a individualidade fica em segundo plano. Isso pode provocar situações cômicas, que a própria Nakane narra: uma pessoa se apresentou para ela sendo da "TV X", e ela pensou que fosse produtor ou operador de câmera, até descobrir posteriormente que se tratava de motorista (1967: 30). 
Segundo Nakane, essa identificação e envolvimento com o grupo, notadamente formado pelos membros do local de trabalho, acarreta também a dependência do indivíduo, no sentido de que dificilmente teria disposição para formar ou fazer parte de outro grupo, com peso igual ou superior. Assim, esse grupo tende a possuir caráter quase que exclusivo na vida social do indivíduo (1967: 65).

Convém esclarecer que Nakane também não descarta a diferenciação por ocupação, status de nascimento ou prestígio social (1967: 72), principais critérios de distinção de classes sociais $^{23}$, mas credita maior importância para a hierarquia estabelecida no interior de pequeno grupo, por razões acima elencadas.

A repercussão da teoria de Nakane foi impactante a ponto de o termo sociedade vertical se tornar recorrente não somente na academia, mas também nas manifestações do público em geral $^{24}$.

Não obstante, surgiram algumas críticas à sua tese. Um dos primeiros a apresentar contrapontos à teoria da sociedade vertical, Yoneyama Toshinao considera que Nakane homogeneíza excessivamente a sociedade japonesa, em dois sentidos. Em primeiro lugar, o padrão de relacionamento dos japoneses não seria tão uniforme quanto sustenta Nakane, pois muitos participam de diversos grupos simultaneamente, sem criar dependência (1976: 65). Em outras palavras, Yoneyama questiona o modelo de Nakane, por dar ênfase excessiva à relação de trabalho, como se a relação social dos japoneses se limitasse a isso. Em segundo lugar, aponta para uma questão de natureza geográfica, Nakane teria desconsiderado a diferença entre o Leste e o Oeste ${ }^{25}$ do Japão. O caráter

\footnotetext{
${ }^{23}$ A rigor, na perspectiva weberiana. As questões sobre a classe social serão discutidas no capítulo 5.

${ }^{24}$ Segundo informação do site de uma livraria, desde 1967, foram vendidos mais de 1,1 milhões de exemplares de As Relações Pessoais na Sociedade Vertical.

${ }^{25}$ Respectivamente, Kantô e Kansai, em japonês. A capital Tóquio faz parte de Kantô, enquanto Osaka pertence a Kansai, por exemplo. A divisão do Japão em Leste e Oeste, ou eventualmente em Norte e Sul, separando-o em duas regiões distintas e com características peculiares, pode ser observada já na Era Paleolítica do arquipélago japonês, expressos na estruturação das aldeias (longitudinais ou circulares), o
} 
vertical da sociedade japonesa se identificaria, segundo Yoneyama, com a região Leste do Japão, apresentando pouca afinidade com a região Oeste, onde reside este autor (op. cit.: 67). Por fim, Yoneyama considera que o modelo de verticalidade de Nakane é restrito, que se aplica às grandes corporações empresariais, órgãos governamentais centrais e instituições universitárias tradicionais, considerados por ele "instituições de elite" (op. cit.: 71), mas não consegue apreender com propriedade outros setores importantes da sociedade japonesa. Sugimoto e Mouer têm opinião semelhante, ou seja, de um modo geral, os estudos sobre a sociedade japonesa têm uma visão elitista (op.cit.: 113) e Nakane não seria diferente: retrata uma realidade restrita de funcionários com perfil de cargo de chefia das grandes empresas (1982: 150) ${ }^{26}$.

Ademais, segundo Nakane, a particularidade do modo japonês de se relacionar com seus pares de trabalho faz com que o convívio seja mais intenso, trazendo como consequência o envolvimento entre eles e também a dependência a esse pequeno grupo. Isso é justificado teoricamente pela distinção entre atributo e quadro de categorização (ba). No entanto, é inegável que o apego a esse postulado acaba promovendo um reducionismo excessivo da sociedade japonesa, de modo que a autora precisa fazer várias ressalvas ao longo do seu trabalho, quando a realidade empírica indica o contrário.

formato dos utensílios de cerâmica encontrados (cilíndricos ou planos), e a disposição e localidade dos túmulos (integrados ou excluídos da aldeia) etc. (Amino, 1997a:4; Okamura, 2002: 62).

${ }^{26}$ Uma discussão mais recente sobre esse tema pode ser encontrado em Takano (2008), que tem como finalidade combater a ideia de que na sociedade japonesa, a tendência é de priorizar o coletivo em detrimento do indivíduo, o chamado coletivismo ou grupismo. Não obstante, no seu trabalho, o tratamento dado à hierarquia é ínfimo, e nas considerações finais do livro, Takano afirma que seu propósito é relativizar o peso dado ao coletivismo nos estudos sobre a sociedade japonesa e que, portanto, sua intenção não seria defender que "não há ação coletiva entre os japoneses", mas que "se procurar, é possível encontrar vários casos de individualismo entre eles" (2008: 305). Para quem tece pesadas críticas ao coletivismo, essa postura surpreende, dá a sensação de que desconstrói sem construir algo em troca. Dessa forma, o autor relativiza e combate a tese da sociedade vertical, mas não oferece modelo alternativo, tampouco contribui para maior esclarecimento sobre a hierarquia. 
É necessário também apontar para a total ausência de referência à figura do imperador na sua análise, como faz Minami, que considera esse fato uma "deficiência irreparável" (1994: 220) ${ }^{27}$. Há que se considerar que o debate sobre o imperador ainda é delicado entre os japoneses (Minami, op.cit., 384), constituindo uma espécie de tabu, mas a sua importância não pode ser negada, principalmente no que se refere à história da hierarquia.

2.4- Síntese e conclusão do capítulo

2.4.1- Legado dos clássicos

Após revisar as principais contribuições das obras clássicas a respeito da hierarquia social na sociedade japonesa, os fatores classe, sexo, idade, laços de família e "relações anteriores", segundo Benedict, e relações no local de trabalho, segundo Nakane, emergiram como componentes importantes de determinação da hierarquia. Então, esses elementos serão estudados nos capítulos seguintes, a questão da classe social no capítulo 5, e a família e local de trabalho, no capítulo 6. Pressupõe-se que o que Benedict quis dizer com "relações anteriores" refere-se à dimensão temporal, que será desenvolvida no capítulo 7, no qual também se inclui o fator idade, e a questão de gênero será tratada ao longo do trabalho.

Esses temas constituem, por outro lado, o componente estrutural da hierarquia social, delimitando suas gradações, e é necessário verificar como isso pode ser integrado com a avaliação que o indivíduo faz da hierarquia de si e dos outros. Essa

\footnotetext{
${ }^{27}$ A rigor, no debate com o etólogo Hidaka Toshitaka, no apêndice de Tateshakai no Rikigaku, Nakane admite que o imperador seja o "número um" se se imaginar uma ordenação de todos os japoneses numa
} 
questão remete à discussão tradicional sobre o indivíduo e a sociedade, níveis micro e macro, atomismo e holismo, agência e estrutura.

\subsection{2- Agência e Estrutura}

Para Giddens, os atores ou agentes humanos são dotados da capacidade de entender o que fazem, enquanto o fazem, e por que o fazem, o que denomina “consciência prática" (1989: XIX), que pode ser definida como "conhecimento das regras e táticas mediante as quais a vida social é constituída e reconstituída através do tempo e do espaço" (1989: 72), e ainda é capaz de informar discursivamente sobre boa parte dessa compreensão, o que significa possuir "consciência discursiva" (op.cit.: 5 e $6)$.

Esse postulado serve para refutar a visão que, muitas vezes, a discussão sobre a hierarquia social do Japão faz transparecer, com a descrição de como ela se impõe ao indivíduo, verificada em várias passagens das obras acima tratadas, e ainda em outros estudos que destacam a prevalência do coletivo sobre o indivíduo. ${ }^{28} \mathrm{O}$ que está no fundo dessa visão é a força coercitiva da sociedade, tal qual afirmou Durkheim, como segue:

“A pressão exercida por um ou vários corpos sobre outros corpos, ou mesmo
sobre vontades, não poderia ser confundida com aquela que exerce a
consciência de um grupo sobre a consciência de seus membros. O que a coerção
social tem de inteiramente especial é que ela se deve, não à rigidez de certos

escala linear (1978: 183), resposta esta que foi provocada pelo debatedor. Disto é possível inferir a posição de Nakane, mas de fato não há menção sobre o imperador na sua teoria.

${ }^{28}$ Ver, por exemplo, Inoue (1977) e Araki (1973). 
arranjos moleculares, mas ao prestígio de que seriam investidas algumas representações. É verdade que os hábitos, individuais ou hereditários, têm, sob certos aspectos, a mesma propriedade. Eles nos dominam, nos impõem crenças ou práticas. Só que nos dominam desde dentro, pois estão inteiros em cada um de nós. Ao contrário, as crenças e as práticas sociais agem sobre nós desde fora; assim, a influência exercida por uns e por outras é, no fundo, muito diferente. (...)

E, no fundo, aí está o que há de mais essencial na noção de coerção social. Pois tudo o que ela implica é que as maneiras coletivas de agir e de pensar têm uma realidade exterior aos indivíduos que, a cada momento do tempo, conformam-se a elas. São coisas que têm sua existência própria. $O$ indivíduo as encontra inteiramente formadas e não pode fazer que elas não existam ou que sejam diferentes do que são; assim, ele é obrigado a levá-las em conta, sendo mais difícil (não dizemos impossível) modificá-las na medida em que elas participam, em graus diversos, da supremacia material e moral que a sociedade exerce sobre seus membros. Certamente o indivíduo desempenha um papel na gênese delas. Mas, para que haja fato social, é preciso que vários indivíduos, pelo menos, tenham juntado sua ação e que essa combinação tenha produzido algo novo. E, como essa síntese ocorre fora de cada um de nós (já que envolve uma pluralidade de consciências), ela necessariamente tem por efeito fixar, instituir fora de nós certas maneiras de agir e certos julgamentos que não dependem de cada vontade particular isoladamente" (1999: XXVIII-XXIV).

Então, no nosso estudo, é necessário ter cautela para que não se retrate o indivíduo como mero receptor e seguidor das exigências resultantes da observação da 
hierarquia. Não se pode conceber uma versão japonesa do "indivíduo dopado" pela estrutura, e há que se reconhecer que nos estudos sobre a sociedade japonesa, alguns sucumbem a essa tentação, isto quando, na ânsia de combater essa linha de análise, não acaba radicalizando para o outro pólo, criando um indivíduo extremamente racional nas suas escolhas ${ }^{29}$

Portanto, para avançar no conhecimento sobre a hierarquia japonesa, uma perspectiva a partir dos agentes não pode ser negligenciada. Como afirma Giddens, os indivíduos estão cientes das condições sociais que os cercam, não se limitam a ser condicionados por elas, mas fazem delas constituintes de suas ações:

"Os cientistas sociais se esquecem de que a maior parte de nossas ações como seres humanos é intencional, e de que estamos cientes das razões que nos levam a praticá-las. Todos os agentes humanos dispõem de bastante conhecimento acerca das condições de sua atividade, e tal conhecimento não está condicionado ao que fazem, mas pode ser entendido como elemento constitutivo dessas ações" (2001: 102).

Assim, o indivíduo é o elo entre a ação e estrutura, entendida como "conjunto de regras e recursos recursivamente organizados" (1989: 20), na medida em que ao mesmo tempo em que é limitado pela estrutura, dela se utiliza para sua ação e a reproduz.

Por conseguinte, o ponto de partida do presente estudo é considerar que a hierarquia social e seus atributos inerentes limitam a ação do indivíduo japonês, mas ao mesmo tempo fornecem as possibilidades para que ele compartilhe da visão de mundo

\footnotetext{
${ }^{29}$ Cf. Takeuchi (1995).
} 
com seus pares e se oriente nesse mundo, dando sentido e direcionamento para sua ação. Essa perspectiva gera a necessidade de conhecer a perspectiva do indivíduo japonês no que se refere à hierarquia, o que denominaremos consciência hierárquica.

Em linhas gerais, é a partir desse referencial teórico que o presente estudo sobre a hierarquia da sociedade japonesa será desenvolvido, sendo que Giddens e outros autores não menos importantes serão oportunamente retomados e suas contribuições destacadas nos respectivos capítulos. 


\section{Capítulo 3}

\section{Tradição da Hierarquia na Sociedade Japonesa: um breve histórico}

\section{1- Introdução}

O presente capítulo tem como finalidade expor de forma sucinta, tanto quanto possível, a história do Japão tendo como enfoque a tradição da hierarquia social. Essa síntese também servirá para subsidiar o restante do trabalho, como referência histórica $^{30}$. Para tanto, alguns episódios serão apresentados e destacados em detrimento de outros, e a exposição, embora siga a ordem cronológica, não seguirá necessariamente a divisão comumente adotada em idade antiga, idade média, etc.

Ainda nesta seção, será resumido o período que antecede o surgimento das aldeias e da hierarquização, como produto da vida coletiva, que interessa ao presente trabalho.

Segundo estudos arqueológicos atuais, é possível identificar os primeiros sinais da presença de ancestrais dos japoneses no arquipélago ${ }^{31}$, datada de 80 mil anos atrás, no Paleolítico Médio (Okamura, 2002: 34) ${ }^{32}$. E é possível constatar que no chamado Paleolítico Superior, período que compreende aproximadamente de 35 mil a 13 mil anos atrás, esses habitantes, que eram nômades, viviam de caça, inclusive possuíam técnicas

\footnotetext{
${ }^{30}$ A exposição será embasada principalmente em Sato et al. (2008) e Amino (1997a, 1997b e 1997c), sendo complementada por outros autores que serão indicados nos trechos correspondentes.

${ }^{31} \mathrm{O}$ arquipélago japonês é formado de 6852 ilhas, sendo quatro as principais, pela ordem de localização, a partir do norte: Hokkaidô, Honshû, Shikoku e Kyûshû.

${ }^{32}$ Estimativas a partir de utensílios de pedra encontrados na escavação de Kanedori, na província de Iwate, em 1985. Os vestígios da Era Paleolítica no Japão foram confirmados pela primeira vez em 1949, em Iwajuku, na província de Gunma (Okamura, 2002: 18).
} 
de armadilhas, empregavam utensílios de pedra no formato de faca e machado (op.cit.:

43) e há cerca de 20 mil anos atrás, haviam se espalhado por quase todas as atuais ilhas do Japão (op.cit.: 60). Pela uniformidade e apuro na técnica de confeccionar utensílios de pedras, feitos em etapas, é possível deduzir que esses ancestrais se comunicavam entre si empregando uma linguagem comum (op.cit.: 62).

Por volta de 15 mil anos atrás, iniciou-se um aquecimento gradual da temperatura do arquipélago e uns 2 mil anos depois, começaram a surgir grandes florestas a partir do sul, constituindo a fauna e a flora que forneceriam o sustento para os ancestrais dos japoneses. A necessidade de cozimento e de armazenamento dos alimentos faz surgir a cerâmica, marcando o advento de uma nova era na história, conhecida como Período Jômon ${ }^{33}$.

A mais significativa transformação do Período Jômon é a fixação da moradia num lugar determinado, com o abandono da vida nômade. A moradia era construída sobre covas [tateanashikijûkyo ${ }^{34}$ ], formando aldeia que, além das moradias, tinha local de descarte de lixo e um cemitério, padrão este que se consolida por volta de 10 mil a 9 mil anos atrás ${ }^{35}$. Em aproximadamente 6,5 mil anos atrás, a residência fixa se consolidou em praticamente todas as regiões do arquipélago. Entretanto, é necessário observar que não havia uniformidade no grau de desenvolvimento do que se

\footnotetext{
${ }^{33}$ Literalmente "figuras de corda", refere-se à técnica de marcar a cerâmica entrelaçando as cordas, empregada na confecção de utensílios feitos de argila. Além da corda, eram empregados conchas, bambus e paus para marcar a superfície do utensílio que apresentava uma grande diversificação não somente nas figuras, mas também no formato e modo de confecção, de acordo com a época e região. (Okamura, 2002: 100).

${ }^{34}$ Essa moradia possuía 3 a $6 \mathrm{~m}$ de largura e $5 \mathrm{~m}$ de comprimento, e era coberta com cascas de árvore, capim e terra. Havia ainda moradias maiores, de formato oval, chegando a 40 metros de comprimento.

${ }^{35}$ Em Uenohara, província de Kagoshima, foram encontrados vestígios de 52 moradias e 16 fornalhas, mostrando a dimensão a que chegavam as aldeias (Okamura, 2002: 127). Da fase posterior, o vestígio mais representativo é de Sannai-Maruyama, em Aomori, datado de cerca de 5, 5 mil anos atrás, que cobre uma área de 35 hectares, e presume-se que havia cerca de 500 habitantes e que tenha durado cerca de 1,5 mil anos. Nessa ruína, já é possível constatar construções com pilares usadas nas festividades [hottatebashiratatemono] e suspensas (takayukashiki) (op. cit.: 138-40).
} 
convencionou denominar cultura ${ }^{36}$ Jômon, havia diferenças regionais no que se referem à moradia, utensílios, adereços, sepultamento dos mortos, etc. Não obstante, dois centros se destacaram como prototípicos desse período, um no extremo norte da ilha de Honshû, atual província de Aomori, e outro na ilha de Kyûshû, na região da atual província de Kumamoto e Miyazaki. É significativo constatar que já havia, nessa época pré-civilização, dois pólos, um na região que atualmente denominamos Japão ocidental e outro no chamado Japão oriental. Posteriormente, é no oeste do arquipélago que vão surgir os primeiros germes da civilização japonesa, enquanto que a porção leste, exceto na região do atual Aomori, ficará quase que inóspita até mais ou menos o século X.

A vida em tribos $^{37}$ gera a necessidade do estabelecimento de uma relação de hierarquia para a própria viabilização do convívio, algo mais do que a figura de um simples líder de caça, que já existia na fase nômade. Com o estabelecimento da residência fixa, surge a figura do líder para organizar, coordenar e orientar as atividades de colheita, armazenamento e distribuição de alimentos. Quanto maior a estrutura da aldeia, maior a necessidade de se planejar, preparar e executar diversos trabalhos de construção das moradias ${ }^{38}$ e outras construções de cunho público, como de festividades e "armazéns", assim como de ruas, cercados e valas (Okamura, 2002: 253-54).

\footnotetext{
${ }^{36} \mathrm{Na}$ Arqueologia japonesa, muitas vezes o termo "cultura" é empregado como sinônimo de período histórico ou estilo representativo do período, para caracterizar utensílios, moradia, túmulos etc. Assim, o conceito de "cultura" não significa apenas o conjunto de feitos e pensamentos do homem que se expressam no seu modo de vida, mas também inclui fatores como tempo e espaço físico.

${ }^{37}$ Ao retratar essa fase histórica do Japão, é comum o emprego da palavra tribo para designar o grupo social formado pelos homens. A tribo é definida como "grupo social que fala uma língua ou dialeto característicos e que possui uma cultura que a separa das outras tribos", não sendo necessariamente organizada politicamente (Hoebel; Frost, 1984).

38 As ruínas escavadas mostram que havia dois padrões de disposição das moradias nessas aldeias, em forma longitudinal e circular, com variações, como o cemitério afastado ou incorporado juntamente com as moradias, etc. De qualquer forma, as construções eram feitas conscientemente de forma planejada, e não aleatoriamente (Okamura, 2002: 251).
} 
Segundo os arqueólogos, não é possível constatar, nas escavações, vestígios de que tenha existido alguma zona cercada que pudesse sugerir algum privilégio $^{39}$, moradias com estruturas especiais, com algum utensílio ou objeto que significasse diferenciação na posse, ou, em outras palavras, riqueza (Noto, 2011: 22). Tampouco há sinais de exploração do trabalho, portanto, não havia algo semelhante a classes.

Embora seja difícil reconstituir toda a estratificação desse período, se é que existia, é possível presumir que havia diferentes status dentro de uma aldeia, principalmente aqueles originados da divisão do trabalho, sexo, idade e nascimento, mas nada que constituísse uma hierarquia rígida (Okamura, 2002.: 255). Se havia alguma hierarquia, seria de natureza religiosa. Há indícios de que a sociedade do Período Jômon era regida pela prática de magia, desejando sucesso no parto, bom crescimento dos filhos, assim como eram realizadas, por uma espécie de sacerdotes e xamãs, festividades e cultos para desejar fertilidades, boa colheita, caça e pesca. Praticavam-se também enterros e cultos aos antepassados e espíritos, de caráter animístico (Okamura, op.cit.: 284).

A cultura Jômon durou cerca de 10 mil anos e o fato histórico que diferencia esse período com o subsequente é a introdução da rizicultura no norte da atual ilha de Kyûshû, da península coreana ${ }^{40}$, que teria ocorrido por volta de 5 séc. a.C. Segundo estudos recentes, o cultivo de arroz se expandiu pelo arquipélago rapidamente, tanto que em um século, atingiu a península de Tsugaru, no extremo norte da lha de Honshû ${ }^{41}$ (Okamura, op.cit.: 338). A pesca, iniciada há cerca de 10 mil anos atrás, e o

\footnotetext{
${ }^{39}$ Não havia privilégio, mas distinção, como se expressa nos túmulos, que apresentam diversificações. Nas escavaç̃̃es de Sannai Maruyama, por exemplo, foram encontrados quatro tipos, sendo que dois foram identificados: um tipo sendo de líder da aldeia e o outro de crianças (Okamura, op.cit.: 256).

${ }^{40}$ Estima-se que o cultivo de arroz teria se iniciado na península coreana por volta de 3 a 4 mil anos antes da introdução ao Japão (Okamura, op.cit.: 355).

${ }^{41}$ Não estão claros os motivos que levaram os homens do Jômon a introduzirem a rizicultura. Okamura sustenta que não foi por falta de alimentos (op.cit.: 341). Outros pesquisadores defendem a tese de que
} 
consequente desenvolvimento de meios de transportes marítimos, como canoa (Amino, 1997a: 10), foram fatores essenciais para a introdução da rizicultura no Japão. Mas a rizicultura não suplantou de imediato a cultura Jômon, coexistindo com esta por vários séculos.

3.2- O surgimento das aldeias e conflitos armados

Provavelmente pela posição geográfica, próxima da península coreana, as transformações que podem ser consideradas características da chamada cultura Yayoi ${ }^{42}$ se iniciaram e se desenvolveram com maior intensidade no norte da atual ilha de Kyûshû, ao sul do arquipélago, desenvolvendo-se em menor grau também na atual região de $\mathrm{Kinki}^{43}$.

Além da prática de rizicultura, é possível destacar como características do Período Yayoi o emprego de utensílios de bronze e de ferro; maior divisão do trabalho, devido à diversificação das tarefas decorrentes do cultivo do arroz e canalização para sua irrigação, e do surgimento de artesãos capazes de manipular os metais cujas técnicas também foram transmitidas do continente.

ocorreu uma corrente de imigração em escala familiar, que trouxe a prática da rizicultura, influenciando os residentes locais (Terasawa, 2000: 47).

${ }^{42}$ Quando se diz cultura Yayoi, refere-se à cultura baseada na rizicultura, que se expande para o sul da mesma ilha e para o leste, atingindo a ilha de Honshû. No entanto, Hokkaidô esteve fora dessa área de influência, assim como há divergência quanto à região nordeste de Honshû (Tôhoku), se esta chegou a se caracterizar como sendo da cultura Yayoi (Terasawa, 2000: 17). Portanto, a descrição do período Yayoi se concentra, basicamente, no oeste do Japão. 
Registra-se também nesse período o início de conflitos armados ${ }^{44}$ entre as tribos, tendo como foco disputas de terras, águas e alimentos. A frequência dos conflitos teria aumentado a partir do século III, no norte de Kyûshû, expandindo-se ao sul nos séculos seguintes.

Esses conflitos fizeram emergir a figura de chefes locais, da necessidade tanto da mobilização dos aldeãos quanto da organização das estratégias com fins de êxito nas batalhas. A vitória nas batalhas significava o aumento do poder dos chefes, uma vez que aumentava o número daqueles que lhes rendiam obediência, já que a prática da época era anexar as aldeias conquistadas, sendo seus membros incorporados como escravos ou em posição subalterna, com a obrigação de pagamento em forma de produtos e prestação de serviços ${ }^{45}$. Surge, assim, a hierarquia baseada na organização de aldeias para fins de batalha e origina-se a estratificação social pela anexação das aldeias vencidas em condições desiguais.

Dessa forma, os historiadores creditam aos conflitos armados o fator primordial para a instauração da autoridade e do poder dos chefes aldeãos, assim como para o surgimento da estratificação social no Período Yayoi.

Outro fato importante a destacar nessa fase é a consolidação da aldeia como unidade de organização social, sobretudo no Oeste do Japão. Diferentemente das aldeias típicas do Período Jômon, as aldeias da cultura Yayoi eram circundadas por fossos que

\footnotetext{
${ }^{43}$ Região atualmente formada por Osaka, Quioto e outras províncias adjacentes: Nara, Mie, Shiga, Hyôgo e Wakayama.

${ }^{44}$ Introduzidas da península coreana, as técnicas de polimento de pedras contribuíram para o aperfeiçoamento dos utensílios tornando-os mais afiados. Essas melhorias contribuíram para converter até então armas de caça em armas de guerra. As espadas e os piques (lanças antigas) de bronze, também transmitidos da península coreana, serviram para incrementar os armamentos, ao lado do arco e da flecha. ${ }^{45} \mathrm{O}$ primeiro caso, incorporação como escravos, era comum na região norte da atual ilha de Kyûshû, enquanto o segundo, prestação de serviços, era comum na atual Nara, ou seja, região de Kinki (Terasawa, 2000: 143).
} 
as separavam do mundo exterior ${ }^{46}$, com o objetivo de defender-se dos ataques de animais e invasores. Posteriormente, com o avanço da hierarquização na aldeia, os fossos passaram a ser duplos, ou seja, o fosso interior cercava a área central, onde residiam o chefe e a família dominante, e os demais habitantes moravam na área entre este fosso e o fosso exterior ${ }^{47}$. Dessa forma, o espaço físico passou a ser um fator que expressa a hierarquia existente na aldeia (Takesue; Morioka; Shitara, 2011: 72).

Para Terasawa, já por volta de dois séculos a. C., as aldeias formavam pequenas comunidades que compartilhavam a mesma fonte de água, e essas pequenas comunidades podiam ser agrupadas em grandes comunidades, de acordo com a posição no leito do rio $^{48}$ (2000: 142). Algumas grandes comunidades formariam, posteriormente, a confederação de comunidades, ou kuni.

\section{3- Confederação de comunidades: Kuni}

As informações sobre o Japão desse período histórico podem ser em parte conhecidas através dos registros das dinastias que governavam a China. À época, o Japão era denominado Wa, e o primeiro registro a seu respeito data de século I, encontrado no Livro de $\mathrm{Han}^{49}$, onde consta que Wa era composto por cerca de cem

\footnotetext{
${ }^{46}$ As chamadas kangôshûraku, "aldeia cercada de fosso". Por exemplo, nas escavações da província de Fukuoka, foi encontrado um fosso de formato oval com diâmetro de 110 por $81 \mathrm{~m}$, largura de $4 \mathrm{~m}$ e $2 \mathrm{~m}$ de profundidade, cercado por outro fosso maior com diâmetro de 370 por 170m (Terasawa, 2000: 56). Nas planícies, esses fossos eram abastecidos com água, possuindo outras funções complementares como de escoadouro de água nas enchentes e esgoto.

${ }^{47}$ Para Terasawa, essa disposição originou a concepção de interioridade e exterioridade dos japoneses, ainda presente na atualidade, que classifica as pessoas em "os de dentro" e "os de fora", servindo de critério para tratamento diferenciado, inclusive no emprego da linguagem adequada na interação (2000: 58).

${ }^{48}$ Por exemplo, a atual bacia de Nara era constituída por 23 pequenas comunidades, agrupadas em 9 grandes comunidades (Terasawa, ibid.).

${ }^{49}$ Em japonês, Kanjo (leitura japonesa de "Livro de Han" em chinês), organizado por Ban Gu (32-92) na dinastia Han Oriental (ou Posterior), que durou de 25 a 220 d.C.
} 
comunidades denominadas kuni. No Livro de Sui ${ }^{50}$, também consta que Wa era formado por unidades menores denominadas kuni, assim como há menção de "trinta kuni" no Livro do Han Oriental ${ }^{51}$.

Partindo dessas informações, Terasawa propõe que as grandes comunidades, formadas pelo agrupamento das pequenas, sejam denominadas kuni, e que a confederação de kuni seja chamada $K u n i^{52}$. O Kuni, por sua vez, formarim a confederação de Kuni, liga das confederações de grandes comunidades (2000: 143).

Trata-se de uma tentativa, por parte de Terasawa, de diferenciar por níveis de organização as comunidades registradas pela mesma palavra - "kuni" - nas escrituras chinesas. Organizando os tipos de comunidade com a proposta de denominação dos respectivos chefes, segundo Terasawa, temos o quadro seguinte:

\begin{tabular}{|c|c|}
\hline tipo de comunidade & chefe \\
\hline liga das confederações de grandes comunidades & "supremo soberano" - kimi no naka \\
no kimi \\
ou
\end{tabular}

Terasawa aponta, ainda, que nas pequenas comunidades havia uma estratificação por status de família, pela ordem decrescente: família dominante, cujo líder também era

\footnotetext{
${ }^{50}$ Em japonês, Zuisho (concluído em 656), registra os acontecimentos da dinastia Sui (581-618).

${ }^{51}$ Em japonês, Go Kanjo (leitura japonesa de "Livro do Han Oriental" em chinês), organizado por volta do século V.

${ }^{52}$ No japonês, a distinção de kuni, aqui grafado em minúscula, e Kuni, em maiúscula, ocorre no uso de fonograma para o primeiro e de ideograma para o segundo.
} 
o chefe da aldeia (osa); famílias comuns, lideradas pelos chefes de família (kachô); famílias dominadas; por fim, os escravos (seikô) (ibid.).

As principais confederações de grandes comunidades (Kuni) que se destacaram foram Itokoku e Nakoku ${ }^{53}$ que teriam se formado aproximadamente um século a.C., na região norte de Kyûshû. Os vestígios encontrados nos túmulos, como espadas, espelhos, ornamentos de bronze, bolinhas de vidro etc., comprovam a influência da dinastia Han chinesa e que seus mandatários possuíam o status de "soberano" (Terasawa, op.cit.: 157-59). Entre os dois, Itokoku foi o que mais se desenvolveu e dominou as demais confederações, chegando ao auge no início do século II. Uma rebelião que desafiou o seu domínio, na segunda metade do mesmo século, inicia uma fase conturbada, mas Itokoku sobreviveu até o século III, perdendo gradativamente a sua importância para o estado de Yamato.

No Romance dos Três Reinos, do Livro de Wei, no subcapítulo sobre os wajin ${ }^{54}$, "homens de Wa", consta que ocorreu uma grande conturbação e guerras entre reinos do Wa no final do século II, até que a soberana do reino de Yamatai ${ }^{55}$, Himiko, conseguisse pacificar a contenda e formasse uma confederação de trinta Kuni. Himiko teria sido um xamã que, com o poder da magia, teria conseguido unificar os reinos.

O Livro de Wei ainda faz uma descrição detalhada do reino de Yamatai, onde, segundo consta, havia duas categorias de homens, taijin e geko. Estes, ao encontrar um

\footnotetext{
${ }^{53}$ Localizavam-se, respectivamente, na planície de Itoshima e planície de Fukuoka, ambas na atual província de Fukuoka. Em Go Kanjo (leitura japonesa de "Livro do Han Oriental" em chinês), organizado por volta do século V, consta que emissários de Nakoku foram à capital Luoyang, em 57, e receberam do imperador Guangwu (5 a.C.-57) a comenda (esse ato simbolizava o reconhecimento da condição de súdito da dinastia); na segunda citação, registra que, em 107, o soberano de Wa enviou para o imperador Andi (106-125) 160 escravos como oferenda (Sato et al., 2008: 26). Há controvérsias quanto a este soberano de Wa, se seria do Nakoku ou Itokoku, ou da confederação dos dois (Terasawa, op. cit.: 221).

${ }^{54} \mathrm{O}$ romance retrata o Período de Três Reinos (220-265), em que o poder central foi divido em três reinos, Wei, Wu e Shu, e foi escrito por Chen Shou (233-297), na segunda metade do século III. Esse subcapitulo sobre wajin é conhecido como "Registro sobre os homens de Wa do Registro de Wei", Gishiwajinden, em japonês, embora seja uma parte do capítulo que trata dos "povos bárbaros do Leste" (Sato, op. cit.: 28).
} 
taijin nas trilhas, entravam no mato para dar passagem, e para conversar, agachavam-se ou se ajoelhavam no chão, apoiando nas duas mãos. Os homens praticavam a poligamia, pagavam tributos e trocavam os bens excedentes em feiras. Havia poucos crimes, e os infratores podiam tanto perder a esposa e filhos quanto ter os familiares executados, de acordo com a gravidade do ato cometido (Sato et al., 2008: 28).

Ainda há controvérsias quanto à localização do reino de Yamatai, se teria sido no norte de Kyûshû ou na região de Kinki ${ }^{56}$. Atualmente, a maioria dos pesquisadores tende a apoiar a segunda hipótese. Isso não é desvinculado do fato de o primeiro estado, na acepção atual do termo, ter surgido nessa região, como será verificado em seguida.

\section{4- Estado de Yamato}

Em meados do século III, já havia na região Kinki várias comunidades organizadas estabelecendo entre si relações de trocas, de caráter material ou de favores. A consolidação do poderio dos chefes dessa região faz emergir, em meados do século IV, uma liga de confederações de grandes comunidades, tendo como sede Yamato, que passou a dominar toda a região oeste do arquipélago.

Além da dominação das principais confederações, o governo de Yamato conseguiu também o reconhecimento por parte do Paekche ${ }^{57}$, simbolizado por envio de

\footnotetext{
55 Segundo Furuta (2011), esse reino teria existido na atual província de Fukuoka, na região norte da ilha de Kyûshû.

${ }^{56} \mathrm{Na}$ realidade, a discussão se estende por dois séculos. Arai Hakuseki (1657-1725), entre outros, historiador e pesquisador do confucionismo, do período Edo (1603-1868), teria sido precursor da corrente que defende a localização do reino de Yamatai em Yamato (Nara), e Motoori Norinaga (1730-1801), médico e estudioso do vernáculo, do mesmo período, teria sido o primeiro a defender a tese da localização em Kyûshû.

${ }^{57}$ Um dos Três Reinos da Coreia, ao lado de Goguryeo e Silla, que ocupou a região sudoeste da península coreana, e durou de 346 a 660.
} 
uma espada ${ }^{58}$ para o soberano de Wa, em 369. Esse intercâmbio com Paekche, além de promover uma intensa transmissão de conhecimentos e de técnicas do continente, faz com que o Wa se envolvesse na instabilidade da península coreana. O estabelecimento da aliança militar com Paekche faz com que o Wa enviasse tropas para a península coreana para travar combates com Goguryeo e Silla, a partir de 391.

Destaca-se ainda a relação próxima com Kinkan ${ }^{59}$, uma das comunidades de Kara, situado no sul da península coreana. Além de servir de porto de entrada à península coreana, foi de lá que vieram maioria dos imigrantes que trouxeram os cavalos com instrumentos para montaria, assim como o forno e a técnica de confeccionar a cerâmica denominada $\mathrm{Sueki}^{60}$, utensílios agrícolas como enxadas e ceifadeiras, e as técnicas para a construção de diques e canais de irrigação, essenciais para o salto qualitativo da agricultura no arquipélago, na primeira metade do século V.

Em 421, Wa enviou emissários para a dinastia Song ${ }^{61}$ (420-479), restabelecendo a relação com o continente após mais de um século e meio. Nessa fase, ainda são enviadas nove missões à China, sendo a última em 478, ficando a relação, a partir deste ano, interrompida, até 600 .

Impulsionado pelos novos conhecimentos introduzidos via península coreana, o sistema político-militar- administrativo que se instaurou na região de Kinki recebeu a

\footnotetext{
${ }^{58}$ Denominado shichishitô, "espada de sete gumes", atualmente, encontra-se no acervo do santuário de Isonokami, em Nara.

${ }^{59}$ Também denominado Mimana pelos japoneses, até recentemente, era considerado protetorado de Wa. Baseado em Nihonshoki, história do Japão compilada no século VIII, essa tese é rejeitada atualmente pelos pesquisadores (Kumagai, 2001: 23).

${ }^{60}$ Até então, os utensílios como vasos e tigelas eram confeccionados ao ar livre, o que possibilitava esquentar no máximo a $900^{\circ} \mathrm{C}$. Com essa técnica, que queima a cerâmica no forno, foi possível aumentar a temperatura para $1200^{\circ} \mathrm{C}$, aumentando a sua qualidade e a durabilidade.

${ }^{61}$ Dinastia do sul da China, no período das Seis Dinastias, que durou de 420 a 479. É também denominado dinastia Liu-Song, para diferenciar da dinastia Song, que reunificou a China em 960. A adoção da dinastia Song segue a padronização japonesa, que não adota Liu-Song.
} 
denominação de reino de Yamato ou governo de Yamato $^{62}$ pelos historiadores. Suas principais características podem ser assim resumidas:

a) a presença de um soberano que se autointitula "grande soberano", que governa tendo como fonte de legitimidade seu poderio militar e uma rede de acordos firmados com vários chefes de comunidades que lhe renderam fidelidade ${ }^{63}$. Na primeira metade do século VI, essa relação caracterizada como "dominação e subordinação branda" (Amino, 1997a: 63) consolida-se, com o chamado shisei seido ("sistema de clãs e títulos",64). Nesse sistema, os clãs recebiam diversos títulos do "grande soberano", que eram classificados em dois tipos: uji para os principais clãs que habitavam a região central de Yamato, destacando-se os Soga, Mononobe e Ôtomo ${ }^{65}$, e que estavam incorporados na estrutura do poder do "grande soberano", assessorando-o nas questões políticas, militares, religioso-festivas e técnico-produtivas (Kumagai, 2001: 184); kabane indicava a posição política do clã no estado de Yamato, e era empregado após a denominação do uji ${ }^{66}$, indicando a gradação: omi, muraji, kimi, miyatsuko, atai, obito, fuhito (ibid.).

b) a criação de um aparato de Estado, ainda que incipiente, para gerir a administração governamental e garantir o domínio sobre as regiões. Principalmente após a rebelião de um clã regional no início do século VI, o governo de Yamato tomou diversas medidas visando a organizar e intensificar o domínio sobre as diversas regiões. Uma das medidas foi criar o posto de representante oficial, denominado

\footnotetext{
${ }^{62}$ Tradução de Yamato-ôken e Yamato-seiken, respectivamente. Até a década de 80, era usual Yamatochôtei, "corte de Yamato", mas esse termo foi abandonado aos poucos pelos pesquisadores que o consideraram não compatível com a realidade social da época, sendo raramente empregado, atualmente.

${ }^{63}$ As comunidades assim subordinadas denominavam-se tomo.

${ }^{64}$ Tradução de Suzuki, 2003.
} 
kuninomiyatsuko, que era, normalmente, o chefe do clã local nomeado para tal cargo e que arrecadava impostos em forma de produtos, arregimentava os trabalhadores para obras públicas $^{67}$ e soldados, em nome do governo central. Dessa forma, o kuninomiyatsuko exercia o poder executivo local, assim como de comando militar, incluindo ainda o poder judiciário e da autoridade religiosa (Kumagai, 2001: 174). O kuninomiyatsuko enviava membros do seu clã para prestar serviços na corte, o chamado tomo, sendo os principais cargos toneri (guarda-costa e ajudante de ordens), yugei (soldado) e kashiwade (cozinheiro). Esses ficavam subordinados ao tomonomiyatsuko, chefe dos tomo.

O governo de Yamato também instalou sedes administrativas locais denominadas miyake. Este era um posto avançado de caráter político-militar instalado dentro do território dos administradores locais [kuninomiyatsuko], e comandado por um oficial enviado ou nomeado pelo governo de Yamato. Este oficial tinha a função de intermediar a relação entre o governo central e o administrador local, transmitindo as ordens e verificando seu cumprimento. Além do mais, essas sedes administrativas locais [miyake] constituíam uma base de produção, pois possuía celeiros de arroz e tinha sob seu domínio determinadas áreas agrícolas. Havia, ainda, outros miyake com finalidades próprias, destinados à produção de sal, à extração de minerais e à pesca, por exemplo.

Ao longo do século VI, ainda são estabelecidos os agrupamentos de pessoas detentoras de conhecimentos e técnicas próprias [be ou benotami], como tecelão, ferreiro, artesão, criador de cavalos, etc., subordinado ao grande soberano, sua consorte e princesas, para quem prestava seus serviços. Ao mesmo tempo, esses grupos

\footnotetext{
${ }^{65}$ Sobre a história da origem desses clãs, cf. Yasumoto, 2005: 207 a 234.

${ }^{66}$ Por exemplo, Sogaomi, sendo Soga o nome do clã (uji) e omi seu título hierárquico (kabane).

${ }^{67}$ Para construção de estradas e pontes, bem como de tumbas, como será analisado adiante.
} 
profissionais estavam vinculados a principais clãs na condição de subordinados técnicos $\left[k a k i^{68}\right]$, dos quais recebia o nome, como em Ôtomobe, Sogabe etc.

Uma das expressões emblemáticas dos detentores de poder desse período é a construção de suntuosas tumbas ${ }^{69}$, que renderam a denominação desse período histórico. A partir da segunda metade do século IV, tais tumbas começaram a ser construídas no sul da ilha de Kyûshû e também no nordeste de Honshû, na atual região de Fukushima e Miyagi, demonstrando assim a ampliação da influência dos chefes de Kinki e a consequente inclusão tardia dessas regiões à cultura que poderíamos denominar de "tumbas antigas".

O século $\mathrm{V}$ pode ser considerado como o auge da construção de grandes tumbas. A tumba Daisen, construída na atual Osaka, mede cerca de 480m de comprimento e $33 \mathrm{~m}$ de altura, é cercada duplamente por fossas de água. Estima-se que 2 milhões de homens foram empregados para sua construção, o que demonstra o poder do mandatário - "grande soberano"- da época.

O declínio da construção de grandes tumbas na segunda metade do século VI e o seu completo desaparecimento no século VII, seguido do aparecimento de tumbas circulares $^{70}$ construídas de forma agrupada, ${ }^{71}$ expressa a transformação da sociedade: esses túmulos coletivos $^{72}$ foram construídos pelos camponeses que se tornaram independentes do domínio dos chefes locais. Para esse enfraquecimento dos chefes locais contribuiu decisivamente a ampliação do domínio central, por meio do sistema de

\footnotetext{
${ }^{68}$ Etimologicamente, kaki possui a mesma origem de kakine, "cercado", significando, nesse contexto, a delimitação de pertencimento desses grupos aos clãs.

${ }^{69}$ A chamada zenpôkôenfun, "tumba retangular na parte dianteira e circular na traseira", era revestida de pedras, as menores têm comprimento de 40 a 50m, e a maior 200m (Amino, 1997a: 52). A parte traseira, circular, constitui o sarcófago onde o chefe morto era colocado em esquifes de madeira comprido, feitos de troncos de árvores escavados, juntamente com seus pertences como espada e espelho. O costume de colocar pertences do morto já era praticado no período Yayoi.

${ }^{70}$ Enfun, em japonês.

${ }^{71}$ Dependendo do caso, chegavam a centenas, construídas numa área determinada.

${ }^{72}$ Em japonês, gunshûfun.
} 
administradores locais [kuninomiyatsuko] e subordinados técnicos [bemin], conforme relatado anteriormente (Kumagai, 2001: 191).

\section{5- Transmissão do budismo e a Reforma de Taika}

No século VI, conforme visto anteriormente, o poder estava concentrado nos clãs, que dominavam a máquina administrativa do governo de Yamato.

Nesse contexto, o maior acontecimento histórico que vai modificar profundamente a sociedade de Yamato é a transmissão do budismo, via península coreana, em meados do século $\mathrm{VI}^{73}$. De imediato, alguns clãs se converteram ao budismo; outros o viam com desconfiança, e alguns até o consideravam uma ameaça. A verdade é que já por volta de 569, essa divergência em torno da religião forasteira tornou-se uma questão política de gravidade. Na realidade, a contenda era, no fundo, uma disputa de poder travestida de conflito religioso; o budismo, vindo do continente, ao mesmo tempo em que era uma novidade, trazia consigo conhecimentos avançados, relacionados com as técnicas de construção de grandes templos e estátuas budistas.

A disputa entre o clã Soga, favorável ao budismo, e o clã Mononobe, desfavorável a essa religião forasteira, chega ao ápice em 587, após a morte do imperador Yômei ${ }^{74}$, quando desemboca em conflito armado. Vencendo o clã Soga, favorável ao budismo, Nara passa por grandes transformações, como a construção do

\footnotetext{
${ }^{73}$ Sobre o ano em que ocorreu a transmissão do budismo, há duas teses, a de 538 e a de 552 . De qualquer forma, é certo que o rei Song-Myong, do reino de Paekche, localizado ao sul da península coreana, enviou estatuetas e sutras budistas ao soberano de Yamato.

${ }^{74} \mathrm{O}$ imperador Yômei (? - 587) foi o primeiro imperador a se converter oficialmente para o budismo. Sua permanência no trono foi curta, de apenas dois anos.
} 
templo Asuka ${ }^{75}$, o primeiro templo budista a ser erguido no Japão, iniciado em 588 e concluído em 596.

No início do século VII, o governo de Yamato adota uma série de medidas para modernizar e fortalecer o aparelho do Estado. Em 603, foi estabelecida a "ordenação de 12 posições hierárquicas ${ }^{76,}$, que determinava a hierarquia dos burocratas que prestavam serviço na corte. As 12 posições eram designadas de acordo com seis termos do confucionismo $^{77}$, acrescidos de palavras "grande" e "pequeno" 78 para cada um, e essas posições eram representadas pela "coroa", uma espécie de quepe sem pala, de cores roxo, azul, vermelho, amarelo, branco e preto, com duas tonalidades cada uma, que os burocratas eram obrigados a usar nas cerimônias e eventos oficiais. Oficialmente, esse sistema visava a promover os burocratas qualificados independentemente de sua origem, incrementando assim, os recursos humanos do governo, mas os principais clãs e membros da família de "grande soberano" ficaram isentos da obrigação e, portanto, acima da ordenação, mantendo seus privilégios (Kumagai, 2001: 233).

Em 604, entrou em vigor o "Código de 17 Artigos"79, que se trata mais de um código moral e religioso do que de uma lei, como pode ser percebido na síntese seguinte:

\footnotetext{
${ }^{75}$ Também denominado templo Hôkô.

${ }^{76}$ Em japonês, Kan'i jûnikai, "ordenação em 12 níveis de coroa", teria sido inspirado em sistemas similares de Goguryeo e Paekche.

${ }^{77}$ Em japonês, Jukyô, o confucionismo é considerado uma espécie de "religião de estado" (Confúcio, 2005: XV), pelo fato de que os imperadores chineses estabeleceram e promoveram o culto de Confúcio (551-479 a. C.). São destacados, sobretudo, os valores morais que devem ser respeitados no trato da coisa pública, daí o fato de ele ser considerado uma doutrina administrativa dos letrados, burocratas do estado (Weber, 1982: 291). Kaji ressalta o aspecto religioso do confucionismo que se caracteriza pela visão própria da morte e pelo culto aos antepassados, afirmando que, de um modo geral, o aspecto moral é demasiadamente enfatizado em detrimento do aspecto religioso (1990: 32 e ss.).

${ }^{78}$ Eram os termos toku (virtude), jin (benevolência), rei (cortesia)çgh0oh, shin (credibilidade), gi (justiça) e $c h i$ (sabedoria). Acrescentando-se a eles dai (grande) e shô (pequeno), formavam-se daitoku (grande virtude) e shôtoku (pequena virtude), daijin (grande benevolência) e shôjin (pequena benevolência), e assim sucessivamente.

${ }^{79}$ Em japonês, Kenpô Jûshichijô, literalmente "Constituição de dezessete artigos". Ao longo do tempo, ele foi traduzido literalmente como "constituição" (Varley, 2000: 25; Sansom, 1987: 71, ver também nota 3). Entretanto, Kenpô Jûshichijô está longe do que consideramos constituição na atual acepção do termo,
} 
Artigo primeiro: devem-se valorizar a harmonia e a hierarquia;

Artigo segundo: deve-se respeitar o budismo;

Artigo terceiro: deve-se obedecer ao soberano;

Artigo quarto: deve-se ter a cortesia como base de comportamento;

Artigo quinto: deve-se ser imparcial no julgamento;

Artigo sexto: deve-se fomentar o bem e combater o mal;

Artigo sétimo: devem-se cumprir as obrigações do seu ofício;

Artigo oitavo: deve-se chegar cedo à sua repartição e voltar tarde;

Artigo nono: deve-se observar que a credibilidade é a base da justiça;

Artigo décimo: deve-se conter a ira;

Artigo décimo primeiro: deve-se premiar e punir os oficiais de acordo com êxito e fracasso, respectivamente;

Artigo décimo segundo: os governantes ${ }^{80}$ não devem cobrar impostos injustos dos camponeses;

Artigo décimo terceiro: os oficiais devem estar a par de seus ofícios, assim como de seus colegas e subordinados;

Artigo décimo quarto: deve-se evitar ter ciúmes;

Artigo décimo quinto: devem-se afastar sentimentos e interesses pessoais;

Artigo décimo sexto: deve-se empregar o povo considerando a época e estações; Artigo décimo sétimo: não tomar decisões isoladamente, discutir com os demais para deliberação.

de modo que Suzuki traduz como "ordenação dos dezessete artigos" (2003: 87). No presente trabalho, optou-se por código, mais próximo do original, por considerar mais adequado ao seu conteúdo.

${ }^{80}$ Refere-se a kuninomikotomochi, que posteriormente se torna kuninomiyatsuko. 
É importante observar que o "Código de 17 Artigos" pressupõe três estratos sociais, o soberano [Kimi], os oficiais [shin] e o povo [min], sendo que o código em si foi elaborado para os oficiais (Kumagai, 2001: 234). Dessa forma, o efeito esperado por parte dos mandatários do governo de Yamato era que o código servisse de manual de conduta para os oficiais.

Em 645, após o golpe de Estado que derruba os Soga do poder, é adotada uma série de medidas, que ficaram conhecidas como Reforma de Taika, sendo duas as principais:

a) extinção das comunidades [kuni] e sedes administrativas [miyake]; estabelecimento de distrito [kôri]: como visto anteriormente, embora nomeado pelo governo central, o administrador local [kuninomiyatsuko] exercia, de fato, o poder na unidade administrativa, pois a maioria era chefes de clãs regionais que entraram em acordo com os mandatários de Yamato. Pela reforma, além de promover divisões e fusões de territórios, estabelecendo áreas menores do que a coumunidade, foram nomeados dois administradores para cada distrito, que eram originários de clãs diferentes. Dessa forma, o governo de Yamato pretendia evitar que um só clã monopolizasse o poder dentro de um território;

b) extinção dos grupos profissionais [be e $\left.k a k i^{81}\right]$ : conforme visto anteriormente, os grupos profissionais eram todos súditos do soberano, mas ao mesmo tempo eram subordinados aos principais clãs. Com o tempo, cada vez mais o be passou a representar os interesses dos clãs, trazendo uma série de problemas, como disputa com o be de outros clãs, tráfico de influências e

\footnotetext{
${ }^{81}$ Cf. item 3.4.
} 
corrupções. O intuito dessa medida era acabar com esses problemas e reduzir, ao mesmo tempo, a influência dos clãs no governo central.

De um modo geral, o objetivo dessas medidas era centralizar o poder e fortalecer o governo central, sob o comando do soberano. No caso do be, é digno de nota que antes da reforma, o custo com sua alimentação e outras necessidades era bancado pelo clã de origem, o que, naturalmente, reforçava a identificação e a sujeição ao clã. Após a reforma, o governo passou a bancar esses custos, dando um passo importante para tornar os cargos públicos, de fato, e consolidar o aparato administrativo do Estado.

Nesse sentido, em 649, a "ordenação de 12 posições hierárquicas" é ampliada para 19, e em 664, para 26, diversificando a hierarquia dos oficiais do governo. Ainda, em 664, o governo classifica os clãs em três categorias: "grande clã" [ôuji], "pequeno clã" [kouji] e "burocratas e outros" [tomonomiyatsukotô], e ordena que cada clã indique um representante oficial. Este representante era denominado "líder do clã" [ujinokami], e em sinal de reconhecimento, recebia armas diferentes: uma espada grande (ôji), uma espada pequena (kouji) e arco, flecha e escudo (tomonomiyatsukotô).

Em 670, sob a ordem do imperador Tenji, é realizado um censo populacional, em que se registra o nome, idade e grau de parentesco dos indivíduos, o chefe de família, além de estabelecer o sobrenome. Assim, nesse período, todas as pessoas passam a possuir sobrenome, com exceção do imperador e dos escravos (Kumagai, 2001: 318). 
3.6- Ritsuryôkokka - o Estado legista ${ }^{82}$

Em 673, sobe ao trono o imperador Tenmu (? - 686), que toma uma série de medidas e marca o início da implantação do chamado Ritsuryôkokka ${ }^{83}$ - Estado legista, inspirado no sistema chinês. As principais medidas tomadas podem ser assim resumidas (Watanabe, 2001: 12-18): estabelecimento da sede do governo em Asuka ${ }^{84}$; criação de estrutura burocrática do governo, com seleção de oficiais tendo como critério a meritocracia e não a origem de nascimento; extinção da diferenciação pela cor da "coroa"; estabelecimento das novas unidades regionais administrativas denominadas províncias $\left(k u n i^{85}\right)$, fundindo alguns distritos criados na Reforma de Taika; essas unidades passaram a ser governadas por administradores enviados pelo governo central, denominados kuninomikotomochi. Essa medida entrou em vigor por volta de 676, e as fronteiras de cada unidade foram estabelecidas em 683.

Em 682, é determinado que tanto homens quanto mulheres que trabalham na corte devem amarrar seus cabelos e usar uma "coroa" preta. Em 685, a hierarquia passa a ser representada pela cor da vestimenta e a reverência de se ajoelhar no chão é substituída pela forma que se faz em pé, adotando-se, em todos os casos, o estilo chinês.

\footnotetext{
${ }^{82}$ Tradução nossa, tentando captar o significado de ritsuryô, literalmente "código penal e administrativo". A bibliografia do Ocidente tende a manter a palavra sem tradução, como ritsuryô codes ou empregar legal codes ou codes of laws and ethics.

${ }^{83}$ Esse código era composto por duas partes: Ritsu, que estabelecia as penalidades, constituindo o que entendemos atualmente por código penal, e Ryô, que regia sobre a organização governamental, sobre o trabalho dos oficiais do governo, assim como ditava sobre as regras de taxação e relação de trabalho dos homens comuns. Kokka significa "estado".

${ }^{84}$ Situa-se na atual cidade de Nara. Nesse período, cada imperador que subia ao trono governava no palácio de origem ou mandava construir uma nova sede, fazendo assim, na prática, que a sede administrativa fosse itinerante. Esse estado continua até 694, quando fica pronto o Fujiwarakyô, que se torna sede administrativa permanente.

${ }^{85}$ Embora sejam palavras homófonas, nota-se que é diferente daquela que designava as comunidades, no século $\mathrm{V}$, sendo que, agora, significa unidade administrativa.
} 
Em 684, é implantado o sistema de "Oito Títulos" ${ }^{86}$ : os títulos até então existentes (omi, muraji, kimi, miyatsuko, atai, obito, fuhito etc) são reorganizados tendo como critério a proximidade com a família imperial, e classificados em oito: mahito, ason, sukune, imiki, michinoshi, omi, muraji e inagi.

A consolidação do Estado legista ocorre em três momentos importantes. O primeiro, em 689, quando entra em vigor o Código Asukakiyomihara ${ }^{87}$, cujas medidas são postas em prática, aos poucos, a partir de 690. O segundo, quando é promulgado o código que ficou conhecido como Código de $\operatorname{Taiho}^{88}$, em 701. O terceiro é quando o chamado Código Yôrô entra em vigor em 757, visando a complementar aquele de 701.

Essas leis estabeleceram o formato do arcabouço político e jurídico do Estado, além da organização social e a categorização dos indivíduos, cujas características principais podem assim ser resumidas:

a) organização do governo em conselho administrativo [daijôkan], tendo oito ministérios [shô] subordinados, e o conselho religioso [jingikan], que regia as cerimoniais religiosas e os santuários; o conselho administrativo era formado por ministros daijôdaijin, sadaijin, udaijin e dainagon, com secretariado, e seção que tem como atribuição fazer contato com as províncias e outros contatos regionais; cada ministério era dividido em subunidades administrativas, comandadas por oficiais dispostos em quatro categorias;

\footnotetext{
${ }^{86}$ Em japonês, yakusa no kabane.

${ }^{87}$ Segundo Amino, teria sido esse código a estabelecer, formalmente, a denominação Nippon, em substituição a Wa (2000: 88). Recentemente, essa tese passou a ser contestada, fundamentada em estudos de registros antigos; a maioria dos pesquisadores passa a defender o Código de Taihô (701) como o marco dessa mudança (Yoshikawa, 2011: 51-2).

${ }^{88}$ A denominação se originou da era Taihô, sendo primeiro ano o ano de 701, quando entrou em vigor o código.
} 
b) os indivíduos comuns eram identificados pelo pertencimento a uma grande família de organização patriarcal [ko ou gôko], que podia agregar ainda dependentes não consanguíneos [kikô] e servos [nuhi]. A cada seis anos, era realizado um censo com que se elaborava o documento de identificação civil [koseki] que continha informações de cada indivíduo, como idade e sexo, sobre o seu pertencimento a uma família, seu status social, etc. Baseando-se nessas informações, o governo convocava o indivíduo para serviços sociais e militares, pagamento de tributos etc. A distribuição de terras para o cultivo e desbravamento também era realizada tendo como base os dados do koseki;

c) com relação ao status social, os indivíduos eram classificados em duas categorias:

-“bons homens" [ryômin]: constituía essa categoria o estamento dominante, como membros da família imperial e dos clãs, os agricultores denominados kômin, e os artesãos semi-livres como tomobe e zakko;

-"homens de segunda categoria" [senmin]: eram os servos classificados em cinco categorias, a saber, ryôko (guardiães do túmulo imperial), kanko e kunuhi (kannuhi) (servos empregados em serviços oficiais), kenin (yakahito) e shinuhi (servos que prestavam serviços para os senhores, portanto, de caráter privado) ${ }^{89}$

\footnotetext{
${ }^{89}$ Além dessas diferenças, havia o fato de que kanko e kenin podiam formar o ko, não eram vendáveis e a condição de servo se restringia a si próprio, enquanto kunuhi e shinuhi não eram registrados no ko, ou seja, não eram independentes, a condição servil se estendia a todos os familiares e eram passíveis de serem comercializados como bens ou herdados como herança. Assim, verifica-se que esses últimos eram escravos, no sentido em que entendemos o termo.
} 
d) os detentores dos títulos mahito, ason, sukune, imiki, do sistema de "Oito Títulos", são ordenados em cinco graus ${ }^{90}$ que constituem a nobreza civil do Estado. Os portadores de outros títulos são colocados em postos administrativos, ordenados em dezesseis graus ${ }^{91}$.

Esse sistema político-administrativo consolida o poder central e torna-se o emblema do Japão Antigo.

Em 710, a capital é transferida para Heijôkyô, cidade governamental projetada para tal finalidade, iniciando o período que os historiadores denominam período Nara (710-784). Esse período é marcado pela ascensão do clã Fujiwara, no plano político, e pela expansão do budismo, no plano religioso, marcado pela inauguração da grande estátua de Buda, de cerca de 16m de altura, em 752.

\section{7- Regência e tomada do poder pela nobreza}

Após um breve intervalo de dez anos, período em que a sede administrativa situou-se em Nagaokakyô, antes que esta fosse concluída, em 794, a capital passa a ser Heiankyô (Ami, 2011), iniciando a fase histórica denominada período Heian (7941192).

Nesse período, a maioria dos compromissos assumidos entre os clãs na consolidação do Estado legista enfraquece, em meio a intensas disputas pelo poder,

\footnotetext{
${ }^{90}$ Do primeiro ao terceiro grau, havia duas categorias para cada grau (por exemplo: sei-ichii e jû-ichii), e do quarto ao quinto, quatro (por ex.: sei-yon'i jô e sei-yon'i ge, jû-yon'i jô e jû-yon'i ge), totalizando quatorze degraus hierárquicas (Osumi, 2001: 51).

${ }^{91}$ Consta que até o século VIII, nos palácios administrativos, somente os portadores do título acima de cinco graus tinha direito a cadeira para trabalhar, sendo que os demais sentavam numa espécie de esteira.
} 
sobretudo na conquista do trono do imperador. Assim, aos poucos, esse esquema de poder que tinha como base o pacto entre os clãs foi substituído por uma estrutura que privilegia a ligação política e pessoal com o imperador. Dessa forma, passam a fazer parte da estrutura de poder os letrados, principalmente nos assuntos sobre a China, e os burocratas de destaque, que passam a ser nomeados para os cargos de confiança do imperador.

Do final do século IX a meados do século XI, é o período que constitui a fase de política dos regentes $^{92}$, tendo como personagem principal o clã Fujiwara, que já ascendera no século VIII, como visto anteriormente, e que agora vê seu auge no domínio da política do Japão Antigo.

A política dos regentes foi exercida tendo como base a estrutura do Estado legista, principalmente o daijôkan ${ }^{93}$, que cuidava do dia a dia da administração, mas era o regente que detinha o poder sobre o reconhecimento de títulos [joi] e nomeação de cargos [jimoku]. Dessa forma, ao longo do tempo, o poder do Estado passa a se concentrar no estamento da nobreza formada por familiares do imperador e dos sucessivos regentes.

3.8- Ascensão dos guerreiros - bushi

Estes, para dirigir palavras ou cumprimentar os primeiros, ajoelhavam-se encostando a cabeça no chão (Osumi, op. cit., 53).

92 O denominado sekkan, palavra composta pela primeira letra de sesshô e kanpaku. O primeiro governava em nome do imperador quando este era menor, ou no seu impedimento por doença, enquanto o kanpaku assessorava o imperador adulto. Na maioria das vezes, aquele que era sesshô passava a ocupar o cargo de kanpaku, quando o imperador atingia a maioridade, razão pela qual, muitas vezes, não se faz distinção entre esses dois cargos.

${ }^{93}$ Cf. item 3.6. 
No início do século X, o Estado legista se encontrava em declínio, sobretudo pela incapacidade de arrecadar recursos, via cobrança de tributos, suficientes para manter a estrutura administrativa centralizada.

A solução proposta foi a descentralização. Os agentes enviados pelo governo central [kokushi] tiveram maior autonomia, passando a administrar as unidades territoriais [kuni]. Surge assim a figura de zuryô, que se comprometia a pagar uma determinada quantia de tributo para o governo central, em troca de autonomia para a exploração das terras como se fossem suas propriedades. As terras foram divididas em unidades denominadas myô, que eram por usa vez oferecidas para os camponeses [tato] que as exploravam em troca de pagamentos de tributos e serviços prestados, agora para o zuryô. Assim, muitos zuryô se enriqueceram, e na segunda metade do século XI, um número considerável deles residia em Quioto, deixando a administração direta a cargo do administrador local [zaichôkanjin], escolhido e nomeado muitas vezes entre os capacitados do clã local.

Entre as propriedades assim exploradas, havia o latifúndio privado, denominado shôen. A origem do shôen remonta ao século VIII, quando os nobres e monges de grandes templos desbravaram as terras e tomaram posse delas; entretanto, a tributação imposta e a dependência ao Estado acabaram por inviabilizar economicamente a maior parte deles, entrando em declínio no século IX. Agora, com a política de descentralização, muitos shôen ficaram isentos da tributação, e aproveitando-se desse privilégio, expandiram-se. O sistema de exploração era a base para constituição da hierarquia desses latifúndios: os dominantes, que recolhiam os tributos, e os dominados, que pagavam tributos (Fukushima, 2011: 18).

É dentro desse contexto que surgem os chamados guerreiros - bushi. A origem dos guerreiros é atribuída a duas correntes, o tsuwamono, regional, e bushi propriamente 
dito, dos setores próximos à corte. Os denominados tsuwamono se tratam de clãs regionais e camponeses bem sucedidos que se armaram com espada, arco e flecha, e se tornaram cavaleiros para aumentar e garantir o domínio regional. O bushi também tem origem nos clãs, mas oriundos das regiões próximas da capital, que, armados, passaram a prestar serviços à corte e aos nobres, servindo de guarda-costas dos palácios e da capital. Essas duas correntes se uniram principalmente nas regiões periféricas do Estado, constituindo um grande grupo de contingentes armados, denominado bushidan. (Sato et al., 2008: 114). Aos poucos, além de travar batalhas entre si, os guerreiros começam a se rebelar, desafiando a autoridade do administrador local [kokushi] ou o poder central, sendo considerado representativo o episódio que ficou conhecido como a rebelião de Masakado (939) que, após dominar uma boa parte da região denominada Tôgoku ${ }^{94}$, se autointitulou "novo imperador". A rebelião de Masakado foi neutralizada por Taira no Sadamori (?-?), antes da chegada da tropa da corte. Na mesma época, também teve o levante de Fujiwara no Sumitomo (? - 941), na região oeste do arquipélago, e ambos incidentes serviram para destacar o poderio dos guerreiros, assim como para mostrar o prenúncio da nova fase histórica.

A partir de então conhecedores da capacidade dos guerreiros, a corte e os nobres procuraram incorporar os bushi ao aparato do Estado, sob a denominação de samurai. Muitos foram destacados para servir ao kokushi, na condição de kunizamurai ou tachizamurai, enquanto outros foram nomeados tsuibushi, encarregado de perseguir e prender os marginais e rebeldes, ou ôryôshi, comandantes das tropas de repressão de rebeliões.

\footnotetext{
${ }^{94}$ Atual Kantô, região de Tóquio e adjacências.
} 
O estamento bushi se desenvolve ao longo dos séculos X a XI, como profissionais de guerra, e se consolida pelas peculiaridades que vão caracterizá-lo como tal ao longo da história do Japão, com incremento de armas, estabelecimento de formas de treinamento e transmissão de "arte de guerra" para as gerações seguintes, assim como pelo controle das vias locais de transporte e circulação de pessoas e de bens, constituindo o domínio da localidade como seu território (Tanaka, 2011: 13). Aos poucos se organizam em clãs, tendo como cabeça aqueles considerados pertencentes à linhagem da nobreza central, denominados buke, nobreza militar, e surge uma relação de subordinação entre os bushi, que os historiadores ocidentais descreveram como relação de vassalagem. Dois deles se destacaram em meio a disputas entre os membros da família imperial, ora apoiando, ora se opondo a um deles: Taira (Heishi ou Heike) e Minamoto (Genji).

Os primeiros a chegar ao poder foram os Taira, cujo mandatário Kiyomori implanta um regime autoritário em 1179 , usurpando o poder pela força ${ }^{95}$. Entretanto, vários clãs regionais recusam o domínio dos Taira, iniciando levantes que culminam em sucessivas guerras, que duram cinco anos. Os Taira são derrotados pela confederação liderada por Minamoto no Yoritomo, em 1185, que vai implantar o primeiro xogunato, regime militar por excelência.

\footnotetext{
95 Entretanto, os Taira não modificaram a estrutura do Estado, ou melhor, não tiveram tempo para tanto, ficando dependentes do sistema antigo, o que, em parte, contribuiu para sua derrocada.
} 
3.9- Domínio e estabelecimento da sociedade dos guerreiros

Os Minamoto resolveram fazer da cidade de Kamakura ${ }^{96}$ seu reduto, a sede da administração do novo regime de xogunato [bakufu ${ }^{97}$, comandado pelo estamento de guerreiros, ou melhor, pela nobreza militar [buke], que chegara ao poder pela imposição das armas, pelo domínio da força militar.

A estrutura do novo Estado foi implantada, sendo que sua arquitetura já havia sido iniciada em 1180, com o estabelecimento do samuraidokoro, corporação que visava a organizar e comandar os gokenin, os guerreiros que seguiram a liderança dos Minamoto. Em 1184, foram criados kumonjo, posteriormente denominado mandokoro, encarregado da administração geral e de finanças, e monchûjo, cujas atribuições equivaleriam ao que conhecemos atualmente por poder judiciário. Em 1185, Minamoto no Yoritomo consegue obter da corte imperial o direito de nomear o administrador de províncias [shugo], o administrador de latifúndios privados ${ }^{98}$ e de terras públicas [jitô]. Nesse quesito, é importante observar que mesmo Yoritomo precisava da formalização da corte imperial para governar. Em outras palavras, a corte imperial era a única fonte legitimadora do poder, o que vai prevalecer ao longo dos regimes comandados pelos guerreiros. Em 1192, Yoritomo é nomeado Seii-daishôgun, "generalíssimo combatente dos povos bárbaros" ${ }^{\prime 99}$, ou abreviando, shogun ${ }^{100}$, o mais alto patente que um bushi pode receber $^{101}$.

\footnotetext{
${ }^{96}$ Situa-se na província de Kanagawa, vizinha a Tóquio.

${ }^{97}$ Palavra de origem chinesa, bakufu significa, literalmente, cortina de pano e designava a central de comando cercada de cortina, de onde o general, shogun, comandava na guerra. No Japão, passou a ser empregado para designar o palácio do xogum. A acepção de governo comandado por bushi é criação posterior, não tendo esse sentido no período aqui retratado (Sato et al., 2008: 134).

${ }_{98}$ Chamado shôen. Cf. item 3.8.

${ }^{99}$ Era um título dado, inicialmente, para o comandante da tropa que se dirigia para o nordeste do Japão para combater os emishi, povos que não se subjugavam ao domínio de Quioto, sendo por isso considerados bárbaros e rebeldes. A partir de Yoritomo, passou a designar o comandante máximo dos samurais.
} 
Para o jitô, foram nomeados os vassalos [gokenin] de Yoritomo. Para esses, essa nomeação significava a garantia de continuar explorando as terras que foram desbravadas pelos seus antepassados, garantia esta que era, até então, frágil, devido à cobiça e disputa com a vizinhança, assim como pela interferência dos agentes enviados pela corte imperial. Em troca, os vassalos batalhavam pela tropa do xogum na guerra, e no período estável, formavam o corpo de segurança e se encarregavam da proteção do xogunato [kamakura ban'yaku] ou da corte [kyôto ôbanyaku]. Todo o custo ficava por conta do próprio gokenin, o que consistia um pesado encargo. Dessa forma, surge a relação de subordinação/dominação baseada na concessão de terras e institucionalizada no nível do Estado, que constituiu o chamado feudalismo japonês.

Vale ressaltar que, nesse período, o poder da corte, que formalmente ainda nomeava os governantes locais, assim como dos nobres e monges que possuíam grandes extensões de terras [shôen] prevaleciam, coexistindo com o pacto entre os samurais e o xogum. Dessa forma, era comum um gokenin possuir mais de um "senhor", de acordo com a conveniência do momento e da ocasião. Essa coexistência de duas forças, tendo o imperador como centro, por um lado, e os Minamoto, do outro, era fonte de tensão constante, que se amplia cada vez mais nos séculos seguintes.

Com a morte de Yoritomo, em 1199, inicia a era do domínio do clã Hojo, que governa de fato na condição de regente do xogum, denominado shikken ${ }^{102}$.

Em 1232, é estabelecido o Código de Conduta dos Guerreiros [goseibaishikimoku]. Composto por 51 artigos, esse código regia sobre os julgamentos

\footnotetext{
100 Essa palavra foi incorporada ao léxico do português com a grafia "xogum", e será adotada na sequência do presente trabalho.

${ }^{101}$ Por esse motivo, tradicionalmente, o ano de 1192 é considerado o início do período Kamakura, embora haja controvérsias a respeito, por exemplo, alguns historiadores defendem o ano de 1180, quando Yoritomo se estabelece em Kamakura, ou 1185, quando adquire poderes políticos de fato.

${ }^{102}$ Yoritomo deixou um herdeiro de dezoito anos, Yoriie, que adoece em 1203, abrindo espaço para a disputa entre os que defendem Ichiman, seu primogênito, e aqueles que querem o Senman, segundo filho,
} 
referentes ao governo, assuntos de natureza civil e penal, baseando-se em direito consuetudinário, tendo como referência a jurisprudência da época de Yoritomo. Na prática, esse código veio para formalizar os valores e as condutas praticados pelo estamento guerreiro, estranho aos fundamentos do legismo. Com o domínio cada vez crescente dos guerreiros, o código dos guerreiros passa a ter importância cada vez maior, sem anular, entretanto, o código da nobreza [kugehô] e o código observado em latifúndios privados [honjohô], portanto, local, ambos inspirados no código legista [ritsuryô]. Dessa forma, o código dos guerreiros vai ocupar paulatinamente a lacuna deixada pelo enfraquecimento do legismo que, nessa época, muitas vezes, já era ignorado até pelos setores da corte imperial.

Em parte em decorrência da crise econômica causada pela luta contra os mongóis, que tentaram invadir o Japão por duas vezes, em 1274 e 1281, o xogunato de Kamakura entra em declínio no início do século seguinte. Após um interregno de governo liderado pelo imperador Godaigo, entre 1333 e 1336, um novo xogunato, de Muromachi ${ }^{103}$, é estabelecido por Ashikaga Takauji, em Quioto. No final do mesmo ano, em 1336, o imperador Godaigo se estabelece em Yoshino e declara a Corte Sul (Nanchô), em contraposição à Corte Norte (Hokuchô), em Quioto, cujo imperador, Kômyô, apóia o xogunato de Muromachi. É o período histórico denominado Período das Cortes Norte e Sul [Nanbokuchôjidai], que dura até 1392.

O xogunato de Muromachi manteve, na essência, a mesma estrutura de dominação do regime de Kamakura, chamando para os postos chaves os súditos de

como herdeiro do xogun. Vence o segundo, que assume como Minamotono Sanetomo, com apenas doze anos.

${ }^{103} \mathrm{O}$ nome Muromachi vem da denominação da localidade de Quioto, onde o terceiro xogum do regime, Yoshimitsu (1358-1408), inaugurou o Palácio das Flores (Hana no Gosho) em 1378. Para alguns 
confiança. No governo central, foi criado o cargo de conselheiro do xogum [kanrei], o único cargo que respondia diretamente ao $\operatorname{xogum}^{104}$, e que comandava os principais órgãos como samuraidokoro e mandokoro, criados no regime de Kamakura.

O domínio das regiões também foi feito via nomeação de administradores [shugo], mas agora com maiores poderes e atribuições, inclusive de executar a ordem judicial na condição de representante do xogunato. A partir de 1368, os administradores passaram a ter o direito de se apoderar e distribuir as grandes terras, shôen, com exceção de alguns pertencentes ao imperador, à nobreza e aos monges. Dessa forma, pela oferta de terras, os administradores foram estendendo seus poderes, incorporando os samurais sob seus domínios. Eles passaram a exercer esse direito de forma hereditária, mantendo o poder da família. Os principais administradores passaram, ao longo do tempo, a nomear seu substituto, shugodai, que na sua ausência administrava seu território. Surge assim a figura de administradores daimiô [shugo daimyô], que se torna um dos personagens principais do regime de Muromachi (Hayashima, 2010).

Havia, entretanto, os samurais que se recusavam a prestar fidelidade ao shugo, assim como aqueles que mantinham devoção direta ao xogum. Esses eram denominados kokujin, que se aliavam para, por um lado, manter o domínio sobre os camponeses, e, por outro, resolver os conflitos e se contrapor aos administradores nomeados pelo xogunato.

São essas figuras do final da era Muromachi, o shugo, o shugodai e o kokujin, cada qual defendendo seus interesses e ampliando seus domínios, que vão formar o chamado sengoku daimyô ${ }^{105}$, ou "senhor do Período de Guerras"106.

historiadores, a rigor, o regime deveria denominar-se xogunato de Quioto, se se empregar o mesmo critério de xogunato de Kamakura e de Edo (1603-1867).

${ }^{104}$ Membros de três clãs de confiança dos Ashikaga, os Shiba, Hosokawa e Hatakeyama, passaram a se revezar no cargo. 
No final do século XVI, disputas internas no próprio clã Ashikaga haviam minado a base do regime de Muromachi, e são justamente esses senhores da guerra que vão aparecer no cenário, como novos protagonistas.

\subsection{0- Daimiôs de guerra e o Período Edo (1603 a 1868)}

Nos meados do século XVI, os principais daimiôs ocupavam quase a totalidade do arquipélago, com exceção da ilha setentrional de Hokkaido, sendo os principais os Uesugi, Takeda, Oda, Imagawa e Hôjô na região central, Miyoshi na região de Kinki, ou seja, Quioto e adjacências, e Môri na região oeste e parte da ilha de Kyûshû.

O primeiro a se destacar foi Oda Nobunaga (1534-82), filho de súdito do shugodai de Owari ${ }^{107}$, que após derrotar o próprio shugodai, torna-se daimiô. Em 1560, derrota Imagawa Yoshimoto (1519-60), daimiô da região de Suruga e Toutoumi ${ }^{108}$, e amplia seus domínios.

Em 1573, após vencer a tropa da confederação dos Asai e Asakura, aliada do regime de Muromachi, Nobunaga toma a capital Quioto, expulsa o décimo quinto xogum Yoshiaki e põe fim ao período Muromachi. Entretanto, em 1582, após derrotar

\footnotetext{
${ }^{105}$ Assim como xogum, essa palavra também foi incorporada ao léxico do português, sob grafia "daimiô", e será adotada na sequência do trabalho.

${ }^{106}$ Em japonês, sengoku jidai, período em que poderosos daimiôs batalharam entre si por um século, visando à ampliação de território e poderes políticos. Os historiadores atribuem o seu início ao conflito de Ônin, iniciado pela disputa de sucessão no clã Ashikaga, em 1467, dividindo os daimiôs em duas tropas, do Leste, com 160 mil samurais de 24 territórios, e do Oeste, com 110 mil samurais de 20 territórios. O conflito durou onze anos, devastando a cidade de Quioto, e a sua maior consequência foi ter ampliado a escala de batalha, até então reduzida, para um nível que envolveu vários territórios e milhares de soldados.

${ }^{107}$ Situava-se na atual província de Aichi.

${ }^{108}$ Atual província de Shizuoka.
} 
os Takeda ${ }^{109}$ e no caminho para a batalha contra os Môri ${ }^{110}$, Nobunaga é traído e assassinado por um de seus súditos.

Quem sucedeu Nobunaga e concluiu a unificação do arquipélago foi Toyotomi Hideyoshi (1537? - 98). Originário de Owari e filho de um samurai de baixa patente, Hideyoshi galgou posições como um dos principais súditos de Nobunaga. Após a morte deste, assumiu o vácuo deixado, colocando sob seus domínios a atual ilha de Shikoku em 1585, a ilha de Kyûshû, em 1587, e a atual região nordeste (Tôhoku), em 1590. Ao mesmo tempo, Hideyoshi não se omitia em buscar legitimidade junto à corte imperial, sendo nomeado conselheiro [kanpaku ${ }^{111}$, em 1585.

Uma das principais medidas tomadas por Hideyoshi foi a chamada "apreensão de espadas" [katanagari]. Implantado em 1588, essa medida proibia que a população não-samurai portasse espadas e outros tipos de armamentos, e isso tinha como objetivo desarmar os contingentes camponeses, denominados hyakusho ${ }^{112}$, fortemente armados e focos de tensão, principalmente aqueles lotados em latifúndios privados, e obrigá-los a se dedicar apenas à lavoura e atividades afins. Dessa forma, portar ou não a espada passou a ser símbolo de status de samurai.

Em 1591, Hideyoshi decreta um código de status, o hitobarairei, composto por três artigos: o primeiro proibia que o súdito da nobreza militar [bukehôkônin], ou seja, o samurai, se tornasse um citadino $\left[\right.$ chônin $\left.^{113}\right]$ ou camponês [hyakushô]; o segundo proibia que o camponês se tornasse comerciante ou artesão; o terceiro proibia que o samurai trocasse de senhor. No ano seguinte, em 1592, foi realizado o censo para

\footnotetext{
${ }^{109}$ Daimiô que dominava Kai, atual província de Yamanashi, e adjacências.

${ }^{110}$ Originário de Aki, atual província de Hiroshima, dominou uma boa parte da região oeste da ilha de Honshû, além da uma parte do norte da ilha de Kyûshû.

${ }_{111}$ Cf. nota 92.

${ }^{112}$ Historicamente, o termo hyakushô era considerado sinônimo de agricultor, mas a partir da década de 90, as pesquisas mostraram a heterogeneidade de atividades que esse contingente campesinato desenvolvia. Ver principalmente Amino, 1994.

${ }^{113}$ Contingente não-samurai que residia nas cidades, como comerciantes e artesãos.
} 
quantificar o número de cada estamento e, assim, foi oficializado o status de cada um, nobreza militar, citadino e camponês.

O domínio dos Toyotomi teve curta duração, e a mal sucedida incursão à península coreana, realizada em dois momentos, em 1592 e 1597, agravou as finanças do regime, antecipando o seu fim. Hideyoshi falece em 1598.

Tokugawa Ieyasu (1542-1616), outrora súdito de Nobunaga e um dos daimiôs de destaque sob o comando de Hideyoshi, assume o poder após vencer a confederação dos daimiôs do Oeste, na batalha decisiva de Sekigahara, em 1600. Em 1603, Ieyasu é nomeado xogum, e implanta o xogunato de Edo, em Edo, atual cidade de Tóquio. Em 1605, para demonstrar que o xogum será hereditário, Ieyasu abdica ao título a favor do filho Hidetada (1579-1632), se autonomeia ôgosho e se retira para Sunpu, sem, no entanto, abrir mão do poder, na prática. Em 1615, derrota os remanescentes dos Toyotomi em Osaka, e consolida a hegemonia dos Tokugawa, que vai durar cerca de três séculos.

Uma das primeiras medidas tomadas pelo xogunato de Edo, após a vitória sobre os Toyotomi, em 1615, foi proibir que um feudo tivesse mais de um castelo, medida denominada "ordem de um castelo por feudo" [ikkoku ichijôrei]. Essa medida tinha como objetivo delimitar a força dos daimiôs, enfraquecendo-os, para evitar futuras possibilidades de rebelião. Também emitiu o código da nobreza militar [bukeshohatto], cuja principal determinação era oficializar os daimiôs como governantes de cada feudo denominado han, embora a fidelidade ao xogum, relação esta de cunho pessoal, fosse a fonte legitimadora, na essência.

A estabilidade política do xogunato de Edo foi alcançada pelas medidas tomadas pelos três primeiros xoguns. O terceiro xogum Iemitsu (1604-51), sucessor de Hidetada, 
decreta, em 1635, a obrigação do sankinkôtai, medida em que obriga os daimiôs a permanecerem lotados por um ano em Edo, para prestar serviços de segurança e outros, como de apagar fogo em caso de incêndio. Essa medida obrigava os daimiôs a possuir palácio em Edo, mantendo nele suas esposas e filhos, além de ter de arcar com altas despesas para a locomoção entre o feudo e a capital. Essa política tinha como objetivo minar tentativas de subversão, já que os familiares residentes em Edo serviriam, em última instância, como refém por parte do xogunato, além de asfixiar financeiramente os feudos para evitar acúmulo de divisas que pudessem ser empregadas para tal finalidade.

É nessa época, também, que a estrutura de governo do xogunato de Edo se consolida, tendo como principais cargos o rôjû, ocupado por quatro membros, que constituía o cérebro do regime, wakadoshiyori, também composto de quatro membros, tendo como função auxiliar o rôjû e comandar os hatamoto ${ }^{114}$, ômetsuke, com função de controlar os daimiôs, e metsuke, que controlava os hatamoto. Havia ainda o jishabugyô, encarregado de controlar os templos (quatro membros), kanjôbugyô, encarregados de administração e finanças (quatro membros), machibugyô, encarregado de gerir a cidade de Edo (dois membros).

O regime de Tokugawa manteve o princípio de distinção de status social, iniciado por Toyotomi Hideyoshi. Ao longo do período Edo, a tese corrente é a de que a sociedade era dividida em quatro estamentos, shi (de bushi), nô (de nômin, camponeses), kô (de shukô, artesãos) e shô (de shônin, comerciantes), embora, na realidade, apresentasse uma complexidade suficiente para refutar essa tese simplista.

Os setores dominantes eram os bushi, em primeiro lugar, além da família imperial, os nobres e o alto clero, incluindo os monges budistas e sacerdotes xintoístas.

\footnotetext{
${ }^{114}$ Eram os súditos diretos do xogum, sem pertencer a nenhum han.
} 
O estamento bushi governava de fato, monopolizando o uso da força e ocupando a máquina governamental. Possuía privilégios como o direito de portar armas, de possuir sobrenome e outras distinções, como vestimentas e corte de cabelo, peculiares. Como visto anteriormente, possuía rígido sistema de hierarquia tendo no topo o xogum (ou ôgosho, em alguns momentos), seguido por outras classes guerreiras subordinadas: daimiô, hatamoto, gokenin, baishin, bukehôkônin etc. Entre os daimiôs, a hierarquia era estabelecida pelo tamanho do feudo ${ }^{115}$, pela proximidade com o xogum ${ }^{116}$, pelo porte de título conferido pelo imperador, etc. Em atos oficiais, o assento era estabelecido de acordo com a hierarquia, assim como a obrigação de se vestir adequadamente. Da mesma forma, a nobreza e o clero apresentavam uma estrutura hierárquica rígida, de acordo com o título.

Em contraste com o feudalismo do Ocidente, o feudalismo japonês se caracterizou pela tendência de a vassalagem predominar sobre o domínio feudal, ou seja, “o vínculo entre senhor e súdito era mais forte do que o vínculo econômico do servo à terra", e "o componente contratual da vassalagem era muito mais fraco" do que na Europa, por apresentar "caráter semifamiliar e sagrado do que legal" (Anderson, 1985: 437-8).

Os setores dominados pelos guerreiros eram constituídos por hyakushô, que ocupavam principalmente as atividades agrícolas, além de atividades florestais e pesqueiras; os shokunin, artesãos, como carpinteiros, marceneiros, ferreiros etc, cada qual com suas técnicas; e os shônin, comerciantes. Entre os hyakushô, também havia

\footnotetext{
${ }^{115}$ Era estabelecido de acordo com a produção de arroz, quantificado pela unidade goku. Cada goku equivalia a cerca de $150 \mathrm{Kg}$.

${ }^{116}$ No período Edo, os daimiôs eram classificados em três categorias: os shimpan, pertencentes ao clã Tokugawa; os fudai, que eram súditos dos Tokugawa antes da batalha de Sekigahara; e os tozama, aqueles que se tornaram súdito dos Tokugawa após essa batalha. Cf. Ikegami, 2002: 347 e ss.
} 
hierarquia social, como entre takamochi ou honbyakushô, que possuíam lavouras e pagavam tributos, e mizunomi, que prestavam serviços como diaristas para takamochi.

Abaixo desses, estavam os párias ${ }^{117}$, kawata ou chôri e hinin. Esses párias, kawata, da região Oeste do Japão, e chôri, da região Leste, além de trabalhar na lavoura, se encarregavam de cuidar do cadáver de animais. Os hinin residiam ou no campo ou nos cortiços das cidades, e trabalhavam com limpeza e em atividades de carcereiros e construção de cadeias, entre outras ${ }^{118}$.

3.11- O fim da era dos samurais e o advento da modernidade

O regime de Tokugawa durou cerca de duzentos e sessenta anos, e o seu último ato foi a contenda com os feudos rebeldes Satsuma, Chôshû e Tosa ${ }^{119}$, da qual saiu derrotado após intensas batalhas, que também envolveram ainda os feudos de $\mathrm{Aizu}^{120}$ e outros da região nordeste. A consequência foi a renúncia do décimo quinto xogum e a devolução do poder à corte imperial, em 1868, no episódio conhecido como Restauração Meiji. A ameaça da colonização do Japão por parte das grandes potências do Ocidente foi um fator que muito contribuiu para a mudança do regime, seja pela ineficiência do xogunato de reagir a essa situação, seja pela necessidade de modernizar o país, sobretudo belicamente, para dar conta dos novos desafios que ficaram evidentes a partir da chegada dos americanos, em 1853.

\footnotetext{
${ }^{117}$ Posteriormente denominados eta.

118 Esses párias já existiam, segundo os registros, já no período Muromachi. Para compreender sua condição de segregação e discriminação, é necessário levar em consideração a noção de kegare, "impureza" (Teraki, 2000: 53).

${ }^{119}$ Situavam-se, respectivamente, nas atuais províncias de Kagoshima, Yamaguchi e Kôchi.

${ }^{120}$ Atual província de Fukushima.
} 
O novo governo que se formou sob a liderança dos membros dos feudos rebeldes governou em nome do imperador e instaurou uma política de centralização política e administrativa. Ainda em 1868, renomeou a cidade de Edo como Tóquio e, em 1869, esta foi oficializada como a nova capital ${ }^{121}$. Ao longo dos anos de 1871 a 1873 , uma série de medidas foi tomada visando ao fortalecimento do governo central: a extinção dos feudos e instauração das províncias [ken], implantação do serviço militar, e a principal, a criação da nova estrutura de governo, que extinguiu o jingikan, incumbido da política religiosa, e que abaixo de dajôkan organizou três dietas: uin, com função executiva, sain, com função legislativa, e seiin, composto por dois ministros e um adjunto, que comandavam nove ministérios.

Uma notória transformação foi verificada na relação hierárquica, que constituía o cerne do regime dos samurais. Com a extinção dos feudos, de imediato desapareceu a relação de subordinação que existia entre o senhor e o suserano. Os quatro estamentos que constituíam o regime de Tokugawa foram assim reagrupados:

daimiôs e nobres [kuge]: kazoku

samurais (não-daimiôs): shizoku

agricultores, artesãos e comerciantes: heimin

Em 1871, o governo baixou um decreto de "libertação" dos párias, os hinin e os eta, extinguindo esses termos, e conferindo-lhes o status de cidadão comum [heimin $]^{122}$. Ainda, os heimin adquiriram o direito de ter sobrenome, de eventualmente casar-se com os membros do kazoku ou shizoku, e ainda de poder escolher livremente a ocupação ou o local de moradia. Posteriormente, pelo decreto de 1884, a "Lei da Nobreza"

\footnotetext{
${ }^{121}$ Note-se que durante o xogunato de Tokugawa, embora na prática a sede político-administrativa fosse Edo, oficialmente a capital continuava em Quioto, onde residia a corte imperial.

${ }^{122}$ Isto não quer dizer que de imediato a condição social dos párias foi reconhecida. Sobretudo na região oeste do Japão, a discriminação e o preconceito persistiram até os anos noventa do século passado.
} 
[Kazokurei], o kazoku foi divido em cinco categorias: kôshaku (“duque”), kôshaku" ${ }^{123}$ ("marquês"), hakushaku ("conde"), shishaku ("visconde") e danshaku ("barão"). Além dos antigos daimiôs e nobreza, receberam esses títulos os dirigentes do novo regime e políticos, ampliando consideravelmente o número de seus membros.

Em 1876, o porte de espada foi proibido, acabando com o privilégio dos samurais, expressando simbolicamente o fim da era dos guerreiros na historia do Japão.

3.12- Consolidação do Estado moderno e envolvimento nas guerras

Tendo como modelo países desenvolvidos como a Inglaterra, a França e os Estados Unidos, a democracia representativa foi implantada no Japão: em 1879, as Assembléias Provinciais [fukenkai], compostas de membros eleitos, são instaladas. Em 1881, é fundado o Partido Liberal [Jiyûtô], primeiro partido com abrangência nacional, seguido de Partido Constitucional Renovador [Rikken Kaishintô], fundado em 1882. Pela reforma do aparato governamental de 1885, o sistema que tinha o dajôkan no topo é substituído por um sistema de gabinete, comandado por um primeiro-ministro.

O marco da consolidação do Estado moderno japonês foi a promulgação, em 1889, da Constituição do Grande Império Japonês, ou Constituição Meiji, como é conhecida. Inspirada nas constituições dos países europeus como Prússia, Alemanha, Bélgica e Inglaterra, a Constituição Meiji foi outorgada e tinha como elemento principal o imperador que, além de chefe de Estado, tinha soberania sobre as três forças militares, poder de nomear os cargos do Executivo, de convocar e dissolver o Congresso, de

\footnotetext{
${ }^{123}$ São duas palavras heterógrafas, do ponto de vista do ideograma empregado: 公爵para duque e侯爵para marquês.
} 
promulgar as leis, etc., ou seja, o poder estava concentrado em suas mãos, embora o artigo $4^{\circ}$ o sujeitasse ao conteúdo da Constituição. As vicissitudes das relações sociais dessa fase histórica, cujas heranças ainda são visíveis na atualidade, são o objeto do capítulo seguinte.

O Japão venceu duas guerras ainda sob o imperador Meiji no trono: a Guerra Sino-Japonesa (1894-5), pela qual, vitorioso, anexou a ilha Formosa como colônia e a Guerra Russo-Japonesa (1904-5), que elevou o status do Japão como potência da Ásia, obtendo, entre outros, o direito de interferir no governo da Coreia ${ }^{124}$.

O imperador Meiji veio a falecer em 1912 e foi sucedido pelo imperador Taishô, que teve breve trono (1912-26). Em 1914, o Japão se envolve na Primeira Guerra Mundial ao lado dos aliados, que se tornaram vitoriosos, e tira proveito dessa aliança, principalmente econômico. Mas a quebra da bolsa de valores de 1920 e o grande terremoto que assolou a região de Kanto, em 1923, trazem a grande depressão econômica, cujas consequências acarretam o colapso da política dos partidos e abre o caminho para a ascensão dos militares e da extrema direita ao poder, na década seguinte.

O imperador Shôwa ${ }^{125}$, entronado em 1926, presenciou essa fase de radicalismos e conturbações, e o envolvimento e posterior derrota do Japão na Segunda Guerra Mundial. A sua participação e, sobretudo, a sua responsabilidade nessa série de acontecimentos da história contemporânea do Japão são motivos de acaloradas discussões ainda hoje, e marcou, de certa forma, a imagem do imperador entre o povo japonês, principalmente entre aqueles que participaram direta ou indiretamente da grande guerra.

\footnotetext{
${ }^{124}$ A anexação da Coreia veio a ocorrer somente em 1910.

${ }^{125}$ Conhecido popularmente como Hirohito, principalmente no Ocidente.
} 
Derrotado na guerra, o Japão esteve sob a ocupação dos aliados, tendo os americanos no comando, de 1945 a 1952 . Nessa fase, foram tomadas as medidas que tiveram grande impacto na sociedade japonesa, como a reforma agrária promovida em duas etapas, em 1946 e 1950, a reforma educacional, em 1947, e a promulgação da Lei Trabalhista, em 1945.

O início da Guerra Fria e principalmente a Guerra da Coreia (1950-53) favoreceram a reconstrução do Japão, que teve a economia reativada na condição de país fornecedor de materiais e serviços para os aliados. Em 1955, a economia japonesa já se encontrava num patamar superior àquele verificado antes da Segunda Guerra Mundial e, a partir de então, cresceu anualmente acima de $10 \%$ do PNB nas duas décadas seguintes (Sato et al, 2008: 497).

A prosperidade econômica fez surgir a sociedade de massas e de consumo no Japão, e é inegável que isso tenha repercutido na mudança das relações sociais entre os nipônicos. Esse reflexo será tema de estudo do Capítulo 5, no que se refere à concepção de "classe média", refletindo o sentimento de "igualdade" da população geral. Não obstante, o senso de hierarquia ainda estará presente nessa sociedade, nas instituições tradicionais como escola, como será examinado no capítulo correspondente.

\subsection{3- Considerações finais do capítulo}

Para Giddens, as sociedades podem ser classificadas em três tipos, de acordo com os princípios estruturais, definidos como "princípios de organização de totalidades sociais" $(1989: 152)^{126}$ :

\footnotetext{
${ }^{126}$ Tabela organizada de acordo com o esquema apresentado em Giddens, 1989, p. 148-9.
} 


\begin{tabular}{|c|c|c|c|}
\hline $\begin{array}{c}\text { tipos de } \\
\text { sociedade }\end{array}$ & princípios estruturais & $\begin{array}{l}\text { organização de } \\
\text { local dominante }\end{array}$ & características \\
\hline $\begin{array}{l}\text { sociedade tribal } \\
\text { (culturas orais) }\end{array}$ & $\begin{array}{l}\text { tradição } \\
\text { parentesco } \\
\text { sanções grupais }\end{array}$ & bandos ou aldeias & $\begin{array}{l}\text { fusão das } \\
\text { integrações social e } \\
\text { de sistema }\end{array}$ \\
\hline $\begin{array}{l}\text { sociedade } \\
\text { dividida em } \\
\text { classes }\end{array}$ & $\begin{array}{l}\text { tradição } \\
\text { parentesco } \\
*\left\{\begin{array}{l}\text { política - poder militar } \\
\text { interdependência }\end{array}\right. \\
\text { econômica (baixa) }\end{array}$ & $\begin{array}{l}\text { simbiose de cidade } \\
\text { e campo }\end{array}$ & $\begin{array}{l}\text { diferenciação das } \\
\text { integrações social e } \\
\text { de sistema }\end{array}$ \\
\hline $\begin{array}{l}\text { sociedade de } \\
\text { classes } \\
\text { (capitalismo) }\end{array}$ & $\left\{\begin{array}{l}\text { rotinização } \\
\text { parentesco (família) } \\
\text { fiscalização } \\
\text { política - poder militar } \\
\text { interdependência }\end{array}\right.$ & $\begin{array}{l}\text { o "meio ambiente } \\
\text { criado" }\end{array}$ & $\begin{array}{l}\text { diferenciação das } \\
\text { integrações social e } \\
\text { de sistema }\end{array}$ \\
\hline
\end{tabular}

*Estado

Desse quadro, cabe comentar aqueles itens que interessam a este capítulo.

No primeiro tipo, de sociedade tribal, a tradição, entendida também como práticas comunitárias, o parentesco e as sanções grupais constituem os princípios estruturais. Como característica, temos que os meios de integração social e de sistema são coincidentes, “dependendo preponderantemente da interação nos cenários de locais de alta disponibilidade e de presença" (op.cit.: 149). 
Esse tipo de sociedade pode ser identificado, na história do Japão, no período que compreende o período Jômon até o surgimento do governo de Yamato, no século III. Conforme foi explanado, os primeiros indícios de estruturação social do Japão na forma de comunidades podem ser encontrados nos vestígios da chamada cultura Jômon, datada de cerca de dez mil anos atrás. Como havia certa organização para a caça e a coleta de alimentos, com a existência da figura de um líder, supõe-se que havia alguma divisão de trabalho na comunidade. Se havia alguma relação hierárquica, seria de natureza religiosa, mas não é possível identificar alguma estratificação ou gradação de status, que possa ser comprovada através de estudos arqueológicos. A introdução da rizicultura e das técnicas de manipulação de metais do continente foi o fator primordial para o surgimento de aldeias fixas e do início de conflitos entre elas, disputando terras, água e alimentos. Por volta do século I, já havia tribos lideradas por chefes, e a partir do século III, já é possível verificar povos subjugados e tornados escravos, como consequência da dominação decorrente das guerras.

O segundo tipo de sociedade, dividida em classes, pressupõe a presença do Estado e a diferenciação da cidade do campo. Justamente por isso, há a separação entre integrações social e de sistema (ibid.). A tradição e as relações de parentesco continuam preeminentes, pois o Estado não consegue atingir completamente a esfera dos costumes; no entanto, existem leis e códigos formais que possibilitam a punição dos transgressores (op.cit.: 150).

No caso japonês, esse tipo de sociedade se forma a partir do século IV, quando surgiu o Estado de Yamato, como uma confederação de vários reinos menores, governado por um soberano que comandava vários clãs, distribuindo títulos. A consolidação do Estado faz-se refletir no plano internacional, quando o Yamato é reconhecido pelos reinos da península coreana no século IV, e da China, no século V. 
No século VII, após um golpe, o poder é centralizado na dinastia imperial, fazendo surgir na prática um Estado imperial centralizado, que dura até o século XII. Nessa fase, já havia distinção social entre a corte, a nobreza, os senhores de terras e os camponeses. Na elite dominante, a diferenciação ocorria através de títulos. A instalação do xogunato de Kamakura, no final do século XII, inaugura a fase feudal da história japonesa, mas a constituição da sociedade estamental de fato se iniciou com as medidas tomadas por Toyotomi Hideyoshi, no século XVI, e se consolidou no período Edo, entre os séculos XVII e XIX.

Por fim, a sociedade de classes é a própria sociedade do capitalismo moderno, cujo princípio estrutural distintivo, segundo Giddens, é a "separação das instituições estatais e econômicas, ainda que estas se mantenham interligadas" (1989: 150) e o que podemos denominar a "racionalização" e a "burocratização":

“O tremendo poder econômico gerado pela utilização de recursos e alocação para uma tendência genérica no sentido do progresso técnico é acompanhado por uma enorme expansão do "alcance" administrativo do Estado. A fiscalização a codificação de informação pertinente à administração das populações súditas, mais a supervisão direta por funcionários e administradores de todos os tipos torna-se um mecanismo decisivo para favorecer o abandono do sistema baseado na integração social. As práticas tradicionais foram dispersadas (sem desaparecimento por completo, é claro) sob o impacto da penetração de procedimentos administrativos codificados na vida cotidiana. Os locais que fornecem os cenários para a interação em situações de co-presença passam por um importante conjunto de transmutações. A antiga relação cidade-campo é 
substituída pela expansão crescente de um "meio ambiente criado" ou fabricado." (ibid.).

No caso do Japão, a sociedade de classes somente é constituída nas primeiras décadas do século XX. O que poderíamos chamar de revolução industrial japonesa ocorreu após a Restauração Meiji, especificamente na década de 1890 (Sato et al., 2008: 381). A primeira siderurgia foi inaugurada em 1901, mas a instalação de fato da indústria pesada no Japão ocorreu após a Guerra Russo-Japonesa (1904-5). Como afirma Sato et al., o capitalismo foi implantado no Japão em aproximadamente meio século, enquanto que nas principais potências, com as quais o Japão estava competindo, esse processo ocorreu num espaço temporal de dois a três séculos (op.cit.: 386).

Essa questão, da industrialização e do advento do capitalismo de forma tardia no Japão, ainda será retomada no Capítulo 5, na discussão sobre as classes sociais.

No esquema acima, organizado à luz dos princípios estruturais de Giddens, é possível dizer que a hierarquia social está presente tanto na tradição quanto no sistema de parentesco e também no Estado. Mas os princípios estruturais estão num nível de abstração acima dos sistemas sociais (op.cit.: 148).

Para atingir o nosso objetivo, portanto, seria necessário verificar os estudos que tem como foco a hierarquia social no contexto da sociedade de classes, ou melhor, no contexto da classe em si. Antes, porém, estudar-se-á o imperador que, no caso japonês, tem origem na sociedade tribal e atravessando a fase da sociedade dividida em classes, se perpetua na atual sociedade de classes. Eis o tema do próximo capítulo. 


\section{Capítulo 4}

\section{O Imperador e a Hierarquia Social: de deus mitológico à simbologia}

\section{1- Introdução}

O imperador Heisei, ou Kinjô Tennô, atualmente no trono ${ }^{127}$, é considerado o centésimo vigésimo quinto imperador da dinastia ${ }^{128}$ iniciada pelo imperador Jinmu, que segundo Nihonshoki ${ }^{129}$ " "Crônicas do Japão", fonte da mitologia japonesa, teria sido entronado em 660 a.C. Do imperador Jinmu ao imperador Senka, vigésimo oitavo, constitui a fase mitológica, sendo que, se contabilizado a partir do imperador Kinmei, vigésimo nono, entronado em 539, a dinastia dura pelo menos cerca de mil quatrocentos e setenta anos.

Para a geração atual de cidadãos comuns japoneses, até recentemente, o imperador era como "a luz solar ou o ar" (Takase, 2005: 9), uma presença que todos sabem que existe, mas que relembram ocasionalmente, como na aparição televisiva ou em momentos especiais como acenando ao público no cumprimento do ano novo, à distância, da sacada do palácio imperial. Esse sentimento de distanciamento parece ter sido alterado após a tragédia de 11 de março de 2011, quando um grande terremoto seguido de tsunami assolou a região nordeste do Japão. Após o pronunciamento na cadeia nacional de televisão imediatamente após o incidente, o imperador e a imperatriz

\footnotetext{
${ }^{127}$ No Brasil, comumente refere-se ao atual imperador como imperador Akihito, embora essa prática não seja comum entre os japoneses.

128 Incluindo a fase mitológica e histórica. Alguns autores defendem que teria havido uma descontinuidade na sucessão e que a dinastia sofreu rupturas, pois alguns imperadores não deixaram herdeiros e parentes distantes, algumas vezes de comprovação duvidosa, foram entronados. De fato, a questão é controversa, mas não vem ao caso detalhar essa discussão aqui.
} 
cumpriram um itinerário de visita aos locais afetados, começando pelo centro provisório de refugiados em Tóquio, no final de março, seguindo para Chiba e Ibaraki, percorrendo ainda Miyagi, em 27 de abril, e Iwate, no dia 6 de maio. Os meios de comunicação destacaram a emoção das vítimas ao serem confortadas, e a repercussão mostrou o quanto o imperador e a imperatriz significam para o povo, como elemento agregador da nação japonesa (Yasuda, 2011: iii).

Para Otsu, o fato de o Estado moderno japonês ter sido organizado em torno da figura do imperador trouxe implicações que impediram que o papel do imperador fosse analisado com objetividade, principalmente na disciplina de História, no período anterior à Segunda Guerra Mundial (2010: 14). Após o término da Guerra, com a derrota do Japão e o colapso do regime militar, o imperador passou a significar o emblema do Japão que deveria ser descartado e esquecido, para os críticos dessa fase.

Autoritarismo e submissão, veneração e rejeição, distanciamento e proximidade, são alguns elementos, muitas vezes contraditórios, que se mesclam para formar o complexo mosaico da imagem e do sentimento do povo japonês em relação ao seu imperador.

\section{2- A origem mítica e a tradição religiosa}

O título de tennô - imperador - teria se iniciado no trono de Tenmu $(?-686)$, que esteve no poder de 673 a $686^{130}$. Um imperador carismático, seu prestígio junto aos

\footnotetext{
${ }^{129}$ Concluído em 720, trata da história do Japão, da era mitológica até o período da imperatriz Jitô (6907).

130 A prova arqueológica mais antiga do imperador foi encontrada em 1998, na ruína de Asukaike, em Asuka, na província de Nara, na tabuleta onde se verifica a palavra tennô, imperador, presumidamente do final do século VII (Kumagai, 2001: 9).
} 
súditos teria se iniciado ainda na condição de príncipe Oama, na luta contra o príncipe Otomo, na disputa pelo trono após o falecimento do imperador Tenji, em 671. Partindo de uma situação adversa, aliando tomadas de decisões e alianças militares acertadas, em poucos dias suplantou o concorrente, e foi considerado imbuído de divindade pela façanha $^{131}$ (Kumagai, 2001: 334).

O imperador Tenmu era devoto da deusa Amaterasu, que representava o sol e o celeste $^{132}$. Cultuada no templo Ise ${ }^{133}$, Amaterasu foi rapidamente oficializada como a deusa fundadora da linhagem imperial, sendo o imperador considerado seu descendente.

Como afirma Yoshida (1997), é nesse período histórico que é cunhada a palavra nippon (Japão), sendo que o primeiro ideograma que forma essa palavra significa sol, no caso representando a deusa Amaterasu, e o conjunto significa "país governado pelo descendente da deusa do sol"134. Dessa forma, tennô significa descendente da deusa Amaterasu e expressa a confluência entre a mitologia e a figura carismática do Tenmu, para dar um caráter místico-religioso ao imperador (Kumagai, op. cit.: 340 e ss). Não por acaso, é sob o trono de Tenmu que ocorre a iniciativa de organizar os estudos que resultam no Kojiki ("Registro de Fatos Antigos")" 135 e no Nihon Shoki ("Crônicas do Japão") ${ }^{136}$. Ademais, os rituais de culto ao imperador, destacando a sua divindade, foram sistematizados nesse período, destacando-se a criação de Daijôsai, uma grande cerimônia de agradecimento aos deuses pela colheita, realizada uma única vez, após a entronização.

\footnotetext{
${ }^{131}$ Trata-se do episódio que ficou registrado como o Conflito de Jinshin (672).

${ }^{132}$ Ainda no início da guerra contra o príncipe Otomo, teria feito uma prece à deusa pedindo ajuda, na beira do rio Toho (atual rio Asake, na província de Mie). Vitorioso, intensificou rituais de veneração da deusa, como que pagando uma promessa pelo pedido atendido (Kumagai, 2001: 340).

133 Situa-se na província de Mie, região central do Japão.

${ }^{134} \mathrm{O}$ segundo ideograma que forma a palavra nippon significa literalmente "base", e deve ser interpretado como "imediatamente abaixo do sol", ou seja, "sob o auspício da deusa solar". A tese corrente de que significa "país do sol nascente" deve ser descartada, pois se baseia no ponto de vista da China, portanto, um olhar forasteiro (Kumagai, op. cit.: 342).

${ }^{135}$ Considerado o registro histórico mais antigo do Japão, concluído em 712.
} 
As principais iniciativas de deificação do imperador tomadas no período em que Tenmu esteve no poder são aprofundadas e consolidadas sob a imperatriz Jitô, sua sucessora (690-697), e do imperador Monmu (697-707). Quando Jitô sobe ao trono, consta que os súditos bateram "palmas" para a imperatriz, ação esta conhecida atualmente como parte do rito xintoísta, de louvor a deuses, demonstrando, assim, que pela primeira vez, o ritual religioso era praticado na ascensão de um imperador (imperatriz, no caso). Na entronização de Monmu, em 697, ele é anunciado como akitsumikami, "deus em pessoa", como manifestação divina em pessoa, prática que, desde então, torna-se regra (Kumagai, op.cit.: 345). Essa tradição ritualística continua até 781, quando Kanmu ocupa o trono, e se inicia uma secularização, no sentido de eliminar os componentes mitológicos do ritual, aproximando-o do modelo chinês (Osumi, 2001: 70), mas, ao longo da história, a divindade do imperador sempre esteve pressuposta e latente nas cerimônias de entronização e nas celebrações religiosas (Maruyama, 2001).

Atualmente, no $\operatorname{artigo} 7^{\circ}$ da Constituição do Japão, que versa sobre as atribuições do imperador, consta no inciso 10, "realizar cultos" (Takase, 2005: 18). Anualmente, são realizados vinte e sete tipos de cultos de regularidades diferentes, como o culto diário matinal ${ }^{137}$, mensal (chamado shunsai, realizado nos dias $1^{\circ}, 11$ e 21 ) e anual (por exemplo, shihôhai, realizado no dia $1^{\circ}$ de janeiro; kannamesai, celebrado no dia 17 de outubro; niinamesai, no dia 23 de novembro) (Ogura e Yamaguchi, 2011: 364-5). De um modo geral, são rituais que louvam os deuses, pedindo proteção e fertilidade ao Japão. Alguns rituais têm origem no agradecimento aos deuses pela boa colheita, como é o caso do niinamesai, também chamado shinjôsai, em que se come o

\footnotetext{
${ }^{136}$ Cf. nota 129.

${ }^{137}$ Denominado godaihai, pode ser executado pelo sacerdote, em substituição ao imperador.
} 
arroz recém colhido da nova safra, ainda hoje celebrado inclusive com a presença do primeiro-ministro e membros do gabinete.

\section{3- Era Antiga: o Estado imperial centralizado}

Como foi asseverado no Capítulo 3, do ponto de vista histórico, o imperador ${ }^{138}$ foi convertido, aos poucos, de chefe tribal local para chefe da confederação de comunidades, e daí para o supremo mandatário da nação, adquirindo, nesse percurso, autoridade política e religiosa. Nesse sentido, conforme visto no capítulo anterior, a Reforma Taika (645) foi um dos marcos importantes do Japão Antigo, por representar a organização do Estado sob o monopólio do poder político nas mãos do imperador.

$\mathrm{Na}$ fase das regências, dos meados do século IX a final do século XI, o poder do imperador é relativizado dependendo do mandatário no trono e das circunstâncias políticas, mas jamais ele deixou de dar a última palavra no plano políticoadministrativo, nem perdeu a importância religiosa.

\section{4- Período feudal: a legitimidade dos governos}

Durante o chamado período feudal, exceto pequeno interregno no início do século XIV, o imperador teve que submergir diante da tomada de poder pelos guerreiros. Isso se inicia com o estabelecimento do xogunato de Kamakura ${ }^{139}$, em 1192,

\footnotetext{
${ }^{138}$ O emprego do termo "imperador" aqui é por conveniência, pois este só passou a ter os atributos e as prerrogativas que atualmente são considerados próprios do imperador a partir do século VII.

${ }^{139}$ Cf. item 3.9 do Capítulo 3.
} 
quando o estamento guerreiro chega ao poder. Nessa fase, a corte imperial consegue manter influência sobre os nobres, residentes em Quioto, e senhores de terras da região oeste do arquipélago, distantes, portanto, de Kamakura, sede do xogunato.

No século XIV, após o Período da Corte Norte e $\mathrm{Sul}^{140}$, em que o imperador Godaigo manifestou resistência ao domínio dos guerreiros, a fase do xogunato de Muromachi foi, talvez, a mais crítica da história da corte imperial. Houve inclusive uma tentativa de usurpação do status de imperador por parte do xogum Yoshimitsu, abortada com sua morte, em 1394.

Do final do século XV ao final do século XVI, a corte imperial sobrevive à fase conturbada de intensas guerras entre os daimiôs, não hesitando em se aproximar dos que servissem a seus interesses (Fujii, 2011). Destacando apenas os personagens principais, a relação com Oda Nobunaga foi de conflito e com Toyotomi Hideyoshi, uma relação de convivência, sem a tentativa de anulação mútua.

Durante o xogunato de Tokugawa, o poder político dos imperadores foi reduzido, chegando a ser nulo em alguns momentos. Não obstante, os sucessivos governantes guerreiros mantiveram a formalidade de ser nomeado xogum generalíssimo combatente dos bárbaros - pelo imperador e a sua relação e ascendência sobre os vassalos só se justificava perante essa condição. Em suma, o imperador não era protagonista da política e do governo, mas era uma peça-chave indispensável e necessária para que todo o sistema de dominação funcionasse (Kochi; Nitta, 2011: 339). No plano espiritual e religioso, o imperador era a autoridade máxima para celebrar rituais de pacificação da nação, e nesse sentido tinha ascendência sobre todos os santuários e templos. Ademais, no plano simbólico, o imperador sempre manteve o

${ }^{140}$ Ibid. 
status e a autoridade de soberano da nação, e também trazia consigo o glamour da corte, admirado pelos letrados e nobres (Fujita, 2011: 19-20).

\section{5- O imperador e a modernização do Japão}

Como anteriormente exposto, a Restauração Meiji foi orquestrada por senhores feudais do oeste do arquipélago, que derrubaram o xogunato e se apoderaram do poder em nome do imperador. Novamente, era o imperador que legitimava o movimento restaurar o trono - e em torno dele é erguido o Estado centralizado com tendência totalitária, que se baseia no culto ao imperador considerado pai, numa analogia à família, sendo os súditos seus filhos, sendo toda a nação uma grande família. Surge assim o Grande Império Japonês, cujo artigo primeiro da Constituição determina a inviolabilidade da condição divina do imperador ${ }^{141}$. As medidas centralizadoras, assim como de exceção, eram o preço a pagar pela modernização acelerada que o Japão precisava promover em poucas décadas para se igualar às potências do Ocidente, países estes que levaram pelo menos um século para atingir o mesmo patamar desejado pelos japoneses (Yasuda, 2011).

Já no final do século XIX e início do século XX, os gargalos para o desenvolvimento - território reduzido, poucos recursos naturais, pobreza do campo - e a conjuntura internacional levam o Japão para a corrida armamentista e expansão territorial. A vitória nas guerras contra a China (1894-5) e contra a Rússia (1904-5) contribuiu para acelerar esse processo, que vai culminar na Guerra do Pacífico (1941-5). 
4.6- O caráter simbólico e a polêmica sobre a responsabilidade na guerra

Após a derrota do Japão na Guerra do Pacífico, a corte imperial japonesa foi preservada pelos americanos, extraindo-se todo o poder executivo, legislativo e judiciário que acumulava segundo a constituição Meiji, tornando-se apenas um símbolo da nação ${ }^{142}$.

A derrota do Japão na guerra acarretou, além das vítimas e danos materiais, o estabelecimento de alguns princípios que parecem invioláveis. $\mathrm{O}$ primeiro seria $\mathrm{o}$ pacifismo a qualquer custo, e o segundo seria a negação de tudo que remete ao nacionalismo. Por exemplo, a bandeira do Japão e seu hino, cuja letra louva o imperador, eram considerados resquícios dessa fase e foram contestados por segmentos importantes do Japão. O governo japonês teve que aprovar no parlamento uma lei, em 1999, oficializando-os ${ }^{143}$ e tornando obrigatório o hasteamento da bandeira e a entoação do hino. Nessa questão, a responsabilidade do imperador sobre os acontecimentos da Segunda Guerra também é polêmica, inclusive na academia. Obviamente, há setores da direita nacionalista, minoritários, que defendem a causa imperialista, às vezes com o uso da violência ${ }^{144}$.

Para muitos ativistas, principalmente dos países que foram ocupados pelo Japão na Segunda Guerra - China e Coreia -, em nome do imperador, o Japão invadiu fronteiras, dominou povos e provocou massacres. Para os defensores, em nome do imperador,o Japão pôs fim à guerra que vitimou milhares de pessoas.

\footnotetext{
${ }^{141} \mathrm{O}$ culto à imagem do imperador era corporificado no goshin'ei, "imagem sagrada", fotografia do casal imperial, que era ostentado nas escolas e repartições públicas, a partir da década de 1870.

${ }_{142}$ Não obstante, de acordo com a Constituição do Japão, formalmente, é o imperador que nomeia o primeiro-ministro, o presidente do Supremo Tribunal e o presidente do Congresso.

${ }_{143}^{143}$ Até então, eram fundamentados no direito consuetudinário.

${ }^{144} \mathrm{O}$ caso mais famoso é o de um atentado protagonizado por membro de um grupo radical de direita contra o prefeito de Nagasaki, em 1990, que afirmou considerar o imperador Showa, que havia acabado
} 
A posição em relação ao imperador é um tema complexo cujo debate não pode ser aqui resumido, mas acarreta posturas muitas vezes de indiferença justamente pelo seu teor polêmico, sendo considerado tabu por muitos.

4.7- O Imperador e a hierarquia: análise do resultado da pesquisa de campo

A pergunta "Se se considerar hipoteticamente escalonar todos os japoneses do Japão hierarquicamente, quem deve ocupar a posição superior dentre todos?”, aberta (cf. 8.25), teve respostas que classificadas categoricamente, podem ser assim organizadas:

Tabela 1: Resultado das respostas dos informantes sobre quem eles consideram que ocupa a posição superior dentre todos no Japão

\begin{tabular}{cccccccc}
\hline & $\begin{array}{c}\text { Sem } \\
\text { resposta }\end{array}$ & Imperador & Outros & $\begin{array}{c}\text { Primeiro- } \\
\text { ministro }\end{array}$ & $\begin{array}{c}\text { Não } \\
\text { sabe }\end{array}$ & Ninguém & total \\
\hline No. & 24 & 22 & 13 & 11 & 6 & 5 & 81 \\
$\%$ & 29,6 & 27,2 & 16,0 & 13,6 & 7,4 & 6,2 & 100 \\
\hline
\end{tabular}

Como é possível interpretar esses números?

À luz da discussão feita até aqui, é até surpreendente que 27,2\% dos informantes tenham respondido o "imperador", numa pergunta não estimulada ${ }^{145}$. Seria o reflexo dos acontecimentos recentes, em que o papel do imperador foi reconsiderado? Como motivo

de falecer, como o responsável pelo envolvimento e derrota do Japão na guerra. Um estudo acadêmico sobre esse incidente encontra-se em Field (1991).

$145 \mathrm{Na}$ "Pesquisa sobre o Pensamento dos Japoneses" [Nihonjin no Ishikichôsa], realizado quinquenalmente pela estatal NHK desde 1973, o percentual daqueles que responderam "serem indiferentes" em relação ao imperador sempre marcou altas taxas, chegando ao pico de 47\% em 1988. $\mathrm{Na}$ era Heisei (1989-), tem oscilado entre 34 e 44\% (1993-34\%; 1998-44\%; 2003-36\%; 2008-39\%). 0 percentual daqueles que responderam "respeitarem o imperador" tem apresentado queda consecutiva até 1998 (1973-33\%; 1978-30\%; 1983-29\%; 1988-28\%; 1993-21\%; 1998-19\%), mostrando uma curva ascendente a partir de 2003 (2003-20\%; 2008-25\%) (NHK Hoso Bunka Kenkyujo, 2010: 119). Este último número sugere uma alteração na tendência de até então, que poderá ser confirmada pelos dados de 2013. 
para ter dado essa resposta, a maioria evocou o "símbolo do país", talvez a mais politicamente correta possível, seguida por respostas que mencionam autoridade, privilégio e tradição:

Tabela 2: Justificativa dos que responderam que o imperador ocuparia a posição superior máxima

\begin{tabular}{lcc}
\hline \multicolumn{1}{c}{ resposta } & No. & \% \\
\hline "porque é o símbolo do país" & 10 & 45,5 \\
"tem autoridade ou privilégio" & 5 & 22,8 \\
"porque é tradição, ou faz parte da & 4 & 18,2 \\
história" & & \\
"porque é o chefe de Estado" & 2 & 9,0 \\
sem resposta & 1 & 4,5 \\
Total & 22 & 100 \\
\hline
\end{tabular}

De qualquer maneira, foi possível constatar que o imperador é um tema delicado para a maioria dos entrevistados, que perguntados se discutiam com os familiares ou amigos sobre o imperador, responderam que não, como a informante que afirmou ser o assunto uma "espécie de tabu", e que temia que fosse tachada de "ser da direita", mesmo que, pessoalmente, considerasse o imperador superior a todos ${ }^{146}$.

Por outro lado, não é possível ignorar as respostas dos que responderam o "primeiro-ministro":

\footnotetext{
${ }^{146}$ Informante feminino, 50 anos, serviço social, entrevistada em 16 de agosto de 2011, em Yamagata.
} 
Tabela 3: Justificativa dos que responderam que o primeiro-ministro ocuparia a posição superior máxima

\begin{tabular}{lcc}
\hline \multicolumn{1}{c}{ resposta } & No. & $\%$ \\
\hline “porque é o líder do país"; "porque é o & 4 & 36,3 \\
número 1 da hierarquia" & & \\
“porque define as políticas, manda" & 3 & 27,3 \\
"porque é o representante do povo" & 2 & 18,2 \\
“porque não vejo alternativa" & 2 & 18,2 \\
Total & 11 & 100 \\
\hline
\end{tabular}

Embora em número reduzido, pelo fato de a amostragem ser reduzida, esses informantes ignoram a superioridade ou a ascendência do imperador. Como afirmou uma entrevistada, de posição mais radical, e por isso certamente minoritária: "para que a voz do povo seja ouvida", deve ser introduzido o presidencialismo no Japão e, para tanto, "o imperador deve ser extinto"147.

Por outro lado, o que foi possível constatar, na pesquisa de campo, é a descrença em relação aos políticos, principalmente pelo fato de no Japão nenhum gabinete ter conseguido se manter por mais de um ano, em média ${ }^{148}$, como afirmou uma informante que, "nessas condições, ficamos sem alternativa"149.

Dessa forma, por não considerar, de fato, o imperador ser o superior de todas as posições sociais, ou por não acreditar nos políticos, e por consequência no primeiroministro, é compreensível a manifestação significativa de $43 \%$, percentagem esta obtida da soma daqueles que optaram por não responder $(29,6 \%)$, mais os que claramente responderam "não tem" $(6,2 \%)$ e "não sabe" $(7,4 \%)$, e talvez possa justificar também as respostas dos que responderam de formas diferentes, cujo conteúdo não vem ao caso

\footnotetext{
${ }^{147}$ Informante feminino, 59 anos, chefe de enfermeiras. Entrevistada em 29 de julho de 2011, em Tóquio. ${ }^{148}$ Nos últimos cinco anos, foram nomeados seis primeiros-ministros, sendo que o atual, Noda Yoshihiko, ocupa o cargo desde setembro de 2011.

${ }^{149}$ Informante feminino, 45 anos, setor de serviços, em 17 de novembro de 2011, em Saitama.
} 
discutir (cf. 8.26.2), mas somam uma parcela considerável (16\%), superando, inclusive, aqueles que optaram pelo primeiro-ministro. É perfeitamente provável que essas posições incluam aquelas que preferiram se omitir, dada a delicadeza da questão.

\section{8- Considerações finais do capítulo}

No presente capítulo, mais do que discutir a relevância ou não da figura do imperador na evolução e nos desdobramentos da Segunda Guerra Mundial, o nosso propósito foi verificar a continuidade da autoridade do imperador ao longo da história, a legitimidade que o imperador conferia ao governo da época, e o respeito e, em muitos contextos, a veneração que ele acarretava e acarreta no sentimento da população. É necessário manter a objetividade e o senso de equilíbrio para analisar a figura emblemática e ao mesmo tempo complexa do imperador, ao longo da história do Japão.

A verdade é que do imperador Showa (Hirohito) ao atual imperador Heisei (Akihito), houve uma mudança profunda no comportamento e na forma como isso é projetado junto ao povo japonês ${ }^{150}$. O atual mandatário se desloca mais ao exterior ${ }^{151}$, se apresenta mais cosmopolita, manifesta opiniões pessoais, é mais midiático como ator global (Fujitani, 2003), embora isso não implique, necessariamente, maior proximidade e acessibilidade pela população ${ }^{152}$.

\footnotetext{
150 Por exemplo, na "Pesquisa sobre o Pensamento dos Japoneses" [Nihonjin no Ishikichôsa], aqueles que responderam que "têm simpatia pelo imperador" jamais passaram de $22 \%$ na era Showa (197320\%; 1978-22\%; 1983-21\%; 1988-22\%), mas na era Heisei, esses números passaram para a casa de $30 \mathrm{e}$ 40\% (1993-43\%; 1998-35\%; 2003-41\%; 2008-34\%). Cf. NHK Hoso Bunka Kenkyujo, 2010: 119.

${ }^{151} \mathrm{O}$ imperador Showa esteve apenas duas vezes no exterior, durante os 63 anos em que esteve no trono, enquanto que o imperador Heisei viajou por oito vezes já na primeira década (Fujitani, 2003: 245).

${ }^{152}$ Em 1998, na solenidade dos Noventa Anos da Imigração Japonesa no Brasil, realizada em Belo Horizonte, tivemos a oportunidade de presenciar o imperador a uma distância de sete a oito metros. Um japonês nativo que estava presente no evento comentou que, no Japão, jamais teria uma oportunidade como aquela, de estar tão próximo ao imperador.
} 
Percebe-se que, entre os japoneses que refletem a respeito, há um sentimento ambíguo em relação ao imperador. Quando se olha para o passado, surge um sentimento de repulsa, que logo se converte na vontade de esquecer, de fechar os olhos e achar que nada daquilo aconteceu, e quando se olha para o presente, novamente o imperador surge como alicerce da superação para muitos, da longa reconstrução material e sentimental que precisarão enfrentar. E isso, de certa forma, vem à tona ao tentar vincular a hierarquia social no país ao imperador, seja na manifestação, na omissão, ou dubiedade de seus posicionamentos. 


\section{Capítulo 5}

\section{Classe Social, Estratificação e Hierarquia}

\section{1- Introdução}

Ruth Benedict destacou a classe social como um fator preponderante no estabelecimento da hierarquia, conforme visto no capítulo 2. Nakane Chie, por seu turno, considerou a noção de classe social irrelevante e até desnecessária para se compreender as relações sociais entre os japoneses (1967: $\left.96^{153}\right)$.

Entre esses pólos opostos de postura em relação às classes sociais, o presente capítulo pretende discutir a atualidade e a pertinência dessa categoria analítica quando aplicada na sociedade japonesa, tentando estabelecer alguma referência para a compreensão da hierarquia social dos nipônicos.

Um ponto importante a considerar, inicialmente, é que poucos estudos feitos no Japão levam o título de "classe social", sendo que a maioria prefere empregar o termo "estrato social". Então, para uma maior adequação da discussão, é necessário, inicialmente, fazer uma revisão desses conceitos, partindo dos autores clássicos da Sociologia.

Historicamente, o surgimento do conceito de classe social precede o de estrato social. Dessa forma, pela ordem, será feita uma discussão sucinta sobre a classe social seguida da de estratificação social, procurando caracterizar seu uso também no contexto

\footnotetext{
${ }^{153}$ A autora assim afirma a respeito: "Algo como a classe social [shakai kaisô], que pode ser observada no Ocidente, poderia também ser objetivamente observada no Japão estabelecendo-se, por ora, algo semelhante, seguindo o modelo sociológico ocidental, mas aponta-se para o fato de que isso dificilmente possui utilidade na sociedade de fato e que não reflete a real estrutura social.” (1976: 96).
} 
da sociedade japonesa. Por fim, verificar-se-á a atualidade das relações de classe ou de estratos, ou ainda de status, na aplicação à hierarquia social japonesa.

\section{2- Classe social}

Teria sido Saint-Simon um dos primeiros autores a desenvolver a teoria das classes sociais, no bojo do estudo que visava compreender o desenvolvimento da Europa, da era clássica à contemporânea, marcada pela industrialização e o advento do capitalismo (Giddens, 1975: 26) ${ }^{154}$. Saint-Simon caracterizou a idade contemporânea como uma época de conflitos de classes por ser de transição, do feudalismo à sociedade industrial, cujos personagens seriam a classe industrialista, formada por aqueles que “trabalham para produzir ou para colocar à disposição dos vários membros da sociedade um ou muitos meios de satisfazer as suas necessidades ou as suas predileções físicas..." ${ }^{155}$, e uma outra classe formada pelos demais elementos remanescentes do feudalismo (Giddens, ibid.).

A partir de então, classe social tornou-se um dos principais conceitos da análise sociológica, sendo sua concepção modificada, ampliada e aperfeiçoada, com posicionamentos pró e contra, por diferentes correntes do pensamento sociológico.

\footnotetext{
${ }^{154} \mathrm{Na}$ introdução de Pré-capitalismo e Capitalismo, assim afirma Hirano: “(...) o capitalismo e as classes sociais foram constituídas no decorrer dos séculos XVIII e XIX; a própria palavra capitalismo somente a partir de 1860, segundo Hobsbawm, começa a ter um uso mais difundido. E a mão-de-obra livre assalariada, necessária porque essencial à produção capitalista, no entender de Marx somente se constituiu como categoria econômica plenamente na Inglaterra do ponto de vista formal em fins do século XVIII. (...) O mesmo ocorre com as classes sociais, que são categorias históricas, elaboradas a partir dos séculos XVIII e XIX pelos economistas franceses e ingleses para a análise dos fenômenos econômicos resultantes de um processo de desenvolvimento capitalista que principiara nos meados do século XVIII e se intensificara cumulativamente no século XIX. Capitalismo e classes sociais são categorias históricas que pertencem à história do capital industrial e foram elaboradas conceitualmente para explicá-lo." (1988: 8-9). Grifo do autor.

${ }^{155}$ Saint-Simon. La Physiologie Sociale. Paris: Ed. Gurvitch, 1965, p. 141, apud Giddens, 1975: 26.
} 
Examinando as contribuições dos teóricos que desenvolveram esse conceito ao longo de quase duzentos anos, o seu critério de definição pode expressar divisões econômicas e de interesses, ou distinções de natureza cultural (Scott, 1996). Essa diversidade se origina, no entanto, de dois autores clássicos: Marx e Weber.

5.2.1- A visão clássica de classe social: as tradições marxista e weberiana

\subsubsection{1- Karl Marx e a tradição marxista}

Desde que apresentou, em co-autoria com Friedrich Engels, o famoso Manifesto do Partido Comunista que se inicia com a emblemática afirmação "a história de toda sociedade até hoje é a história de lutas de classes" (Marx e Engels, 1998: 66), Karl Marx foi associado ao conceito de classes sociais. É importante salientar que, ao longo de sua vasta produção, Marx jamais definiu formalmente a classe social ${ }^{156}$, portanto, as consideradas concepções marxistas de classe social são, essencialmente, inferências teóricas feitas a partir das afirmações encontradas em seus escritos ${ }^{157}$.

Marx incorporou vários aspectos da concepção de classe de Saint-Simon (Giddens, 1975: 31), mas deu maior ênfase à luta de classes, intrínseca à sociedade industrial capitalista, como principal elemento de superação do capitalismo e transição para o socialismo, um estágio sem classes da sociedade. Então, no marxismo, a luta política é inerente à classe social, ou formulado de outra forma, a classe está desde

\footnotetext{
156 Para Giddens, esse fato torna a questão "complicada", uma vez que Marx faz uso variado e "descuidado" do termo "classe", mas considera que, na essência, o que importa é "até onde esse relaxamento terminológico esconde ambiguidades ou confusões conceituais" (1975: 31).

${ }^{157}$ Como é amplamente conhecido, o volume III de $O$ Capital é interrompido exatamente no ponto em que parecia que Marx finalmente iria elaborar uma conceituação a respeito.
} 
sempre imbricada com a luta ou os conflitos entre as classes e, dessa forma, discutir a teoria das classes de Marx requer, inevitavelmente, discutir o conflito de classes. Esse trecho do Manifesto do Partido Comunista resume esse pensamento:

“A nossa época, a época da burguesia, caracteriza-se, entretanto, por ter simplificado os antagonismos de classe. A sociedade inteira vai-se dividindo cada vez mais em dois grandes campos inimigos, em duas grandes classes diretamente opostas entre si: burguesia e proletariado" (1998: 67).

Partindo dessa afirmação, verifica-se que o modelo de classe de Marx é essencialmente dicotômico, tendo, de um lado, aquela formada por detentores, minoritários, da propriedade e do controle dos meios de produção, que extraem da outra classe, formada por uma maioria desprovida desses meios, o produto excedente para sua existência e, com isso, exerce uma dominação e exploração econômica ${ }^{158}$.

Cabe destacar que Marx denominava "pequenas camadas médias" os pequenos industriais, os pequenos comerciantes e os que viviam de pequenas rendas, os artesãos e os camponeses, como uma parcela fora das classes da burguesia e do proletariado. No entanto, seu destino era "cair" no proletariado, derrotados na concorrência com grandes capitalistas ou desvalorizados pelos novos métodos de produção (op. cit., 73).

Dessa forma, conforme Marx, a classe social pode ser classificada em:

a) burguesia: industriais e proprietários de fábricas;

\footnotetext{
158 A rigor, Marx classificou uma classe de proprietários de terras, mas considerava ser "tendência constante e lei do desenvolvimento do modo capitalista de produção" converter "os meios de produção em capital", e essa tendência vir a corresponder ao "fato de a propriedade fundiária, como entidade autônoma, se dissociar do capital e do trabalho, isto é, a conversão de toda propriedade fundiária à forma adequada ao modo capitalista de produção" (1968: 1013).
} 
b) pequena burguesia: pequenos industriais, comerciantes, artesãos e camponeses;

c) proletariado: operários assalariados.

Obviamente, essa síntese não pretende esgotar todas as contribuições de Marx no que diz respeito à teoria das classes sociais. Por exemplo, em As Lutas de Classes na França 1848 a 1850, Marx chega a classificar sete classes: aristocracia financeira, burguesia industrial, burguesia comercial, classe operária, pequena burguesia, classe camponesa, classe proletária e subproletariado [Lumpen-proletariat] (Marx, 1956: 31 ess). Segundo Stavenhagen, a concepção de classe social de Marx pode ser classificada em três aspectos (1966: 129-130): o filosófico, encontrado nas obras de juventude de Marx, até o Manifesto Comunista; o econômico, em $O$ Capital; e o histórico, encontrado nas obras As Lutas de Classes na França, O Dezoito Brumário de Luís Bonaparte e A Guerra Civil na França. O objetivo aqui é fazer dessa síntese um intróito para a discussão dos trabalhos dos autores que se autodenominam marxistas, que, por sua vez, inspiraram alguns pesquisadores japoneses, embora esses não tenham feito, a rigor, uma análise de classe fiel à teoria de Marx, como será examinado adiante.

Os autores que se autodenominam marxistas ampliaram o modelo essencialmente dicotômico de Marx, acrescentando uma classe intermediária, entre a classe capitalista e a proletária. Segundo Dahrendorf, teriam sido Lederer e Marschak os primeiros a caracterizarem a "nova classe média", composta por burocratas e empregados de escritório (1982: 56). Nessa linha de análise, podem ser citados Nicos Poulantzas, que sugeriu a "nova pequena burguesia" (1975; 1982), e Erik Olin Wright (1981), embora, posteriormente, na revisão que faz na sua teoria, incorpore fatores 
como posição dentro da organização e posse de qualificações (1985), estranhos ao marxismo.

\subsubsection{2- Max Weber e tradição weberiana}

A teoria de classe social em Max Weber se configura como um importante contraponto ao modelo marxista. Na célebre definição de classe social tal qual um fenômeno de ordem social, Weber a define como "forma pela qual os bens e serviços econômicos são distribuídos e usados" na comunidade (1982: 212). Nessa ótica, a classe constitui um dos fenômenos de distribuição do poder dentro de uma comunidade, determinado pela situação de mercado, ou seja, o fator econômico, ao lado de estamento, que se refere à distribuição de honrarias, e de partido, de distribuição do poder político.

Segundo Weber, uma classe se constitui quando certo número de pessoas apresenta em comum "oportunidades de vida" que são representadas exclusivamente pelos interesses econômicos da posse de bens e oportunidades de renda, e nas condições de mercado de produtos ou mercado de trabalho (ibid.).

Numa exposição sistemática feita no capítulo "Estamentos e Classes", em Economia e Sociedade, Weber faz a distinção entre a "situação de classe" e a classe. A primeira é definida como "a oportunidade típica" de "abastecimento de bens", "posição de vida externa" e "destino pessoal" que resulta da "extensão e natureza do poder de disposição (ou falta deste) sobre bens ou qualificação de serviço e da natureza de sua aplicabilidade para a obtenção de rendas ou outras receitas”, enquanto que a classe é definida como "todo grupo de pessoas que se encontra em igual situação de classe" 
(2000: 199). Nesse contexto, Weber apresenta uma categorização de classes que pode assim ser resumida (op.cit.: 199-201):

a) classe proprietária positivamente privilegiada: rentistas (de terras, instalações, valores, etc.) e credores em geral;

b) classe proprietária negativamente privilegiada: "classes médias" em geral, dependentes, endividados, etc.;

c) classe aquisitiva positivamente privilegiada: empresários; banqueiros; em algumas circunstâncias, profissionais liberais com capacidade ou formação especial (advogados, médicos, artistas) e trabalhadores com qualidades próprias ou adquiridas;

d) classe aquisitiva negativamente privilegiada: trabalhadores em geral, qualificados ou não-qualificados; camponeses e artesãos autônomos; funcionários públicos e privados.

\subsection{2- Visão conciliadora de classe social: alguns destaques}

O legado de Weber, de priorizar o fator do mercado na determinação das classes, consolidou uma linha teórica avessa à ênfase na luta de classes, típica da linha marxista, sem, no entanto, desmerecer seus méritos.

Por exemplo, concordando com a essência da concepção de classe de Marx, Anthony Giddens realiza o que denomina "reconceptualização frutífera" desta, incorporando o conceito de "possibilidade de mercado", ou seja, "todas as formas de atributos relevantes que os indivíduos podem trazer para o momento da troca" (1975: 123), conceito este inspirado em Weber. Segundo Giddens, há três tipos de possibilidade de mercado, a saber, a posse de propriedade dos meios de produção, a 
posse de qualificações técnicas ou educacionais e a posse da força de trabalho manual. São essas três possibilidades de mercado que fundamentam a estruturação de classes na sociedade capitalista em, respectivamente, classe "alta", "média" e "baixa" (“trabalhadora") (op. cit.: 128 e 129).

Pierre Bourdieu admite a natureza conflitante das classes na vida social, mas afirma que a classe social "não é definida por uma propriedade (mesmo que tratasse da mais determinante, tal como o volume e a estrutura do capital), nem por uma soma de propriedades (sexo, idade, origem social ou étnica - por exemplo, parcela de brancos e de negros, de indígenas e de imigrantes, etc. -, remunerações, nível de instruções, etc.), tampouco por uma cadeia de propriedades, todas elas ordenadas a partir de uma propriedade fundamental - a posição nas relações de produção -, em uma relação de causa a efeito, de condicionante e condicionado, mas pela estrutura das relações entre todas as propriedades pertinentes que confere seu valor próprio a cada uma delas e aos efeitos que ela exerce sobre as práticas" (2008: 101), dentro do quadro teórico que destaca a herança social e a trajetória do indivíduo, condensadas, nos conceitos de habitus e de capital cultural. 
5.2. 3- A teoria de classes sociais na Sociologia japonesa

\subsubsection{1- Histórico}

A teoria das classes sociais teria sido introduzida no Japão na esteira da transmissão da Sociologia do Ocidente ${ }^{159}$, sendo o marco importante a inauguração do curso de Sociologia na Faculdade de Letras da Universidade Imperial de Tóquio, em 1919 (Kawai, 2003). Na década seguinte, surgiram as primeiras publicações sobre o marxismo, notadamente da autoria de Takata Yasuma (1883-1972) (Ogasawara, 2000: 72-3).

Entretanto, dentro da conjuntura de ascensão do militarismo e da extrema direita na cena política nacional, os trabalhos de inspiração marxista não tiveram espaço para se desenvolver: a repressão não possibilitava que se pesquisassem temas “ideologicamente à esquerda" (Ogasawara, 2000: 279), e a teoria marxista, identificada com o comunismo, era um deles. As pesquisas de cunho marxista viriam a se tornar viáveis somente após o término da Segunda Guerra Mundial, com a liberalização da forma de pensamento e o advento da estabilização social em todos os setores da sociedade $^{160}$.

Não obstante, mesmo no pós-guerra, o materialismo histórico de Marx teve uma aceitação relativamente curta na Sociologia japonesa, sendo seu auge a primeira metade

\footnotetext{
159 Os primeiros conhecimentos de Sociologia teriam sido transmitidos por Ernest F. Fenollosa (18531908), durante a permanência entre 1878 e 1886 na Faculdade de Letras da Universidade de Tóquio, na condição de "professor estrangeiro contratado" (Ogasawara, 2000: 8 e ss).

160 Convém assinalar que na década de 1930 já havia estudos sobre a estratificação social de orientação funcionalista, portanto não-marxista, tendo como base a ocupação como categoria de classificação. Por exemplo, em 1938, foi publicado Nihonshakai no Dansôteki Kôzô (Estrutura de Estratificação da Sociedade Japonesa), que destaca a ocupação, ao lado da escolaridade, renda e patrimônio, como variável que estabelece a estratificação social (Nihon Shakaigakkai Chôsa Iinkai, 2002:23). Nota-se que se
} 
da década de 1950, entrando em declínio gradativo a partir de 1955. Como causa desse declínio, comumente é apontado o entendimento na academia de que o marxismo não servia para explicar a sociedade japonesa a não ser que passasse por uma grande revisão, assim como a dificuldade de explicar os traços culturais tidos peculiares, quase que exclusivamente japoneses (Aoki, 1990: 109). Também refletia, em parte, incidentes no plano internacional, a emblemática "Revolução Húngara" de 1956, com o conseqüente aumento da crítica ao regime soviético cada vez mais autoritário e repressivo, acarretando assim desilusão à causa comunista (ibid.).

A teoria das classes sociais de inspiração marxista teve mais fôlego. Um dos expoentes foi Ohashi Ryuken (1912-1983) que, tendo iniciado suas pesquisas ainda na década de 50, publicou Nihon no Kaikyû Kôsei (Composição das Classes no Japão) em 1971. Este estudo apresenta uma categorização das classes sociais do Japão em shihonka kaiky $\hat{u}^{161}$ (classe dos capitalistas), jieigyôshasô ${ }^{162}$ (estrato dos autônomos) e rôdôsha kaiky $\hat{u}^{163}$ (classe dos trabalhadores) e, tendo como base os censos realizados quinquenalmente entre 1950 e 1965, organizou uma tabela de classes sociais com os respectivos percentuais de distribuição populacional. Observando essa categorização, nota-se uma discrepância no critério de classificação, a começar pela nomenclatura (classe e estrato), além do fato de que os militares, policiais e agentes de segurança

emprega o termo "dansô", que significa "estrato", "camada", mas mais familiar às áreas de geologia, geografia e afins. A intenção era, certamente, evitar o emprego de "kaikyû", "classe".

${ }^{161}$ Formada por proprietário de empresas, seus diretores e ocupantes de postos de comando e funcionários públicos em postos de comando.

162 Composta por administradores de negócios próprios e seus familiares, como de agricultura e pesca, mineração e transportes, comércio e setor de serviços, e ainda por setores que demandam conhecimentos e técnicas especializadas.

${ }^{163}$ Fazem parte desta categoria: assalariados, portadores de conhecimentos e técnicas especializadas ou trabalhadores de escritório; trabalhadores nas atividades produtivas, como nos setores de agricultura e pesca, mineração e transportes; trabalhadores nas atividades não produtivas, como comércio e setor de serviços; desempregados. 
foram contabilizados como uma categoria à parte ${ }^{164}$. Não obstante esses problemas que atualmente são visíveis, a essência dessa categorização foi adotada por outros autores e batizado de "Sistema Ohashi", tornou-se quase uma unanimidade na academia na década de $70^{165}$.

Num dos exemplos de trabalho inspirado em Ohashi, e também tendo como fonte o censo nacional, Fukutake apresentou a estrutura de classes do Japão, de 1950 a 1985 (1989: 152). Nessa análise, Fukutake denominou “empresários familiares” os setores de agricultura, atividades florestais, atividade pesqueira, comércio, serviços e atividades técnicas:

Estrutura de classes da sociedade japonesa: 1950-85 (\%)

\begin{tabular}{cccccc}
\hline & $\mathbf{1 9 5 0}$ & $\mathbf{1 9 5 5}$ & $\mathbf{1 9 6 5}$ & $\mathbf{1 9 7 5}$ & $\mathbf{1 9 8 5}$ \\
\hline capitalistas & 1,9 & 2,0 & 3,6 & 5,9 & 5,8 \\
$\begin{array}{c}\text { “empresários } \\
\text { familiares" }\end{array}$ & 58,9 & 53,2 & 38,3 & 29,4 & 23,3 \\
trabalhadores & 38,2 & 43,6 & 56,9 & 63,3 & 69,5 \\
\hline
\end{tabular}

Fonte: Fukutake, 1989: 152

Observa-se, nesta tabela, o crescimento constante das classes "capitalista" e "trabalhadora", sendo que o primeiro teve estabilização na década de 70 para 80 , enquanto a classe de "empresários familiares" sofreu declínio sucessivo.

Entretanto, o conceito classe social [shakai kaikyû] parece não ter se desvencilhado da pecha de "comunista", em grande parte porque os autores que o adotaram ou pertenciam ao Partido Comunista ou tinham posições ideológicas próximas

\footnotetext{
${ }^{164}$ Segundo esse estudo, a distribuição populacional nas classes, em 1965, seria: classe dos capitalistas, $3,6 \%$; militares, policiais e agentes de segurança, $1,2 \%$; estrato dos autônomos, 38,3\%; e classe dos trabalhadores, 56,9\%. Apud Hashimoto, 1999: 8.

${ }^{165}$ Cf. Hara, 1979, apud Hashimoto, 1999.
} 
a ele, a começar pelo próprio Ohashi (Hashimoto, 1999: 12 e ss.). Assim, na academia japonesa, esse conceito ficou marcado pelo viés ideológico de conotação esquerdistarevolucionária, sendo evitado pela maioria dos autores ${ }^{166}$. Atualmente, praticamente apenas um autor o adota, mas de forma polêmica, como será verificado em seguida.

\subsubsection{2- Shakai kaikyû ("classe social"): um conceito controverso}

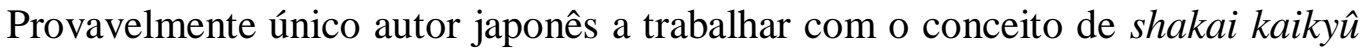
na atualidade, Hashimoto Kenji afirma seguir a teoria de Marx, Poulantzas e Wright para desenvolver a sua teoria de classes sociais (1999: 71; 2006: 34; 2007: 106). Dessa forma, indiretamente, Hashimoto se coloca como teórico marxista ${ }^{167}$, mas ao considerar, além da posse do capital e da "capacidade de empregar", itens estes inspirados em Wright, os fatores como consciência de pertencimento a uma classe, satisfação profissional, satisfação com a vida ("ser feliz"), posicionamento em relação à política pública de redução da desigualdade social, preferência partidária, entre outros, em suma, opiniões dos indivíduos, para classificar as classes, seu modelo teórico torna-se bastante distante do modelo marxista.

Ademais, se a diferença entre os conceitos de shakai kaikŷ̂ e shakai kaisô estrato social - reside no fato de que o primeiro pressupõe conflito de interesses e luta de classes (Seiyama et al., 2011: 283), o trabalho de Hashimoto, no máximo, faz o alerta

\footnotetext{
${ }^{166}$ Isso faz relembrar essa passagem escrita por Dahrendorf: “...quando o sociólogo usa o conceito de classe, ele não só deve explicar cuidadosamente em qual de seus múltiplos sentidos o está empregando, como também deve estar preparado para enfrentar objeções ditadas menos por considerações científicas que por preconceitos políticos" (1982: 15).

${ }^{167}$ Não somente o próprio Hashimoto, os demais autores também o consideram marxista. Por exemplo, cf. Hara; Seiyama, 1999: 230, nota 5.
} 
para o crescente aprofundamento da desigualdade social no Japão ${ }^{168}$, e acredita que a classe proletária não tem consciência política nem capacidade de mobilização para encontrar uma saída para essa situação e credita à "nova classe média”, conforme será definida adiante, a missão de liderar alguma mudança (2007: 227 e ss).

Combinando as variáveis e os fatores como ocupação, renda, satisfação de vida, preferência partidária e opiniões diversas como em relação à desigualdade social, Hashimoto classifica em cinco as classes sociais do Japão (2007: 128 a 136):

\section{Classes sociais do Japão segundo Hashimoto}

\begin{tabular}{|c|c|}
\hline classe & composição \\
\hline capitalista & empresários $^{169}$ \\
\hline nova classe média & assalariados (técnicos e cargos de gerenciamento) $^{170}$ \\
\hline antiga classe média & $\begin{array}{l}\text { autônomos não assalariados (agricultores, pescadores, } \\
\text { comerciantes e atividades técnicas-industriais) }{ }^{171}\end{array}$ \\
\hline
\end{tabular}

${ }^{168}$ Cf. "Aceitar o aprofundamento da desigualdade é uma afronta ao ser humano" (2006: 195).

169 Proprietários de empresas e lojas com mais de cinco funcionários, sendo que $72,8 \%$ são de microempresas com menos de 30 funcionários. Possuem renda familiar anual de 10,27 milhões de ienes (cerca de US\$ 103 mil), na média. 41,8\% consideram-se "felizes", 40,2\% estão satisfeitos com a própria profissão e $35 \%$ pensam ser "acima da média" em termos de estratificação. Apenas $32,7 \%$ concordam com a política de redução de desigualdade social. 65,8\% votam sempre nas eleições (no Japão, o voto não é obrigatório), 17,7\% tem filiação partidária, e 44,2\% apóiam o PLD (Partido Liberal Democrático, partido conservador que governou o Japão por mais de cinco décadas com breve intervalo no início da década de 90), e 7,8\% o PD (Partido Democrata, partido apoiado por sindicato e movimento trabalhista, atualmente no poder) demonstrando tendência conservadora (em 2007).

170 Possuem renda familiar anual de 8,24 milhões de ienes (cerca de US\$ 8,2 mil), na média. 26,7\% consideram-se "felizes", 25,1\% estão satisfeitos com a própria profissão e apenas 13,1\% pensam ser "acima da média" em termos de estratificação. Diferentemente da classe dos capitalistas, apenas $23,4 \%$ declaram apoiar o PLD e 13,2\% apóiam o PD, sendo que 52,6\% são favoráveis à política de combate à desigualdade social.

${ }^{171}$ Possuem renda familiar anual de 3,43 milhões de ienes (cerca de US\$ 3,4 mil), na média sendo que $32,8 \%$ consideram-se "felizes", $29,3 \%$ estão satisfeitos com a própria profissão e apenas 11,3\% pensam ser "acima da média" em termos de estratificação. A sua posição política é conservadora, 36,3\% apóiam o PLD e $12,0 \%$ o PD. $51,6 \%$ aprovam políticas combate à desigualdade social. Trata-se da classe que possui negócio próprio, mas atua diretamente nas atividades produtivas ou de serviços. 


\begin{tabular}{|c|l|}
\hline trabalhadores formais & assalariados formalmente contratados \\
\hline \multirow{2}{*}{ classe baixa } & $\begin{array}{l}\text { trabalhadores sem vínculo empregatício, vivem de } \\
\text { trabalhos ocasionais ou fazem "bicos", na maioria } \\
\text { dependentes dos pais }\end{array}$ \\
\hline
\end{tabular}

Nesse quadro, merece destaque o fato de que a quinta classe, a "classe baixa", não constava até o penúltimo trabalho de Hashimoto $(1999 ; 2006)$, o que reforça o caráter de destaque da deterioração das condições da classe menos favorecida do Japão, perfil do último trabalho (2007).

Organizando a estruturação de classes da sociedade japonesa segundo Hashimoto, em percentuais, temos:

Estrutura de classes da sociedade japonesa segundo Hashimoto (\%) classe 2007

\begin{tabular}{lc}
\hline capitalista & $5,4 \%$ \\
\hline nova classe média & $19,5 \%$ \\
\hline antiga classe média & $16,3 \%$ \\
\hline trabalhadores formais & $36,7 \%$ \\
\hline classe baixa & $22,1 \%$ \\
\hline
\end{tabular}

Fonte: Hashimoto (2007).

172 A sua renda familiar anual é de 3,47 milhões de ienes (cerca de US\$ 3,7 mil), na média. 21,1\% consideram-se "felizes", 16,9\% estão satisfeitos com a própria profissão e apenas 7,8\% pensam ser "acima da média" em termos de estratificação. O que caracteriza essa classe é baixo interesse político, $52,1 \%$ pensam que "a política não altera muita coisa, fica como está" e apenas 2,9\% afirmam pertencer a alguma agremiação política. Nessa classe, $24,6 \%$ se declara apoiar o PLD e $12,8 \%$ o PD.

173 Possui renda familiar anual de 1,51 milhões de ienes (cerca de US\$ 1,5 mil) e taxa de pobreza de $24,9 \%$. Apenas $16,9 \%$ consideram-se "felizes" e estão satisfeitos com a própria profissão, e apenas $4,7 \%$ pensam ser "acima da média" em termos de estratificação, demonstrando, portanto, alto índice de insatisfação em comparação com outras classes. 


\section{3- Estratificação social}

Ao rejeitar o termo shakai kaiky $\hat{u}$, os pesquisadores japoneses adotaram o shakai kaisô $^{174}$ - estratos sociais ou estratificação social ${ }^{175}$ - para identificar suas pesquisas. A questão é controversa, pois os mesmos autores empregam class como tradução de shakai kaisô para o inglês, como é o caso de Ishida Hiroshi, um dos expoentes de pesquisadores de shakai kaisô, para o qual adota a tradução "estrutura de classes" [class structure $](2010)^{176}$.

Para pautar a discussão, seria conveniente examinar, mesmo que de forma sucinta, o conceito de estratificação social.

\subsection{1- Estratificação social: o conceito}

O termo "estratificação social" tem origem na geologia, ao empregar metaforicamente "estratificação", que significa estratos e camadas de materiais que formam a crosta terrestre, para designar a estrutura de grupos sociais organizada em padrão de hierarquia em termos de riqueza, poder e prestígio (Inglis e Bone, 2006: 1).

Historicamente, a bibliografia apresenta duas formas de classificação da estratificação social. A mais restrita, é aquela proposta por Marshall, que define a estratificação social como a estrutura da sociedade formada por indivíduos ou grupos de

\footnotetext{
${ }^{174}$ Empregou-se a palavra "kaisô", que remete à ideia de "estrato" ou "camada", em contraste com "kaikyû", com a ideia de "ordem" ou "hierarquia", portanto, com conotação de dominação.

175 Tradução de strata ou stratification, segundo Seiyama (2011: 256).

${ }^{176}$ No entanto, kaisô ishiki é traduzido "consciência de status" [status consciousness] (2004). Nota-se que outros autores, como Kobayashi, por exemplo, traduziu kaisô kizoku ishiki como "consciência de classe", demonstrando que não há um padrão estabelecido (2008). Kikkawa emprega ambos, kaikyû kaisô ishiki (2008).
} 
indivíduos dispostos em “estratos ou camadas situados uns sobre os outros” (1967: 146) e a classifica em três tipos: classe social, casta e estamento (op.cit.: 147), inaugurando uma tradição seguida por outros autores ${ }^{177}$.

Outra corrente adota uma classificação mais ampla de estratificação social e tem origem nos autores que, nas décadas de 1960 e 70, diferenciavam a estrutura de classes da estratificação social, contrapondo-a: "estratificação e classes sociais são conceitos apresentados na literatura sociológica como opostos, estratificação referindo-se exclusivamente aos níveis jurídico e ideológico, classes sociais ao econômico" (Aguiar, 1974: 1).

Para Dahrendorf, a classe é "sempre uma categoria com o propósito de analisar a dinâmica do conflito social e suas raízes estruturais e, como tal, tem de ser estritamente separada do estrato, que é uma categoria com o propósito de descrever sistemas hierárquicos em um determinado ponto do tempo" (1982: 78) ${ }^{178}$. Sendo assim, Dahrendorf não admite a existência da "nova classe média", que "nunca foi, nem é provável que jamais chegue a ser uma classe em qualquer sentido do termo" e afirma que "os burocratas somam-se à burguesia assim como os trabalhadores de escritório somam-se ao proletariado", expressando apenas a tendência dessas duas classes se tornarem complexas e heterogêneas (op.cit.: 60).

Para tornar a questão mais complexa, como aponta Stavenhagen, “o conceito de classe social se identificou com o de estratificação social e chegou-se a uma completa

\footnotetext{
177 Ver, por exemplo, Littlejohn, 1976 e lanni, 1978.

178 Nesse sentido, Tominaga classificou oito "classes sociais" no Japão anterior à Segunda Guerra Mundial (1990: 351-357). Embora essa análise não seja inválida, pois retrata, de certa maneira, a estruturação da sociedade nesse momento histórico, é o caso de se discutir se uma classificação assim com tantos níveis de classificação serviria para o propósito de verificar as contradições econômicas e políticas do período.
} 
confusão dos fenômenos" (1966: 117), e os estratos passaram a ser chamados "classes" (op.cit.: 122).

Sobre esse assunto, Hirano critica o emprego despropositado do conceito de classe, tornando-o vazio de sentido histórico:

\begin{abstract}
"Entendemos que a não-discriminação entre os diversos graus de abstração e os diversos graus de concreticidade, ou entre o emprego genérico-abstrato e o emprego específico- particular do termo classes sociais, resultou num viés de interpretação, por seus epígonos, do significado teórico do conceito de classe social, transformando um conceito histórico e, portanto, determinado por uma dada produção social ou por um modo de produção social historicamente determinado, em suas várias configurações e dimensões sociais, em um conceito anistórico, invariável, imutável e universal. A preocupação focalizada na abstração e na generalização, sem a devida mediação pela realidade social historicamente dada, transformou esse conceito de tal modo que o fez permanecer ad infinitum na abstração geral, isto é, em vez de classe social determinada por formação histórico-social particular, transformou-a em classe social em geral" (2002: 121) $)^{179}$.
\end{abstract}

Para Stavenhagen, a principal diferença entre a estratificação e estrutura de classes reside no fato de que a estratificação cumpre papel conservador na sociedade, uma vez que ao mesmo tempo em que atenua e reduz as contradições, reforça a própria estratificação, enquanto que a estrutura de classes evidencia os conflitos e "constituem um fenômeno de ordem dinâmica, por excelência" (op.cit.: 147).

${ }^{179}$ Grifos do autor. 
Atualmente, alheios a essas críticas, os autores seguem conciliando as duas tradições, sem excluir a classe social ${ }^{180}$ e tratando de diversos aspectos como renda, ocupação, escolaridade, gênero, família, etc.

Tendo como pano de fundo esse panorama teórico, veremos em seguida como a discussão sobre a estratificação social foi e está sendo desenvolvida pelos autores japoneses.

\subsection{2- Shakai kaisô: estratificação e classe social}

Para Hashimoto, shakai kaisô se caracteriza por levar em consideração múltiplos fatores como estilo de vida, valores, preferência política, satisfação e senso de igualdade (2006: 31), além das variáveis básicas como idade, sexo e escolaridade, enquanto que shakai kaikyû é um conceito primordialmente econômico, restringindo-se, em última instância, se o indivíduo é possuidor ou não de capital (op.cit.: 32$)^{181}$.

De fato, os trabalhos sobre o shakai kaisô da sociedade japonesa têm abordado questões como gênero, família, mercado (Seiyama, 2000), assim como emprego, educação, estilo de vida e consumo (Sato; Ojima: 2011), apresentando uma diversidade que extrapola a abordagem feita na tradição do shakai kaikyû.

Mas o próprio Hashimoto, da corrente do shakai kaikyû, incorpora questões como satisfação e preferência política, conforme visto no item anterior.

Dessa forma, parece correta a observação de Seiyama, de que o emprego do termo shakai kaisô é uma alternativa para não empregar o shakai kaikŷ̂, impregnado de

\footnotetext{
${ }^{180}$ Cf. Kerbo (2007); Scott (2004); Crompton (1998).

${ }^{181}$ Para os organizadores da coleção Sistema de Estratificação Social Japonês, o emprego de kaisô visa a superar o conceito kaikyû, considerado "estreito e limitado" (Hara, 2000: iv).
} 
conotações negativas, mas sem que pudesse caracterizar e consolidar uma teoria distintiva (2011: 256).

5.4- Tendência ao centro da "identificação da posição social"

Os estudos sobre o shakai kaisô publicados atualmente têm como base os dados da pesquisa Shakaikaisô to Shakaiidô Chôsa, mais conhecida pela sigla SSM (Social Stratification and Social Mobility), iniciada em 1955 e realizada a cada década em escala nacional.

Essa pesquisa também tem averiguado junto aos informantes japoneses sobre o autoposicionamento dentro da sociedade, se eles se consideram pertencer, na estratificação social, à posição "alto", "médio alto", "médio baixo", "baixo alto" ou "baixo baixo"182. O objetivo dessa pergunta seria obter um indicador para averiguar o aspecto subjetivo da estratificação social e desigualdade social (Kobayashi, 2008: 111).

Para Hara e Seiyama, durante o período de 1955 a 1975, houve crescimento constante daqueles que responderam "alto do médio" e "baixo do médio", ou seja, de $7,1 \%$ a $23,4 \%$ e de $34,8 \%$ a $53 \%$, respectivamente, sendo que, a partir de 1975 , essas taxas se mantêm (24\% (1985) e 25,5\% (1995); 47,3\% (1985) e 46,8\% (1995)) (1999: $137)^{183}$ :

\footnotetext{
${ }^{182}$ Em japonês, respectivamente, jô, chû no jô, chû no ge, ge no jô e ge no ge.

183 Os percentuais sobre "alto" e "sem informação" são omitidos. Sobre a pesquisa SSM de 2005, há um estudo de Kobayashi que apresenta o resultado: alto do médio 16,7\%; baixo do médio 38,9\%; alto do
} 
“Identificação da posição social” de 1955 a 1995

\begin{tabular}{|c|c|c|c|c|c|}
\hline & 1955 & 1965 & 1975 & 1985 & 1995 \\
\hline alto do médio & $\overline{7,1}$ & 12,1 & 23,4 & 24,0 & 25,5 \\
\hline $\begin{array}{ll}\text { baixo } & \text { do } \\
\text { médio } & \end{array}$ & 34,8 & 42,7 & 53,0 & 47,3 & 46,8 \\
\hline alto do baixo & 37,7 & 32,2 & 16,7 & 17,5 & 15,9 \\
\hline $\begin{array}{l}\text { baixo } \\
\text { baixo }\end{array}$ & 18,6 & 8,8 & 3,9 & 5,9 & 5,8 \\
\hline
\end{tabular}

Fonte: Hara e Seiyama, 1999: 136.

Verifica-se, dessa forma, que de 1975 a 1995, cerca de 70\% dos informantes declararam pertencer ao "estrato médio" da sociedade japonesa.

Esse resultado, juntamente com outros semelhantes verificados na pesquisa governamental $^{184}$, propiciou intensos debates no meio acadêmico japonês, pois não correspondia à observação empírica, ou seja, não havia correspondente ascensão da classe trabalhadora para a classe média no período, e também considerando que as décadas de 1950 a 1970 correspondiam à chamada fase do "milagre japonês", tal fenômeno continuou a ser observado mesmo após o término dessa fase de crescimento econômico, por volta de $1975^{185}$.

Há algumas hipóteses para explicar esse fenômeno de tendência ao centro da “identificação da posição social".

baixo $22,0 \%$ e baixo do baixo 6,8\% (2008: 114). Entretanto, esses números devem ser analisados com ressalva, pois ocorreu a alteração de metodologia (ibid.).

${ }^{184}$ A "Pesquisa de Opinião Pública sobre a vida da População Nacional" [Kokumin Seikatsu ni kansuru Seron Chôsa], realizada desde 1949. Em 1958, cerca de 70\% responderam pertencer ao estrato médio, e esse número chegou a 90\% na década de 1970 (Kanbayashi, 2011: 158). É necessário observar que nessa pesquisa, adota-se "médio do médio", aumentando para três as opções do "médio".

${ }_{185}$ Curiosamente, a pesquisa SSM também verificava a consciência de pertencimento à classe social dos informantes, pedindo que escolhesse entre classe capitalista, classe média e classe trabalhadora [shihonka kaikyû, chûsan kaikyû e rôdôsha kaikyû]. Nas cinco edições inicias, a maioria absoluta respondeu pertencer à classe trabalhadora, em percentuais, respectivamente: 73,6 (1955), 62,4 (1965), 69,7(1975), 63,9 (1985) e 64,6(1995) (Hara; Seiyama, 1999: 137). Na edição de 2005, essa pergunta foi abolida (Kikkawa, 2008: 132, nota 1). 
Imada e Hara (1979) ${ }^{186}$ atribuem as causas dessa convergência para o centro à intensa mudança na condição social, fruto da industrialização e do aumento da escolaridade entre os informantes. Ou seja, segundo essa hipótese, nem todos apresentam o perfil médio, mas num exemplo restrito, um trabalhador "colarinhobranco" de escolaridade alta, mas de baixo rendimento, responderia ser do estrato "médio" em função da expectativa de ascensão na carreira, enquanto outro trabalhador "colarinho-azul" de escolaridade baixa, mas de rendimento maior, responderia de maneira semelhante pela influência que possui no local de trabalho.

Kosaka (2006) por sua vez, afirma que as pessoas possuem uma "imagem de estratificação" do que é ser "alto", "médio", etc. Mas essa imagem tende a ser mais precisa quando o estrato em referência é familiar, e mais imprecisa quando é distante do cotidiano, e a explicação de Kosaka é que essa imprecisão que faz, na avaliação, as pessoas tenderem a responder "médio". Em outras palavras, segundo Kosaka, há membros do estrato alto e do baixo "infiltrados", inflando o médio.

Seiyama atribui a causa à defasagem de percepção que as pessoas têm do desenvolvimento econômico da sociedade como um todo e à melhoria da própria condição social (1999: 140). Segundo esse autor, a avaliação de ser "alto", "médio" ou "baixo" deveria ser relativa e proporcional à estratificação da sociedade como um todo, mas num momento de rápido crescimento econômico, as pessoas tendem a responder considerando apenas a melhoria da própria condição de vida. Assim, um informante poderia responder ser "médio", por ter conseguido comprar um bem qualquer recentemente, embora ainda continue pertencendo ao estrato "baixo".

\footnotetext{
${ }^{186}$ IMADA, T.; HARA, J. Shakaiteki Chii no Ikkansei to Hiikkansei (A Coerência e Incoerência da Posição Social). In: TOMINAGA, K. (org.). Nihon no Kaisô Kôzô (A Estratificação Social do Japão). Tóquio: Tokyo Daigaku Shuppankai, 1979. Apud Sudo, 2010.
} 
Sudo (2010) afirma haver correspondência entre a escolaridade e a identificação na posição social, e que a escolaridade "de chegada", ou seja, a escolaridade que o indivíduo atingiu em comparação com a escolaridade do pai, tende a orientar essa avaliação.

5.5- Estratificação, classe social e hierarquia

Ao pretender analisar a hierarquia social tendo como referência a estratificação ou a classe social, as informações acima precisam ser levadas em conta. De imediato, é possível extrair dessa discussão que os indivíduos apresentam dificuldades para se situar na estratificação social ou na estrutura de classes e que, quando o fazem, com frequência podem cometer equívocos. Mais do que isso, numa sociedade em que até pouco tempo atrás cerca de 70 a $80 \%$ de sua população se situava como sendo do estrato médio, haveria dificuldade para relacionar hierarquia e estrato ou classe social.

Não obstante, há de se convir que seja no mínimo discutível pedir para que os informantes se situem entre "alto", "alto do médio", etc., sem nenhuma referência comum, pois, nesse caso, o critério a ser adotado é subjetivo ${ }^{187}$.

Para evitar as armadilhas que a interpretação diferente dos termos como "classe social", "estrato", “classe média", posição "alto" etc. pode acarretar, na nossa pesquisa, elaboraram-se as perguntas empregando diretamente os termos "rendimento" e "escolaridade", variáveis comumente empregadas para se estabelecer a estratificação.

\footnotetext{
${ }^{187}$ Segundo Stavenhagen, um pesquisador norte-americano, R. Centers, considerou na pesquisa apenas a opinião que as pessoas têm de sua própria posição na estratificação, como ocorre na SSM, e chegou à conclusão de que a grande maioria dos cidadãos dos EUA pertence à "classe média" (1966: 119). Embora não seja possível tirar conclusões, isso pode ser um indicador de que feita a pesquisa nessa concepção, a tendência é de as posições convergirem para o centro.
} 
Nesse sentido, em vez de perguntar "você considera que a classe social define a hierarquia" ou "você considera que quem pertence à classe superior deve ser respeitado?", foi perguntado “considera que quem tem mais rendimento é superior a você?"' (8.18 do anexo).

O resultado mostrou um predomínio total dos que responderam "não considero" $(64,2 \%)$ e "não considero em absoluto" (30,9\%), totalizando $95,1 \%$, sendo que nenhum informante respondeu "considero":

Tabela 4: Distribuição das respostas para a pergunta se o informante considera que quem tem rendimento maior é superior a ele

\begin{tabular}{cccccccc}
\hline & considero & $\begin{array}{c}\text { considero } \\
\text { um pouco }\end{array}$ & $\begin{array}{c}\text { não } \\
\text { considero }\end{array}$ & $\begin{array}{c}\text { não considero } \\
\text { em absoluto }\end{array}$ & não sei & s/inf. & Total \\
\hline No. & 0 & 3 & 52 & 25 & 0 & 1 & 81 \\
$\%$ & 0 & 3,7 & 64,2 & 30,9 & 0 & 1,2 & 100 \\
\hline
\end{tabular}

Para a pergunta "considera que quem tem mais escolaridade é superior a você?" (8.19 do anexo), o resultado foi semelhante: $63 \%$ dos informantes responderam "não considero", 29,6\% escolheram "não considero em absoluto" e ninguém respondeu "considero":

Tabela 5: Distribuição das respostas para a pergunta se o informante considera que quem tem mais escolaridade é superior a ele

\begin{tabular}{cccccccc}
\hline & considero & $\begin{array}{c}\text { considero } \\
\text { um pouco }\end{array}$ & $\begin{array}{c}\text { não } \\
\text { considero }\end{array}$ & $\begin{array}{c}\text { não considero } \\
\text { em absoluto }\end{array}$ & não sei & s/inf. & Total \\
\hline No. & 0 & 5 & 51 & 24 & 0 & 1 & 81 \\
$\%$ & 0 & 6,2 & 63,0 & 29,6 & 0 & 1,2 & 100 \\
\hline
\end{tabular}


Para a pergunta "considera que quem ocupa posição social acima de você é superior a você?" (8.20 do anexo), a resposta foi mais equilibrada. Somando aqueles que responderam "considero" $(13,6 \%)$ e "considero um pouco" $(26 \%)$, praticamente iguala aqueles que responderam "não considero" (39,5\%):

Tabela 6: Distribuição das respostas para a pergunta se o informante considera que quem ocupa posição social acima dele é superior a ele

\begin{tabular}{cccccccc}
\hline considero & $\begin{array}{c}\text { considero } \\
\text { um pouco }\end{array}$ & $\begin{array}{c}\text { não } \\
\text { considero }\end{array}$ & $\begin{array}{c}\text { não considero } \\
\text { em absoluto }\end{array}$ & não sei & s/inf. & Total \\
\hline No. & 11 & 21 & 32 & 13 & 1 & 3 & 81 \\
$\%$ & 13,6 & 26,0 & 39,5 & 16,0 & 1,2 & 3,7 & 100 \\
\hline
\end{tabular}

Talvez seja necessário fazer um reparo neste item, no sentido de que o termo “posição social" esteja vago, e pode ter sido interpretado de maneiras diferentes ${ }^{188}$. Assim, se o termo foi interpretado como alguma autoridade hierárquica na empresa onde trabalha, por exemplo, seria compreensível que um número significativo de informantes tenha respondido "considero" $(13,6 \%)$, dada a importância do local de trabalho na avaliação da hierarquia, como será verificado no Capítulo 6. Mas se essa hipótese está correta, aparentemente é contraditório com o percentual que responderam "não considero em absoluto", que somado com "não considero", atinge a maioria $(55,5 \%)$. O que isso significa? É plausível que esses últimos tenham interpretado o termo "posição social” como autoridade pública, e não como seu chefe ou presidente da empresa onde trabalha,

\footnotetext{
${ }^{188}$ Em japonês, shakaiteki chii, "posição social", e shakaiteki chii no aru hito, "pessoa que ocupa posição social", é geralmente relacionada com aqueles que ocupam cargo público, como político, professor universitário, funcionário público, diretor de escola etc.
} 
e nesse caso, há um distanciamento em termos de estratificação ou classe social. Isso somado com o resultado dos itens sobre o rendimento e a escolaridade, sugere que a noção de respeito, ou a manifestação da consciência hierárquica, ocorre num nível mais próximo dos informantes, e não no nível que se convencionou denominar macrossociológico. É necessário observar, pois, como isso ocorre nos níveis microssociológicos, como local de trabalho e família.

\section{6- Considerações finais}

O presente capítulo foi iniciado com uma síntese das teorias sobre as classes sociais de Marx e Weber, que foi feita com o objetivo de servir de introito para a apresentação das principais obras que versam sobre a estrutura da sociedade japonesa. Essas obras, de forma adequada ou não, creditam a matriz teórica a esses dois autores clássicos, ou mesmo não reconhecendo explicitamente, são inspiradas neles.

Seria pertinente frisar, nesse ponto, por que não se realizou nessa seção uma análise de classes da sociedade japonesa, tal qual feita originalmente por Marx.

A análise de classe social pressupõe uma sociedade de classes e o modo de produção capitalista, e o conceito clássico de classe social foi criado para analisar uma determinada sociedade num determinado momento histórico, o advento do capitalismo moderno, como afirma Hirano:

“As classes sociais adquirem suas plenas características, com grau máximo de pureza, com o advento da sociedade moderna, do Estado moderno, da indústria moderna, em poucas palavras, com o pleno desenvolvimento do capitalismo moderno. É neste que se 
manifestam as classes sociais fundamentais produzidas pela articulação capitalcapitalista, trabalho assalariado - classe operária." (2002: 194).

"Em suma, as classes sociais são categorias históricas e transitórias e são determinadas pela transição do feudalismo ao capitalismo moderno. O referencial básico é a produção social historicamente determinada, ou seja, o modo de produção capitalista moderno" (2002: 133) .

Portanto, elaborado inicialmente para analisar a sociedade ocidental, notadamente a Inglaterra, onde o capitalismo se apresentava no estágio mais avançado, esse modelo de análise não poderia ser imediatamente aplicado no Japão, e mesmo que fosse, com a devida adaptação, poderia ser somente a partir das primeiras décadas do século XX, quando, finalmente, é possível afirmar que surge uma sociedade capitalista com classes sociais.

Acima de tudo, vale repetir que o presente estudo visa a elucidar a hierarquia social japonesa contemporânea e não a estrutura social japonesa. As duas podem estar vinculadas, como no passado, em que a estrutura social foi a base da qual se estabeleceu a estrutura hierárquica, ou seja, a sociedade estamental no período feudal japonês, que serviu de base para a constituição da estrutura hierárquica entre guerreiros, camponeses, artesãos e comerciantes. No entanto, nosso foco é a sociedade japonesa hodierna. Como se observou no capítulo anterior, o Japão se reergueu dos escombros da guerra sob a égide da democracia e da igualdade, imposta pelos americanos, suprimindo os privilégios existentes até então, salvo os da família imperial. Atualmente, não existem elementos que relacionem a estrutura de classes com a consciência hierárquica, não há valores que identifiquem superioridade por pertencer a uma classe. E mesmo no sentido 
de "classe" como sinônimo de "estrato", não há vinculação com a consciência hierárquica, pois status ou posição social, assim como a escolaridade, não são vinculados ao sentimento de respeito, como foi verificado nas amostragens da nossa pesquisa.

Conforme discutido no Capítulo 2, a classe social entrou na pauta da discussão porque Benedict havia mencionado a mesma como uma das referências para a determinação da hierarquia. Do acima exposto, da discussão sobre o conceito de classe e estrato, é possível afirmar que a "classe" mencionada por Benedict referia-se ao emprego no sentido amplo, no sentido de estrato social, e ainda num nível de diferenciação mais específica que seria o estrato militar, que estava no poder até o término da guerra, refletindo a circunstância histórica, conforme visto no capítulo 4.

Toda essa conclusão não diminui a importância da análise de classes, como afirma Miliband, para quem a análise de classe "só poderia tornar-se irrelevante com o advento de uma sociedade sem classes" (1999: 501). A questão é que ela não é feita nos moldes propostos por Marx, e mesmo que fosse, pouco contribuiria para elucidar a hierarquia social do Japão.

A constatação de que a consciência de hierarquia e a expressão de respeito calcada nessa consciência não estão relacionadas com a classe ou estratificação remete a questão para a instância que Marshall denominou "status social” posicional, "a posição social atribuída pelos valores convencionais correntes na sociedade ao grupo ou categoria do qual o indivíduo é um representante" (1967: 153), que possui uma autonomia relativa em relação à estratificação ou estrutura de classes, pois, na essência, é um conceito cultural (op.cit.: 168). Entretanto, esse conceito ainda está vinculado a um nível coletivo, no caso a um grupo que precisa avalizar o status, como afirma Marshall: 
"O status social, como dissemos, é a localização ou posição na sociedade, e pode ser falso descrevê-lo em termos da relação entre dois indivíduos. Pois o status social descansa num julgamento coletivo ou, melhor ainda, num consenso de opinião no grupo. Ninguém pode por si mesmo conferir status social a alguém, e se a posição de um indivíduo fosse avaliada de maneira diferente por cada um daqueles com quem o referido indivíduo interage, então não haveria absolutamente nenhum status social. Em outras palavras, o status social é a posição em função dos valores sociais correntes na sociedade. Tem, pode-se dizer, um caráter convencional.” (op.cit.: 152).

A relação hierárquica japonesa certamente possui essa dimensão coletiva, é ancorada na opinião de grupo, mas apresenta, também, uma definição na relação entre dois indivíduos, como será analisado nos capítulos seguintes. Ademais, conforme a discussão no Capítulo 2, a hierarquia precisa ser estudada não somente do ponto de vista dos que avalizam, portanto, um fator externo, mas também pelo aspecto da consciência dos indivíduos como agentes, que extraem da estrutura hierárquica não somente as regras, mas também os recursos para a ação.

Nesse sentido, parece-nos acertada a definição de Giddens, no que se refere às posições sociais: elas são "constituídas estruturalmente como interseções específicas de significação, dominação e legitimação que se relacionam com a tipificação dos agentes" e ainda envolvem a "especificação de uma "identidade" definida numa rede de relações sociais" (1989: 67).

Dessa forma, cabe, no próximo capítulo, verificar as instâncias mais específicas onde as posições sociais podem ser verificadas na sociedade japonesa: família, escola e local de trabalho. 


\section{Capítulo 6}

\section{Família, escola e empresa}

\section{1- Introdução}

No final do capítulo anterior, a hierarquia social japonesa foi relacionada com a posição social, e esta conclusão remeteu-a para as instâncias mais próximas do indivíduo: família, escola e local de trabalho. Cabe, então, neste capítulo, realizar um estudo mais detalhado dessas instituições.

Nessa tarefa, o passado, o presente e, em alguns casos, o futuro dessas instituições serão abordados, destacando-se a estrutura hierárquica e a manifestação da hierarquia, confrontando essas com o resultado da pesquisa realizada.

Giddens destaca a rotina, entendida como "tudo o que é feito habitualmente", como um elemento básico da atividade social cotidiana, uma vez que é ela que permite a recriação constante da estrutura (1989: XIX). E ainda, afirma que a "rotinização é vital para os mecanismos psicológicos por meio dos quais um senso de confiança ou segurança ontológica é sustentado nas atividades cotidianas da vida social” (ibid.).

Dessa forma, a análise desenvolvida nesse capítulo também servirá para demonstrar o quanto a hierarquia está presente no cotidiano do indivíduo japonês desde a tenra idade, e como isso está "rotinizado" ao longo da vida; ao mesmo tempo, é ela que fornece os recursos para levar adiante a vida social dos japoneses. 


\section{2- Família}

A família pode ser definida de diversas formas, de acordo com o propósito e finalidade do estudo pretendido, e mesmo nas Ciências Sociais, não há uma definição universal que possa abarcar totalmente a sua estrutura, natureza e função social (Rajkai, 2010: 52).

Em Sociologia, os estudos clássicos sobre a família destacaram o formato de “família nuclear”, constituída por pais e filhos, e a divisão sexual do trabalho (“o esposo trabalha fora e a esposa cuida do lar") como características representativas do modelo de família da sociedade industrial (Parsons e Bales, 1955), ou destacaram a centralidade do casal, no modelo de "família conjugal" (Goode, 1963). Inspirados principalmente na sociedade americana e europeia, esses estudos pressupunham que, em escala mundial, a família convergiria para esses modelos pretensamente "universais" que seus autores advogavam, o que não foi constatado de imediato, motivo pelo qual sofreram críticas já na década de $1960^{189}$.

Os estudos mais recentes sobre a família se desenvolveram em matizes diversos (Senda, 2011: 11-15): alguns enfatizam os membros consanguíneos, excluindo-se os membros não-consanguíneos da definição de família ${ }^{190}$; outros destacam a família como instituição que garante a sobrevivência de seus membros e a procriação; outros estudos destacam a sua importância na criação dos filhos; outros realizam a análise da família pelo aspecto da valorização da intimidade de seus membros; há os que estudam a realidade e transformação dos laços afetivos dos familiares, etc. Outros autores ainda

\footnotetext{
${ }^{189}$ Ver, por exemplo, Litwak e Szelenyi, 1969.

${ }^{190}$ Embora no senso comum a consanguinidade pareça ser o critério primeiro da família, historicamente, nem sempre foi assim. Nesse caso, os membros não consanguíneos referem-se a agregados e parentes que
} 
defendem que o conceito de família só passa a ter algum significado quando se leva em consideração o que seus membros pensam e interpretam a respeito, em suma, o que os familiares consideram família, dentro da realidade do seu dia a dia (Kataoka, 2009).

Como se pode verificar, o estudo da família se ramifica de uma forma muito diversificada, quase que infinita; todavia, para o presente trabalho, interessa aquela abordagem que focaliza a estrutura da família, que cria as condições do surgimento da hierarquia, e procura entender como a relação hierárquica se manifesta no relacionamento entre seus membros.

Entretanto, esse estudo não pode ser desvinculado das considerações sobre as condições sócio-político-econômicas da sociedade onde a família está inserida, que fazem parte da história e da cultura. A família não pode ser considerada sem verificar a relação com o regime de governo vigente, as condições econômicas, enfim, o sistema político e o sistema econômico da sociedade onde está inserida. Como disse Elias, muitas vezes "as famílias são representadas como entidades autônomas ou até como elementos fundamentais - os "tijolos" - com que se constroem as sociedades", mas essa visão é equivocada, porque:

“(...) quando se observa que as configurações de pessoas a que nos referimos como "famílias" variam enormemente, tanto em sua estrutura quanto em seu tipo, e quando se indaga sobre a razão dessa variação, logo se descobre que as forças responsáveis por essas diferenças não se encontram no interior das próprias famílias. Só podem ser encontradas nas unidades maiores de que elas fazem parte.” (2000: 90)

coabitavam a mesma moradia, e que no caso japonês tem importância na discussão da casa, como se verá adiante. 
A família japonesa passou por profundas transformações, e na era contemporânea, o divisor de águas foi a Segunda Guerra Mundial. Como foi visto no Capítulo 3 e 4, a derrota do Japão nessa guerra resultou em uma ruptura da ordem social vigente, acarretando, como consequência, transformações sociais profundas, incluindose as relações sociais. Assim, para o propósito de análise, a família japonesa será dividida em duas fases: anterior à guerra e posterior à guerra ${ }^{191}$.

6.2.1- Período até a Segunda Guerra Mundial: predominância de ie, a "família tradicional"

A palavra-chave para a compreensão da família japonesa desse período é ie, "casa", que na bibliografia corrente comporta dois significados distintos, porém correlacionados $^{192}$. No sentido restrito, significa "família”, tal qual estabelecida pelo Código Civil do período Meiji, que foi extinto no pós-guerra, em 1947. No sentido amplo, significa o sistema familiar tradicional do Japão, existente pelo menos desde o século XII, e que serviu de inspiração para a "família", do período Meiji.

\footnotetext{
${ }^{191}$ Nos estudos sobre a família japonesa, existe um grande debate sobre a "família tradicional" e a "família moderna", com dificuldade para se chegar a um consenso no que se refere à definição desses termos e a partir disso determinar a caracterização da família japonesa atual (cf. Senda, 2011; Ochiai, 2000; Ueno, 1994). É uma questão complexa que envolve não somente o aspecto conceitual, mas a diferença entre o Ocidente e o Oriente, cujos pormenores não serão aqui desenvolvidos, por estarem fora do nosso propósito.

${ }_{192}$ Para efeito de ilustração, numa rápida consulta nos dicionários de língua japonesa contemporânea, pode se verificar que a palavra ie é polissêmica e pode significar: a) prédio que serve de moradia (casa); b) lugar onde se mora (residência); c) lar; d) linhagem, descendência herdada de antepassados (família); e) status da família na comunidade; f) bens de uma família; g) grupo de pessoas constituído por chefe (koshu) e seus familiares no antigo Código Civil.
} 
Neste estudo, designaremos por $\operatorname{casa}^{193}$ o sistema familiar tradicional, ou seja, a segunda acepção da palavra ie, e "família tradicional", em itálico, quando se refere especificamente à família estabelecida pelo Código do período Meiji.

A família tradicional foi instituída pelo Código Civil de Meiji, na esteira da criação de um Estado forte e centralizador, conforme anteriormente mencionado. Como visto no Capítulo 3, a Restauração Meiji foi conduzida pelos guerreiros e, como que naturalmente, a institucionalização das práticas próprias deste estamento foi a tônica na organização da concepção do Japão moderno. Nesse contexto, é inegável que o modelo de família hierarquizada, tendo nítidas definições e distinções no que se refere aos direitos e prerrogativas, acabasse se tornando o modelo a ser seguido e estimulado ${ }^{194}$, principalmente na educação escolar. Por exemplo, nos livros didáticos da década de 1870, ensinava-se, por meio de contos e fábulas, que os filhos deviam obediência incondicional e irrestrita aos pais ${ }^{195}$, no extremo, sacrificando a própria vida, mesmo que esses não tivessem a razão ou fossem abusivos (Muta, 1996: 88).

Com viés autoritário e poder absoluto do pai, a família tradicional certamente teve inspiração na casa e possui características em comum, mas esta apresenta contornos mais abrangentes.

Os autores japoneses, que inicialmente se debruçaram sobre a casa, se dividiram em duas linhas de análise: uma que destaca a relação de consanguinidade e parentesco (Kitano, 1976) e outra que destaca o aspecto econômico em primeiro plano, somado a questões como a religiosa e moral, enfim, às questões que permeiam os valores da organização familiar (Aruga, 1971). A principal divergência entre esses dois autores era

\footnotetext{
${ }^{193}$ Essa tradução é inspirada na historiografia ocidental, como por exemplo "casa de Lancaster", embora, no caso japonês, a casa não tenha sido exclusivamente uma instituição da nobreza, como veremos adiante.

${ }^{194}$ Como será analisada adiante, a casa foi a base da qual foi estruturada a sociedade estamental no período feudal japonês (Hirayama, 1995: 174).
} 
sobre o problema da existência do membro não consanguíneo residente na casa. Kitano, por destacar a relação de consanguinidade, minimizava a importância deste, enquanto que Aruga o considerava fundamental para a compreensão da casa.

A despeito dessas diferenças, há um consenso entre esses autores no que se refere à essência da casa, como segue:

a) a casa era uma unidade de organização social e produção econômica, além de ser referência para o governo na execução da política pública ${ }^{196}$; o status do indivíduo era determinado pelo status da casa à qual pertencia;

b) a casa era comandada por um chefe, normalmente o pai;

c) a transição era feita, em princípio, de pai para o primogênito, filho legítimo, ou seja, sob o critério de descendência direta. Essa regra demonstra que a transição entre as gerações ocorria no sentido vertical, ou seja, não pressupunha, pelo menos formalmente, que o irmão mais novo do pai, por exemplo, fosse declarado sucessor. Quando isso ocorria, por absoluta falta de alternativa, assumia na condição de filho adotivo, e não de irmão, como será explanado no item "e";

d) o princípio que regia os membros da casa era a sua continuidade: a casa era concebida para ser, a priori, perene, e deveria ser preservada a qualquer custo ${ }^{197}$;

e) como condição dessa perenidade, a casa era uma instituição transgeracional, que se estendia ao longo de gerações, e que deveria ser preservada mesmo que admitindo membros não consanguíneos para sua perpetuação. Quando o casal não possuía filhos, a alternativa seguida era o recurso da adoção [yôshi], em que uma pessoa, seja parenta ou não, era "adotada" para ser o sucessor. Muitas vezes, quando o casal tinha apenas uma

\footnotetext{
${ }^{195}$ Entenda-se "pai”, pela posição absoluta e pelo poder que detinha na família tradicional.

${ }^{196}$ A casa poderia ser considerada como a menor unidade da aldeia, e, nesse sentido, tinha caráter de extensão do poder executivo, no sentido atual (Hasegawa et al., 1991: 13). A tributação, assim como as obrigações de prestação de serviços, era aplicada para as casas e não para os indivíduos.
} 
filha, era o genro que ocupava a posição do filho herdeiro [mukoyôshi]. Conclui-se, assim, que o que prevalecia era a preservação da linha sucessória, em que o fator consanguinidade podia ser relegado para garantir esse fim;

f) ao longo do tempo, consolidou-se um princípio, em termos de composição, que a casa fosse formada por duas gerações, o casal e seus filhos. Isso se deve ao princípio de que somente o primogênito possuía a prerrogativa de ser herdeiro, e os demais filhos deveriam abandonar a casa assim que se casassem, constituindo o próprio $i e^{198}$. O mesmo acontecia com as filhas, exceto no caso em que não possuíssem irmãos, devendo se casar com o "filho adotivo".

Para que a casa funcionasse a contento, como acima descrito, e para sua perpetuação, era indispensável que existisse uma hierarquia rígida e prevalecesse a autoridade do chefe da casa, no caso kachô. Isso se expressava na submissão ao mandante do ie por parte dos membros inferiores da casa e o sacrifício em nome do bem-estar e perpetuação da casa; na vigilância da conduta e nas sanções em caso de infração, em suma, em coerção sobre a vida social e privada de seus membros. Esse domínio sobre o indivíduo também era reforçado pela valorização da coesão interna e distinção em relação “aos de fora”, destacando, muitas vezes, a própria superioridade ${ }^{199}$.

\footnotetext{
${ }^{197}$ Por exemplo, Sato (2010) descreve como os daimiôs, na Era Tokugawa, traçavam estratégias para a sobrevida da própria casa.

${ }^{198}$ A esse respeito, são ilustrativos os casos da família tradicional de Han, China, e da Índia, em que os homens permaneciam na família original, mesmo casados, constituindo a chamada grande família, de 50 a 60 membros. Nessas famílias, os membros homens possuíam os mesmos direitos e detinham a mesma autoridade, independentemente da ordem de nascimento, sobre os assuntos da família. Assim, embora o mais velho seja considerado superior, os irmãos formavam uma relação de horizontalidade, em que prevalecia a cooperação e não a subordinação, como no caso japonês (Nakane, 1977: 37).

${ }^{199}$ Como escreveu Elias, essa tática é universal: "A atribuição de falhas - e também de qualidades positivas - a indivíduos que pessoalmente nada fizeram para merecê-las, pelo simples fato de pertencerem a um grupo julgado digno delas, é um fenômeno universal. É comum as pessoas desconcertarem ou silenciarem aqueles de quem discordam ou a quem estão combatendo, jogando-lhes na cara algum termo grupal depreciativo e infame ou algum boato vergonhoso que se refira a seu grupo, desde que tais pessoas
} 
Os principais autores que estudaram a família no início do século passado escolheram como objeto de pesquisa os casos da zona rural do Japão (Aruga, op. cit.; Kitano, op.cit.), fazendo com que a casa seja comumente relacionada ao meio rural, portanto, como fenômeno encontrado entre os camponeses. Mas a origem dela remonta à desintegração do Estado legista ${ }^{200}$, e teria surgido inicialmente entre os nobres na segunda metade do século XII, e entre os guerreiros [bushi] nos séculos XII a XIV, consolidando-se no período de Guerras (século XVI) (Sugawara, 2007; Kasaya, 1999; Hirayama, 1995) ${ }^{201}$. E entre os citadinos [chônin], a casa tem registros no século XVII (Hasegawa et al., 1991: 15), e entre os camponeses, no início do século XIX (Hirai, 2008). Portanto, o surgimento da casa entre os camponeses é mais recente.

A casa era uma instituição que visava à continuidade e reprodução não somente da família em si, mas de toda a herança material, a começar pela propriedade territorial e imobiliária, os recursos acumulados e, sobretudo, da honraria adquirida, que devia ser transmitida pelos sucessores. Nesse quesito, a própria condição de consanguinidade era relegada ao segundo plano.

A tradição nesse contexto deve ser interpretada não somente como preservação de valores e costumes cristalizados pelas gerações, mas também como expressão das relações sociais representativas do sistema social antigo que deixou de existir, ou que sobrevive em setores minoritários da sociedade. Logo, é diferente falar da família na sociedade tradicional e da família tradicional, uma vez que esta última pode ser encontrada na sociedade moderna e contemporânea.

pertençam a um grupo que tenha sucesso em afirmar seu status superior em comparação ao de seus adversários" (2000: 131).

${ }^{200}$ Cf. Capítulo III.

${ }^{201}$ Há quem identifique em uji (cf. Cap. III) características de confederação de casas, defendendo assim, o surgimento da casa no século VII (Nakamura, 1995). 
Mesmo na atualidade, as características da casa são herdadas sob a forma de iemoto, sistema tradicional encontrado em artes como ikebana (arranjo floral), cerimônia do chá, dança tradicional, artes cênicas como kabuki, nô e rakugo, e algumas artes marciais, como kendô e kyûdô, cujas atividades são centralizadas na figura do mestre, que transmite a legitimidade, a técnica e os conhecimentos para seus filhos, de forma hereditária ${ }^{202}$.

\subsection{2- Período pós Segunda Guerra Mundial: o novo modelo de família}

Mostrou-se, na seção anterior, que a hierarquia no seio da família japonesa era estruturada a partir da dominação patriarcal. A partir do momento em que essa dominação deixou de existir, foi corroída a base da hierarquia familiar, pelo menos no sentido de mandonismo paternal e submissão dos demais membros. É nesse sentido que a família contemporânea japonesa é situada como sucessora da família tradicional e considerada produto da modernização do Japão, do processo histórico da industrialização e do estabelecimento do Estado moderno (Ochiai, 2000; Ueno, op.cit.).

Como características da família contemporânea, podem ser elencadas a estrutura menor, com menos membros em termos de filhos e de gerações, e uma mudança na própria concepção da função da família e do que deve prevalecer no relacionamento intrafamiliar.

O fator estrutural, ou o aumento da família nuclear, como consequência da diminuição dos membros da família e a opção dos filhos de residir separadamente dos pais, embora importante, por si só, não explica a mudança da postura em relação à

\footnotetext{
${ }^{202}$ Um estudo abrangente sobre o iemoto se encontra em Nishiyama, 1982.
} 
hierarquia familiar. Em estudo de 1937, Toda indica que já na década de 1920, mais da metade das famílias japonesas possuíam a estrutura de família nuclear, ou seja, eram compostas de duas gerações, de pais e filhos ${ }^{203}$ (2001: 311).

Em primeiro lugar, há a transformação na relação pais e filhos. Diferentemente da família tradicional, na qual o distanciamento e o respeito ${ }^{204}$ eram a tônica nessa relação, a nova família apresenta maior envolvimento entre pais e filhos, ou, talvez, maior intimidade.

Houve, sobretudo, uma transformação no modo de criar os filhos. Segundo Kataoka $(2008)^{205}$, cerca de $80 \%$ dos pais consideram que "atendeu na medida do possível a vontade dos filhos", na criação. Isso mostra que a tônica da criação dos pais atuais é a de dar liberdade aos filhos, embora 70\% tenham dito, também, que "foram rigorosos ao ensinar os usos e costumes diários" (ibid.).

Uma das expressões do maior envolvimento dos pais pode ser a participação na educação. Atualmente, as pesquisas indicam que uma grande parcela da população japonesa possui a opinião de que a família, entenda-se os pais, deve ser o principal responsável pela educação dos filhos, mais do que a própria escola. Isso indica uma transformação profunda, visto que, numa pesquisa realizada pela NHK, em 1962, cerca de $30 \%$ dos pais responderam que a família é a principal responsável pela educação dos filhos, $20 \%$ responderam que a escola seria responsável, e $40 \%$ responderam que ambos eram importantes. Essa tendência começa a se alterar em 1970, registrando 60\%, 10\% e 10\%, respectivamente (Mochizuki; Harimoto; Okamyo, 2010: 156), e segundo Kataoka,

\footnotetext{
${ }^{203}$ Segundo os dados de 2005, a taxa de famílias nucleares do Japão é de 57,9\% (Mochizuki; Harimoto; Okamyo, 2010: 157).

${ }^{204}$ Não nessa ordem necessariamente, mas a ideia é que estão relacionados.

${ }^{205}$ KATAOKA, Emi. Kodomo no Shitsuke Ikuji Senryaku no Shakaigakuteki Kenkyû-Kaisôsei Kôkyôsei Puraivataizêshon (Estudo Sociológico da Estratégia de Criação e Educação dos Filhos: estratificação, caráter público e privatização). Relatório de Pesquisa: Bolsa de Pesquisa 2005-2007. Tóquio: 2008. Apud Mochizuki; Harimoto; Okamyo, 2010: 159.
} 
atualmente, mais de $70 \%$ dos pais pensam ser a família a responsável pela educação dos filhos (ibid.).

Esse resultado sugere que ao reconhecer a própria responsabilidade na educação dos filhos, os pais tenham investido mais recursos e tempo na criação deles. Não obstante, na atualidade, a figura paterna é tida como ausente no lar. Embora cada vez mais se exija e muitas pesquisas apontem para a opinião majoritária de que o pai deve participar da criação dos filhos, apenas $1 \%$ dos pais tira a licença paternidade, e a média de tempo que o pai dedica na criação de filho é de 20 minutos/dia, um dos mais baixos do planeta (Yazawa e Tendo, 2004: 85). Segundo o estudo "Pesquisa Comparativa Internacional sobre Educação no Lar 2004-2005”, numa comparação com a Coréia do Sul, a Tailândia, os Estados Unidos, a França e a Suécia, o Japão é o país que apresenta o segundo menor tempo de contato entre o pai e filho(a), ficando atrás apenas da Coreia do Sul (Iwai e Kondo, 2010: 133) ${ }^{206}$. É presumível que essa realidade também afete o estabelecimento de algum vínculo afetivo entre o pai e o filho, seja de respeito ou obediência, valores estes que são cultivados no contato direto e no convívio do dia a dia. Como pode se verificar, a família contemporânea passou e passa por transformações profundas, seja na sua estrutura, seja no significado para seus membros, seja como instituição de transmissão de valores ${ }^{207}$. Essa instabilidade é interpretada, por

\footnotetext{
${ }^{206}$ Isso pode ser reflexo da característica do local de trabalho do Japão, que requer uma dedicação peculiar, como será verificado adiante.

${ }^{207}$ Por exemplo, combinando os fatores de composição familiar e identidade familiar ("quem considera membro da família"), Ueno classificou quatro tipos de família contemporânea japonesa. O primeiro tipo, composição tradicional-identidade tradicional, é a família tida como padrão, em que os membros se consideram familiares e fazem parte do mesmo domicílio. No segundo tipo da composição tradicionalidentidade não tradicional, é o caso da família que mantém a aparência ocupando o mesmo domicílio, embora seus membros tenham perdido a identidade familiar. $O$ terceiro tipo, composição não tradicional-identidade tradicional, é o caso em que um ou mais membros da família precisa residir fora, seja por necessidade profissional, doença ou conveniência. Por fim, o quarto tipo, o de composição não tradicional-identidade não tradicional, comporta os casos em que as pessoas residem no mesmo domicílio sem contrair matrimônio, casal de homossexuais, pessoas que consideram o animal de estimação como familiar, etc. (Ueno, 1994: 6-37).
} 
muitos analistas, como uma crise do modelo tradicional de família (Yamada, 2005; Iwakami, 2010).

No novo milênio, os analistas vislumbram um modelo de família em que seus membros compartilham direitos iguais e há um acordo de convívio (Nonoyama, 2009), princípios estes que devem prevalecer sobre a supremacia do casal ou ordenamento pela ordem de nascimento, e até uma relação que envolve a celebração de um contrato de convívio, estabelecendo-se direitos e deveres dos familiares (Aruka, 2004). Seja qual for o desfecho do modelo de família da nova era, indubitavelmente será algo diferente da hierarquização e preponderância de um membro sobre os outros.

6.2.3- Análise do resultado da pesquisa de campo

Na nossa amostragem, o resultado indica que a família ainda é considerada uma instituição na qual prevalece a hierarquia. Cerca de 59\% dos informantes responderam "sim" à pergunta "Você acha que existe hierarquia na família?" (cf. 8.3 do anexo):

Tabela 7: Distribuição das respostas para a pergunta se existe hierarquia na família

\begin{tabular}{cccccc}
\hline & Sim & Não & Não sabe & s/inf. & Total \\
\hline No. & 48 & 26 & 4 & 3 & 81 \\
$\%$ & 59,3 & 32,1 & 4,9 & 3,7 & 100 \\
\hline
\end{tabular}

Entretanto, essa hierarquia é sentida mais na relação pais-filhos, do que entre o casal. No item "Você acha que existe hierarquia no casal?", 63\% responderam "não": 
Tabela 8: Distribuição das respostas para a pergunta se existe hierarquia no casal

\begin{tabular}{cccccc}
\hline & Sim & Não & Não sabe & s/inf. & Total \\
\hline No. & 24 & 51 & 5 & 1 & 81 \\
$\%$ & 29,6 & 63,0 & 6,1 & 1,2 & 100 \\
\hline
\end{tabular}

Entre os que responderam "sim" à pergunta anterior, é ilustrativo que cerca de $83 \%$ tenham respondido que o marido é superior à mulher (cf. 8.4), o que faz que se revele um resíduo do pensamento patriarcalista ${ }^{208}$ :

Tabela 9: Distribuição das respostas para a pergunta quem considera superior, marido ou mulher, entre os informantes que responderam que existe hierarquia no casal

\begin{tabular}{ccccccc}
\hline & marido & mulher & nenhum & não sabe & s/inf. & Total \\
\hline No. & 20 & 4 & 0 & 0 & 0 & 24 \\
$\%$ & 83,3 & 16,7 & 0 & 0 & 0 & 100 \\
\hline
\end{tabular}

Embora minoritários, é ilustrativo o argumento dos informantes que responderam que a mulher é superior: "porque o marido sempre trabalhou fora e não

\footnotetext{
208 Isso vai ao encontro do resultado de duas perguntas feitas sobre a superioridade masculina ou feminina, de forma mais genérica: na pergunta 8.16, "Considera que na sociedade japonesa, os homens ocupam posição superior?", a resposta foi "considero" para 33,5\% dos informantes e "considero um pouco" para $37 \%$, embora uma parcela significativa de $23,4 \%$ tenha respondido "não considero". Na pergunta 8.17, "Considera que na sociedade japonesa, as mulheres ocupam posição superior?", o resultado foi mais enfático: "não considero" obteve $74,2 \%$, enquanto as respostas "considero" e "não considero" obtiveram, respectivamente, $1,2 \%$ e $2,4 \%$.
} 
sabe lidar com os afazeres do lar", "nem onde as coisas estão guardadas"209; porque é incapaz e "sempre quem tocou o negócio foi a mulher" 210 ; "porque a nossa filosofia é essa desde sempre, nunca discutimos isso",211.

Por um lado, essas respostas fazem transparecer a diferença de gerações e modo de pensar completamente diferente, no caso da terceira informante, e por outro, o fato de que não estão discutindo em termos de status ou concepção, mas em termos de competência ou funcionalidade.

Dos que responderam que o "marido" é superior, não foi possível obter alguma declaração que significativamente indicasse a razão, exceto uma que afirmou que na região onde nasceu, "dizem que a mulher é forte, mas no fundo, é mentira"212.

Essa avaliação da superioridade do marido/pai pode também ser verificada na comparação entre os membros da família, em que o pai aparece como superior absoluto para $83,3 \%$ dos informantes (cf. 8.2):

Tabela 10: Distribuição das respostas sobre o escalonamento da superioridade na hierarquia familiar

\begin{tabular}{|c|c|c|c|c|c|c|c|}
\hline & $1^{\circ}$. & $2^{\circ}$ & $3^{\circ}$. & $4^{\circ}$. & $5^{\circ}$ & s/inf. & total \\
\hline pai & 40 & 3 & 0 & 0 & 0 & 5 & 48 \\
\hline$\%$ & 83,3 & 6,3 & 0 & 0 & 0 & 10,4 & 100 \\
\hline mãe & 10 & 30 & 0 & 0 & 0 & 8 & 48 \\
\hline$\%$ & 20,8 & 62,5 & 0 & 0 & 0 & 16,7 & 100 \\
\hline irmão mais velho & 1 & 3 & 12 & 1 & 0 & 31 & 48 \\
\hline$\%$ & 2,0 & 6,3 & 25,0 & 2,0 & 0 & 64,7 & 100 \\
\hline irmã mais velha & 1 & 2 & 6 & 8 & 0 & 31 & 48 \\
\hline$\%$ & 2,0 & 4,0 & 12,5 & 16,7 & 0 & 64,8 & 100 \\
\hline $\begin{array}{l}\text { irmão ou irmã } \\
\text { mais novo ou } \\
\text { nova }\end{array}$ & 0 & 1 & 1 & 4 & 7 & 35 & 48 \\
\hline$\%$ & 0 & 2,0 & 2,0 & 8,3 & 14,6 & 73,1 & 100 \\
\hline
\end{tabular}

${ }^{209}$ Enfermeira, 59 anos, em 29 de julho de 2011, em Tóquio.

${ }^{210}$ Cozinheiro, 42 anos, em 2 de novembro de 2011, em Ehime.

${ }^{211}$ Professora, 26 anos, em 3 de novembro de 2011, em Kochi.

${ }^{212}$ Empregada de firma (administração), 55 anos, em 13 de agosto de 2011, em Fukushima. Ela é nascida em Gunma, onde popularmente diz-se que "as mulheres mandam". 
Para efeito ilustrativo, as respostas dos que preencheram o espaço "outros" foram filha, avós e nora (ibid.):

Tabela 11: Distribuição das respostas sobre o escalonamento da superioridade na hierarquia familiar, outros parentescos

\begin{tabular}{|c|c|c|c|c|c|c|c|}
\hline & $1^{\circ}$ & $2^{\circ}$ & $3^{\circ}$. & $4^{\circ}$. & $5^{\circ}$. & s/inf. & total \\
\hline filha & 0 & 0 & 1 & 0 & 0 & 47 & 48 \\
\hline$\%$ & 0 & 0 & 2,0 & 0 & 0 & 98 & 100 \\
\hline avô & 1 & 0 & 0 & 0 & 0 & 47 & 48 \\
\hline$\%$ & 2,0 & 0 & 0 & 0 & 0 & 98 & 100 \\
\hline avó & 0 & 1 & 0 & 0 & 0 & 47 & 48 \\
\hline$\%$ & 0 & 2,0 & 0 & 0 & 0 & 98 & 100 \\
\hline nora & 0 & 0 & 1 & 0 & 0 & 47 & 48 \\
\hline$\%$ & 0 & 0 & 2,0 & 0 & 0 & 98 & 100 \\
\hline
\end{tabular}

Na nossa pesquisa, a relação hierárquica entre pais e filhos aparece superando aquela verificada entre irmãos, na pergunta comparativa "No que se refere às relações abaixo, enumere na ordem que considera a hierarquia ser forte:" (cf. 8.24 do anexo). A "Relação pais-filho" aparece na segunda posição entre as relações consideradas mais fortes, com 33,5\%, sendo que a hierarquia entre os irmãos é considerada muito baixa pelos informantes, considerada forte apenas por 3,7\%:

Tabela 12: Distribuição das respostas sobre a comparação do grau de hierarquia entre diferentes relações

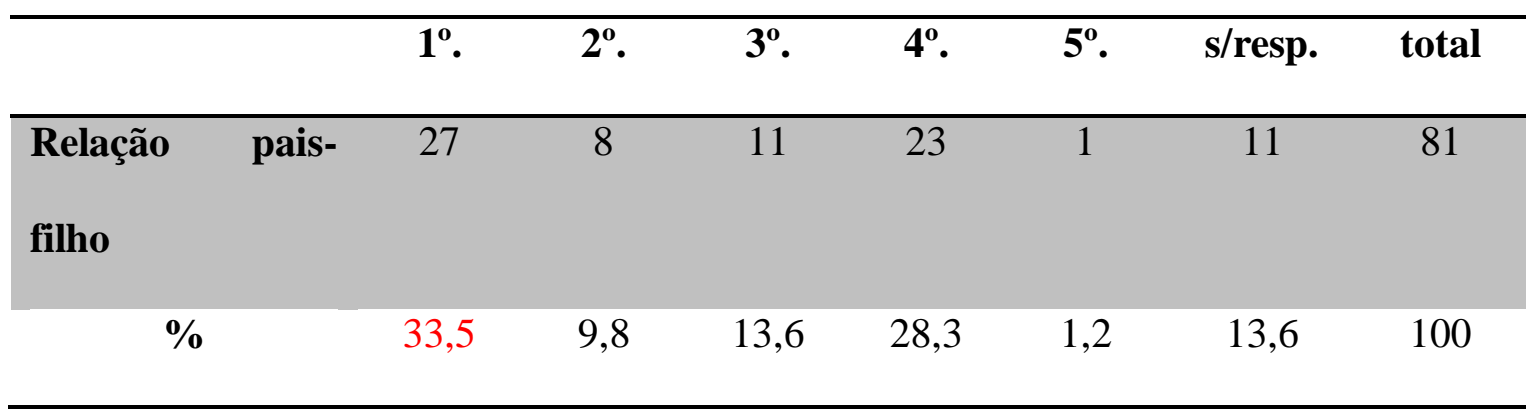




\begin{tabular}{|c|c|c|c|c|c|c|c|}
\hline $\begin{array}{l}\text { Relação entre } \\
\text { irmãos }\end{array}$ & 3 & 8 & 5 & 14 & 38 & 13 & 81 \\
\hline$\%$ & 3,7 & 9,8 & 6,2 & 17,3 & 47,0 & 16,0 & 100 \\
\hline $\begin{array}{l}\text { Relação } \\
\text { superior- } \\
\text { subordinado }\end{array}$ & 42 & 19 & 7 & 3 & 2 & 8 & 81 \\
\hline$\%$ & 52,1 & 23,4 & 8,6 & 3,7 & 2,4 & 9,8 & 100 \\
\hline $\begin{array}{l}\text { Relação senpai- } \\
\text { kôhai }\end{array}$ & 1 & 32 & 18 & 14 & 6 & 10 & 81 \\
\hline$\%$ & 1,2 & 39,6 & 22,2 & 17,3 & 7,4 & 12,3 & 100 \\
\hline $\begin{array}{l}\text { Relação mais } \\
\text { velho-mais novo }\end{array}$ & 4 & 8 & 27 & 13 & 17 & 12 & 81 \\
\hline$\%$ & 4,9 & 9,8 & 33,5 & 16,0 & 21,0 & 14,8 & 100 \\
\hline
\end{tabular}

De fato, atualmente, tudo indica que cada vez mais a hierarquia deixará de existir na relação entre os irmãos. Como afirmou uma informante que tem um filho e uma filha, que não faz distinção entre eles e não estabelece quem é superior ${ }^{213}$; outra informante diz que todas as amigas e as conhecidas também criam os filhos assim, e ainda aboliram o uso de pronomes de tratamento ${ }^{214}$ entre eles. Isso significa que esses filhos não estão sendo educados para distinguirem quem é mais velho e, com isso, o mais velho tenha tratamento diferenciado como manda a tradição, o que, ela própria, acha "um absurdo" 215 .

Essa constatação da hierarquia fraca existente entre os irmãos se reflete também no poder de pressão que os informantes sentem partindo dos irmãos mais velhos. Como mostra o quadro abaixo, apenas $13,6 \%$ responderam "sim" para a pergunta "Você considera que é impossível recusar o pedido dos irmãos mais velhos?” (cf. 8.7):

\footnotetext{
${ }^{213}$ Trabalho de meio-período, 31 anos, em 3 de novembro de 2011, em Kochi. Não por acaso, ela considera que a relação entre os irmãos é a que menos tem hierarquização.

${ }^{214} \mathrm{Na}$ língua japonesa, há pronomes para irmão mais velho e irmã mais velha, que devem ser usados no lugar de nome. Tradicionalmente, o uso de nomes para se referir ou ao dirigir aos membros mais velhos da família era considerado um erro grave, completamente fora da norma culta da língua. Em detalhes, cf. Kikuchi $(2003 ;$ 2005).
} 
Tabela 13: Distribuição das respostas para a pergunta se é impossível recusar o pedido dos irmãos mais velhos

\begin{tabular}{cccccc}
\hline & Sim & Não & Não sabe & s/inf. & Total \\
\hline No. & 11 & 46 & 12 & 12 & 81 \\
$\%$ & 13,6 & 56,8 & 14,8 & 14,8 & 100 \\
\hline
\end{tabular}

Esse quadro se altera quando indagado sobre os pais, na pergunta "Você considera que é impossível recusar o pedido dos pais?” (cf. 8.5):

Tabela 14: Distribuição das respostas para a pergunta se é impossível recusar o pedido dos pais

\begin{tabular}{cccccc}
\hline & Sim & Não & Não sabe & s/inf. & Total \\
\hline No. & 32 & 40 & 8 & 1 & 81 \\
\% & 39,6 & 49,4 & 9,8 & 1,2 & 100 \\
\hline
\end{tabular}

Percebe-se que há um maior equilíbrio, do que na pergunta sobre os irmãos. Por outro lado, é possível fazer a leitura de que a superioridade dos pais identificada na pergunta 8.24 acima não significa a ideia de que têm poder absoluto deles sobre os filhos, ou a sujeição automática dos filhos. Embora tenha prevalecido a resposta "não", a diferença é tênue em relação ao total da resposta "sim".

${ }^{215}$ Funcionária pública, 34 anos, em 24 de outubro de 2011, em Nagasaki. 
Como assuntos que dificilmente poderiam ser recusados, caso fossem solicitados pelos pais, prevaleceram, pela ordem, questões sociais (relacionamento com os parentes), questões íntimas, questões financeiras e resolução de problemas (cf. 8.6):

Tabela 15: Distribuição das respostas para a pergunta "Dos itens abaixo, quando pedido pelos pais, qual você considera difícil de recusar?", admitindo-se mais de uma resposta

\begin{tabular}{|c|c|c|c|c|}
\hline $\begin{array}{l}\text { assuntos que } \\
\text { envolvem } \\
\text { dinheiro }\end{array}$ & $\begin{array}{l}\text { consulta sobre } \\
\text { questões íntimas }\end{array}$ & $\begin{array}{l}\text { resolução de } \\
\text { problemas }\end{array}$ & $\begin{array}{l}\text { questão de relacionamento } \\
\text { com parentes etc. }\end{array}$ & outros \\
\hline 20 & 25 & 18 & 28 & 1 \\
\hline
\end{tabular}

As diferenças são mínimas, de modo que dificulta a análise. Em todo caso, prevaleceu a opção que remete para o relacionamento extrafamiliar, o que é compreensível, já que os pais normalmente representam a família, na relação com os parentes. Isso fica evidente na pergunta sobre os irmãos, na qual prevalece o item "questões íntimas", apesar de apresentar, novamente, diferença muito pequena (cf. 8.8):

Tabela 16: Distribuição das respostas para a pergunta "Dos itens abaixo, quando pedido pelos irmãos mais velhos, qual você considera difícil de recusar?", admitindo-se mais de uma resposta

\begin{tabular}{|c|c|l|c|c|}
\hline $\begin{array}{l}\text { assuntos que } \\
\text { envolvem } \\
\text { dinheiro }\end{array}$ & $\begin{array}{l}\text { consulta sobre } \\
\text { questões íntimas }\end{array}$ & $\begin{array}{l}\text { resolução de } \\
\text { problemas }\end{array}$ & $\begin{array}{l}\text { questão de relacionamento } \\
\text { com parentes etc. }\end{array}$ & outros \\
\hline 10 & 16 & 11 & 11 & 0 \\
\hline
\end{tabular}

Dessa forma, foram constatadas a percepção da existência de hierarquia na família e o fato de que isso é sentido na relação pais-filhos e não entre irmãos. 


\section{3- Escola}

A escola possui basicamente três funções na sociedade: de socialização, de seleção e de legitimação (Iwai e Kondo, 2010: 6). Ela possui a prerrogativa de orientar e selecionar em diversas carreiras e futuras posições sociais os estudantes que nela passam, além de prepará-los para o mercado de trabalho ${ }^{216}$. A escola também legitima os aspirantes a essas carreiras e posições sociais, os formados, através da emissão de diplomas e certificados. Apesar da importância dessas atribuições da escola, interessa, para o presente trabalho, a primeira função, a de socialização.

A atribuição para a escola da tarefa de socialização é clássica, e ela se apresenta na continuidade da família, como pode ser verificado no trecho seguinte, escrito por Durkheim:

Quando se observam os fatos tais como são e tais como sempre foram, salta aos olhos que toda educação consiste num esforço contínuo para impor à criança maneiras de ver, de sentir e de agir às quais ela não teria chegado espontaneamente. Desde os primeiros momentos de sua vida, forçamo-las a comer, a beber, a dormir em horários regulares, forçamo-las à limpeza, à calma, à obediência; mais tarde, forçamo-las para que aprendam a levar em conta outrem, a respeitar os costumes, as conveniências, forçamolas ao trabalho, etc., etc. Se, com o tempo, essa coerção cessa de ser sentida, é que pouco a pouco ela dá origem a hábitos, a tendências internas que a tornam inútil, mas que só a substituem pelo fato de derivarem dela. É verdade que, segundo Spencer, uma educação racional deveria reprovar tais procedimentos e deixar a criança proceder com toda a liberdade; mas como essa teoria pedagógica jamais foi praticada por qualquer

\footnotetext{
${ }^{216}$ Obviamente, esse debate envolve questões como meritocracia e igualdade de oportunidade de estudo, de acesso à educação. Discussão dessa natureza encontra-se em Bourdieu (2008), entre outros.
} 
povo conhecido, ela constitui apenas um desideratum pessoal, não um fato que se possa opor aos fatos que precedem. Ora, o que torna estes últimos particularmente instrutivos é que a educação tem justamente por objetivo produzir o ser social; pode-se portanto ver nela, como que resumidamente, de que maneira esse ser constituiu-se na história. Essa pressão de todos os instantes que sofre a criança é a pressão mesma do meio social que tende a modelá-la à sua imagem e do qual os pais e os mestres não são senão os representantes e os intermediários. (Durkheim, ARMS, 1999: 6)

Dessa forma, para Durkheim, educar é produzir o ser social e, nesse sentido, é inegável que a escola, ao lado da família, constitui um aparato de transmissão de valores, no sentido de passar às gerações seguintes os valores e costumes de uma determinada geração de uma dada sociedade, considerados importantes para a reprodução social, para a própria continuidade da sociedade.

A escola, pela sua natureza, pressupõe hierarquia interna. Há sempre uma desigualdade de posição entre aquele que ensina (mestre) e aquele que aprende (aprendiz). Mas afora a conscientização dessa hierarquia básica, haveria alguma outra forma de transmitir, de compelir os aprendizes a internalizem a noção de hierarquia nas escolas japonesas? Para discutir essa questão, é necessário voltar para o passado.

\subsection{1- Um breve histórico da escola no Japão}

As instituições de ensino do Japão tal qual conhecemos hoje surgiram juntamente com o Estado moderno, no final do século XIX.

Historicamente, é possível garimpar no registro histórico algumas instituições de formação que podem ser consideradas embriões de escolas. No século IX, por volta de 
828, teria surgido em Quioto uma instituição que pode ser considerada pioneira na educação, com o objetivo de ensinar principalmente o budismo e o confucionismo ${ }^{217}$. Os templos budistas Enryakuji, de $\operatorname{Hieizan}^{218}$, e Kongôbuji, de Kôyasan ${ }^{219}$, sempre mantiveram uma estrutura de formação de monges. Os nobres também valorizaram a formação nas artes, e os samurais, que tomaram o poder no final do século XII, cultivaram a educação e a formação como guerreiro dentro de suas casas. Como instituição educacional criada pelos guerreiros, destaca-se o Ashikaga Gakkô, fundada por volta de $1432^{220}$. Mas foi no período Tokugawa, quando se instaurou a paz após o período de guerras, que ocorreu uma notável expansão das escolas denominadas hankô (hangaku) nos territórios [han]. No final do século XVIII, praticamente todos os territórios possuíam suas escolas.

Como se pode observar, por um longo período, a educação era privilégio de monges, nobres, guerreiros e uma pequena parcela de comerciantes, mas no início do século XIX, estendeu-se para a população em geral, por meio das escolas particulares denominadas terakoya, onde as crianças de seis a treze anos aprendiam a ler, a escrever, a manipular o ábaco, além de obter conhecimentos para a vida e princípios morais baseados principalmente no confucionismo. No final do século XIX, estima-se que havia cerca de 15 mil estabelecimentos de terakoya em todo o arquipélago, e que cerca de $20 \%$ da população comum (citadinos e camponeses) haviam estudado nessa instituição, mostrando alto grau de alfabetização para o período, mesmo comparado com outros países ocidentais (Mochizuki, Harimoto e Okamyo, 2010: 49).

\footnotetext{
${ }^{217}$ Denominado Shugeishuchiin, foi fundado pelo monge Kûkai (774-835). Cf. Takagi, 2009.

${ }^{218}$ Situa-se na província de Shiga, é o templo-matriz da corrente Tendai, do budismo.

${ }^{219}$ É o templo-matriz da corrente Shingonshû, fica na província de Wakayama.

${ }^{220} \mathrm{Na}$ época, era considerada instituição superior de estudos sobre budismo e confucionismo onde monges e samurais de todo o arquipélago se reuniam para se instruir. Situava-se na atual província de Tochigi, e existiu até o ano de 1872. Cf. Kawase, 1974.
} 
Em 1872, portanto, já no período Meiji, foi instituído o Gakusei, "Sistema Educacional", que reconheceu o direito de todas as crianças, independentemente de origem social, de terem acesso à educação. Entretanto, principalmente as dificuldades de ordem econômica impediam o acesso de filhos de origem mais humilde ${ }^{221}$, e a taxa de frequência escolar somente foi crescer a partir de 1890, quando é publicada a "Mensagem Imperial sobre a Educação" [kyôikuchokugo], estabelecendo as diretrizes da educação do Império Japonês. O conteúdo dessa Mensagem é ilustrativo para a compreensão da educação na fase anterior à guerra e será objeto de atenção do próximo tópico.

\subsubsection{1- A escola do Império Japonês}

Em vigor a partir de 1890, a "Mensagem Imperial sobre a Educação" estabeleceu que a base da educação do Japão seria o império, formado pela lealdade do povo ao imperador, que representa a virtude da nação, e traz doze ensinamentos que devem ser seguidos, incluindo entre outros a devoção aos pais e a harmonia entre os irmãos. Afirmava, ainda, que por necessidade da nação, o japonês teria que oferecer o “corpo e a alma" quando convocado pelo império. É nessa fase que se inicia a distribuição da fotografia do imperador e imperatriz Meiji [goshin'ei] para as escolas, sendo que, na década de 1930, todas as instituições de ensino do país possuíam tal imagem nas suas dependências (Hirooka, 2007: 135) ${ }^{222}$.

\footnotetext{
${ }^{221}$ Além da dificuldade financeira, para muitos pais, os filhos eram mãos-de-obra importantes para o sustento, e não permitiam que eles frequentassem a escola. Para obrigá-los a liberar os filhos, algumas autoridades até recorriam à força policial (Narusawa, 2011: 112).

${ }^{222}$ Cf. Capítulo 4, seção 4.5.
} 
Um componente instrumental-metodológico importante dessa "doutrinação" era a introdução dos princípios de treinamento militar na educação. Na escola de formação de professores [shihan gakkô] reorganizada em 1886, num regime de internato inspirado na academia militar, rigorosas normas de convívio em grupo e a obrigação de treinamento físico foram implantadas, para que os alunos assimilassem e, na condição de professores formados, as aplicassem cada qual na sua escola (Narusawa, 2011: 115). Como componente desse "treinamento", o castigo físico era constante. Embora fosse proibido, por lei, em 1879, punir os alunos com castigo físico foi uma regra constante nesse período (op.cit.: 116). A própria direção da escola tinha fortes vínculos com o setor militar. Segundo Wolferen, a maioria dos diretores da escola primária era militar reformado (1999: 217).

Verifica-se, assim, que a escola desse período tinha orientação fortemente ideológica, exercendo o papel de formação dos súditos leais ao império. Essa tendência se fortalece a partir da ascensão dos militares ao governo e a eclosão da Guerra do Pacífico em 1941. Foi neste ano que foi instaurada a chamada "escola do povo" [kokumingakkô] em substituição à escola do primeiro ciclo [shogakkô], pela promulgação da kokumingakkôrei ("Lei da Escola do Povo"), cujo artigo primeiro estabelecia o objetivo da escola de "realizar a educação e formação básica do povo seguindo as diretrizes do império" (Hirooka, op.cit.: 152). O currículo dessa escola era dividido em ciclo inicial, de seis anos, e superior, de dois anos, totalizando oito anos de ensino obrigatório.

A convocação dos estudantes para trabalhar nas fábricas de confecção de armamentos e outros insumos de guerra começou em 1938, e a partir de 1941, até 30 dias letivos eram convertidos para tal finalidade. A partir de 1943, estudantes masculinos acima de vinte anos foram convocados para a guerra. 
A partir de abril de 1945, todas as aulas, com exceção do ciclo inicial, foram suspensas, mas o intenso bombardeio dos americanos já havia inviabilizado qualquer atividade de ensino. Após a rendição do Japão, em setembro, sob a ocupação dos aliados, o gabinete formado por Higashikuninomiya Naruhiko decretou a retomada das aulas, duas semanas após o término da guerra (Hirooka, op.cit.: 156).

\subsubsection{2- Nova educação no pós-guerra}

Em 1947, a "Mensagem Imperial sobre a Educação" é abolido e entra em vigor a Lei Orgânica da Educação [kyôiku kihon'hô] e a Lei da Educação Escolar [gakkô kyôikuhô], que universaliza o ensino no Japão. Foi instituído o chamado "sistema 6-3-34", ou seja, seis anos no primeiro ciclo [shôgakkô] (primário; ensino básico); três anos no segundo ciclo [chûggakkô] (ginásio; ensino fundamental); três anos no terceiro ciclo [kôtôgakkô] (ensino médio) e quatro anos no ensino superior [daigaku]. Uma das características desse sistema é que nos dois primeiros ciclos, não há reprovação. Isso faz com que todas as séries e classes escolares desses ciclos sejam constituídas por alunos de mesma idade ${ }^{223}$, e todas as atividades escolares são organizadas tendo como princípio esse escalonamento por idade (Mochizuki, et al., 2010: 60).

Como que tentando abolir todos os resquícios da educação da fase anterior, a nova diretriz de ensino, elaborada sob a supervisão dos americanos, enfatizava a importância de se ensinar os "princípios democráticos", os direitos humanos, a cidadania, a consciência da individualidade, direitos e deveres, e tudo o que inspirava

\footnotetext{
${ }^{223}$ É necessário lembrar que o ano letivo japonês se inicia em abril e termina em março do ano seguinte. Todas as crianças que completam sete anos naquele ano letivo devem se matricular em abril, portanto, as crianças que nasceram nos meses de janeiro a março são incorporadas na série do ano anterior.
} 
militarismo e imperialismo foi expurgado. Nesse contexto, a educação que enfatizava a hierarquia, fidelidade e obrigação, típica da fase imperial, foi condenada (Hirooka, op.cit.: 157).

Além dos dois primeiros ciclos [shogakkô e chugakkô], que são obrigatórios, atualmente, 97,8\% dos estudantes ingressam no terceiro ciclo do sistema educacional japonês ${ }^{224}$ [kôtôgakkô] (Tsuchiya, 2011: 74). Isso evidencia a importância da escola na formação dos jovens, contando ainda que no Japão a escola é de período integral, não existindo turnos como ocorre no Brasil.

\subsection{2- A escola e a consciência hierárquica}

A julgar pelas breves considerações acima feitas sobre a escola do Japão, esperava-se que a escola fosse apontada como uma instituição fomentadora de igualdade e não de relação hierárquica. Mas contrariando essa expectativa, muitos informantes mencionaram a escola como o local onde adquiriram a noção de hierarquia, ou a fase estudantil como aquela em que a consciência hierárquica foi despertada.

Uma possível explicação está no fato de que a escola japonesa exerce sobre seus alunos um rigoroso controle de conduta, tarefa esta que é atribuída pela própria sociedade. Mesmo estando nos domínios fora da escola, o aluno é sempre relacionado com a escola ${ }^{225}$. Como anteriormente mencionado, o aluno permanece quase o dia inteiro na escola, almoça aí, faz a faxina e ainda participa das atividades

\footnotetext{
${ }^{224}$ A taxa de ingresso no ensino superior é de 52,9\% (Tsuchiya, 2011: 75).

${ }^{225}$ Por exemplo, algo muito comum atualmente no Japão, quando um aluno comete suicídio, é o diretor da escola onde ele frequentava que aparece nos meios de comunicação para dar satisfação e, muitas vezes, dele é cobrada alguma responsabilidade.
} 
extracurriculares $^{226}$. Todos os alunos são uniformizados, e a escola possui regulamentos que determinam o tipo do corte de cabelo, os adereços que podem ser usados, o comprimento da saia que as alunas podem vestir, medido a partir do joelho, algumas escolas proíbem que seus alunos venham de bicicleta, etc ${ }^{227}$. Então, não é por acaso que a existência de todas essas regras, detalhadas, faça recordar o militarismo implantado nas escolas japonesas na fase anterior à guerra. Talvez tenha mudado a feição e a filosofia oficial, mas o princípio continua o mesmo. Não por acaso, todas as escolas japonesas têm o seu hino e a sua bandeira. Mesmo o castigo físico ainda é presente nas escolas japonesas, muito mais do que imaginamos ou que as estatísticas demonstram ${ }^{228}$.

Nas escolas, ainda precisamos considerar a relação "veteranos" e "novatos". Como essa discussão está imbricada com a da dimensão temporal, assunto do próximo e último capítulo, será reservada para esse espaço, que consideramos mais adequado.

\section{4- Empresa}

É possível afirmar que a empresa é um dos protótipos da instituição burocratizada, onde, a despeito da diversidade na área de atuação, da variedade de formatos e estilos no que se refere à organização, e da inovação na gestão administrativa, ainda impera, em maior ou menor grau, a dominação burocrática tal qual concebida por Weber.

\footnotetext{
${ }^{226}$ Sobre esse assunto, será discutido no próximo capítulo.

${ }^{227}$ Por exemplo, no regulamento do colégio Kokugakuin, um dos mais tradicionais de Tóquio, consta que os alunos são "inspecionados" mensalmente no pátio da escola, e proíbe, entre outros, tingir o cabelo, usar um cinto que não seja de cor preta, usar uma saia que descubra os joelhos, usar o brinco, etc. Em http://softly.s54.xrea.com/kousoku.html, acessado em 22 de janeiro de 2012.

${ }^{228}$ Cf. Totsuka (2006) e Ogi (2006).
} 
Como uma das características da estrutura burocrática, Weber menciona a hierarquia interna organizada em instâncias, em que o inferior é fiscalizado pelo superior (1999: 199).

Dessa forma, a hierarquização da empresa é inerente à sua estrutura organizacional, sendo que o objetivo primeiro e principal de uma empresa é obter lucro, e a racionalização é um dos pressupostos para se alcançar esse objetivo.

Como produto da industrialização e da evolução do capitalismo, as empresas japonesas não são diferentes das empresas ocidentais na sua essência, mas ancoradas no sucesso econômico, dos anos 1960 a início dos anos 70, e na relativa estabilidade até os anos 80, vários aspectos da especificidade das companhias japonesas foram destacados como fatores de seu êxito.

Para o propósito de análise, a discussão será dividida em duas fases: década de 1960 a 1980, e década de 90 aos dias atuais.

6.4.1- Década de 1960 a 80: expansão econômica e peculiaridades da empresa japonesa

Dos estudos sobre a empresa japonesa dessa época, do ponto de vista de sua organização e estabelecimento da hierarquia, dois aspectos merecem destaque ${ }^{229}$. São eles a "contratação vitalícia", "escalonamento pela idade e tempo de serviço", fatores estes vinculados, e a "empresa como família", que serão explanados a seguir.

\footnotetext{
${ }^{229}$ Os analistas apontam, além da "contratação pela vida inteira" e "escalonamento pela idade e tempo de serviço", o terceiro fator, que seria o sindicato organizado em cada empresa e não pela categoria (Mori, 2004: 136) , mas esse fator não será aqui tratado por estar fora do nosso objetivo de estudo.
} 


\subsubsection{1 - "Contratação vitalícia", idade e tempo de serviço}

Em primeiro lugar, é necessário destacar a concepção de "contratação vitalícia" [shûshinkoyô ${ }^{230}$, em que o recém-formado é contratado pela empresa, treinado e reeducado nos moldes que a servem, ali faz carreira e se aposenta ${ }^{231}$. Nesse caso, os recém-formados são contratados "por atacado", ou seja, diversos funcionários novos são contratados no mesmo ano, com mesma idade, formando uma "geração" nova, de fato, na mesma empresa ${ }^{232}$.

Em segundo lugar, existe o "escalonamento pela idade e tempo de serviço" [nenkôjoretsu] que, como o próprio nome diz, consiste em princípio de hierarquização pela idade e tempo de serviço na empresa ${ }^{233}$. Como há gerações de funcionários contratados no mesmo ano na empresa, conforme descrito acima, na prática constitui um mesmo critério, já que normalmente o indivíduo ingressa na mesma empresa com os pares da mesma idade. Até os anos 1990, esse princípio era referência para promoção em praticamente todas as empresas, sendo que dificilmente um funcionário que tivesse

\footnotetext{
${ }^{230}$ É ilustrativo observar que Abegglen, um dos primeiros a analisar a empresa japonesa, caracterizou esse relacionamento entre a empresa e funcionários como "compromisso pelo tempo de vida" (lifetime commitment), destacando o caráter fraternal que prevalecia (1984: 11 e ss).

${ }^{231}$ Nesse contexto, trocar de empresa ou mesmo de ramo de atividade contava negativamente no currículo (Makino, 2006: 198).

${ }^{232}$ Esse fator cria a relação entre os "veteranos" e "novatos", como será examinado no Capítulo 7.

${ }^{233} \mathrm{O}$ nenkôjoretsu é um princípio que é adotado não somente nas empresas, mas em outras áreas da sociedade japonesa. Por exemplo, o Dragons, time profissional de baseball do Japão, que veio se consagrar campeão da Liga Central no final do ano de 2011, anunciou em setembro, início da reta final do campeonato, que seu técnico seria substituído no final da temporada por um septuagenário, quase quinze anos mais velho. Já no oitavo ano no comando do time, esse técnico já foi campeão da Liga três vezes e campeão nacional uma vez, sendo que nos demais anos sempre disputou até o fim o título. Para Jô Shigeyuki, analista de gestão pessoal, pesou contra o técnico o fato de trazer auxiliares externos, que não foram jogadores do Dragons, e prevaleceu o princípio de nenkôjoretsu, como afirma: "Quase todas as organizações do Japão são administradas tendo como base o princípio de nenkôjoretsu. Os gerentes ou chefes de departamento [buchô] são na maioria os veteranos com mais de vinte anos de casa, o presidente é aquele que está há trinta anos na empresa. Se trouxer alguém de fora para esses cargos [...], o departamento de pessoal sofre uma pressão insuportável. A causa última dessa substituição do técnico também pode ser analisado sob mesmo ângulo. [...] A individualidade foi derrotada pela "lei da aldeia"" (artigo "Estilo Individual vs Sociedade de Aldeia", revista semanal Spa!, ed. 11 de outubro de 2011, p. 143. ). Há que se ponderar que algo semelhante pode acontecer no Brasil, num time profissional de
} 
ingressado posteriormente fosse nomeado no cargo de chefia ultrapassando aquele que ingressara antes na empresa, independentemente de seu desempenho profissional, mantendo a prática consolidada nos anos 60 (Nakane: 1967). Ou seja, existia uma "fila" para promoção, e o critério era aparentemente "objetivo", como argumentam seus defensores, ou seja, o fator tempo, incontestável e inalterável.

\subsubsection{2- A empresa como "família"}

Vários autores destacam que a hierarquização e o tipo de dominação verificados nos locais de trabalho possuem uma estrutura análoga à da casa (Mito, 1994) ou que simplesmente trata-se de uma forma evoluída, onde, na esteira da industrialização, quando a atividade econômica passou a ser desenvolvida num local distante do ambiente doméstico, o esquema até então vigente nos lares foi transplantado para as empresas (Terasawa, 2000: 174).

Por exemplo, nas empresas japonesas, as mesas são juntadas e colocadas numa disposição em que na cabeceira senta-se o superior hierárquico, voltado para todos, e os demais sentam um de frente ao outro, numa ordenação que parte dos "veteranos", acomodados próximo do chefe, e vai até o mais novato, cuja mesa é a mais distante, numa gradação que representa a ordem de ingresso. Mesmo quando há uma sala reservada para o chefe, os subordinados costumam ter acesso quase que irrestrito para trabalhar, ao contrário das empresas ocidentais que asseguram a privacidade do superior.

Mais um exemplo da analogia com a casa seria o vocabulário empregado nas empresas. Os japoneses empregam o termo uchi ("minha casa", "meu lar") para se 
referirem ao próprio local de trabalho, como empresas e outras instituições, e uchi no mono ("gente de minha casa", "membro de meu lar") para se referir aos colegas de trabalho, mencionando-os em conversas com alguém "de fora", clientes, funcionário de outras empresas etc.

Muitos autores destacam o aspecto positivo da empresa como casa. Para Mori, a consciência da empresa como "família" criou a identificação do trabalhador com a empresa onde trabalha, aumentou a produtividade e tornou-se a força motriz do milagre econômico japonês do pós-guerra ${ }^{234}$ (2004:39).

6.4.2- Alteração na relação de trabalho: década de 1990 a dias atuais

Após o chamado estouro da bolha financeira em 1991, a economia japonesa mergulhou na fase de crise e estagnação, e ao longo da década, as empresas japonesas são obrigadas a alterar a sua estrutura empresarial e o seu modelo de gestão ${ }^{235}$.

Como sintoma disso, em 1995, a Federação de Associações de Administradores do Japão (Nikkeiren) divulgou um relatório apresentando as diretrizes da nova era de dificuldades econômicas. Nele são defendidas as medidas como atenuação da “contratação vitalícia" e do "escalonamento pela idade e tempo de serviço" (1995: 30-

princípio da ordem de ingresso no meio.

${ }^{234}$ É interessante observar que a palavra shain, empregada para designar os funcionários de empresa, pode significar, também, juridicamente, acionista de companhia limitada. Existe a palavra jûgyôin, que pode também ser traduzida como funcionário, mas ela é empregada para designar atendente de loja ou, mesmo nas empresas, os funcionários não efetivos. Os funcionários efetivos são shain ou seishain, este último ressaltando a efetivação. Dessa forma, a palavra que significa acionista, em outras palavras, investidor, sócio da empresa, é empregada também para o funcionário, e retrata bem o pensamento de envolver o trabalhador ao destino da empresa. Esse uso teria começado nos meados da década de 1960, ou seja, no auge do milagre econômico japonês (Mori, 2004: 38).

${ }^{235} \mathrm{Em} \mathrm{1997,} \mathrm{uma} \mathrm{grande} \mathrm{corretora} \mathrm{e} \mathrm{um} \mathrm{banco} \mathrm{público} \mathrm{faliram,} \mathrm{houve} \mathrm{demissão} \mathrm{em} \mathrm{massa} \mathrm{nas} \mathrm{grandes}$ empresas, os recém-formados deixaram de ter garantia de emprego automático. Diante dessa 
34), além da implantação da flexibilidade das relações de trabalho e a diminuição das garantias trabalhistas, com o intuito de aumentar a eficiência e valorizar a capacidade individual dos funcionários (1995: 48-51).

Do final da década de 90 ao início do novo século, as empresas japonesas, na sua maioria de grande porte, introduziram o sistema de promoção que avalia o desempenho pessoal, ou seja, a meritocracia passou a ser regra no lugar do critério de tempo de trabalho. De acordo com a "Pesquisa Geral de Condições de Trabalho" do Ministério do Trabalho e Seguridade Social, em 2001, as companhias que introduziram a produtividade e o desempenho como critério para o estabelecimento do salário-base dos cargos de chefia atingiu 62,3\% $\%^{236}$ (Hattori, 2011: 5). Segundo Morishima $\left(1996^{237}\right.$ ), em 1994, das 1628 empresas pesquisadas ${ }^{238}, 919$ (56,4\%) adotavam o "critério de tempo de serviço" e a "garantia de emprego por longo período", mas em 2004, das 1207 empresas pesquisadas, somente $489(40,5 \%)$ havia respondido que adotavam esses critérios $^{239}$. Outros autores afirmam que a economia deflacionária obriga as empresas a cortar custos, cortando funcionários efetivos e terceirizando as atividades (Wakabayashi, 2009: 134; Mori, 2004: 157 e ss). Assim, na teoria, o ciclo de um funcionário na empresa passa ser curto; o que até então tinha a duração pela carreira toda, passa a ser por contrato, ou pela duração de um projeto.

realidade, um alto executivo de um conglomerado japonês chegou a afirmar que "o antigo regime do meio empresarial japonês entrou em colapso em 1997" (Mori, 2004: 14).

${ }^{236}$ Foram consultadas 5300 empresas privadas com mais de 30 funcionários efetivados, de dez áreas: mineração; construção; manufaturados; eletricidade, gás, energia e encanamentos; transportes e telecomunicação; finanças e seguros; atacadista e varejista; alimentação; imobiliária; serviços.

${ }^{237}$ MORISHIMA, M., The Evolution of White-collar Human Resource Management in Japan. In: Lewin, D. Kaufman, B.E. ; Sockell, D. (org). Advances in Industrial and Labor Relations. Vol. 7, p. 145-176. Greenwich, Conn: JAI Press Inc., 1996. Apud Hattori, 2011: 6.

${ }^{238}$ Empresas do ramo de serviços e manufaturados.

${ }^{239}$ MORISHIMA, M., Howaitokarâ Jinzai Manêjimento no Shinka - Hatashite Seikashugi wa Chôkikoyô to tekigôtekina Shisutemu nanoka (Evolução da Gestão de White-collar: a ênfase no resultado é compatível com o emprego duradouro?). In : ITAMI, H. et al. Ridingusu Nihon no Kigyô Shisutemu. P. 269-303. Fase II, vol. 4. Tóquio: Yuhikaku, 2006. Apud Hattori, 2011: 6. 
Não obstante, a mesma pesquisa de 2004 mostra que, apesar da redução, o "critério de tempo de serviço" e a "garantia de emprego por longo período" (489 $(40,5 \%)$ ) ainda continuam liderando como referência das empresas, superando as 456 empresas $(37,81 \%)$ que adotam a avaliação baseada na produtividade, sem abandonar a "garantia de emprego por longo período" ${ }^{240}$. Takahashi afirma que a implantação do modelo de avaliação por produtividade nas empresas japonesas não tem tido êxito satisfatório (2004). Numa publicação recente, outro autor homônimo afirma que a falta de comprometimento dos funcionários com a empresa, resultado da terceirização, e a pressão excessiva sobre o funcionário por resultados têm esgarçado o relacionamento nos locais de trabalho (Takahashi, 2008). Yamashita (2010), por sua vez, defende a tese de que a garantia de emprego por longo período criou o sentimento de pertencimento dos funcionários às empresas, criando um comprometimento à sua causa, e que isso foi o fator primordial para o aumento da qualidade dos produtos japoneses (Yamaguchi, 2010).

Verifica-se, assim, que há muitas divergências no que se refere ao grau de consolidação do novo sistema de avaliação, valorização e promoção de funcionários, o que no fundo, hierarquiza-os, nem quanto ao êxito dessas reformas.

\footnotetext{
${ }^{240}$ MORISHIMA, M., ibid.
} 
6.4.3- A empresa e a consciência hierárquica

Diante desse quadro, veremos o resultado da nossa amostragem sobre consciência hierárquica nas empresas. Para a maioria, a empresa continua sendo o lugar onde mais se verifica a hierarquização.

Na pergunta 8.24, a "relação superior-subordinado", por definição, relação típica do local de trabalho, teve maior menção como "hierarquia forte", cerca de 52\%:

Tabela 17: Distribuição das respostas sobre a comparação do grau de hierarquia entre diferentes relações

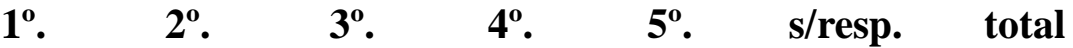

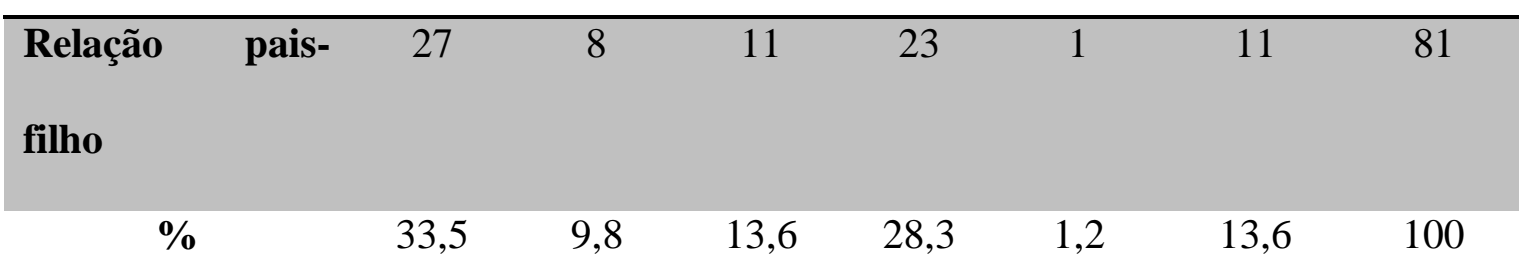

\begin{tabular}{ccccccccc|}
$\begin{array}{l}\text { Relação } \\
\text { irmãos }\end{array}$ & entre & 3 & 8 & 5 & 14 & 38 & 13 & 81 \\
$\%$ & & 3,7 & 9,8 & 6,2 & 17,3 & 47,0 & 16,0 & 100
\end{tabular}

$\begin{array}{cccccccc}\begin{array}{l}\text { Relação } \\ \text { superior- } \\ \text { Subordinado }\end{array} & 42 & 19 & 7 & 3 & 2 & 8 & 81 \\ \quad \% & 52,1 & 23,4 & 8,6 & 3,7 & 2,4 & 9,8 & 100\end{array}$

\begin{tabular}{cccccccc}
$\begin{array}{l}\text { Relação senpai- } \\
\text { kôhai }\end{array}$ & 1 & 32 & 18 & 14 & 6 & 10 & 81 \\
\multicolumn{1}{c}{$\%$} & 1,2 & 39,6 & 22,2 & 17,3 & 7,4 & 12,3 & 100 \\
$\begin{array}{l}\text { Relação mais } \\
\text { velho-mais novo }\end{array}$ & 4 & 8 & 27 & 13 & 17 & 12 & 81 \\
$\quad$ \% & 4,9 & 9,8 & 33,5 & 16,0 & 21,0 & 14,8 & 100 \\
\hline
\end{tabular}


Por outro lado, a relação superior-subordinado não significa sujeição automática por parte do mais fraco, face ao resultado de que $66,7 \%$ responderam não à pergunta "Você considera que é impossível recusar o pedido do superior de trabalho?" (cf.8.9):

Tabela 18: Distribuição das respostas para a pergunta se é impossível recusar o pedido do superior de trabalho

\begin{tabular}{cccccc}
\hline & Sim & Não & Não sabe & s/inf. & Total \\
\hline No. & 12 & 54 & 14 & 1 & 81 \\
$\%$ & 14,8 & 66,7 & 17,3 & 1,2 & 100 \\
\hline
\end{tabular}

Como que fosse previsível e óbvio, o item que os informantes consideram difícil de recusar, partindo do superior, é aquele relacionado com os assuntos de trabalho (cf. 8.10), assim como o item sobre o que pode pedir (ou já pediu) para seu subordinado (cf. 8.11):

Tabela 19: Distribuição das respostas para a pergunta "Dos itens abaixo, quando pedido pelo superior de trabalho, qual você considera difícil de recusar?", admitindo-se mais de uma resposta

\begin{tabular}{|c|c|c|c|}
\hline assuntos de trabalho & assuntos particulares & assuntos que envolvem dinheiro & outros \\
\hline 20 & 5 & 3 & 0 \\
& & & \\
\hline
\end{tabular}

Tabela 20: Distribuição das respostas para a pergunta "Dos itens abaixo, qual você, na condição de superior de trabalho, pode pedir (ou já pediu) para seu subordinado?", admitindo-se mais de uma resposta

\begin{tabular}{|c|c|c|c|}
\hline assuntos de trabalho & assuntos particulares & assuntos que envolvem dinheiro & outros \\
\hline 70 & 13 & 0 & 1 \\
& & & \\
\hline
\end{tabular}


Dessa forma, a empresa é identificada com o grau de hierarquização forte, mas se considerar apenas a relação superior-subordinado, a ascendência do primeiro sobre o segundo se limita aos assuntos de trabalho, não apresentando, aparentemente, nenhuma particularidade. Entretanto, essa relação é atravessada pela relação de ordem de ingresso na empresa, não considerada oficialmente para efeito de promoção, como era a prática, mas no relacionamento e convívio pessoal e diário. Mas isso é assunto do próximo capítulo.

\subsection{4- Considerações finais}

Ao considerar as relações hierárquicas nas três instituições japonesas tratadas neste capítulo, a família, a escola e a empresa, é necessário ressaltar o aspecto da sua inevitabilidade. Ou seja, o indivíduo japonês dificilmente consegue ficar alheio a essas relações. Na família, porque a pessoa não escolhe na qual vai nascer, e embora a tendência seja de a hierarquia estar cada vez mais ausente nela, pelo menos nas primeiras décadas, seu desenvolvimento como ser vivo e social depende dela ${ }^{241}$. No caso da escola, porque na sociedade moderna e contemporânea, a formação como ser humano e cidadão está na sua atribuição, além da própria educação básica. No caso da empresa e local de trabalho, embora o indivíduo possa optar entre várias alternativas, sendo uma empresa japonesa, dificilmente vai se desvencilhar do esquema de trabalhar em equipes e do princípio da hierarquia que rege a dinâmica do dia a dia empresarial.

\footnotetext{
${ }^{241}$ Como escreveu Elias: "Aquilo que conceptualizamos como sendo a "família", não seria de todo uma família se não houvesse filhos. A sociedade que é muitas vezes colocada em oposição ao indivíduo, é inteiramente formada por indivíduos, sendo nós próprios um ser entre os outros." (2008: 13).
} 
Essas considerações remetem para a questão da coerção que, para Giddens, pode ser de caráter material, de sanção ou de natureza estrutural (1989: 142 e ss.). A coerção material refere-se aos "limites que as capacidades físicas do corpo humano, somadas às características relevantes do ambiente físico, impõem às opções viáveis ao dispor dos agentes", incluindo ainda as capacidades sensoriais e comunicativas (op.cit.: 143). Esse tipo de coerção seria, das considerações acima, aquela verificada principalmente no caso da família.

A coerção associada às sanções tem relação com a autoridade e o poder, sendo este último considerado a fonte da coerção. Isto porque os aspectos coercitivos do poder revelam-se na forma de "sanções de vários tipos, indo desde a aplicação direta da força ou violência, ou a ameaça disso, até a expressão moderada de desaprovação." (op.cit.: 143). Na descrição das instituições feita ao longo do capítulo, esse tipo de coerção pode ser localizado em várias passagens, seja no "treinamento militar", quanto no constrangimento que a escola impõe aos alunos que não "seguem na linha".

A coerção estrutural é definida por Giddens como "a fixação de limites à gama de opções a que um ator, ou pluralidade de atores, tem acesso numa dada circunstância ou tipo de circunstância.” (op.cit.: 144). Essa concepção de coerção pressupõe certa liberdade ao indivíduo, dentro de determinadas condições. Assim, no contexto das empresas japonesas, o indivíduo pode, para se desvencilhar da relação hierárquica, tentar mudar de seção, de empresa, ou até mesmo de ramo. No entanto, nem todos podem optar por uma dessas possíveis alternativas. Dessa forma, o indivíduo deve "se conformar", aquiescer, mas este ato não é simplesmente "se tornar submisso", mas pode ser interpretado como a "aceitação consciente" e "até mesmo a aceitação "voluntária" das relações de poder mais amplas nas quais ele se insere" (ibid.). Como afirma Giddens, a "dominação" e o "poder" "não podem ser considerados unicamente em 
termos de assimetria de distribuição, mas têm de ser reconhecidos como inerentes na associação social (ou, diria eu, na ação humana como tal)" (op.cit.: 25).

Então, é possível afirmar que o indivíduo japonês se submete à relação hierárquica por temer sanções, mas não somente isso, porque qualquer sanção, exceto de natureza material, requer "algum tipo de aquiescência por parte daqueles que se lhes submetem" (op.cit. 143). Dessa forma, ele exerce o "papel” de bom funcionário obediente, sem, no entanto, estar submisso ao mandonismo do superior.

Isso vai ao encontro da tese de Nakane, que após reiteradamente afirmar que a hierarquia é predominante nas relações sociais japonesas, principalmente na relação do local de trabalho, de superior e subordinado, de forma aparentemente contraditória ${ }^{242}$ afirma que a hierarquia não implica necessariamente o superior possuir poder absoluto sobre os que estão abaixo. A partir daquilo que escreve Nakane, é possível constatar que a relação vertical não é necessariamente de domínio e submissão, mas apresenta um caráter ritualístico:

\footnotetext{
"Seja como for, em qualquer grupo pequeno (mesmo que esse grupo se orgulhe de ser democrático e afirme não ser vertical), é possível estabelecer uma hierarquia que todos possam aceitar por unanimidade. Aí é possível estabelecer uma hierarquia com alguma razão que em princípio todos possam concordar, sendo japoneses, num procedimento rápido. É isso o que denomino cultura da sociedade vertical, e a verticalidade aqui, mais do que relação de poder, significa hierarquia ritualística. Principalmente nos casos de pequenos grupos, como relatei anteriormente, até mesmo o líder tem a dificuldade de exercer o poder." (1978: 85)
}

\footnotetext{
${ }^{242}$ Cf. Sugimoto e Mouer (1982).
} 
E mais do que isso, a relação vertical está intimamente relacionada com a capacidade de "ativar ou executar" as "prerrogativas de papel" Giddens (1989:67), ou “expectativa de papel”, na terminologia de Goffman (1975), e que Nakane se expressa como "compor":

\footnotetext{
"Na realidade, uma relação interpessoal importante que a autora pretende [eu pretendo] indicar pelo termo relação vertical não é o inferior se subordinar ao superior, mas se compor de maneira adequada. Além disso, [o importante] é não esquecer do decoro da hierarquia, perante os de fora." (1978: 86)
}

Nesse sentido, a sanção que muitas vezes o indivíduo japonês sofre é por "não saber compor", ou em outras palavras, não atender à "expectativa de papel”.

Como afirma Giddens, é a rotinização que confere a segurança ontológica ao indivíduo para seguir o curso da vida cotidiana (1989:48), e isso está vinculado à expectativa de desempenho de um papel:

\footnotetext{
"Uma posição social pode ser considerada uma "identidade social" portadora de uma certa gama (um tanto difusamente especificada) de prerrogativas e obrigações que o ator, ao qual é conferida essa identidade (ou a quem "incumbe" essa posição), pode ativar ou executar: essas prerrogativas e obrigações constituem as prescrições de papel associadas a essa posição." (1989: 67).
}

Na nossa pesquisa, ocorreu uma grande correlação da empresa com a hierarquia. Pela sua própria natureza, era de se esperar que a hierarquia fosse presente e marcante nas empresas, mas a peculiaridade do relacionamento dos japoneses com o local de 
trabalho também contribui para essa realidade. Nela, o fator temporal passa a ter outro significado, e será objeto de estudo do próximo capítulo. 


\section{Capítulo 7}

\section{Dimensão temporal: idade e ordem de ingresso no meio}

\section{1- Introdução}

Nas relações sociais japonesas, o fator tempo estabelece duas referências importantes para a hierarquia social: idade e ordem de ingresso no meio.

Obviamente, a idade expressa o tempo de existência nesse mundo, e na comparação com outras pessoas, representa a ordem de nascimento: os mais velhos "vieram" antes neste mundo, e os mais novos, depois.

A ordem de ingresso no meio, por sua vez, estabelece a ordenação entre os que chegaram antes e os que chegaram depois, nas instituições e grupos sociais.

Tanto um quanto outro constituem o princípio de antiguidade, que determina que os mais velhos ou aqueles que chegaram antes tenham ascendência, prevalência, preferência e prerrogativa de liderança sobre os mais jovens e os que chegaram depois.

Na sociedade japonesa, os conceitos de senpai, "veterano", e kôhai, "novato", exprimem esse princípio de antiguidade. Por esse motivo, possuem múltiplos significados, como será analisado adiante. 


\section{2- Idade}

A idade constitui critério de distinção em qualquer sociedade, mesmo nas chamadas primitivas (Hoebel e Frost, 1984: 246 e ss). Não sendo diferente, na sociedade japonesa, há uma longa tradição de distinção por idade, que se inicia ainda no período feudal. Conforme visto nos capítulos anteriores, a primogenitura foi durante longo tempo, fator de distinção entre os irmãos, nos direitos e deveres como herdeiro e administrador da casa. O respeito aos mais velhos, sobretudo os pais, já estava presente no modo de pensar dos japoneses, no século VII, conforme visto anteriormente. No Capítulo 6, a inclusão dos ensinamentos oriundos do confucionismo no conteúdo curricular das escolas japonesas foi relatada, o que teria sido intensificada a partir de 1881 (Arichi, 1977: 44) $)^{243}$.

$\mathrm{Na}$ atualidade, o fator idade como quesito de distinção continua presente ao longo da vida do japonês. Na fase estudantil, como foi analisada no capítulo anterior, a idade é automaticamente relacionada com a série escolar, o que faz com que, na sequência da vida, o indivíduo se forme e ingresse no trabalho com pessoas da mesma idade.

Entretanto, há que se observar o fato de que a idade é um fator não muito visível, como cargos. Certamente a aparência contribui para isso, podendo causar enganos, e nem sempre a idade é uma informação disponível. Perguntar a idade para uma mulher no Japão é considerado indelicado, assim como no Brasil. Além disso, existe o fato de que no Japão, o ano, na prática, se inicia em abril, quando muda o ano da era imperial e também marca o começo do ano fiscal e letivo. Assim, quem nasce nos meses de janeiro a março, acaba ingressando no "ano anterior" daqueles que nascem a partir de abril. 
Dessa forma, parece ser razoável que, na nossa amostragem, em termos de grau de hierarquia, a idade apareça na posição menos marcante do que a relação "superiorsubordinado" e a relação "senpai-kôhai":

Tabela 21: Distribuição das respostas sobre a comparação do grau de hierarquia entre diferentes relações

\begin{tabular}{|c|c|c|c|c|c|c|c|}
\hline & $1^{\circ}$. & $2^{\circ}$ & $\mathbf{3}^{\mathbf{o}}$ & $4^{\circ}$. & $5^{\circ}$. & s/resp. & total \\
\hline $\begin{array}{l}\text { Relação pais- } \\
\text { filho }\end{array}$ & 27 & 8 & 11 & 23 & 1 & 11 & 81 \\
\hline$\%$ & 33,5 & 9,8 & 13,6 & 28,3 & 1,2 & 13,6 & 100 \\
\hline $\begin{array}{l}\text { Relação entre } \\
\text { irmãos }\end{array}$ & 3 & 8 & 5 & 14 & 38 & 13 & 81 \\
\hline$\%$ & 3,7 & 9,8 & 6,2 & 17,3 & 47,0 & 16,0 & 100 \\
\hline $\begin{array}{l}\text { Relação } \\
\text { superior- } \\
\text { subordinado }\end{array}$ & 42 & 19 & 7 & 3 & 2 & 8 & 81 \\
\hline$\%$ & 52,1 & 23,4 & 8,6 & 3,7 & 2,4 & 9,8 & 100 \\
\hline $\begin{array}{l}\text { Relação sempai- } \\
\text { kôhai }\end{array}$ & 1 & 32 & 18 & 14 & 6 & 10 & 81 \\
\hline$\%$ & 1,2 & 39,6 & 22,2 & 17,3 & 7,4 & 12,3 & 100 \\
\hline $\begin{array}{l}\text { Relação mais } \\
\text { velho-mais novo }\end{array}$ & 4 & 8 & 27 & 13 & 17 & 12 & 81 \\
\hline$\%$ & 4,9 & 9,8 & 33,5 & 16,0 & 21,0 & 14,8 & 100 \\
\hline
\end{tabular}

Mas se a pesquisa fosse realizada somente nas ilhas de Okinawa, o resultado poderia ser diferente. Oriunda de outra tradição cultural ${ }^{244}$ e formada por comunidades,

\footnotetext{
${ }^{243}$ Segundo o estudo de Muta, o conteúdo que valoriza e sugere respeito aos pais estava presente já na primeira década do período Meiji (1868-1912) (1996: 88).

${ }^{244}$ Okinawa era Ryukyu, um reino existente desde o século XV e que foi anexado ao Japão no final do século XIX.
} 
na maioria pequenas, que se espalham em trinta ilhas habitadas, a idade teria sido ao longo do tempo o fator preponderante para o estabelecimento da hierarquia ${ }^{245}$. Entretanto, a incorporação da tradição japonesa tem modificado esse quadro, e "os jovens já não pensam assim",246.

Até aproximadamente duas décadas atrás, era quase regra que os jovens japoneses cedessem lugar para os idosos nos trens e metrôs do Japão. Embora isso ainda possa ser observado nas pequenas e médias cidades, nas grandes metrópoles, o contrário tem sido regra, mesmo quando se trata de assentos reservados para idosos e deficientes $^{247}$. Isso pode ilustrar o fato de que o pensamento em torno da idade como fator de distinção tenha mudado muito nas últimas décadas, embora isso tenha relação indireta com a hierarquia, e um maior vínculo com a etiqueta e os bons modos.

\section{3- Ordem de ingresso no meio}

O princípio de antiguidade estabelece que aqueles que ingressaram antes no meio, ou seja, a escola, a empresa e outras instituições e grupos sociais, gozam de direitos e privilégios sobre aqueles que ingressaram posteriormente. Portanto, o critério é cronológico e constitui outra dimensão temporal do estabelecimento da hierarquia na sociedade japonesa.

Elias e Scotson destacaram em Os Estabelecidos e os Outsiders: Sociologia das relações de poder a partir de uma pequena comunidade o princípio de antiguidade

\footnotetext{
${ }^{245}$ Informante masculino, jornalista, 49 anos, em 28 de outubro de 2011, em Okinawa.

246 Ibid. Essa questão será retomada nas Conclusões finais.

247 Ver, por exemplo, um blog comentando uma reportagem ilustrada condenando essa realidade, em http://www.yukawanet.com/archives/3985776.html. Há outro site em que os internautas justificam porque
} 
como fator determinante no estabelecimento da superioridade social e moral de um grupo, os "estabelecidos", em relação aos "outsiders", numa pequena cidade da Inglaterra (2000). Nesse estudo, sendo o objetivo desvendar o mecanismo pelo qual dois grupos aparentemente homogêneos, em se tratando de classe social, nacionalidade ou etnia, possuírem status diferentes, a ênfase é dada na coesão interna do grupo dominante, assim como a constituição da autoimagem positiva, os recursos de coerção e de exclusão do grupo "forasteiro", mas é ilustrativo no sentido de demonstrar que o princípio de antiguidade é válido também num país ocidental, não sendo exclusivo da sociedade japonesa. Embora não se possa negar a dimensão coletiva do princípio de antiguidade entre os japoneses - a formatura com o mesmo grupo que iniciou os estudos e o ingresso concomitante na carreira constituem fatores que possibilitam apontar sempre "os que ingressaram antes", no plural - é inegável que esse princípio se expressa, em primeiro lugar, no nível interpessoal individual, a relação entre aquele que ingressou antes, portanto, que goza do princípio de antiguidade, denominado senpai ("veterano") e aquele que ingressou posteriormente, denominado kôhai ("novato"). Prova disso é que uma vez estabelecido o referido status, este se mantém, como no caso do "veterano" da universidade [daigaku no senpai], que mesmo após a formatura, perdura para o resto da vida ${ }^{248}$.

não cedem lugar aos idosos: http://blog.livedoor.jp/saboten03-higradevip/archives/67078845.html . Ambos acessados em 12 de janeiro de 2011.

${ }^{248}$ Um exemplo não de universidade, mas de condição semelhante, pode ser o caso de um político influente do Partido Democrático, atualmente no poder, no Japão, que chegou a disputar o cargo de primeiro-ministro, em 2011, e, atualmente, ocupa o cargo de presidente da comissão que trata de políticas públicas do partido. Esse político é egresso do Matsushita Seikeijuku, um curso de formação de líderes, fundado em 1979, pelo falecido Matsushita Konosuke, também conhecido como fundador da Panasonic. Os formados desse curso atuam e se destacam em diversas áreas, incluindo o primeiro-ministro Noda que é da primeira turma, além de outros 37 membros atuais do parlamento japonês. Mas o fato é que esse político é da oitava turma, e nos encontros de confraternização dos formandos do referido curso, é obrigado a seguir a ordem dos senpai e organizar o pedido de cerveja, fazendo a intermediação com o garçom. Nesses encontros, o assento na mesa também é definido de acordo com a ordem de formatura das turmas. Isso serve para demonstrar o quanto a relação entre senpai e kôhai está presente no círculo social dos japoneses, independentemente do prestígio que a pessoa possa ter, fora dele. Certamente, muitos desses "veteranos" que mandam nesse político não ocupam a posição social com o prestígio e poder que 


\subsection{1- Fase escolar}

Ficou evidente, na pesquisa realizada, que a noção de hierarquia é adquirida principalmente na escola, com maior frequência nas chamadas atividades de departamentos [bukatsu] ou "clubes" [kurabukatsudô]. Essas atividades são extracurriculares e existem em todas as escolas do segundo e terceiro ciclos do Japão ${ }^{249}$, com preponderância do setor de esporte coletivo (baseball, basquete, vôlei etc.), esporte individual (atletismo, natação, esgrima, alpinismo, etc.), artes marciais (karatê, judô, kendô, etc.), além de artes tradicionais como cerimônia do chá, ikebana, caligrafia e afins. As atividades iniciais foram introduzidas ainda no período Meiji, tendo como finalidade "mais do que desenvolver o físico dos estudantes, para aprimorar o aspecto espiritual e de virtude" (Nakamura, 2009: 16).

A passagem seguinte, uma descrição da natureza dos "clubes" feita por Kawamura (1999), retrata como estes envolvem os alunos, ou melhor, como os alunos são obrigados a se envolverem de uma forma que se submetem ao controle social do ambiente peculiar que é uma escola japonesa:

“Ainda dentro do espírito da formação integral, a escola japonesa busca a sua integração com a família e a comunidade, a partir da organização de grupos que participam de diversas atividades escolares, além de visitas periódicas dos professores às moradias e da organização de grupos de crianças para eventos extracurriculares, como os clubes de esportes, músicas, artes etc. Estes clubes funcionam algumas vezes por semana, ou até

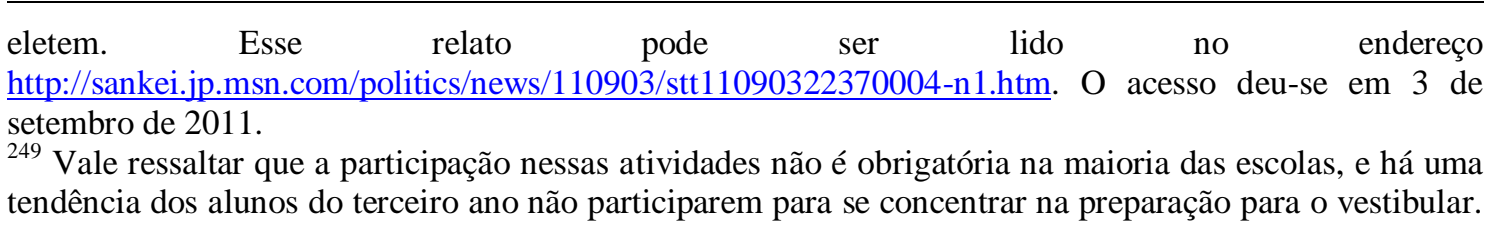


mesmo diariamente em cursos ginasial e colegial, após o término das aulas, inclusive aos sábados após o horário normal e também, às vezes, aos domingos. As exigências de assiduidade às atividades do clube, em busca do desempenho perfeito na atividade escolhida, se, de um lado, traz satisfação ao estudante no processo de aperfeiçoamento esportivo, artístico etc. e no espírito de pertencer a um grupo, de outro, traz a exaustão física e psicológica, pelo contínuo controle social decorrente. Através desses clubes há o controle moral e psicológico dos estudantes pelo professor responsável e pelos colegas. Por exemplo, o desvio de uma estudante das normas e regras de conduta grupal de um clube de badminton de uma escola colegial levou os demais membros a pressioná-la, coletivamente, todas as vezes em que ocorria um deslize. Mesmo os estudantes japoneses, quando fogem da regra, recebem sanções não só da escola e do corpo docente, mas principalmente dos colegas. Essa prática estende-se a colegas estrangeiros, muitas vezes, de forma mais acentuada. Por outro lado, não se incorporar em clubes das escolas significa escolher o distanciamento dos demais alunos, exceto daqueles nas mesmas condições, que são em proporção reduzida." (1999: 185-7) $)^{250}$.

Embora Kawamura não tenha mencionado nesse trecho, certamente faz parte das referidas regras a observância da hierarquia resultante da relação senpai-kôhai. Ademais, dos "colegas" que pressionam coletivamente para que aquele que apresentou comportamento "desviante" entre novamente "no eixo", quem por direito tem autoridade é o senpai, dado o princípio de antiguidade. Certamente, esse e os demais colegas que pressionam o colega para corrigir a conduta sentem-se superiores ao atribuírem para si o papel de arautos da regra; são aqueles que internalizaram a regra social e a reproduzem como estrutura social. Essa questão ainda será retomada no final do capítulo.

Segundo Nakamura, na média, cerca de 50\% dos alunos de uma escola participam de algum departamento ou clube, sendo que 30\% deles são de setores esportivos (2009: 29). 
Outro relato que mostra esse processo de internalização da regra é o de um informante que tem dois filhos, e é ilustrativo:

"Durante o chûgakko e $k \hat{o} k \hat{o}^{251}$, fiz parte do bukatsu. Joguei basquete. De fato o relacionamento com o senpai era rigoroso, não podíamos discordar dele. Mas acho que no meu tempo já tinha atenuado um pouco, ouvi de alguns veteranos que na época deles, no inverno, acordavam cedo para esquentar água e aquecer o piso do vestiário, para que os senpais não tivessem o incômodo de pisar o azulejo gelado. Em todo caso, sempre eduquei meus filhos afirmando que no bukatsu as coisas eram assim. Quando meu filho mais velho quis jogar basquete também, fiquei contente, mas apreensivo também. Sabe como é, essa garotada é diferente da nossa geração. Não sei se suportaria... Mas depois fui constatar que não havia mais aquele rigor. Hoje em dia, as coisas são mais "largadas", enfim, mudou muito. Isso para mim, foi uma surpresa. Fiquei um pouco frustrado, não sei, desapontado."252

Esse depoimento traz a ideia do tipo de hierarquia existente no bukatsu, e ao mesmo tempo como isso é, de certa maneira, internalizado pelos membros, a ponto de criar simpatia, tanto que ficou desapontado com a "lassidão" atual. Ao mesmo tempo, serve para ilustrar a mudança na relação hierárquica entre gerações, embora para se verificar uma tendência mais geral sobre o bukatsu, se necessite de pesquisas mais detalhadas e aprofundadas.

\footnotetext{
${ }^{250}$ Os grifos são da autora.

${ }^{251}$ Respectivamente, "ginásio" e "ensino médio". Cf. Capítulo 6, seção 6.3.1.2.

${ }^{252}$ Autônomo, 45 anos, em 15 de outubro de 2011, em Miyazu, Quioto.
} 


\subsection{2- Local de trabalho}

Nakane foi uma das pioneiras a mencionar a ordem de ingresso no meio como critério de hierarquização, principalmente como fator de desempate, ou seja, quando há homogeneidade dos membros, principalmente pelos atributos e competência, a hierarquia é estabelecida pela ordem de ingresso no $\operatorname{lugar}^{253}$ e o tempo de permanência:

A hierarquia pode estar evidente ou não. Sendo uma organização com organograma estabelecido, é evidente que, além da hierarquia formal de posições como supervisor, supervisor-adjunto e encarregado etc., possui outra pela ordem de ingresso na empresa, mas mesmo nos casos em que não seja uma organização com essa característica, de um modo geral, a ordem de ingresso nesse grupo tem sido o índice de estabelecimento da hierarquia. Se a ordem de ingresso for a mesma, são empregadas a idade ou a ordem de formatura. Além disso, nos casos em que são nascidos na mesma comunidade, a antiguidade e o status da família passam a ser o fator de hierarquização (1978: 84).

Nakane afirma que o princípio de antiguidade é empregado também na promoção e na ascensão na carreira. Assim, segundo essa autora, sendo mais presente no cotidiano, o quesito de ordem de ingresso no lugar tende a prevalecer na definição da hierarquia, sobre os tipos de ocupação, o status de nascimento e outras formas de diferenciação (1967: 72).

Obviamente, as empresas japonesas têm sofrido transformações, conforme visto no capítulo anterior. Mas é significativo observar que, na nossa amostragem, a relação “senpai-kôhai" tenha superado a ordenação por desempenho pessoal (cf. 8.23):

\footnotetext{
${ }^{253}$ O chamado ba, cf. seção 2.3.2 do Capítulo 2, assim como a nota 9.
} 
Tabela 22: Distribuição das respostas sobre a gradação da hierarquia nas relações no local de trabalho

\begin{tabular}{|c|c|c|c|c|c|}
\hline & $\mathbf{1}^{\mathbf{0}}$ & $\overline{2^{\circ}}$. & $\mathbf{3}^{\mathbf{0}}$ & s/resp. & total \\
\hline $\begin{array}{l}\text { Relação superior- } \\
\text { subordinado }\end{array}$ & 68 & 8 & 1 & 4 & 81 \\
\hline$\%$ & 84,1 & 9,8 & 1,2 & 4,9 & 100 \\
\hline Rel. senpai-kôhai & 2 & 49 & 24 & 6 & 81 \\
\hline$\%$ & 2,4 & 60,5 & 29,7 & 7,4 & 100 \\
\hline $\begin{array}{l}\text { Ordenação pelo } \\
\text { desempenho } \\
\text { profissional }\end{array}$ & 6 & 20 & 45 & 10 & 81 \\
\hline$\%$ & 7,4 & 24,7 & 55,6 & 12,3 & 100 \\
\hline
\end{tabular}

De qualquer forma, nos moldes da empresa japonesa, se se pretende ter ascensão na carreira, é preciso se adaptar ao esquema vertical de "senpai-kôhai" para chegar ao cargo de gerência. Os intransigentes são paulatinamente afastados da carreira de chefia, sendo os mais "dóceis" escolhidos como sucessores dos postos chave da administração. É impossível chegar ao alto escalão contrariando o senpai (Mori, 2004: 72).

Não somente para galgar posições na empresa, a observância da relação "senpaikôhai" é imprescindível para executar atividades profissionais, como nos casos relatados. Segundo um informante que é formado numa escola de culinária, a prática da profissão se aprendia no estágio, onde os senpais eram, na prática, os instrutores ${ }^{254}$ :

\footnotetext{
${ }^{254}$ Funcionário de firma, 47 anos, em 14 de novembro de 2011, em Yokohama, Kanagawa.
} 
"Não havia alternativa, só se aprendia assim. Cada vez que cometíamos erros, levávamos um “pisão" do senpai. Às vezes, o cliente estava na nossa frente, do outro lado do balcão, e o senpai quase que amassando nosso pé. Ele ria para o cliente, e forçava mais ainda. Mas nós aceitávamos isso porque para nós, fazia parte do treinamento, da aprendizagem."

Indagado se essa prática ainda continua, esse informante deu uma resposta bastante ilustrativa:

\footnotetext{
"Hoje em dia, se fizer isso, o aprendiz não retorna no dia seguinte. A escola de culinária fecharia. Outro dia, mesmo um colega da minha idade, que não "pegava pesado" assim, disse que está difícil treinar os jovens de hoje.”
}

Assim, percebe-se que há uma transformação em curso, que em muito atenua ou anula a submissão que era inerente à observação da hierarquia, nos meios profissionais. Mas certamente a dependência em relação ao veterano de ofício persiste, e será necessário observar até que ponto a própria posição de senpai vai continuar a ser considerada, como posição importante no meio profissional. Mas enquanto o Japão não abandonar a tradição de se trabalhar em equipe, se atribuindo tarefas inter-relacionadas com funções dependentes entre si, dificilmente o peso do senpai será totalmente descartado. 


\section{4- Considerações finais do capítulo}

A relação "senpai-kôhai" descrita ao longo do capítulo também apresenta tanto a coerção associada às sanções quanto a coerção estrutural ${ }^{255}$. Mas é possível afirmar que, em se tratando dessa relação do tipo "ordem de ingresso no meio" que não seja na empresa, ou seja, em grupos como cursos, associação, etc., prevalece mais a coerção estrutural do que aquela, uma vez que, na essência, trata-se de uma relação interpessoal no nível de dois indivíduos e, nesse sentido, a relação não é tão rigorosa a ponto de sofrer sanções, e, além do mais, o indivíduo pode, a qualquer momento, se retirar da relação.

Como afirmou uma informante, há indícios de que a relação "senpai-kôhai" de formados de uma escola é mais persistente e duradoura entre os homens, enquanto que, entre as mulheres, tende a desaparecer com o casamento ${ }^{256}$. Isso não deixa de refletir a peculiaridade do casamento entre os japoneses em que a esposa, ao se casar, perde muito das relações sociais outrora constituídas, para se dedicar ao lar, mas não deixa de ser um exemplo ilustrativo para mostrar que de certa forma, ela tem como se desvencilhar de uma relação que, por princípio, é para o restante da vida. Ou seja, conforme a discussão anterior, ela simplesmente "desce do palco" e abandona o "papel" que lhe foi atribuída.

Instados a responder à pergunta "Das definições abaixo sobre senpai ("veterano"), qual você considera mais adequado?", os informantes que responderam a "pessoa mais velha" superou aqueles que responderam "aquele que ingressou na empresa ou que se empregou antes", de forma surpreendente (cf. 8.12):

\footnotetext{
${ }^{255}$ Cf. conclusões finais do Capítulo 6.
} 
Tabela 23: Distribuição das respostas sobre a definição mais adequada de senpai ("veterano")

\begin{tabular}{|l|c|c|l|c|c|c|c|}
\hline & $\begin{array}{l}\text { pessoa } \\
\text { mais } \\
\text { velha }\end{array}$ & $\begin{array}{l}\text { aquele que se } \\
\text { formou antes } \\
\text { (universidade ou } \\
\text { ensino médio) }\end{array}$ & $\begin{array}{l}\text { aquele que } \\
\text { ingressou na } \\
\text { empresa ou que } \\
\text { se empregou } \\
\text { antes }\end{array}$ & $\begin{array}{l}\text { aquele que tem } \\
\text { competência ou } \\
\text { técnica superior }\end{array}$ & outros & s/inf. & total \\
\hline No. & 32 & 6 & 23 & 8 & 2 & 10 & 81 \\
\hline$\%$ & 39,6 & 7,4 & 28,4 & 9,9 & 2,4 & 12,3 & 100 \\
\hline
\end{tabular}

É necessário verificar a influência da ocupação que os membros de cada grupo de informantes exercem nesse posicionamento, mas esse fato confirma a multiplicidade do emprego de "senpai", e, por conseqüência, do "kôhai", uma vez que este é definido em função daquele.

Acima de tudo, esse resultado corrobora a tese de que esses conceitos exprimem o princípio de antiguidade, que tanto se refere à idade quanto à ordem de ingresso no meio.

Assim, na sociedade japonesa, a relação "senpai-kôhai" está imbricada com os estudos (e aprendizagem no sentido amplo), o trabalho e com qualquer atividade que seja executada em grupo social, ou que pressupõe antecedentes e precursores. A realidade nos mostra que poucos setores da atividade humana dispensam essas características, e por isso, a relação "senpai-kôhai" pode ser considerada aquela que, relativamente, mais está presente na vida do indivíduo japonês.

\footnotetext{
${ }^{256}$ Informante feminino, 50 anos, serviço social, entrevistada em 16 de agosto de 2011, em Yamagata.
} 


\section{Conclusões finais}

Considerando-se que as conclusões pontuais foram desenvolvidas no final de cada capítulo, cabe nessa seção fazer as considerações gerais, para o propósito de conclusão do trabalho.

Tendo como objetivo analisar a hierarquia social no contexto da sociedade japonesa contemporânea, o presente estudo enfocou a estrutura hierárquica, na qual é possível identificar, por definição, as posições "superior" e "inferior" ou "superior" e "subordinado", e a consciência hierárquica dos agentes japoneses. No Capítulo 3, uma síntese da história do Japão procurou destacar as passagens importantes no que se refere à dominação hierárquica e à legitimação dessa dominação ao longo do tempo. Nessa descrição, ficou evidente que pelo menos a partir da constituição do Estado centralizado, no século VII, como evolução das comunidades que começaram a se organizar já por volta do século I, os japoneses sempre mantiveram ou viveram numa sociedade hierarquizada, até o pleno século XX. Somente após o término da Segunda Guerra Mundial, é que os japoneses passam a poder vislumbrar uma sociedade sem dominação hierárquica, embora, no nível das relações sociais do cotidiano, a hierarquia continue existindo com preponderância no local de trabalho. É possível afirmar, com certo exagero, que os japoneses passaram vários séculos de rotinização, no sentido empregado por Giddens, em que a hierarquia se tornou uma referência indispensável para as interações sociais no cotidiano, que se expressa na "necessidade de sempre estabelecer a ordem hierárquica", como afirmou Nakane. Como afirma Giddens, "a temporalidade é tão inseparável de um pequeno segmento de interação quanto da mais longa das longues durées" (1989: 114). 
A tipificação e a identificação das posições decorrentes da hierarquia foram, nesse trabalho, estudadas a partir da significação que os agentes conferem nas relações sociais, principalmente no âmbito da família, da escola e do local de trabalho. A relação com a estrutura de classes foi descartada, nos dois sentidos que esse termo pode possuir. No sentido restrito tal qual formulado por Marx, como instrumento analítico para descrever as contradições do sistema capitalista moderno, o impedimento deu-se essencialmente por duas razões: primeira, que a sociedade capitalista só se instala no Japão no século XX, sendo que a hierarquia social é anterior a ela; em segundo lugar, a classe social é um conceito elaborado para analisar essencialmente a dominação econômica, enquanto que a hierarquia social exprime a dominação que tem base cultural, como foi analisado ao longo do trabalho. Por outro lado, a classe social como expressão da estratificação social mostrou-se não apresentar vínculos com a consciência hierárquica, conforme foi demonstrado no Capítulo 5. Nesse sentido, na sociedade japonesa contemporânea, a hierarquia deve ser analisada no nível das posições sociais, que são definidas como "constituídas estruturalmente como interseções específicas de significação, dominação e legitimação que se relacionam com a tipificação dos agentes" e ainda envolvem a "especificação de uma "identidade" definida numa rede de relações sociais" (Giddens, 1989: 67).

A partir das contribuições de Benedict e Nakane, as instituições família, escola e empresa foram escolhidas para a análise.

$\mathrm{Na}$ família, a hierarquia entre os irmãos praticamente inexiste, enquanto que, entre casais, a tendência também é a de se extinguir, na geração jovem. Verifica-se que existe, ainda, a consciência hierárquica entre pais e filhos, embora em menor grau de dominação do que no passado. Assim, a tese defendida por Benedict, de que a 
consciência hierárquica surge inicialmente no seio da família e depois se estende a várias esferas da vida, não pode ser sustentada.

Como que corroborando a tendência de desaparecimento da noção de hierarquia na família, a escola se projetou no nosso estudo como a instituição em que os japoneses “despertam” para a consciência hierárquica, sobretudo nas atividades extracurriculares denominadas bukatsu ou kurabu katsudô. Verificou-se a importância da dimensão temporal para o estabelecimento da hierarquia, primeiro definindo pela gradação da idade que corresponde às séries escolares e, em segundo lugar, mas de maior importância, determinando a relação senpai-kôhai, que dependendo da área do "clube", se esportiva ou não, pode ser de dominação branda ou forte.

No local de trabalho ou nas empresas, como não poderia deixar de ser, existe a hierarquização por cargos, o que constitui a relação hierárquica formal. Entretanto, a relação senpai-kôhai, que é estabelecida pela ordem de ingresso no meio ${ }^{257}$, pode exercer maior influência por estar vinculada ao treinamento e capacitação do funcionário, em outras palavras, o desempenho profissional depende, em larga medida, do bom encaminhamento dessa relação. Ainda, se considerarmos o sistema de promoção tradicional japonês, a ordem de ingresso no meio tende a coincidir com a relação hierárquica formal. Sendo assim, a relação senpai-kôhai constitui a principal referência hierárquica, por exprimir idade, ordem de ingresso no local de trabalho e a hierarquia formal. Isso foi expresso de forma sintetizada na questão 8.24 da nossa pesquisa, que convém ser aqui repetida:

\footnotetext{
${ }^{257}$ Como foi examinado no Capítulo 7, isso não quer dizer que esse princípio anule outros, pois, a idade tende a coincidir com a ordem de ingresso, e mesmo a relação senpai-kôhai do tempo escolar pode interferir, no caso em que dois indivíduos tenham a mesma origem em termos de formação escolar, embora em menor grau do que na relação em questão.
} 
Tabela 24: Distribuição das respostas sobre a comparação do grau de hierarquia entre diferentes relações

\begin{tabular}{|c|c|c|c|c|c|c|c|}
\hline & $\mathbf{1}^{\circ}$. & $2^{\circ}$ & $\overline{3^{\circ}}$. & $44^{0}$ & 5 & s/resp. & total \\
\hline Relação pais- & 27 & 8 & 11 & 23 & 1 & 11 & 81 \\
\hline \multicolumn{8}{|l|}{ filho } \\
\hline$\%$ & 33,5 & 9,8 & 13,6 & 28,3 & 1,2 & 13,6 & 100 \\
\hline Relação entre & 3 & 8 & 5 & 14 & 38 & 13 & 81 \\
\hline$\%$ & 3,7 & 9,8 & 6,2 & 17,3 & 47,0 & 16,0 & 100 \\
\hline Relação & 42 & 19 & 7 & 3 & 2 & 8 & 81 \\
\hline$\%$ & 52,1 & 23,4 & 8,6 & 3,7 & 2,4 & 9,8 & 100 \\
\hline Relação senpai- & 1 & 32 & 18 & 14 & 6 & 10 & 81 \\
\hline$\%$ & 1,2 & 39,6 & 22,2 & 17,3 & 7,4 & 12,3 & 100 \\
\hline $\begin{array}{l}\text { Relação mais } \\
\text { velho-mais novo }\end{array}$ & 4 & 8 & 27 & 13 & 17 & 12 & 81 \\
\hline$\%$ & 4,9 & 9,8 & 33,5 & 16,0 & 21,0 & 14,8 & 100 \\
\hline
\end{tabular}

Antes de prosseguir, convém retomar algumas discussões acerca das contribuições dos autores clássicos e a implicação delas no nosso estudo.

$\mathrm{Na}$ crítica ao trabalho de Nakane, Yoneyama apontou para a diversidade regional japonesa, conforme mencionado no Capítulo $2^{258}$. Na medida do possível, a pesquisa de campo realizada procurou contemplar todas as regiões do Japão, mas alguns acontecimentos de força maior acabaram colocando obstáculos, isto quando não inviabilizou a própria viagem à região pretendida. Inegavelmente, a tragédia natural de 11 de março fez com que excluíssemos a região afetada. No entanto, foi possível executar a pesquisa em algumas províncias dessa região, como as de Fukushima e 
Iwate, mesmo contra as recomendações em contrário. A chuva torrencial seguida de tufão que atingiu o arquipélago, em setembro, causou estragos significativos principalmente na região central, que inviabilizaram a ida a Mie, Wakayama e Nara, embora nesta última tenhamos conseguido informantes graças à colaboração de conhecidos.

A despeito dessas adversidades, a pesquisa foi realizada e no que se refere à hierarquia social, não foi possível constatar, na nossa amostragem, alguma diversidade regional, com exceção de Okinawa. Conforme relatado no Capítulo 7, os moradores estão perdendo os valores tradicionais assentados nas pequenas comunidades, e estão adotando o padrão de relação predominante da "ilha principal", caracterizado pela observância da hierarquia. Como relatou o informante residente em Naha, capital de Okinawa, "o estabelecimento das grandes empresas da "ilha principal" tem alterado a relação social no trabalho". Indagado o que teria sido alterado, respondeu que "a hierarquia ficou mais forte", que "antes não havia necessidade de observar a hierarquia e usar, por exemplo, as expressões de tratamento, mas ultimamente tem sido assim" 259. Isso pode ser mais uma evidência de que assim como o dialeto local está sendo suplantado pela língua oficial culta, as relações sociais próprias da ilha, no que se referem ao local de trabalho, estão sendo substituídas por uma relação mais rígida, no aspecto hierárquico, consumando assim a tendência à uniformização da sociedade japonesa como um todo.

Por outro lado, havia a crítica feita por alguns autores de que os estudos sobre o Japão dessa fase de 1960-70 generalizaram o perfil que é peculiar a certos segmentos sociais, a "elite" da sociedade japonesa ${ }^{260}$. Esse trabalho não entrou no mérito da

\footnotetext{
${ }^{258}$ Cf. o trecho final da seção 2.3.2.

${ }^{259}$ Informante masculino, jornalista, 49 anos, em 28 de outubro de 2011, em Okinawa.

${ }^{260}$ Cf. o trecho final da seção 2.3.2.
} 
questão, considerando-se, ainda, que é discutível o que seria essa "elite", ou seja, é possível dizer que o conceito não está claro. Em todo caso, enfocando o setor médio da sociedade japonesa, ou o "homem de rua" de Benedict ${ }^{261}$, o nosso estudo demonstrou a pertinência da consciência hierárquica e como isso está arraigado nesse setor.

É necessário acrescentar que os autores sobre a sociedade japonesa dessa fase, incluindo Benedict e Nakane, frequentemente são rotulados, muitas vezes de forma pejorativa, como sendo da corrente denominada japonologia [nihonjinron]. Essas obras, segundo alguns críticos, têm em comum destacar a suposta exclusividade, o caráter único, os traços "inconfundíveis" e "inigualáveis" da sociedade ou cultura japonesa ${ }^{262}$. Entretanto, esses trabalhos precisam ser considerados no seu devido tempo, é pertinente afirmar que a avaliação desse caráter "único" tendia para valoração positiva ou negativa, dependendo da época e do interesse do autor ${ }^{263}$. Assim, a posição adotada no presente estudo é a de que no que se referem à hierarquia social, suas considerações são válidas como ponto de partida, como foi amplamente desenvolvido no Capítulo 2.

Antes de finalizar, é pertinente indagar por que os japoneses não estudam a hierarquia da própria sociedade, tanto quanto nós achamos que deveriam, ou damos valor para esse tema. Além da pesquisa SSM, mencionada no Capítulo 5, as grandes pesquisas realizadas nacionalmente, como JGSS (Japan General Social Surveys) ${ }^{264}$ e a

\footnotetext{
${ }^{261}$ No capítulo introdutório, a autora assim resume o objetivo do trabalho: "Este livro diz respeito, pois, aos hábitos esperados e tidos como consagrados no Japão. Diz respeito a situações em que todo japonês pode contar com cortesia e a situações em que não pode, trata de quando sente vergonha, quando sente embaraço, procura observar o que ele exige de si próprio. A autoridade ideal para qualquer afirmativa deste livro seria o proverbial homem de rua. Seria um qualquer. Isto não significa que este um qualquer teria sido colocado pessoalmente em cada circunstância particular. Não significa também que qualquer um reconheceria ser assim sob tais condições. O objetivo de um estudo como este é descrever atitudes profundamente impregnadas de pensamento e conduta. Mesmo não o atingindo, este foi, todavia, o seu ideal" (2002: 21). Grifo nosso.

${ }^{262}$ Ver, por exemplo, Sugimoto e Mouer (1982).

263 Ver Funabiki (2003), Minami (1994) e Aoki (1990).

${ }^{264}$ Cf. Tanioka; Nitta; Iwai ( 2008).
} 
"Pesquisa de Pensamento dos Japoneses" [Nihonjin no Ishikichôsa $]^{265}$, não tratam do assunto, assim como as pesquisas realizadas pela iniciativa privada ${ }^{266}$. Nesse sentido, a pesquisa de campo realizada para ilustrar esse estudo teve caráter inédito.

Uma parte da resposta a essa pergunta pode estar contida na reação de um informante que, após a recusa inicial, observando de lado a colega de trabalho a preencher o questionário, mudou de ideia e pediu para também participar da pesquisa. Após responder às questões, comentou que nunca havia pensado a respeito da hierarquia, que, estando sempre em posição de subordinado ou inferior, "era normal que devesse respeitar e obedecer às ordens que vinham de cima", e que a partir daquele momento, começaria a "refletir mais" sobre o assunto ${ }^{267}$.

Esse sentimento que, em vários momentos da nossa pesquisa, pareceu estar presente no íntimo dos informantes, a julgar pela reação deles, suscitou reações muitas vezes opostas e extremadas. Alguns demonstraram bastante interesse por considerarem que o tema era importante, colaboraram e deram apoio mais do que o imaginado, como um centro comunitário que dispôs seus funcionários no pleno horário de expediente para que pudessem conceder as entrevistas. Para outros, o tema provocava um malestar, como uma informante que afirmou que as perguntas eram "pessoais demais"268, ou uma senhora que simplesmente disse que "não tinha como responder a essas perguntas"269. Isto quando não devolviam o questionário em branco.

Assim, muitas vezes, o ineditismo do assunto, assim como o fato de questionar sobre certas convicções e opiniões sobre as quais nunca tinham pensado ou respondido, poderia ter causado certo embaraço.

\footnotetext{
265 Cf. NHK Hoso Bunka Kenkyujo: (2010)

${ }^{266}$ Ver, por exemplo, Fujita Mirai Keiei Kenkyujo (2001), e Nihon Rodo Kenkyu Kiko (2000).

${ }^{267}$ Funcionário público, 31 anos, em 31 de agosto de 2011, em Hakodate, Hokkaido.

${ }^{268}$ Em 17 de outubro de 2011, em Nagoya.

${ }^{269}$ Em 2 de novembro de 2011, em Matsuyama, Ehime.
} 
Mas mais do que isso, é necessário considerar uma conjuntura desfavorável, para não dizer hostil em alguns casos, para a realização de pesquisas sociais no Japão. Por exemplo, a pesquisa SSM de 2005 teve apenas 44,1\% de taxa de retorno de questionários válidos, ou seja, nem a metade do total distribuído foi devolvida ${ }^{270}$. Em 2006, o parlamento japonês aprovou uma lei que restringe o acesso ao banco de dados de residentes, onde contém informações, entre outras, sobre o nome, o endereço e o telefone dos moradores de um dado bairro, e também reformou a lei eleitoral, vedando o acesso à lista de eleitores, a não ser para pesquisas que tenham caráter comprovada de utilidade pública (Hasegawa, 2008). Como consequência, existem várias prefeituras e órgãos públicos que praticamente vetam o acesso aos dados (ibid.). Por outro lado, existe uma indisposição e recusa por parte da população em cooperar com as pesquisas. Segundo Seiyama (2008), isso se deve a diversos fatores, como o aumento da consciência de privacidade, assim como a mudança de hábitos, como a ausência na residência em horários normais, acessíveis ao pesquisador, e a descrença em pesquisas sociais. De fato, vários órgãos governamentais e entidades sociais recusaram a cooperação à nossa pesquisa, o que reduziu consideravelmente a nossa amostragem, num contexto em que a entrevista ou a aplicação de questionário teriam que ser feitas em curto espaço de tempo.

Por fim, convém retomar a discussão de Nakane, de que a relação vertical não é necessariamente de domínio e submissão, e apresenta um caráter ritualístico:

\footnotetext{
${ }^{270}$ Cf. MIWA, S. Gendai Nihon ni okeru Sedaikan Idô to Sedainai Idô 1995-2005 (Mobilidade Intergeracional e Intrageracional no Japão Contemporâneo: 1995-2005). In: http://www.crs.or.jp/backno/No629/6291.htm. Acesso em 18 de janeiro de 2012.
} 
"Seja como for, em qualquer grupo pequeno (mesmo que esse grupo se orgulhe de ser democrático e afirme não ser vertical), é possível estabelecer uma hierarquia que todos possam aceitar por unanimidade. Aí é possível estabelecer uma hierarquia com alguma razão que em princípio todos possam concordar, sendo japoneses, num procedimento rápido. É isso o que denomino cultura da sociedade vertical, e a verticalidade aqui, mais do que relação de poder, significa hierarquia ritualística. Principalmente nos casos de pequenos grupos, como relatei anteriormente, até mesmo o líder tem a dificuldade de exercer o poder. A dinâmica de pequenos grupos é, pelo contrário, a de superar a relação hierárquica pela intimidade, ou que é capaz de subvertê-la." (1978: 85)

Ou seja, a relação hierárquica não se refere apenas à "tutela" ou ao mandonismo que é exercido pelo superior, mas pela proximidade e ligação constante e duradoura que os subordinados estabelece com ele, criando inclusive laços afetivos e de intimidade.

Evidentemente, a comprovação empírica dessa proposição requer uma pesquisa adicional com estruturação diferente, que permita analisar as sutilezas da execução das prerrogativas de papel, o que requer um acompanhamento do cotidiano do indivíduo. Além do mais, um arcabouço teórico que permita investigar a intimidade será necessário, o que aproxima a pesquisa da psicologia social ${ }^{271}$.

Dessa forma, o estudo da hierarquia abre novos horizontes, com os quais a limitação deste trabalho poderá ser complementada. Acreditamos que o presente trabalho possa contribuir fornecendo bases para os estudos nessa direção.

\footnotetext{
${ }^{271}$ Cf. Ridgeway; Walker (2001); Howard (2001).
} 


\section{Bibliografia de Referência}

ABEGGLEN, James C. The Japanese Factory. Salem, New Hampshire: Ayer Company, 1984 [1958].

AGUIAR, Neuma (org.). Hierarquias em Classes. Rio de Janeiro: Zahar Ed., 1974.

Allen, G.C. Economia Japonesa. RJ: Zahar, 1983.

AMI, Nobuya. Heiankyô Zôei to Kodai Ritsuryô Kokka (A Construção do Palácio Heian e o Antigo Estado Ritsuryô). Tóquio: Haniwa Shobo, 2011.

AMINO, Yoshihiko. Nihontowa Nanika (Reflexões sobre o Japão). 1a. Edição. História do Japão vol. 00. Tóquio: Kôdansha, 2000.

. Nihonronno Shiza (Uma perspectiva da Japonologia). Tóquio: Shôgakukan, 1994.

Nihon Shakai no Rekishi Jô (História da Sociedade Japonesa: Primeira parte). Tóquio: Iwanami Shoten, 1997a.

Nihon Shakai no Rekishi Chû (História da Sociedade Japonesa: Segunda parte). Tóquio: Iwanami Shoten, 1997b.

Nihon Shakai no Rekishi Ge (História da Sociedade Japonesa: Última parte). Tóquio: Iwanami Shoten, 1997c.

ANDERSON, Perry. Linhagens do Estado Absolutista. São Paulo: Brasiliense, 1985.

AOKI, Tamotsu. Nihon Bunkaron no Hen'yô - Sengo Nihon no Bunka to Identity (Transformação da Japonologia: cultura e identidade japonesa no pós-guerra). Tóquio: Chûô Kôronsha, 1990.

ARAKI, Hiroyuki. Nihonjinno Kôdôyôshiki (Padrão de Comportamento dos Japoneses). Tóquio: Kôdansha, 1973.

ARICHI, Toru. Kindai Nihon no Kazokukan - Meijihen (A Concepção de Família do Japão Moderno: era Meiji). Tóquio: Kobundo, 1977.

ARUGA, Kizaemon. Nihon Kazokuseido to Kosakuseido (O Sistema Familiar Japonês e Sistema de Pequena Produção). Tóquio: Kawadeshobo,1943.

Ie no Rekishi - sonota (História da Casa e outras). Coleção Aruga Kizaemon vol. 11. Tóquio: Miraisha, 1971.

ARUKA, Miwako. Kazokuno Tagenka to Oyakokankei (As Múltiplas Dimensões da Família e Relação Pais e Filhos). In: ARUKA, M.; SASAME, K (org.). Oyakokankei 
no Yukue (O Destino da Relação Pais e Filhos). P. 181-219. Tóquio: Keishoshobo, 2004.

BENEDICT, Ruth. O Crisântemo e a Espada. São Paulo: Perspectiva, 1972 [1967].

. Padrões de Cultura. Lisboa: Livros do Brasil, s.d.

BObBio, N.; MAtTeuCCI, N.; PASQUino, G. Dicionário de Política. 4ª ed. Brasília: Editora Universidade de Brasília, 1992.

BOURDIEU, Pierre. A Distinção: crítica social do julgamento. São Paulo: Edusp; Porto Alegre, RS: Zouk, 2008.

CONFÚCIO. Os Analectos. São Paulo: Martins Fontes, 2005.

COURDY, Jean-Claude. Banzai da Economia Japonesa. RJ: Record, 1982.

CROMPTON, Rosemary. Class and Stratification: an Introduction to current debates. 2a. ed. Cambridge: Polity Press, 1998.

DAHRENDORF, Ralf. As Classes e Seus Conflitos na Sociedade Industrial. Brasília: Ed. Unb, 1982.

DORTIER, Jean-F. (dir.). Dicionário de Ciências Humanas. São Paulo: Martins Fontes, 2010.

DURKHEIM, Émile. As Regras do Método Sociológico. São Paulo: Martins Fontes, $2^{a}$. ed., 1999.

EDGAR, A.; SEDGWICK, P. (orgs.) Teoria Cultural de A a Z: conceitos-chave para entender o mundo contemporâneo. São Paulo: Contexto, 2003.

ELIAS, Norbert; SCOTSON, John L. Os Estabelecidos e os Outsiders: Sociologia das relações de poder a partir de uma pequena comunidade. Rio de Janeiro: Jorge Zahar Ed., 2000.

ELIAS, Norbert. Introdução à Sociologia. Lisboa: Edições 70, 2008.

FIELD, Norma. In the Realm of a Dying Emperor. Pantheon Books, 1991.

FUJII, Joji. Tennô no Rekishi 05kan Tennô to Tenkabito (História do Imperador Vol. 05: o imperador e os governantes). Tóquio: Kodansha, 2011.

FUJITA MIRAI KEIEI KENKYUJO (FMKK). 21 Seiki Nihonjin no Ikikata Kenkyû

Hôkokusho II Shiryôhen Sarariman Ishikichôsa Hôkokusho (Pesquisa sobre o Modo de Vida dos Japoneses do Século XXI-Relatório II, Arquivo: Relatório sobre a Opinião de Assalariados). Tóquio: FMKK, 2001.97p.

FUJITA, Satoru. Tennô no Rekishi 06kan Edojidai no Tennô (História do Imperador Vol. 06: o imperador do período Edo). Tóquio: Kodansha, 2011. 
FUJITANI, Takashi. Shochô Tennôsei no Mirai ni tsuite (Sobre o Futuro do Sistema Imperial Simbólico). In: GLUCK, C. et al. Nihon wa Doko e Ikunoka (Para onde vai o Japão?). História do Japão vol. 25. Tóquio: Kôdansha, 2003.

FUKUSHIMA, Noriko. Chûseikôki no Zaichishakai to Shôensei (A Sociedade Local da Baixa Idade Média e o Sistema Shôen). Tóquio: Doseisha, 2011.

FUKUTAKE, Tadashi. The Japanese Social Structure: Its Evolution in the Modern Century. Tóquio: University of Tokyo Press, 1989.

FUNABIKI, Takeo. Nihonjinron Saikô (Reavaliação do Japonismo). Tóquio: Nihon Hôsô Shuppan Kyôkai, 2003.

FURUTA, Takehiko. Yomigaeru Himika-Nihonkoku wa itsu hajimatta ka (A Ressureição de Himika: quando o Japão se originou?). Quioto: Minerva, 2011.

GIDDENS, Anthony. A Constituição da Sociedade. São Paulo: Martins Fontes, 1989 [1984].

Estrutura de Classes das Sociedades Avançadas. Rio de Janeiro: Zahar, 1975.

Em Defesa da Sociologia: ensaios, interpretações e tréplicas. São Paulo: Ed. UNESP, 2001.

GOFFMAN, Erving. A Representação do Eu na Vida Cotidiana. Petrópolis: Vozes, 1975 .

GOODE, William J. World Revolution and Family Patterns. Nova Iorque: Free Press of Glencoe, 1963.

HAMAGUCHI, Eshun. "Awaino Bunka" to "Hitorino Bunka" (A "Cultura do "entre outros"” e a "Cultura do "só"”). Tóquio: Chisen, 2003.

HARA, Junsuke (org.). Nihon no Kaisô Shisutemu 1- Kindaikato Shakaikaisô (Sistema de Estratificação Social Japonês Vol. 1: Estratos Sociais e Modernidade). Tóquio: Tôkyô Daigaku Shuppankai, 2000.

HARA, Junsuke; SEIYAMA, Kazuo. Shakaikaisô - Yutakasa no nakano fubyôdô (Estratificação social: desigualdade na prosperidade). Tóquio: Tokyo Daigaku Shuppankai, 1999.

HASEGAWA, Koichi. Chôsa Rinri to Jûmin Kihon Daichô Etsuram Mondai (A Moralidade na Pesquisa e a Questão de Acesso ao Bando de Dados de Residentes). In: SHAKAI CHÔSASHI SHIKAKUNINTEI KIKÔ. Shakai to Chôsa Sôkangô (Sociedade e Pesquisa: ed. inaugural). Tóquio: Yuhikaku, 2008. 
HASEGAWA, Y. et al. Nihonshakai no Kisôkôzô - Ie, Dôzoku, Sonraku no Kenkyû (Estratificação da Sociedade Japonesa: estudos sobre a casa, parentes e aldeia). Quioto: Horitsubunkasha, 1991.

HASHIMOTO, Kenji. Gendai Nihonno Kaikyûkôzô

Riron - Hôhô - Keiryôbunseki (Estrutura de Classes do Japão Contemporâneo:

Teoria, Método e Análise Quantitativa). Tóquio: Tôshindô, 1999.

Kaikyûshakai - Gendai Nihon no Kakusa wo tou (Sociedade de Classes: investigando a desigualdade social do Japão contemporâneo). Tóquio: Kôdansha, 2006.

Atarashii Kaikyûshakai Atarashii Kaikyûtôsô (Nova Sociedade de Classes Nova Luta de Classes). Tóquio: Kôbunsha, 2007.

HATTORI, Yasuhiro. Nihonkigyô no Shinritekikeiyaku - Soshiki to Jûgyôin no

Miezaru Yakusoku (O Contrato Psicológico da Empresa Japonesa: compromisso invisível entre a organização e o funcionário). Tóquio: Hakutoushobou, 2011.

HAYASHIMA, Daisuke. Muromashi Bakufuron (Estudo sobre o Xogunato de Muromachi). Tóquio: Kodansha, 2010.

HIRANO, Sedi. Pré-capitalismo e Capitalismo. São Paulo: Hucitec, 1988.

Castas, Estamentos e Classes Sociais: introdução ao pensamento de Marx e Weber. Campinas: Ed. Unicamp, 2002.

HIRATA, Helena S. Sobre o "Modelo" Japonês: automatização, novas formas de organização e de relações de trabalho. SP: Edusp, 1993.

HIRAI, Shoko. Nihon no Kazoku to Raifu Kôsu (A Família Japonesa e Life Course). Quioto: Minerva shobo, 2008.

HIRAYAMA, Asaji. Ieshakaito Kojinshugi (A Sociedade de Linhagens e Individualismo). Tóquio: Nihon Keizai Shimbun, 1995.

HIROOKA, Yoshiyuki. Kyôiku no Seido to Rekishi (O Sistema Educacional e História). Quioto: Mineruva Shobo, 2007.

HOEBEL, E. Adamson; FROST, Everett L. Antropologia Cultural e Social. $2^{\mathrm{a}}$. edição. São Paulo: Ed. Cultrix, 1984.

HOWARD, Judith A. A Sociological Framework of Cognition. In: BRANAMAN, Ann (org.). Self and Society. Malden, USA: Blackwell Publishing, 2001.

IANNI, Octavio. Teorias de Estratificação Social. São Paulo: Companhia Editora Nacional, 1972. 
IKEGAMI, Hiroko. Toyotomiseiken to Edobakufu (O governo de Toyotomi e o regime de Edo). 1a. Edição. História do Japão vol. 15. Tóquio: Kôdansha, 2002.

INGLIS, D.; BONE, J. (org.). Social Stratification: Critical Concepts in Sociology.

Vol. I. Londres e Nova Iorque: Routledge, 2006.

INOUE, Tadashi. Sekentei no Kôzô (A Estrutura da Aparência Social). Tóquio: NHK, 1977.

ISHIDA, Hiroshi. Does class matter in Japan? Demographics of class structure and class mobility from a comparative perspective. In: ISHIDA, H.; SLATER, David H. (org.). Social Class in Contemporary Japan: Structures, sorting and strategies. Londres e Nova Iorque: Routledge, 2010.

IWAI, H.; KONDO, H. Gendai Kyôiku Shakaigaku (Sociologia da Educação Contemporânea). Tóquio: Yuhikaku, 2010.

IWAKAMI, M. et al. Ima kono Nihon no Kazoku - kizuna no yukue (Família japonesa do presente: perspectivas de laços). Tóquio: Koubundou: 2010.

JOHNSON, Allan G. Dicionário de Sociologia: guia prático da linguagem sociológica. Rio de Janeiro: Jorge Zahar, 1997.

JOHNSON, Chalmers A. MITI and the Japanese Miracle: the growth of industrial policy, 1925-1975. California: Stanford University Press, 1982.

KAJI, Nobuyuki. Jukyô towa Nanika (O que é confucionismo). Tóquio: Chuôkôronsha, 1990.

KANBAYASHI, Hiroshi. Chûryûishiki to Nihon Shakai - Kaisô Kizokuishiki no Jidaiteki Henka to sono Imi (A Identificação do Estrato Médio e Sociedade Japonesa: a transformação da identificação de posição social e seu significado). In: SEIYAMA, K. et al. Nihon no Shakaikaisô to sono Mekanizumu - fubyôdo o toinaosu (A estratificação social do Japão e seu mecanismo: rediscutindo a desigualdade). Tóquio: Hakutoushobou, 2011.

KATAOKA, Yoshimi. Kazoku no Teigizuke (A definição de família). In: NONOYAMA , H. (org.). Ronten Handobukku Kazokushakaigaku (Manual de Discussão Teórica: Sociologia da Família). Quioto: Sekaishisosha, 2009.

KAWAI, Takao. Kindai Nihon Shakaigaku no Tenkai - Gakumon-undô toshiteno Shakaigakuno Seidoka (Desenvolvimento da Moderna Sociologia Japonesa: institucionalização da Sociologia como movimento científico). Tóquio: Kouseisha, 2003. 
KAWAMURA, Lili. Para onde vão os brasileiros? Imigrantes brasileiros no Japão. Campinas, SP: Ed. da Unicamp, 1999.

KAWASE, Kazuma. Ashikagagakkô no Kenkyû (Estudo sobre a Escola Ashikaga). Tóquio: Kodansha, 1974.

KAWASHIMA, Takeyoshi. Hyôkato Hihan (Avaliação e Crítica). Minzokugakukenkyû (Pesquisas de Etnologia), Tóquio, v.14, n.4, p. 263-270, maio/1950.

KERBO, Harold R. Social Stratification. In: BRYANT, Clifton D.; PECK, Dennis L. (org.). Twenty-First Century Sociology: A Reference Handbook. Sage Publications, 2007.

KITANO, Seiichi. Ie to Dôzoku no Kisoriron (Teoria básica de Casa e Parentesco). Tóquio: Miraisha, 1976.

KIKKAWA, Toru. Kaikyû-Kaisô Ishiki no Keiryô Shakaigaku (Sociologia Quantitativa de Classe Social e Estrato). In: TODOROKI, M. 2005nen SSM Chôsa Shirizu 8 Kaisôishiki no Genzai (Série Pesquisa SSM 2005 vol. 8: A atualidade da consciência de classe). Sendai, Miyagi; Quioto: 2005nen SSM Chosa Kenkyukai, 2008.

KIKUCHI, Wataru. Pronomes Pessoais e Papéis Sociais: um estudo da sociedade japonesa sob a ótica da inter-relação língua e cultura. 2003. 142 p. Dissertação (Língua, Literatura e Cultura Japonesa) - FFLCH/USP, São Paulo.

.Papéis Sociais e a Dinâmica da Relação Interpessoal da Sociedade Japonesa.

Estudos Japoneses, São Paulo, n. 25, p. 81-95, 2005.

KOBAYASHI, Daisuke. Kaisô Kizoku Ishiki ni tsuite no Kiso Bunseki (The Effects of Employment Status on Class Consciousness). In: MIWA, S.; KOBAYASHI, D. (org). 2005nen SSM Nihon Chôsa no Kiso Bunseki - kôzô; sûsei; hôhô (Análise Básica da Pesquisa SSM 2005: estrutura, tendências e metodologia). Sendai, Miyagi: 2005nen SSM Chosa Kenkyukai, 2008.

KOCHI, S.; NITTA, I. Tennô no Rekishi 04kan Tennô to Chûsei no Buke (História do Imperador Vol. 04: o imperador e a família de guerreiros da Idade Média). Tóquio: Kodansha, 2011.

KOSAKA, Kenji. Shakaigaku ni okeru Fômaru Seori (Teoria Formal da Sociologia). Tóquio: Harvestsha, 2006.

KUMAGAI, Kimio. Daiô kara Tennô e (Transição do rei ao imperador). 1a. Edição. História do Japão vol. 03. Tóquio: Kôdansha, 2001. 
LEBARON, Frédéric. Sociologia de A a Z. Lisboa: Escolar Editora, 2010.

LITTLEJOHN, James. Estratificação Social: uma introdução. Rio de Janeiro: Zahar Ed., 1976.

LITWAK, E.; SZELENYI, I. Primary Group Structures and Their Functions: Kin, Neighbors, ands Friends. In: American Sociological Review, n. 34, p. 465-481, 1969.

LUHMANN, N. Introdução à Teoria dos Sistemas. Petrópolis, RJ: Vozes, 2009.

MAKINO, Jiro. Shinkaishahô no Kakushin - Nihongata Naibutôseimondai (A Essência da Nova Lei de Empresa: questão do modelo japonês de controle interno). Tóquio: Iwanamishoten, 2006.

MARSHALL. T.H. Cidadania, Classe Social e Status. Rio de Janeiro: Zahar, 1967 [1963].

MARUYAMA, Yumiko. Tennô Saishi no Hen'yô (A Transformação do Culto ao Imperador). OTSU, T. et. Al. Kodai Tennôsei o Kangaeru (Reflexões sobre o Antigo Sistema Imperial). História do Japão vol. 08. Tóquio: Kôdansha, 2001.

MARX, Karl. O Capital: crítica da economia política. Livro 3, vol. 6. Rio de Janeiro: Civilização Brasileira, 1968.

As Lutas de Classes na França (1848 a 1850). Rio de Janeiro: Editorial Vitória, 1956.

MARX, Karl; ENGELS, Friedrich. Manifesto do Partido Comunista. Petrópolis: Vozes, 1998.

MILIBAND, Ralph. Análise de classes. In: GIDDENS, A.; TURNER, J. (Org.). Teoria social hoje. São Paulo: Ed. Unesp, 1999.

MILLS, Theodore M. Sociologia dos Pequenos Grupos. São Paulo: Livraria Pioneira Editora, 1970 [1967].

MINAMI, Hiroshi. Nihonjinron Meijikara Konnichimade (Japonologia, da Era Meiji à Atualidade). Tóquio: Iwanami, 1994.

MITO, Tadashi. Ie toshiteno Nihonshakai (A Sociedade Japonesa como Casa). Tóquio: Yuhikaku, 1994.

MOCHIZUKI, S.; HARIMOTO, H.; OKAMYO H. (org.). Nihon no Kyôiku o Kangaeru - Genjô to Tembô (Reflexões sobre a Educação do Japão: realidade e perspectivas). Tóquio: Gakubunsha, 2010.

MORI, Kazuo. Nihon no Keiei (Administração Japonesa). Tóquio: Nihonkeizaishimbunsha, 2004. 
MORIKAWA, Terumichi. Zôhoban Kyôikuchokugo eno Michi-Kyôiku no Seijishi (A Trajetória para Diretrizes da Educação: a história política da educação. Versão revisada). Tóquio: Sangensha, 2011.

MUTA, Kazue. Senryaku toshiteno Kazoku-Kindai Nihon no Kokuminkokka Keisei to Josei (A Família como Estratégia: a formação do Estado nacional do Japão moderno e a figura da mulher). Tóquio: Shinyosha, 1996.

NAKAMURA, Toshio. Kurabu wo Toinaosu (Rediscutindo o "Clube"). In: NAKANISHI, T.; MORI, T. Nakamura Toshio Chosakushû Dai4kan BukatsuKuraburon (Coleção Obras de Nakamura Toshio Vol.4: discussão sobre a atividade de departamentos e “clubes”). Tóquio: Sobunkikaku, 2009.

NAKANE, Chie. Tateshakaino Ningenkankei (As Relações Pessoais na Sociedade Vertical). Tóquio: Kôdansha, 1967.

.Tekiôno Jôken (Condições de Adaptação). Tóquio: Kôdansha, 1972.

. Tateshakaino Rikigaku (O mecanismo da Sociedade Vertical). Tóquio: Kôdansha, 1978.

Kazoku o Chûshinto shita Ningenkankei (As Relações Pessoais centradas na Família). Tóquio: Kôdansha, 1977.

NARUSAWA, Akira. Gendai Nihon no Shakai Chitsujo - rekishiteki kigen o motomete (A Ordem Social do Japão Contemporâneo: na busca das origens históricas). Tóquio: Iwanami Shoten, 2011.

NHK HOSO BUNKA KENKYUJO. Gendai Nihonjin no Ishiki Kôzô - dai 7han (Estrutura de Opinião do Japonês Contemporâneo: $7^{\text {a }}$. edição). Tóquio: Nihon Hoso Shuppan Kyokai, 2010.

NIHON KEIEISHA DANTAI RENMEI (Nikkeiren). Shinjidai no Nihonteki Keiei Chôsensubeki Hôkô to sono Gutaisaku (Administração ao Estilo Japonês da Nova Era: desafios e medidas concretas). Tóquio: Nikkeiren, 1995.

NIHON RODO KENKYU KIKO (NRKK). Chôsa Kenkyû Hôkokusho No. 136 Furitâ no Ishiki to Jittai - 97nin eno Hiaringukekka yori (Relatório de Pesquisa No. 136 A Realidade e Consciência dos Freelancers: resultado de 97 entrevistas). Tóquio: NRKK, 2000. 672 p.

NIHON SHAKAIGAKKAI CHÔSA IINKAI. Nihonshakaino Dansôteki Kôzô (Estratificação Social da Sociedade Japonesa). Tóquio: Yûhikaku, 2002. 
NISHIYAMA, Matsunosuke. Iemoto no Kenkyû (Estudo sobre o Mestre). Nishiyama Matsunosuke Chosakushû, vol. 1. Tóquio: Yoshikawa Kobunkan, 1982.

NONOYAMA , H. (org.). Ronten Handobukku Kazokushakaigaku (Manual de Discussão Teórica: Sociologia da Família). Quioto: Sekaishisosha, 2009.

NOTO, Ken. Jômonjidai (Período Jômon). Tóquio: Kawade Shobo Shinsho, 2011.

OCHIAI, Emiko. Kindaikazoku no Magarikado (A Encruzilhada da Família Moderna). Tóquio: Kadokawashoten, 2000.

OGASAWARA, Shin. Nihon Shakaigakushi e no Izanai (Um convite à história da Sociologia Japonesa). Quioto: Sekai Shisôsha, 2000.

OGI, Naoki. Ai no Muchi toiu Sakkaku. Taibatsu wa eskarêto shi, kosodate no chikara o ushinawaseru (A Ilusão do "chicote do amor": o castigo físico recrudesce e elimina a capacidade de criar os filhos). In: Nihon no Ronten 2007 - The Issues for Japan 2007, p. 616-619. Tóquio: Bungei Shunju, 2006.

OGURA, S.; YAMAGUCHI, T. Tennô no Rekishi 09kan Tennô to Shûkyô (História do Imperador Vol. 09: o Imperador e a religião. Tóquio: Kodansha, 2011.

OKAMURA, Michio. Jômon no Seikatsushi (A vida do período Jômon): edição revisada. 1a. Edição. História do Japão vol. 01. Tóquio: Kôdansha, 2002.

OSUMI, Kiyoharu. Kunshin Chitsujo to Girei (A Hierarquia entre o Soberano e os Súditos e os Ritos). In: OTSU, T. et. Al. Kodai Tennôsei wo Kangaeru (Reflexões sobre o Antigo Sistema Imperial). História do Japão vol. 08. Tóquio: Kôdansha, 2001.

OTSU, Toru. Tennô no Rekishi 01kan Shinwa kara Rekishi e (História do Imperador Vol. 01: da mitologia à história. Tóquio: Kodansha, 2010.

OUThwaite, W.; BOtTomore, T. (org.). Dicionário do Pensamento Social do Século XX. Rio de Janeiro: Jorge Zahar Ed., 1996.

PARSONS, Talcott. EI Sistema Social. Madrid: Revista de Occidente, 1966.

PARSONS, T.; BALES, R. Familiy, Socialization and Interaction Process. Glencoe, Ill.: Free Press, 1955.

POULANTZAS, Nicos. Classes Sociais no Capitalismo de Hoje. Rio de Janeiro: Zahar, 1975.

A Nova Pequena Burguesia. In: HUNT, A. Classes e Estrutura das Classes. Lisboa: Edições 70, 1982.

RIDGEWAY, Cecilia L.; WALKER, Henry A. Status Structures. In: BRANAMAN, Ann (org.). Self and Society. Malden, USA: Blackwell Publishing, 2001. 
SAKAUE, Yasutoshi. Ritsuryôkokka no Tenkan to "Nihon" (A Transição do Estado Ritsuryô e o “Japão”). 1a. Edição. História do Japão vol. 05. Tóquio: Kôdansha, 2001.

SAKURAI, Célia. Os Japoneses. São Paulo: Contexto, 2007.

SAKUTA, Keiichi. Hajino Bunka Saikô (Revisão da Cultura da Vergonha). Tóquio: Chikumashobô, 1967.

SANSOM, G. B. Japan: a Short Cultural History. 10ª ed. Tóquio: Charles E. Tuttle Company, 1987.

SATO, M. et al. Shôsetsu Nihonshi Kenkyû (Estudo detalhado da História do Japão). Tóquio: Yamakawa, 2008.

SATO, Y.; OJIMA, F. Gendai no Kaisô Shakai 1 - Kakusa to Tayôsei (Sociedade Estratificada Contemporânea 1: desigualdade e diversidade). Tóquio: Tokyo Daigaku Shuppankai, 2011.

SCOTT, John. Stratification and Power: structures of class, status and command. Cambridge, UK: Polity Press, 2004.

SCOTT, John (org.). Class: Critical Concepts. Londres e Nova Iorque: Routledge, 1996.

SEIYAMA, Kazuo (org.). Nihon no Kaisô Shisutemu 4- Jendâ • Shijô • Kazoku (Sistema de Estratificação Social Japonês Vol. 4: Gênero, Mercado e Família). Tóquio: Tôkyô Daigaku Shuppankai, 2000.

Byôdô no Rinen to Mekanizumu - jisshô wo koeta kaisô kenkyû ni mukete (A Filosofia e o Mecanismo da Igualdade: para uma pesquisa de estratificação além da empiria). In: SEIYAMA, K. et al. Nihon no Shakaikaisô to sono Mekanizumu fubyôdo o toinaosu (A estratificação social do Japão e seu mecanismo: rediscutindo a desigualdade). Tóquio: Hakutoushobou, 2011.

Shakaichôsa ni totte hontô no kadai wa nanika (Qual é o verdadeiro desafio para a pesquisa social). In: SHAKAI CHÔSASHI SHIKAKUNINTEI KIKÔ. Shakai to Chôsa Sôkangô (Sociedade e Pesquisa: ed. inaugural). Tóquio: Yuhikaku, 2008.

SEIYAMA, K. et al. Nihon no Shakaikaisô to sono Mekanizumu - fubyôdo o toinaosu (A estratificação social do Japão e seu mecanismo: rediscutindo a desigualdade). Tóquio: Hakutoushobou, 2011.

SENDA, Yuki. Nihongatakindaikazoku - Dokokara kite doko e ikunoka (Família moderna japonesa: de onde veio e para onde vai). Tóquio: Keisoshobo, 2011. 
STAVENHAGEN, Rodolfo. Estratificação Social e Estrutura de Classes. In: BERTELLI, et al. Estrutura de Classes e Estratificação Social. Rio de Janeiro: Zahar Ed., 1966.

SUDO, Naoki. Nihonjin no Kaisô Ishiki (A Identificação de Posição Social dos Japoneses). Tóquio: Kodansha, 2010.

SUGAWARA, Masako. Chûsei no Buke to Kuge no "Ie" (A Família de Guerreiros e “Casa" da Nobreza da Idade Média). Tóquio: Yoshikawa Kobunkan, 2007.

SUGIMOTO, Y.; MOUER, R. Nihonjin wa Nihonteki ka (Seriam os japoneses nipônicos?). Tóquio: Toyo Keizai Shimposha, 1982.

SUZUKI, Tae. Cultura e Sociedade Japonesa: da época primitiva às origens do Estado. Estudos Japoneses, São Paulo, n.23, p. 75-90, 2003.

TAKAGI, Shingen. Kûkai-Shôgai to sono Shûhen(Kûkai: trajetória de vida e afins). Tóquio: Yoshikawa Kobunkan, 2009.

TAKAHASHI, Katsunori et al. Fukigen na Shokuba - Naze Shaindôshi de Kyôryoku dekinainoka (Local de trabalho mal humorado: por que os funcionários não cooperam?). Tóquio: Kodansha, 2008.

TAKAHASHI, Nobuo. Kyomô no Seikashugi - Nihongata Nenkôsei Fukkatsu no Susume (O Delírio da Avaliação por Resultados: em defesa do retorno do modelo japonês de tempo de serviço). Tóquio: Nikkei BPsha, 2004.

TAKANO, Yôtarô. "Shûdanshugi”" toiu Sakkaku- Nihonjinronno omoichigaito sono yurai (Uma ilusão denominada "coletivismo": as causas de equívoco do japonismo). Tóquio: Shin'yôsha, 2008.

TAKASE, Hiroi. Tennôke no Rekishi (História da Família Imperial). Tóquio: Kawade Shobo Shinsho, 2005).

TAKESUE, J.; MORIOKA, H.; SHITARA, H. Yayoijidai (Período Yayoi). Tóquio: Kawade Shobo Shinsho, 2011.

TAKEUCHI, Yasuo. Nihonjinno Kôdô Bumpô (As Regras de Comportamento dos Japoneses). Tóquio: Tôyôkeizai Shimpôsha, 1995.

TANAKA, Hiroki. Chûseibushidan no Kôzô no Kenkyû (Estudo sobre os Guerreiros da Idade Média). Tóquio: Azekura Shobo, 2011.

TERAKI, Nobuaki. Kinseimibun to Hisabetsumin no Shosô (Os Aspectos de Status da Era Pré-moderna e o Povo Discriminado). Osaka: Kaiho Shuppansha, 2000. 
TERASAWA, Kaoru. Ôkentanjô (O nascimento da dinastia). 1a. Edição. História do Japão vol. 02. Tóquio: Kôdansha, 2000.

TODA, Teizo. Kazokukôsei (Estrutura Familiar). Tóquio: Shinsensha, 2001 [1937].

TOMINAGA, Kenichi. Nihon no Kindaika to Shakaihendô (A Modernização do Japão e Mudança Social). Tóquio: Kodansha, 1990.

TOTSUKA, Hiroshi. Taibatsu ga Kodomo o Yomigaeraseru - seizensetsu ni motozuku waga yotto sukûru no tokuiku (O castigo físico ressuscita a criança: a educação da nossa escola de iatismo que se baseia no princípio da bondade dos humanos). In: Nihon no Ronten 2007 - The Issues for Japan 2007, p. 616-619. Tóquio: Bungei Shunju, 2006. TSUCHIYA, Motonori. Gendaikyôikuseidoron (Teoria do Sistema Educacional Contemporâneo). Quioto: Minervashobo, 2011.

TSUDA, Sokichi. "Kiku to Katana” no kuni - Gaikokujinno Nihonkan ni tsuite (O país do "Crisântemo e a Espada": Sobre a visão nipônica dos estrangeiros). In: TSUDA, Sokichi. Tsuda Sokichi Zenshû (Coleção Tsuda Sokichi). v. 21.Tóquio: Iwanamishoten, 1988.

UEHARA, Alexandre R. Política Externa do Japão: mudança ou continuidade? (1985-1998). 2001. 309 f. Tese (Doutorado em Ciência Política) - FFLCH/USP, São Paulo, 2001.

UEJIMA, Susumu. Chûsei Ôken no Sôshutsu to Insei (A Criação da Realeza da Idade Média e Insei). In: OTSU, T. et. Al. Kodai Tennôsei o Kangaeru (Reflexões sobre o Antigo Sistema Imperial). História do Japão vol. 08. Tóquio: Kôdansha, 2001.

UENO, Chizuko. Kindaikazoku no Seiritsu to Shûen (A formação e o fim da Família Moderna). Tóquio: Iwanamishoten, 1994.

VARLEY, Paul. Japanese Culture. $4^{\mathrm{a}}$ ed. Honolulu: University of Hawai'i Press, 2000.

VOGEL, Ezra F. Japan as Number One: lessons for America. San Jose, Nova Iorque, Lincoln, Shanghai: iUniverse, 2001.

WAKABAYASHI, Naoki. Network Organizations: New Vision from Social Network Perspective. Tóquio: Yuhikaku, 2009.

WATANABE, Akihiro. Heijôkyô to Mokkan no Seiki (O Século da Capital Heijô). 1a. Edição. História do Japão vol. 04. Tóquio: Kôdansha, 2001.

WEBER, Max. Ensaios de Sociologia. Rio de Janeiro: Zahar, 1982.

Economia e Sociedade. Vol. 1. Brasília, DF: Ed. UnB, 2000. 
Economia e Sociedade. Vol. 2. Brasília, DF: Ed. UnB, 1999.

WOLFEREN, K. van. The Enigma of Japanese Power. Vol. 2. Tóquio: Hayakawa, 1990.

WRIGHT, Erik Olin. Classe, Crise e o Estado. Rio de Janeiro: Zahar, 1981.

Classes. Londres, Verso: 1985.

YAMADA, Masahiro. Meisôsuru Kazoku - Sengokazokumoderu no Keisei to Kaitai (Família Perdida: constituição e declínio do modelo de família do pós-guerra). Tóquio: Yuhikaku, 2005.

YAMAGUCHI, Miwa. Nihon Kigyô ni okeru "Wa" no Kinô (A Função da "Harmonia" nas Empresas Japonesas). Fukita, Osaka: Osaka Daigaku Shuppankai, 2010.

YAMASHITA, Hiroshi. Nihonjin no Shinri, Kôdômoderu to Nihonkigyô no Kuorithi (O Aspecto Psicológico dos Japoneses, Modelo de Conduta e Qualidade das Empresas Japonesas). Tóquio: Hakutoshobo, 2010.

YASUDA, Hiroshi. Kindai Tennôsei Kokka no Rekishiteki Ichi (A Posição Histórica do Estado Imperial Moderno). Tóquio: Otsuki Shoten, 2011.

YASUMOTO, Biten. Yamatochôtei no Kigen - Yamataikoku no Tôsen to JinmuTôsei Denshô (A Origem da Corte de Yamato: a transferência para Leste do Reino de Yamatai e possibilidade do domínio de Jinmu na região). Tóquio: Benshi Shuppan, 2005.

YAZAWA, S.; TENDO, M. Kodomo no Shakaika to Oyakokankei (A Socialização dos Filhos e Relação Pais e Filhos). In: ARUKA, M.; SASAME, K (org.). Oyakokankei no Yukue (O Destino da Relação Pais e Filhos). P. 68-106. Tóquio: Keishoshobo, 2004.

YONEYAMA, Toshinao. Nihonjinno Nakamaishiki (A Concepção de Coleguismo dos Japoneses). Tóquio: Kôdansha, 1976.

YOSHIDA, Takashi. Nihon no Tanjô (Nascimento do Japão). Tóquio: Iwanami Shoten, 1997.

YOSHIKAWA, Shinji. Tennô no Rekishi 02kan Shômu Tennô to Butto Heijôkyô (História do Imperador Vol. 02: o imperador Shômu e a capital budista Heijôkyô). Tóquio: Kodansha, 2011. 


\section{Bibliografia consultada}

BENDIX, Reinhard (org.). Class, Status and Power: social stratification in comparative perspective. Nova Iorque: Free Press, 1966.

BERNARDI, Fabrizio; GONZÁLEZ, Juan J.; REQUENA, Miguel. The Sociology of Social Structure. In: BRYANT, Clifton D.; PECK, Dennis L. (org.). Twenty-First Century Sociology: A Reference Handbook. Sage Publications, 2007.

BOTTOMORE, T. B. As Classes na Sociedade Moderna. Rio de Janeiro: Zahar, 1968. BOTTOMORE, Tom; NISBET, Robert. História da Análise Sociológica. Rio de Janeiro, Zahar, 1980.

BURKE, Peter. Sociologia e História. Porto: Afrontamento, 2ª ed., 1980.

História e Teoria Social. São Paulo: Unesp, 2002.

COMBESSIE, Jean-Claude. O Método em Sociologia. São Paulo: Ed. Loyola, 2004.

DOMINGUES, José Maurício. Ensaios de Sociologia: teoria e pesquisa. Belo Horizonte: Ed. UFMG, 2004.

DURKHEIM, Émile. Da Divisão do Trabalho Social. São Paulo: Martins Fontes, $2^{\mathrm{a}}$. ed., 1999.

As Formas Elementares de Vida Religiosa: o sistema totêmico na Austrália. São Paulo: Ed. Paulinas, 1989.

ELIAS, Norbert. O Processo Civilizador. 2v. Rio de Janeiro: Jorge Zahar Ed., 1994.

A Sociedade dos Indivíduos. Rio de Janeiro: Jorge Zahar Ed., 1994.

FAISON, Elyssa. Managing Women : Disciplining Labor in Modern Japan. Berkeley; Los Angeles; Londres: Univ. of California Press, 2007.

FUJIMI, S.; NISHINO, M. (org.). Gendainihonjin no Kazoku (Padrões de Família do Japão Contemporâneo). Tóquio: Yuhikaku, 2009.

FUKUTAKE, Tadashi. Nihonnôson no Shakaitekiseikaku - Nihon no Nôsonshakai (A Característica Social da Zona Rural Japonesa /A Sociedade Rural do Japão). Tóquio: University of Tokyo Press, 1976 [1949].

GIDDENS, Anthony. Central Problems in Social Theory: Action, structure and contradiction in social analysis. Londres: Macmillan Press, 1979.

GIDDENS, Anthony; TURNER, Jonathan (Org.). Teoria social hoje. São Paulo: Ed. Unesp, 1999. 
GUBRIUM, J.F.; HOLSTEIN, J.A. What is Family? Mountain View, CA: Mayfield Publishing Company, 1990.

HAMAGUCHI, Eshun. Nihon Kenkyû Genron - Kankeitai toshiteno Nihonjin to Nihon Shakai (Teoria de Estudos do Japão: os japoneses e a sociedade japonesa como correlação). Tóquio: Yuhikaku, 1998.

HARA, Junsuke. Shokugyô keireki no Bunseki (Análise da trajetória profissional). In: TOMINAGA, Kenichi. Nihon no Kaisôkôzô (Estrutura da estratificação do Japão). Tóquio: Tokyo Daigaku Shuppankai, 1979.

HARA, Junsuke; ASAKAWA, Tatsuto. Shakaichôsa (Pesquisa social). Tóquio: Hôso Daigaku Kyôiku Shinkôkai, 2005.

HIRAI, Shoko. Ie Seido (O Sistema Casa). In: NONOYAMA , H. (org.). Ronten Handobukku Kazokushakaigaku (Manual de Discussão Teórica: Sociologia da Família). Quioto: Sekaishisosha, 2009.

HUNT, A. Classes e Estrutura das Classes. Lisboa: Edições 70, 1982.

IIDA, Tetsuya. Gendai Nihon Shakairon (Teoria Sociológica Japonesa Contemporânea). Tóquio: Gakubunsha, 2008.

IKEGAMI, Tomoko; ISHIDA, Yasuhiko. Status Hierarchy and the Role of Disidentification in Discriminatory Perception of Outgroups. Japanese Psychological Research, vol. 49, n.2, p. 136-147, 2007.

INABA, Tsuguharu. Nihon Kinsei Shakai Keiseishiron (História da Formação da Sociedade Pré-moderna Japonesa). Tóquio: Azekura Shobo, 2009.

INOUE, Katsuo. Kaikaku to Bakumatsuhenkaku (Reformas e as Mudanças no final do Xogunato). 1a. Edição. História do Japão vol. 18. Tóquio: Kôdansha, 2002.

INOUE, Mariko (org.). Kazokushakaigaku wo Manabuhito no tameni (Para os estudiosos da sociologia da família). Quioto: Sekaishisosha, 2010.

ISHIDA, Eiichirô. Nihombunkaron (Teoria da Cultura Japonesa). 9a . ed. Tóquio: Chikuma Shobô, 1971. [1969]

ISHIDA, Hiroshi. Shakaiteki Fubyôdô to Kaisô Ishiki no Kokusai Hikaku (Social Inequality and Status Consciousness in Cross-national Comparative Perspective). In: OSAKA SHOGYO DAIGAKU HIKAKU CHIIKI KENKYUJO; TOKYO DAIGAKU SHAKAIGAKU KENKYUJO (org.). JGSS de mita Nihonjin no Ishiki to Kôdô (A Consciência e Ação dos Japoneses pela pesquisa JGSS). Tóquio: Tokyo Daigaku Shakaigaku Kenkyujo, 2004. 
KAKEHI. Masahiro. Môkoshûrai to Tokuseirei (O ataque dos mongóis e estado de exceção). 1a. Edição. História do Japão vol. 10. Tóquio: Kôdansha, 2001.

KAWAMOTO, Akira. Nihonjin to Shûdanshugi (Os japoneses e o coletivismo). Tóquio: Tamagawa University, 1982.

KIDA, Minoru. Nippon Buraku (Aldeia japonesa). Tóquio: Iwanamishinsho, 1979.

KITO, Hiroshi. Bunmei toshiteno Edo shisutemu (O sistema de Edo e a Civilização). 1a. Edição. História do Japão vol. 19. Tóquio: Kôdansha, 2002.

KIKUCHI, W. Sociedade Japonesa: Base estrutural das relações sociais. Estudos Japoneses, São Paulo, n. 24, p. 107-124, 2004.

KOSAKA, K. (org.). Social Stratification in Contemporary Japan. Kegan Paul International, 1994.

KONDO, Hiroyuki (org.). Nihon no Kaisô Shisutemu 3 - Sengo Nihonno Kyôikushakai (Sistema de Estratificação Social Japonês Vol. 3: Sociedade e Educação do Pós-guerra). Tóquio: Tôkyô Daigaku Shuppankai, 2000.

KURUSHIMA, Noriko. Ikki to Sengokudaimyô (O levante dos camponeses e os senhores feudais). 1a. Edição. História do Japão vol. 13. Tóquio: Kôdansha, 2001.

LEVI, Jean. Confucio. Madri: Editorial Trotta, 2005.

LUMMIS, Charles D. A New Look at the Chrysanthemum and the Sword. Tóquio: Shohakusha, 1983.

MANIWA, Mitsuyuki. Nihontekishûdan no shakaigaku-hôsetsu to haiso no kôzô. (A sociologia da coletividade japonesa: estrutura de incorporação e exclusão). Tóquio: Kawadeshobô, 1990.

MARTINEZ, D. P. Modern Japanese Culture and Society. Londres e Nova Iorque: Routledge, 2007.

MASAMURA, Toshiyuki. Himitsuto Haji (Segredo e Vergonha). Tóquio: Keisôshobô, 1995.

MEAD, George H., Mind, Self \& Society, Chicago: The University of Chicago Press, 1952.

MILIBAND, Ralph. O Estado na Sociedade Capitalista. Rio de Janeiro: Zahar, 1972.

MURDOCK, George P. Social Structure. Nova Iorque: Macmillan, 1949.

NAKAMURA, Hideshige. Ritsuryôkokkato Ie (O Estado de Código Civil e Penal e a Casa). In: SAEKI ARIKIYOSENSEI KOKI KINENKAI. Nihonkodaino Shakaito Seiji (A Sociedade e Política no Japão Antigo). Tóquio: Yoshikawa Kobunkan, 1995. 
MORITA, Tei. Tenji Tennô to Taika no Kaishin (O Imperador Tenji e a Reforma de Taika). Tóquio: Doseisha, 2009.

NAKAMURA, Tomokazu. Nihon Kodai no Shiseisei (O Sistema de Clãs do Japão Antigo). Tóquio: Yagi Shoten, 2009.

NAKANE, Chie. Japanese Society. California: University of California Press, 1984 [1970].

NISHIKAWA, Makoto. Tennô no Rekishi 07kan Meiji Tennô no Dainippon

Teikoku (História do Imperador Vol. 07: O Grande Império Japonês do Imperador Meiji. Tóquio: Kodansha, 2011.

NITTA, Ichiro. Taiheiki no Jidai (A era de Taiheiki). 1a. Edição. História do Japão vol. 11. Tóquio: Kôdansha, 2001.

ORTIZ, Renato. O Próximo e o Distante, Japão e Modernidade - Mundo. São Paulo: Brasiliense, 2000.

OSSOWSKI, Stanislaw. Estrutura de Classes na Consciência Social. Rio de Janeiro: Zahar, 1964.

ÔTSU, T.; ÔSUMI, K.; SEKI, K. et al. Kodaitennôsei o kangaeru (Análise do Regime Imperial da Antiguidade). 1a. Edição. História do Japão vol. 08. Tóquio: Kôdansha, 2001.

OTSU, Toru. Michinaga to Kyûteishakai (Michinaga e a classe nobreza). 1a. Edição. História do Japão vol. 06. Tóquio: Kôdansha, 2001.

PARKIN, Frank. Estratificação Social. In: Bottomore, T.; Nisbet, R. História da Análise Sociológica. Rio de Janeiro: Zahar, 1980.

RAJKAI, Zsombor Tibor. Kazokuno Hikakubunkaron (Discussão cultural comparativa sobre a família). In: INOUE, Mariko. Kazokushakaigaku wo Manabuhito no tameni (Para os estudiosos da sociologia da família). Quioto: Sekaishisosha, 2010.

ROBERSON, James E. Japanese Working Class Lives: An Ethnographic Study of Factory. Londres e Nova Iorque: Routledge, 1998.

ROHLEN, Thomas P. Japan's High Schools. Berkeley, Los Angels e Londres: University of California Press, 1983.

SAKURAI, Eiji. Muromachibito no Seishin (O espírito dos homens de Muromachi). 1a. Edição. História do Japão vol. 12. Tóquio: Kôdansha, 2001. 
SATO, Hiroyuki. Kinseidaimyô no Kenryokuhensei to Ieishiki (A Organização de Poder dos Daimios da Era Kinsei e a Consciência de Casa). Tóquio: Yoshikawakobunkan, 2010.

SATO, Yoshimichi; ARITA, Shin. Impact f Globalization on Social Mobility in Japan and Korea: Focusing on Middle Classes in Fluid Societies. International Journal of Japanese Sociology, n.13, 2004.

SHIMOMUKAI, Tatsuhiko. Bushino Seichô to Insei (O desenvolvimento da classe dos guerreiros). 1a. Edição. História do Japão vol. 00. Tóquio: Kôdansha, 2001.

SHOJI, Kôkichi. Nihon Shakaigakuno Chôsen - henkakuwo yomitoku kenkyûto bunken (Desafios da Sociologia Japonesa: pesquisas e bibliografias que desvendam a mudança). Tóquio: Yûhikaku, 2002.

SINGLY, François de. Sociologia da Família Contemporânea. Rio de Janeiro: Ed. FGV, 2007.

SUGIMOTO, Yoshio. An Introduction to Japanese Society. Nova Iorque: Cambridge University Press, 2003.

SUMITANI, Kazuhiko. Nihonjin no Ishiki-Shisô ni okeru Ningen no Kenkyû (A consciência dos japoneses: um estudo sobre o pensamento). Tóquio: Iwanami, 1982.

SUZUKI, Jun. Ishin no Kôso to Tenkai (Os Propósitos e a Efetivação da Restauração Meiji). 1a. Edição. História do Japão vol. 20. Tóquio: Kôdansha, 2002.

TERASAWA, Masaharu. Nihonjin no Seishinkôzô - Dentô to Genzai (A Estrutura Espiritual dos Japoneses: tradição e atualidade). Quioto: Koyoshobo, 2002.

TÖNNIES, Ferdinand. Comunidad y Asociación. Barcelona: Ediciones Península, 1979.

Estates and Classes. In: SCOTT, John (org.). Class: Critical Concepts. Londres e Nova Iorque: Routledge, 1996.

TURNER, Bryan S. Status. Lisboa: Estampa, 1989.

TURNER, Jonathan H. Societal Stratification: A Theoretical Analysis. Nova Iorque: Columbia University Press, 1984.

UEDA, Masaaki. Nihon Kodai Kokka Ronkyû (Estudo sobre a Teoria do Estado do Japão Antigo). Tóquio: Hanawashobo, 1968.

UMINO, Michio (org.). Nihon no Kaisô Shisutemu 2- Kôheikanto Seijiishiki (Sistema de Estratificação Social Japonês Vol. 2: Senso de igualdade e Consciência Política). Tóquio: Tôkyô Daigaku Shuppankai, 2000. 
WIESE, Leopold von. Sociologia: Historia y Principales Problemas. Barcelona: Labor, 1932.

YAGI, Kosuke. Burakumondai no Shakaigaku (Sociologia dos Discriminados). In: KURIHARA, Akira (org.). Kôza Sabetsu no Shakaigaku Dai 2kan - Nihonshakai no Sabetsukôzô (Curso Sociologia da Discriminação vol. 2: a estrutura de discriminação da sociedade japonesa). Tóquio: Koubundou, 1996.

YAMAMOTO, Kôji. Yoritomo no Tenkasôsô (A fundação da sociedade por Yoritomo). 1a. Edição. História do Japão vol. 09. Tóquio: Kôdansha, 2001.

.O Papel Social da Ofensa Verbal no Japão. Estudos Japoneses. São Paulo, No. 22, p. 59-70, 2002.

YAMAMOTO, Shichihei. Nihonjin to soshiki (Os japoneses e a instituição). Tóquio: Kadokawa, 2007.

YOKOTA, FUYUHIKO. Tenkataihei (Sociedade Estabilizada). 1a. Edição. História do Japão vol. 16. Tóquio: Kôdansha, 2002.

YOSHIDA, Nobuyuki. Seijuku suru Edo (O Amadurecimento da Capital Edo). 1a. Edição. História do Japão vol. 17. Tóquio: Kôdansha, 2002. 
Anexos 


\section{Descrição da pesquisa de campo}

1- Objetivo: verificar a consciência dos japoneses no que se refere à hierarquia social, procurando complementar na forma de teste as proposições do referencial teórico nos quesitos: família (casal, filhos, irmãos), trabalho (relação com o superior, subordinados, desempenho), renda, escolaridade, status social, gênero, relação "veteranos" e "novatos", idade e hierarquia no imaginário social.

2- Período: 24 e 29 de julho; 13 a 25 de agosto; 9 de outubro a 4 de novembro; 17 de novembro de 2011.

3- Local de coleta de dados, com as respectivas províncias (entre parênteses): capital Tóquio e cidades de Fukushima (Fukushima), Yamagata (Yamagata), Hiraizumi (Iwate), Hakodate (Hokkaido), Sapporo (Hokkaido), Yokohama (Kanagawa), Urawa (Saitama), Kanazawa (Ishikawa), Nagoya (Aichi), Osaka (Osaka), Miyazu (Kyoto), Otsu (Shiga), Nara (Nara), Matsue (Shimane), Izumo (Shimane), Hiroshima (Hiroshima), Fukuoka (Fukuoka), Nagasaki (Nagasaki), Matsuyama (Ehime), Kochi (Kochi ) e Naha (Okinawa), todas no Japão.

4- Órgãos públicos que colaboraram com a pesquisa:

Centro de Intercâmbio Internacional da Província de Yamagata; Associação Comunitária de Yamagata; Centro Comercial e Industrial de Hiraizumi; Prefeitura de Hakodate; Prefeitura de Sapporo; Prefeitura de Kanazawa; Prefeitura de Osaka; Prefeitura de Nagoya; Associação Comunitária de Otsu; Associação Comunitária de Izumo; Centro Comunitário de Matsue; Espaço de Intercâmbio de Cidadãos de 
Hiroshima; Centro Comunitário de Fukuoka; Centro de Atividades Comunitárias de Nagasaki; Centro Comunitário de Matsuyama; Centro de Auxílio às Atividades Comunitárias de Saitama.

5- Método de coleta de dados: questionário e entrevista

6- Informantes: homens e mulheres de 20 a 69 anos, residentes na região metropolitana, que tenham ocupação ou alguma experiência profissional.

7-Perfil dos informantes

7.1-Gênero

\begin{tabular}{|l|c|c|c|}
\hline & masculino & feminino & total \\
\hline número de pessoas & 44 & 37 & 81 \\
\hline$\%$ & 54,3 & 45,7 & 100 \\
\hline
\end{tabular}

7.2- Faixa Etária

\begin{tabular}{|c|c|c|c|c|c|c|}
\hline & $\mathbf{2 0 - 2 9}$ & $\mathbf{3 0 - 3 9}$ & $\mathbf{4 0 - 4 9}$ & $\mathbf{5 0 - 5 9}$ & $\mathbf{6 0 - 6 9}$ & total \\
\hline No. & 11 & 18 & 24 & 18 & 10 & 81 \\
\hline$\%$ & 13,6 & 22,2 & 29,6 & 22,2 & 12,4 & 100 \\
\hline
\end{tabular}


7.3- Gênero por faixa etária

\begin{tabular}{|l|c|c|c|c|c|c|}
\hline & $\mathbf{2 0 - 2 9}$ & $\mathbf{3 0 - 3 9}$ & $\mathbf{4 0 - 4 9}$ & $\mathbf{5 0 - 5 9}$ & $\mathbf{6 0 - 6 9}$ & total \\
\hline masculino & 6 & 11 & 13 & 8 & 6 & 44 \\
\hline feminino & 5 & 7 & 11 & 10 & 4 & 37 \\
\hline total & 11 & 18 & 24 & 18 & 10 & 81 \\
\hline$\%$ & 13,6 & 22,2 & 29,6 & 22,2 & 12,3 & 100 \\
\hline
\end{tabular}

7.4- Estado Civil

\begin{tabular}{|c|c|c|c|c|}
\hline & solteiro & casado & s/inf. & total \\
\hline No. & 15 & 64 & 2 & 81 \\
\hline$\%$ & 18,5 & 79,0 & 2,5 & 100 \\
\hline
\end{tabular}

7.5- Escolaridade

\begin{tabular}{|l|c|c|l|l|l|l|l|}
\hline & Superior & Ensino & Escola & Superior & Pós- & Sem & Total \\
completo & médio & técnica & curto & graduação & inform. & \\
\hline No. & 36 & 32 & 6 & 4 & 1 & 2 & 81 \\
\hline$\%$ & 44,4 & 39,5 & 7,4 & 4,9 & 1,3 & 2,5 & 100 \\
\hline
\end{tabular}


7.6- Ocupação

\begin{tabular}{|l|c|c|}
\hline \multicolumn{1}{|c|}{ categorias } & No. & \% \\
\hline Func. Público & 27 & 33,4 \\
\hline Empreg. de firma & 13 & 16,0 \\
\hline Autônomo & 5 & 6,2 \\
\hline Meio-período ${ }^{273}$ & 4 & 5,0 \\
\hline Serviços & 6 & 7,4 \\
\hline Escritório & 3 & 3,7 \\
\hline Enfermeira & 2 & 2,5 \\
\hline Dona-de-casa & 4 & 5,0 \\
\hline Ativ. Artística & 2 & 2,5 \\
\hline Engenheiro & 1 & 1,2 \\
\hline Serviço social & 1 & 1,2 \\
\hline Jornalista & 1 & 1,2 \\
\hline Professor & 1 & 1,2 \\
\hline Cozinheiro & 1 & 1,2 \\
\hline Motorista de táxi & 1 & 1,2 \\
\hline Faxineiro & 1 & 1,2 \\
\hline Freelancer & 1 & 1,2 \\
\hline Sem ocupação & 5 & 6,2 \\
\hline S/ inf. & 2 & 2,5 \\
\hline Total & 81 & 100 \\
\hline & & \\
\hline & & \\
\hline
\end{tabular}

7.7- Número de irmãos

\begin{tabular}{|c|c|c|c|c|c|c|c|c|c|}
\hline irmãos & $\mathbf{0}$ & $\mathbf{1}$ & $\mathbf{2}$ & $\mathbf{3}$ & $\mathbf{4}$ & $\mathbf{5}$ & $\mathbf{6}$ & s/inf. & total \\
\hline No. & 6 & 42 & 20 & 4 & 4 & 3 & 1 & 1 & 81 \\
\hline $\boldsymbol{\%}$ & 7,4 & 51,9 & 24,7 & 4,9 & 4,9 & 3,7 & 1,2 & 1,2 & 100 \\
\hline
\end{tabular}

7.8- Coabitação

\begin{tabular}{|c|c|c|c|c|c|c|c|c|c|}
\hline moradores & $\mathbf{0}$ & $\mathbf{1}$ & $\mathbf{2}$ & $\mathbf{3}$ & $\mathbf{4}$ & $\mathbf{5}$ & $\mathbf{6}$ & s/inf. & total \\
\hline No. & 7 & 21 & 20 & 17 & 9 & 3 & 2 & 2 & 81 \\
\hline$\%$ & 8,6 & 26,0 & 24,7 & 21,0 & 11,1 & 3,7 & 2,4 & 2,4 & 100 \\
\hline
\end{tabular}

${ }^{272}$ Ensino superior de curta duração, de dois anos, que visa à formação profissional. 
8- Respostas do questionário

8.1- "Você acha que existe hierarquia na família?"

\begin{tabular}{|c|c|c|c|c|c|}
\hline & Sim & Não & Não sabe & s/inf. & Total \\
\hline No. & 48 & 26 & 4 & 3 & 81 \\
\hline$\%$ & 59,3 & 32,1 & 4,9 & 3,7 & 100 \\
\hline
\end{tabular}

8.2- "Considerando a hierarquia na família, enumere de acordo com a superioridade:"

\begin{tabular}{|c|c|c|c|c|c|c|c|}
\hline & $\mathbf{1}^{\mathbf{0}}$ & 2 & $3^{\circ}$ & $4^{\circ}$ & $5^{\circ}$. & s/inf. & total \\
\hline pai & 40 & 3 & 0 & 0 & 0 & 5 & 48 \\
\hline$\%$ & 83,3 & 6,3 & 0 & 0 & 0 & 10,4 & 100 \\
\hline mãe & 10 & 30 & 0 & 0 & 0 & 8 & 48 \\
\hline$\%$ & 20,8 & 62,5 & 0 & 0 & 0 & 16,7 & 100 \\
\hline irmão mais velho & 1 & 3 & 12 & 1 & 0 & 31 & 48 \\
\hline$\%$ & 2,0 & 6,3 & 25,0 & 2,0 & 0 & 64,7 & 100 \\
\hline irmã mais velha & 1 & 2 & 6 & 8 & 0 & 31 & 48 \\
\hline$\%$ & 2,0 & 4,0 & 12,5 & 16,7 & 0 & 64,8 & 100 \\
\hline $\begin{array}{l}\text { irmão ou irmã } \\
\text { mais novo ou } \\
\text { nova }\end{array}$ & 0 & 1 & 1 & 4 & 7 & 35 & 48 \\
\hline$\%$ & 0 & 2,0 & 2,0 & 8,3 & 14,6 & 73,1 & 100 \\
\hline
\end{tabular}

Resposta dos que preencheram o espaço "outros":

\begin{tabular}{|c|c|c|c|c|c|c|c|}
\hline & $1^{\circ}$. & $\mathbf{2}^{\mathbf{0}}$ & $3^{\circ}$. & $4^{\circ}$. & $5^{\circ}$. & s/inf. & total \\
\hline filha & 0 & 0 & 1 & 0 & 0 & 47 & 48 \\
\hline$\%$ & 0 & 0 & 2,0 & 0 & 0 & 98 & 100 \\
\hline avô & 1 & 0 & 0 & 0 & 0 & 47 & 48 \\
\hline$\%$ & 2,0 & 0 & 0 & 0 & 0 & 98 & 100 \\
\hline avó & 0 & 1 & 0 & 0 & 0 & 47 & 48 \\
\hline$\%$ & 0 & 2,0 & 0 & 0 & 0 & 98 & 100 \\
\hline nora & 0 & 0 & 1 & 0 & 0 & 47 & 48 \\
\hline$\%$ & 0 & 0 & 2,0 & 0 & 0 & 98 & 100 \\
\hline
\end{tabular}

\footnotetext{
273 Atividade exercida principalmente nos supermercados, por donas-de-casa que aproveitam o tempo ocioso, à tarde, para trabalhar e complementar a renda familiar.
} 
8.3- "Você acha que existe hierarquia no casal?"

\begin{tabular}{|c|c|c|c|c|c|}
\hline & Sim & Não & Não sabe & s/inf. & Total \\
\hline No. & 24 & 51 & 5 & 1 & 81 \\
\hline$\%$ & 29,6 & 63,0 & 6,1 & 1,2 & 100 \\
\hline
\end{tabular}

8.4- “(para quem respondeu "sim" na questão anterior) Quem você considera superior?"

\begin{tabular}{|c|c|c|c|c|c|c|}
\hline & marido & mulher & nenhum & não sabe & s/inf. & Total \\
\hline No. & 20 & 4 & 0 & 0 & 0 & 24 \\
\hline$\%$ & 83,3 & 16,7 & 0 & 0 & 0 & 100 \\
\hline
\end{tabular}

8.5- "Você considera que é impossível recusar o pedido dos pais?"

\begin{tabular}{|c|c|c|c|c|c|}
\hline & Sim & Não & Não sabe & s/inf. & Total \\
\hline No. & 32 & 40 & 8 & 1 & 81 \\
\hline$\%$ & 39,6 & 49,4 & 9,8 & 1,2 & 100 \\
\hline
\end{tabular}

8.6- "Dos itens abaixo, quando pedido pelos pais, qual você considera difícil de recusar?" (admite-se mais de uma resposta)

\begin{tabular}{|c|c|l|l|c|}
\hline $\begin{array}{l}\text { assuntos que } \\
\text { envolvem } \\
\text { dinheiro }\end{array}$ & $\begin{array}{l}\text { consulta sobre } \\
\text { questões íntimas }\end{array}$ & $\begin{array}{l}\text { resolução de } \\
\text { problemas }\end{array}$ & $\begin{array}{l}\text { questão de } \\
\text { relacionamento com } \\
\text { parentes etc. }\end{array}$ & outros \\
\hline 20 & 25 & 18 & 28 & 1 \\
\hline
\end{tabular}


8.7- "Você considera que é impossível recusar o pedido dos irmãos mais velhos?"

\begin{tabular}{|c|c|c|c|c|c|}
\hline & Sim & Não & Não sabe & s/inf. & Total \\
\hline No. & 11 & 46 & 12 & 12 & 81 \\
\hline$\%$ & 13,6 & 56,8 & 14,8 & 14,8 & 100 \\
\hline
\end{tabular}

8.8- "Dos itens abaixo, quando pedido pelos irmãos mais velhos, qual você considera difícil de recusar?” (admite-se mais de uma resposta)

\begin{tabular}{|c|c|l|c|c|}
\hline $\begin{array}{l}\text { assuntos que } \\
\text { envolvem } \\
\text { dinheiro }\end{array}$ & $\begin{array}{l}\text { consulta sobre } \\
\text { questões íntimas }\end{array}$ & $\begin{array}{l}\text { resolução de } \\
\text { problemas }\end{array}$ & $\begin{array}{l}\text { questão de relacionamento } \\
\text { com parentes etc. }\end{array}$ & outros \\
\hline 10 & 16 & 11 & 11 & 0 \\
\hline
\end{tabular}

8.9- "Você considera que é impossível recusar o pedido do superior de trabalho?"

\begin{tabular}{|c|c|c|c|c|c|}
\hline & Sim & Não & Não sabe & s/inf. & Total \\
\hline No. & 12 & 54 & 14 & 1 & 81 \\
\hline$\%$ & 14,8 & 66,7 & 17,3 & 1,2 & 100 \\
\hline
\end{tabular}

8.10- "Dos itens abaixo, quando pedido pelo superior de trabalho, qual você considera difícil de recusar?" (admite-se mais de uma resposta)

\begin{tabular}{|c|c|c|c|}
\hline assuntos de trabalho & assuntos particulares & assuntos que envolvem dinheiro & outros \\
\hline 20 & 5 & 3 & 0 \\
& & & \\
\hline
\end{tabular}

8.11- "Dos itens abaixo, qual você, na condição de superior de trabalho, pode pedir (ou já pediu) para seu subordinado?" (admite-se mais de uma resposta)

\begin{tabular}{|c|c|c|c|}
\hline assuntos de trabalho & assuntos particulares & assuntos que envolvem dinheiro & outros \\
\hline 70 & 13 & 0 & 1 \\
& & & \\
\hline
\end{tabular}


8.12- "Das definições abaixo sobre senpai ("veterano"), qual você considera mais adequado?"

\begin{tabular}{|l|c|c|l|c|c|c|c|}
\hline & $\begin{array}{l}\text { pessoa } \\
\text { mais } \\
\text { velha }\end{array}$ & $\begin{array}{l}\text { aquele que se } \\
\text { formou antes } \\
\text { (universidade ou } \\
\text { ensino médio) }\end{array}$ & $\begin{array}{l}\text { aquele que } \\
\text { ingressou na } \\
\text { empresa ou que } \\
\text { se empregou } \\
\text { antes }\end{array}$ & $\begin{array}{l}\text { aquele que tem } \\
\text { competência ou } \\
\text { técnica superior }\end{array}$ & outros & s/inf. & total \\
\hline No. & 32 & 6 & 23 & 8 & 2 & 10 & 81 \\
\hline$\%$ & 39,6 & 7,4 & 28,4 & 9,9 & 2,4 & 12,3 & 100 \\
\hline
\end{tabular}

8.13- "Você considera que é impossível recusar o pedido do senpai?"

\begin{tabular}{|c|c|c|c|c|c|}
\hline & Sim & Não & Não sabe & s/inf. & Total \\
\hline No. & 9 & 60 & 11 & 1 & 81 \\
\hline$\%$ & 11,1 & 74,1 & 13,6 & 1,2 & 100 \\
\hline
\end{tabular}

8.14- "Dos itens abaixo, quando pedido pelo senpai, qual você considera difícil de recusar?"

\begin{tabular}{|c|c|c|c|}
\hline assuntos que envolvem dinheiro & assuntos particulares & resolução de "encrencas" & outros \\
\hline 2 & 9 & 5 & 0 \\
& & & \\
\hline
\end{tabular}

8.15- "Dos itens abaixo, qual você, na condição de senpai, pode pedir (ou já pediu) para kôhai ("novato")?”

\begin{tabular}{|c|c|c|c|}
\hline assuntos que envolvem dinheiro & assuntos particulares & resolução de "encrencas" & outros \\
\hline 1 & 29 & 14 & 2 \\
\hline
\end{tabular}


8.16- "Considera que na sociedade japonesa, os homens ocupam posição superior?"

\begin{tabular}{|c|c|c|c|c|c|c|c|}
\hline & considero & $\begin{array}{c}\text { considero um } \\
\text { pouco }\end{array}$ & $\begin{array}{c}\text { não } \\
\text { considero }\end{array}$ & $\begin{array}{c}\text { não considero } \\
\text { em absoluto }\end{array}$ & não sei & s/inf. & Total \\
\hline No. & 27 & 30 & 19 & 3 & 0 & 2 & 81 \\
\hline$\%$ & 33,5 & 37 & 23,4 & 3,7 & 0 & 2,4 & 100 \\
\hline
\end{tabular}

8.17- "Considera que na sociedade japonesa, as mulheres ocupam posição superior?"

\begin{tabular}{|c|c|c|c|c|c|c|c|}
\hline & considero & $\begin{array}{c}\text { considero um } \\
\text { pouco }\end{array}$ & $\begin{array}{c}\text { não } \\
\text { considero }\end{array}$ & $\begin{array}{c}\text { não considero } \\
\text { em absoluto }\end{array}$ & não sei & s/inf. & Total \\
\hline No. & 1 & 2 & 60 & 15 & 1 & 2 & 81 \\
\hline$\%$ & 1,2 & 2,4 & 74,2 & 18,6 & 1,2 & 2,4 & 100 \\
\hline
\end{tabular}

8.18- "Considera que quem tem mais rendimento é superior a você?"

\begin{tabular}{|c|c|c|c|c|c|c|c|}
\hline & considero & $\begin{array}{c}\text { considero um } \\
\text { pouco }\end{array}$ & $\begin{array}{c}\text { não } \\
\text { considero }\end{array}$ & $\begin{array}{c}\text { não considero } \\
\text { em absoluto }\end{array}$ & não sei & s/inf. & Total \\
\hline No. & 0 & 3 & 52 & 25 & 0 & 1 & 81 \\
\hline$\%$ & 0 & 3,7 & 64,2 & 30,9 & 0 & 1,2 & 100 \\
\hline
\end{tabular}

8.19- "Considera que quem tem mais escolaridade é superior a você?"

\begin{tabular}{|c|c|c|c|c|c|c|c|}
\hline & considero & $\begin{array}{c}\text { considero um } \\
\text { pouco }\end{array}$ & $\begin{array}{c}\text { não } \\
\text { considero }\end{array}$ & $\begin{array}{c}\text { não considero } \\
\text { em absoluto }\end{array}$ & não sei & s/inf. & Total \\
\hline No. & 0 & 5 & 51 & 24 & 0 & 1 & 81 \\
\hline$\%$ & 0 & 6,2 & 63,0 & 29,6 & 0 & 1,2 & 100 \\
\hline
\end{tabular}

8.20- "Considera que quem ocupa posição social acima de você é superior a você?"

\begin{tabular}{|c|c|c|c|c|c|c|c|}
\hline & considero & $\begin{array}{c}\text { considero um } \\
\text { pouco }\end{array}$ & $\begin{array}{c}\text { não } \\
\text { considero }\end{array}$ & $\begin{array}{c}\text { não considero } \\
\text { em absoluto }\end{array}$ & não sei & s/inf. & Total \\
\hline No. & 11 & 21 & 32 & 13 & 1 & 3 & 81 \\
\hline$\%$ & 13,6 & 26,0 & 39,5 & 16,0 & 1,2 & 3,7 & 100 \\
\hline
\end{tabular}


8.21- "Considera que a relação interpessoal ao seu redor é de igualdade?"

\begin{tabular}{|c|c|c|c|c|c|c|c|}
\hline & considero & $\begin{array}{c}\text { considero um } \\
\text { pouco }\end{array}$ & $\begin{array}{c}\text { não } \\
\text { considero }\end{array}$ & $\begin{array}{c}\text { não considero } \\
\text { em absoluto }\end{array}$ & não sei & s/inf. & Total \\
\hline No. & 14 & 12 & 41 & 8 & 5 & 1 & 81 \\
\hline$\%$ & 17,3 & 14,8 & 50,7 & 9,8 & 6,2 & 1,2 & 100 \\
\hline
\end{tabular}

8.22- "Considera que a sociedade japonesa é hierarquizada (a hierarquia é considerada importante)?"

\begin{tabular}{|c|c|c|c|c|c|c|c|}
\hline & considero & $\begin{array}{c}\text { considero um } \\
\text { pouco }\end{array}$ & $\begin{array}{c}\text { não } \\
\text { considero }\end{array}$ & $\begin{array}{c}\text { não considero } \\
\text { em absoluto }\end{array}$ & não sei & s/inf. & Total \\
\hline No. & 41 & 32 & 7 & 0 & 0 & 1 & 81 \\
\hline$\%$ & 50,7 & 39,5 & 8,6 & 0 & 0 & 1,2 & 100 \\
\hline
\end{tabular}

8.23- "No que se refere às relações no trabalho, enumere na ordem que considera a hierarquia ser forte:"

\begin{tabular}{|c|c|c|c|c|c|}
\hline & $1^{\circ}$ & $2^{\circ}$ & $3^{\circ}$. & s/resp. & total \\
\hline $\begin{array}{l}\text { Relação superior- } \\
\text { subordinado }\end{array}$ & 68 & 8 & 1 & 4 & 81 \\
\hline$\%$ & 84,1 & 9,8 & 1,2 & 4,9 & 100 \\
\hline Rel. senpai-kôhai & 2 & 49 & 24 & 6 & 81 \\
\hline$\%$ & 2,4 & 60,5 & 29,7 & 7,4 & 100 \\
\hline $\begin{array}{l}\text { Ordenação pelo } \\
\text { desempenho } \\
\text { profissional }\end{array}$ & 6 & 20 & 45 & 10 & 81 \\
\hline$\%$ & 7,4 & 24,7 & 55,6 & 12,3 & 100 \\
\hline
\end{tabular}


8.24- "No que se refere às relações abaixo, enumere na ordem que considera a hierarquia ser forte:"

\begin{tabular}{|c|c|c|c|c|c|c|c|}
\hline & $1^{\circ}$. & $2^{\circ}$ & $3^{\circ}$ & $4^{\circ}$. & $5^{\circ}$ & s/resp. & total \\
\hline Relação pais-filho & 27 & 8 & 11 & 23 & 1 & 11 & 81 \\
\hline$\%$ & 33,5 & 9,8 & 13,6 & 28,3 & 1,2 & 13,6 & 100 \\
\hline $\begin{array}{l}\text { Relação entre } \\
\text { irmãos }\end{array}$ & 3 & 8 & 5 & 14 & 38 & 13 & 81 \\
\hline$\%$ & 3,7 & 9,8 & 6,2 & 17,3 & 47,0 & 16,0 & 100 \\
\hline $\begin{array}{l}\text { Relação superior- } \\
\text { subordinado }\end{array}$ & 42 & 19 & 7 & 3 & 2 & 8 & 81 \\
\hline$\%$ & 52,1 & 23,4 & 8,6 & 3,7 & 2,4 & 9,8 & 100 \\
\hline $\begin{array}{l}\text { Relação senpai- } \\
\text { kôhai }\end{array}$ & 1 & 32 & 18 & 14 & 6 & 10 & 81 \\
\hline$\%$ & 1,2 & 39,6 & 22,2 & 17,3 & 7,4 & 12,3 & 100 \\
\hline $\begin{array}{l}\text { Relação mais } \\
\text { velho-mais novo }\end{array}$ & 4 & 8 & 27 & 13 & 17 & 12 & 81 \\
\hline$\%$ & 4,9 & 9,8 & 33,5 & 16,0 & 21,0 & 14,8 & 100 \\
\hline
\end{tabular}

8.25- "Se se considerar hipoteticamente escalonar todos os japoneses do Japão hierarquicamente, quem deve ocupar a posição superior dentre todos?"

\begin{tabular}{|c|c|c|c|c|c|c|c|}
\hline & $\begin{array}{c}\text { Sem } \\
\text { resposta }\end{array}$ & Imperador & Outros & $\begin{array}{c}\text { Primeiro- } \\
\text { ministro }\end{array}$ & $\begin{array}{c}\text { Não } \\
\text { sabe }\end{array}$ & Ninguém & total \\
\hline No. & 24 & 22 & 13 & 11 & 6 & 5 & 81 \\
\hline$\%$ & 29,6 & 27,2 & 16,0 & 13,6 & 7,4 & 6,2 & 100 \\
\hline
\end{tabular}


8.26- "Por quê?"

8.26.1- Quem respondeu "Imperador":

\begin{tabular}{|l|c|c|}
\hline \multicolumn{1}{|c|}{ resposta } & No. & \% \\
\hline "porque é o símbolo do país" & 10 & 45,5 \\
\hline "tem autoridade ou privilégio" & 5 & 22,8 \\
\hline "porque é tradição, ou faz parte da história" & 4 & 18,2 \\
\hline "porque é o chefe de Estado" & 2 & 9,0 \\
\hline sem resposta & 1 & 4,5 \\
\hline Total & 22 & 100 \\
\hline
\end{tabular}

\subsection{2- Quem respondeu "Outros":}

\begin{tabular}{|c|c|c|c|}
\hline resposta & justificativa & No. & $\%$ \\
\hline \multirow[t]{3}{*}{ "os pais" } & "dependo deles"; "não existiria sem eles" & 3 & 23,0 \\
\hline & "são pessoas mais importantes" & 2 & 15,4 \\
\hline & "são conselheiros" & 1 & 7,7 \\
\hline \multirow[t]{2}{*}{ "pessoas mais velhas" } & "têm mais experiência de vida" & 1 & 7,7 \\
\hline & sem resposta & 1 & 7,7 \\
\hline "minha esposa" & "é a pessoa mais importante da minha vida" & 1 & 7,7 \\
\hline "os ricos" & "são eles que mandam" & 1 & 7,7 \\
\hline "o povo" & "não existe o país sem ele" & 1 & 7,7 \\
\hline "eu mesmo" & sem resposta & 1 & 7,7 \\
\hline \multirow[t]{2}{*}{ "um político $274 "$} & "ela tem carreira" & 1 & 7,7 \\
\hline & Total & 13 & 100 \\
\hline
\end{tabular}

${ }^{274}$ Na realidade, o informante citou o nome, mas será aqui omitido. 
8.26.3- Quem respondeu "Primeiro ministro":

\begin{tabular}{|l|c|c|}
\hline \multicolumn{1}{|c|}{ resposta } & No. & $\%$ \\
\hline $\begin{array}{l}\text { "porque é o líder do país"; "porque é o } \\
\text { número 1 da hierarquia" }\end{array}$ & 4 & 36,3 \\
\hline "porque define as políticas, manda" & 3 & 27,3 \\
\hline "porque é o representante do povo" & 2 & 18,2 \\
\hline "porque não vejo alternativa" & 2 & 18,2 \\
\hline Total & 11 & 100 \\
\hline
\end{tabular}


Apêndice 


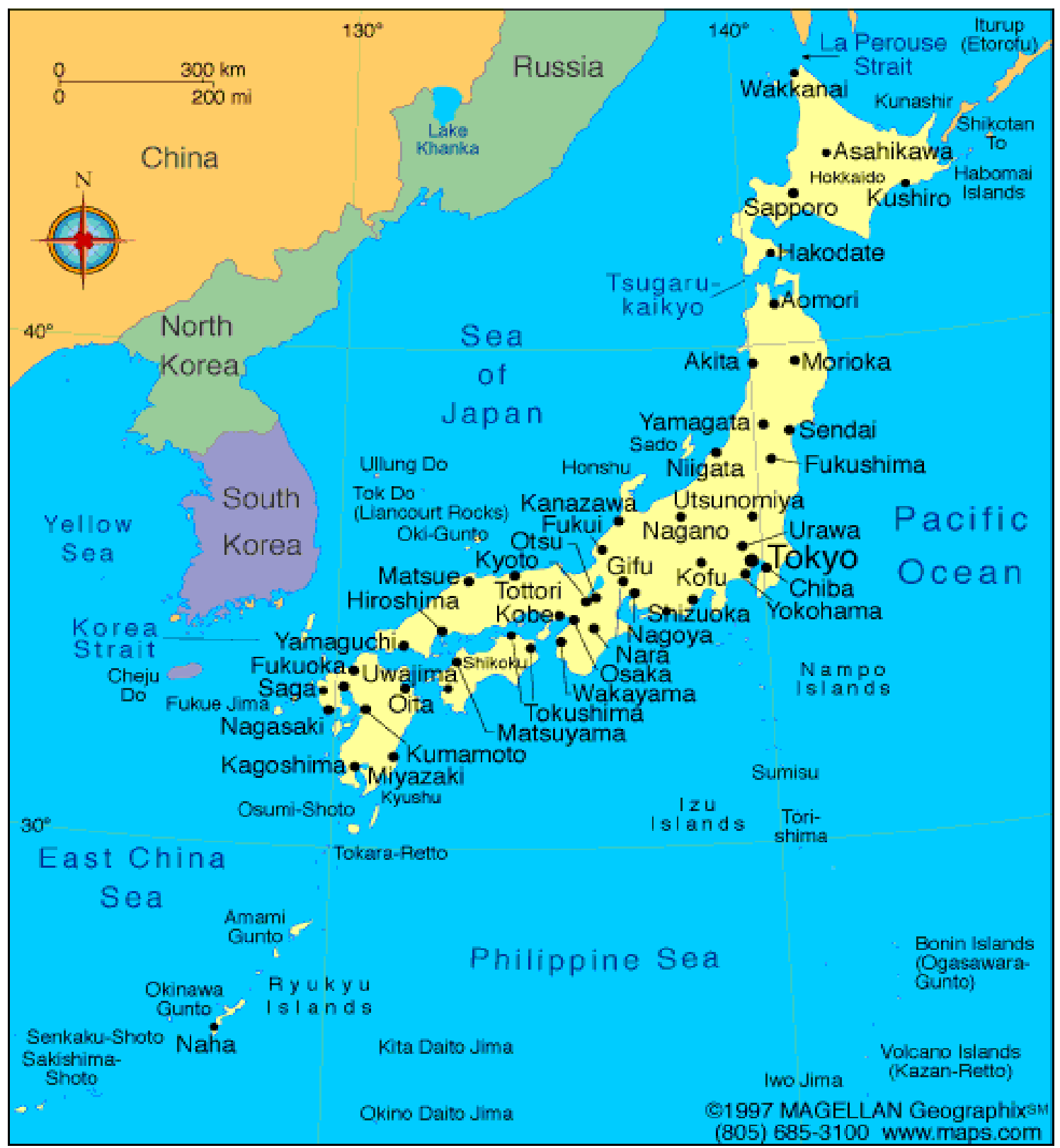

Fonte: http://viagenslacoste.blogspot.com/2011/12/mapa-do-japao-japan-map-outrosmapas.html 